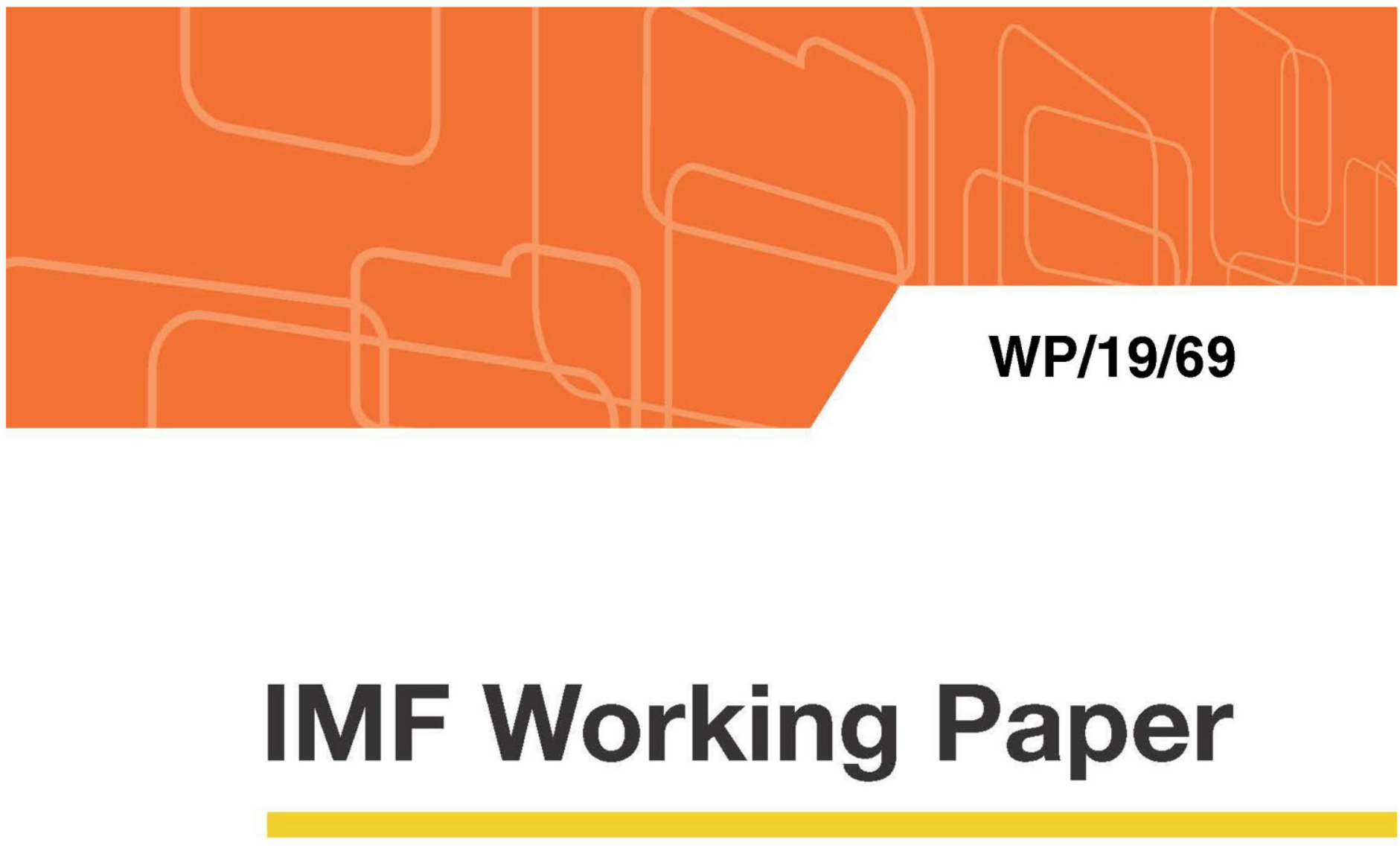

\title{
Costs of Sovereign Defaults: Restructuring Strategies, Bank Distress and the Capital Inflow-Credit Channel
}

by Tamon Asonuma, Marcos Chamon, Aitor Erce, and Akira Sasahara

MF Working Papers describe research in progress by the author(s) and are published to elicit comments and to encourage debate. The views expressed in IMF Working Papers are those of the author(s) and do not necessarily represent the views of the IMF, its Executive Board, or IMF management. 


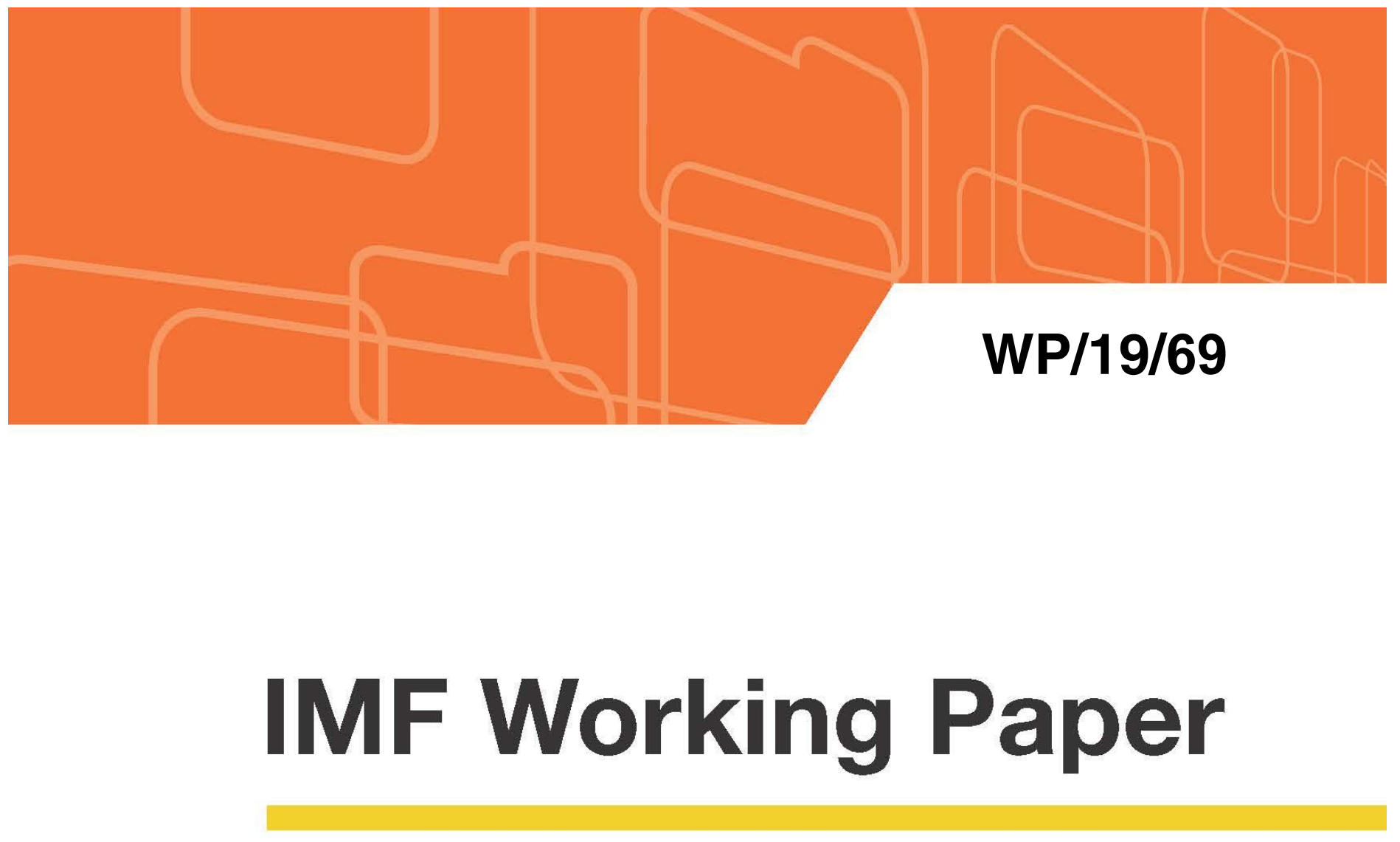

\section{Costs of Sovereign Defaults: Restructuring Strategies, Bank Distress and the Capital Inflow-Credit Channel}

by Tamon Asonuma, Marcos Chamon, Aitor Erce, and Akira Sasahara

MF Working Papers describe research in progress by the author(s) and are published to elicit comments and to encourage debate. The views expressed in IMF Working Papers are those of the author(s) and do not necessarily represent the views of the IMF, its Executive Board, or IMF management.

I N T E R N A T I O N A L M O 


\title{
IMF Working Paper
}

Research Department and Strategy Policy and Review Department

\section{Costs of Sovereign Defaults: Restructuring Strategies, Bank Distress and the Capital Inflow-Credit Channel}

\author{
Prepared by Tamon Asonuma, Marcos Chamon, Aitor Erce, and Akira Sasahara*
}

Authorized for distribution by Jonathan D. Ostry and Mark Flanagan

March 2019

\section{This Working Paper should not be reported as representing the views of the IMF.}

The views expressed in this Working Paper are those of the author(s) and do not necessarily represent those of the IMF or IMF policy. Working Papers describe research in progress by the author(s) and are published to elicit comments and to further debate.

\begin{abstract}
Sovereign debt restructurings are associated with declines in GDP, investment, bank credit, and capital flows. The transmission channels and associated output and banking sector costs depend on whether the restructuring takes place preemptively, without missing payments to creditors, or whether it takes place after a default has occurred. Post-default restructurings are associated with larger declines in bank credit, an increase in lending interest rates, and a higher likelihood of triggering a banking crisis than pre-emptive restructurings. Our local projection estimates show large declines in GDP, investment, and credit amplified by severe sudden stops and transmitted through a "capital inflow-credit channel".
\end{abstract}

JEL Classification Numbers: F34; F41; H63.

Keywords: Sovereign Debt; Sovereign Defaults; Sovereign Debt Restructurings; GDP Growth; Investment; Banking Crisis; Local Projection

Author's E-mail Address: TAsonuma@imf.org; MChamon@imf.org; a.erce@esm.europa.eu; sasahara@uidaho.edu

\footnotetext{
* Tamon Asonuma is an economist in the Strategy Policy and Review Department. Marcos Chamon is a deputy division chief in the Research Department. Aitor Erce is a principal economist at the European Stability Mechanism. Akira Sasahara is an assistant professor at University of Idaho. The authors thank Kosuke Aoki, Suman Sambha Basu, Tamim Bayoumi, Francesca Gaia Caselli, Anusha Chari, Flavia Corneli, Xavier Debrun, Giovanni Dell'Ariccia, Raphael Andre Espinoza, Michal Fabinger, Johannes Fleck (discussant), Victor Gaspar, Grey Gordon, Nils Gornemann, Yuriy Gorodnichenko, Yuko Hashimoto, Graciela Kaminsky, Sebnem Kalemli-Özcan, Leonard Martinez, Carlos Mulas-Granado, Tomoyuki Nakajima, Maurice Obstfeld, Óscar Jordá, Jonathan D. Ostry, Mahvash Saeed Qureshi, Alan M. Taylor, Dominike Thaler, Christoph Trebesch, Juergen Von Hagen, Alejandro M. Werner, and Jeromin Zettlemeyer (discussant) as well as seminar participants at ADEMU "Fiscal Risk and Public Sector Balance Sheets" (Bonn), ESM, IMF (FAD, Surveillance Meetings, WHD), IMF RES SID “Too Many Objectives or Too Few Instruments? Economic Policy Challenges Ten Years After the Crisis" Workshop, Kyoto University, LACEA-LAMES (Guayaquil), Spanish Economic Association (Barcelona), Summer Workshop on Economic Theory (Hokkaido University), and University of Tokyo for comments and suggestions. We would also like to thank Manzoor Ahmed Gill for research assistance and Chifundo Moya for editorial assistance.
} 
I. Introduction

II. New Stylized Facts on Sovereign Debt Restructurings, Banking Crises, Severe Credit and Capital Inflow Declines

A. Data on Sovereign Debt Restructurings, Banking Crises, Severe Credit and Capital Inflow Declines

B. Stylized Facts on GDP, Investment, Private Credit, and Capital Flows in Sovereign Debt Restructurings ... .14

C. Data on Macroeconomic Variables . $\underline{16}$

D. Time Sample

III. Local Projection Approach

A. Endogeneity of Debt Restructuring Decisions............................................. 17

B. Augmented Inverse Probability Weighted (AIPW) Estimation ............................ 21

C. Role of Capital Inflow-Credit Channel ............................................................. 25

D. Duration, Haircuts, and Missed Payments ......................................................29

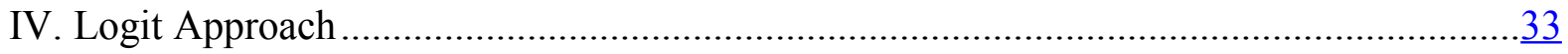

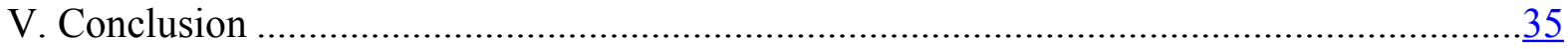

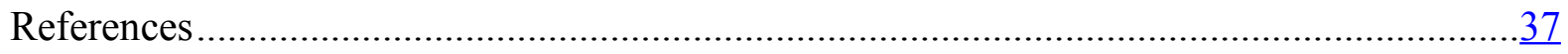

Tables

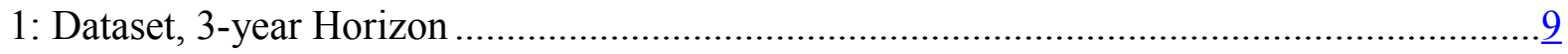

2: Characteristics of the Treatment and Control Groups …........................................... 18

3: Predicting the Start of Debt Restructurings, Probit ....................................................

4: Predicting Duration and Haircuts, Poisson .............................................................

5: Banking Crises and Severe Credit and Net Capital Inflow Declines after Debt .................

Figures

1: Debt Restructurings, Severe Credit Declines and Protracted Net Capital Inflow Declines,

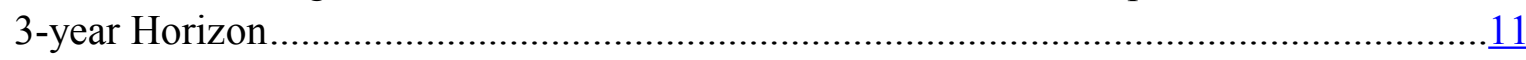

2: Debt Restructurings and Banking Crises .................................................................12

3: Debt Restructurings, Severe Credit and Net Capital Inflow Declines, 3-year Horizon .......14

4: GDP and Investment around Debt Restructurings, Average ......................................15

5: Private Credit, Lending Interest Rates, and Capital Flows around Debt Restructurings,

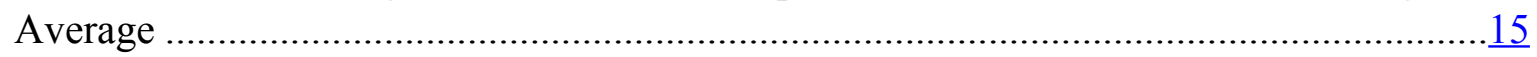

6: Classification Power of the First Stage Regressors …............................................. 20

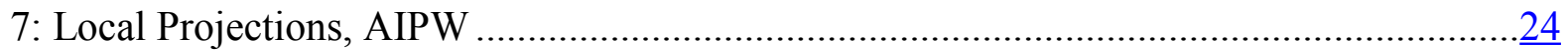

8: Private Credit, Investment, and GDP around Debt Restructurings, with/without Severe

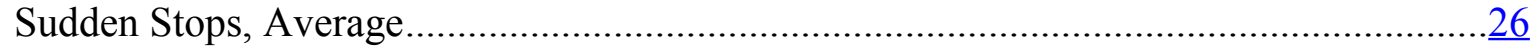


9: Restructurings with/without Severe Sudden Stops, AIPW ......................................28

6: Restructurings with/without Credit Crunches or Sudden Stops, AIPW .......................... 28

10: GDP around Debt Restructurings with Short Duration and/or Small Haircuts, Average..29

11: GDP after Post-default Restructurings, AIPW

Appendices

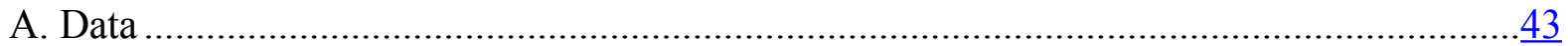

B. Further Empirical Analysis — Support for Stylized Facts …..................................... 50

C. Estimation Results from Local Projections .......................................................... 51

D. Further Regression Results - Support for Main Results ............................................ $\underline{56}$

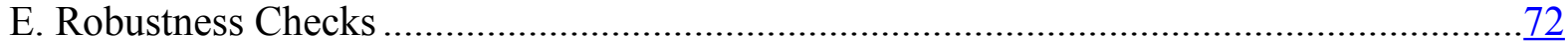




\section{INTRODUCTION}

Countries where public debt is restructured tend to experience declines in GDP, investment, and private sector credit (Sturzenegger 2004; Borensztein and Panizza 2009). Though previous studies have provided different measures of output and banking sector costs during restructurings, little is known about the transmission channels of debt restructuring to the financial system and the broader economy. This is a remarkable gap, with real world implications for sovereign debtors facing the problem of how to restructure their debt. As evidenced by the recent sovereign debt workouts in Jamaica (2010, 2013) or Cyprus (2013), understanding the spillovers and feedback effects that a debt restructuring has through the domestic financial system can help design the restructuring so as to minimize the risk that it leads to a full blown banking crisis.

This paper contributes to that goal by shedding light on how the transmission channels and associated output and banking sector costs of debt restructurings differ depending on the restructuring strategy followed. We classify restructuring strategies as in Asonuma and Trebesch (2016), based on whether payments were missed (post-default debt restructuring), were missed but only temporarily and with the consent of the foreign creditors (weakly pre-emptive debt restructuring) or whether payments continued to be made in full and on time during the negotiations (strictly pre-emptive debt restructuring).

We use local projection models_ — originally proposed by Jordà (2005) — — to quantify the overall cumulative effect (both direct and indirect) of the restructuring strategy over a long horizon, while controlling for the dynamic feedback from other variables. Our analysis is based on a sample of 70 countries with at least one sovereign debt restructuring over 1978-2010 and covers: (i) 179 restructurings of privately-held external sovereign debt, (ii) 39 banking crises, (iii) 48 severe credit declines, and (iv) 40 severe protracted declines in net capital inflow. Our estimates show that post-default restructurings are associated with the most severe and protracted declines in GDP and investment (in percent of GDP), with cumulative contractions of 4 and 1 percentage points over the first 3 years, respectively. These restructurings are also associated with severe and prolonged declines in bank credit, and sharp increases in lending interest rates. In contrast, pre-emptive restructuring events have much milder and short-lived declines in GDP, investment, private credit, and net capital inflows. The intensity of the effects of weakly preemptive restructurings falls between those of post-default and strictly preemptive restructurings. The sharper contractions in bank credit, and the associated worse lending terms, seem at the root of the severe and prolonged declines in GDP and investment in post-default restructurings. Furthermore, the deterioration of the banking sector is also confirmed by logit estimates that show countries undergoing post-default restructurings are significantly more likely to experience a banking crisis than those following a preemptive restructuring. We confirm the key role of the capital inflow-credit channel by estimating local projections on subsamples of three restructuring strategies with and without subsequent severe sudden stops - allowing the responses to vary

\footnotetext{
${ }^{1}$ See also Jordà and Taylor (2016), Angrist et al. (2016), and Auerbach and Gorodnichenko (2016).
} 
depending on the state of the economy as in Auerbach and Gorodnichenko (2016) and Jordà and Taylor (2016). ${ }^{2}$ Severe sudden stops are defined as events where there is a severe contraction in net capital inflows. They are strongly associated with credit crunches. Both of them are more likely to occur, and are more severe when they do, following post-default restructurings. ${ }^{3}$ Severe sudden stops and credit crunches are associated with the worst contractions in investment (in percent of GDP) and GDP (with cumulative declines of 4 and 5 percentage points of GDP over 2 years after a severe sudden stop occurs). This prominent "capital inflow-credit channel" influences GDP directly and indirectly through private credit and investment and its feedback effects, driving the larger impact that post-default restructurings have on GDP and investment.

A country's decision of how to go about restructuring its debt is influenced by the economic conditions it faces. ${ }^{4}$ Thus, Ordinary Least Square (OLS) estimation suffers from endogeneity problems. To address this issue, our baseline results follow the convention in the literature and apply the Augmented Inverse Probability Weighted (AIPW) estimator (Jordà et al., 2013) when using the local projections. ${ }^{5}$ This method assigns a greater weight to observations that are less likely to be associated with an event, aiming to replicate a distribution without selection bias.

The complex linkages and feedback channels between the real, financial, and public sectors we document shape the response to a debt restructuring. Our results suggest much of the adverse costs depend on whether a severe sudden stop can be avoided, which is more likely in preemptive restructurings. However, we must bear in mind that countries face several different constraints on the choice of how to restructure. These include not only economic and political constraints, but also the possibility that a large adverse shock suddenly places the country in a "bad equilibrium" (e.g., Cole and Kehoe 2000). That can leave the country no choice but to stop servicing the debt. Even when payments are missed (post-default episodes), output costs of restructurings are to some extent mitigated depending on the negotiation process and speed of settlement. ${ }^{6}$ The output costs of post-default episodes with short duration or small haircuts are lower than those with long duration or high haircuts, but still higher than the ones for weakly preemptive restructurings. This suggests that much of the benefits stem from avoiding missing payments rather than creditor friendly terms per se.

\footnotetext{
${ }^{2}$ We use the information set available at the time of the restructuring to predict whether a sudden stop will take place (so as to avoid using ex post information in the local projections).

${ }^{3}$ See Broner et al. (2013), Reinhart et al. (2016), Kaminsky and Vega-García (2016), and Arteta and Hale (2008) for capital flows and sovereign debt crises.

${ }^{4}$ See Asonuma and Trebesch (2016) for empirical and theoretical findings on the choice of restructuring strategies.

${ }^{5}$ Our AIPW estimator falls into the broad class of 'doubly robust' estimators (Robins et al. 1994). The 'doubly robust' property means that consistency of the estimated average treatment effect (ATE) can be proved in the special cases where either the propensity score model and/or the conditional mean is correctly specified; Monte Carlo evidence also suggests that the estimator performs better than alternatives even in more general cases too.

${ }^{6}$ Our finding on smaller output costs in post-default restructurings with small haircuts is in line with Trebesch and Zabel (2017) _ “soft defaults" classified by both government's behavior (coerciveness) and haircuts — and Marchesi (2016).
} 
This paper contributes to various literature strands. First and foremost, it adds to the large literature on the output costs of sovereign defaults, e.g., Sturzenegger (2004), Tomz and Wright (2007), Borensztein and Panizza (2009), De Paoli et al. (2009), Levy-Yeyati and Panizza (2011), Asonuma and Trebesch (2016), Trebesch and Zabel (2017), and Kuvshinov and Zimmermann (2016). ${ }^{7,8}$ These papers provide different measures of output costs by applying conventional panel regressions and local projection approaches. Our contribution to that literature is to show that the output costs over the longer horizon depend crucially on the restructuring strategy adopted. Moreover, we highlight the transmission channels through which a debt restructuring generates the output losses, while many of the papers above do not.

Our findings also contribute to the literature on the nexus between sovereign and banking crises in emerging economies. ${ }^{9}$ The existing evidence on the direction of causality between sovereign and banking crises remains mixed. Borensztein and Panizza (2009) show that default episodes seem to cause banking crises, while Reinhart and Rogoff (2011b) find that banking crises tend to precede sovereign debt crises. Balteanu and Erce (2018) reconcile these papers by exploring the twoway determinants of "twin" banking and sovereign crises simultaneously. Our main contribution is to provide new evidence on the linkage across debt restructurings, severe sudden stops, and credit crunches, showing that the likelihood of a banking crisis depends on the nature of the restructuring.

Finally, we also contribute to a growing literature that studies how debt restructurings can be designed to more likely achieve better outcomes. These aspects have been studied by IMF (2014, 2015), Brookings-CIEPR (2013), Fernandez and Martin (2014), and Mariscal et al., (2015) among others. ${ }^{10}$ Most papers contrast outcomes of "reprofilings" (restructurings that mostly involve an extension of payment terms) to those of restructurings that involve deeper haircuts on different measures of borrower and creditor welfare (e.g., growth performance, incidence of future debt crises, return to market access, among others). Our paper highlights that much of the adverse costs hinge on whether restructurings take place pre-emptively, and also sheds light on the particular financial sector linkages that are associated with avoiding the worst outcomes. Our empirical results highlight a channel of transmission of sovereign default into the real economy that is not prominent in recent theoretical work on output dynamics, which has focused on how restructuring domestic debt can affect credit through the banks' exposure to sovereign debt (e.g.,

\footnotetext{
${ }^{7}$ See also Forni et al. (2016) and Furceri and Zdzienicka (2012).

${ }^{8}$ Theoretical literature explores endogenous output costs through trade channel (Mendoza and Yue 2012) and through investment channel (Gordon and Guerron-Quintana 2018; Park 2017; Gornemann 2015).

${ }^{9}$ For further empirical studies, see Gennaioli et al. (2018), Jordà et al. (2016), Acharya et al. (2015), and Sandleris and Wright (2014). For recent studies on specific debt restructuring episodes using micro data, see Hébert and Schreger (2017), Chari et al. (2018), and Fakos et al. (2018).

${ }^{10}$ For restructuring strategies, see Sturzenegger and Zettelmeyer (2006), Diaz-Casssou et al. (2008), Panizza et al. (2009), Das et al. (2012), Erce (2014), Asonuma and Trebesch (2016), and Asonuma et al. (2016).
} 
Gennaioli et al., 2014; Sosa-Padilla 2018). ${ }^{11}$ Our analysis shows that even restructurings of external debt - not held by domestic banks - can have deleterious effects amplified through the capital inflow-credit channel (potentially due to loss in banks' access to external financing following the sovereigns' loss of market access). ${ }^{12}$

The rest of the paper is structured as follows. In the next section, we explain our dataset and document stylized facts regarding the response of GDP, investment, bank lending, and net capital flows to different debt restructuring strategies. Section III explains the local projection approach and presents our results, including estimations based on sub-sampling our restructuring events to identify the "capital inflow-credit channel". Section IV introduces our logit model approach and discusses the results. Finally, Section V concludes. Details of various robustness analysis are provided in the Appendix.

\section{New Stylized Facts on Sovereign Debt Restructurings, Banking Crises, SEVERE CREDIT AND CAPITAL INFLOW DECLINES}

\section{A. Data on Sovereign Debt Restructurings, Banking Crises, Severe Credit and Capital Inflow Declines}

Throughout the paper, we focus only on private external debt restructurings, so neither official external debt nor domestic debt restructurings are considered-as a robustness check, we consider private external debt restructurings with and without official external debt (Paris Club) restructurings or IMF-supported programs, and single external debt restructurings in Appendix E.3 and E. $4 .{ }^{13}$

Asonuma and Trebesch (2016) classify debt restructurings on private external debt as follows: ${ }^{14}$

○ Definition i. 'Strictly preemptive restructurings' are those which are implemented without missing any payments at all (no legal default).

o Definition ii. 'Weakly preemptive restructurings' are those in which some payments are missed, but only temporarily and after the start of formal or informal negotiations with creditor representatives (no unilateral default).

\footnotetext{
${ }^{11}$ See also Bocola (2016), Arellano et al. (2017), Engler and Große Steffen (2016), Bolton and Jeanne (2011), Perez (2016), Pei (2016), and Mallucci (2015).

12 Sandleris (2014) theoretically shows that even if domestic agents do not hold government bonds, a sovereign default can create a credit crunch in domestic credit markets and a contraction in foreign lending to the private sector.

${ }^{13}$ See Das et al. (2012), Cheng et al. (2018), and Marchesi (2016) for work on official external debt restructurings, Reinhart and Rogoff (2011a) and Erce and Mallucci (2018) for work on restructurings involving domestic debt.

14 Their classification of the nature of the restructuring strategy is only made after its completion.
} 
○ Definition iii. 'Post-default restructurings' are all other cases, in which payments are missed unilaterally and without the agreement of creditor representatives (unilateral default prior to negotiations).

Our dataset of 179 restructurings over 1978-2010 is coded accordingly and summarized in Panel A of Table $1 .{ }^{15}$ The details of countries experiencing restructurings are summarized in Appendix A.1. Average restructuring duration and haircuts vary substantially across strategies: 5.0, 1.1, and 0.9 years on average for duration of post-default, weakly preemptive, and strictly preemptive restructurings, respectively and 48.0, 18.2, and 18.9 percent on average for haircuts of postdefault, weakly preemptive, and strictly preemptive episodes, respectively. We code the restructuring strategy dummies at an annual frequency, setting it to 1 if it either starts in the current year or continues from the previous year, and 0 otherwise. For comparison with previous studies, we also use sovereign defaults from Standard and Poor's (S\&P) database for robustness check in Appendix E.2 though its coverage is a subset of the restructuring episodes of Asonuma and Trebesch (2016).

Laeven and Valencia (2013) define a banking crisis as an event that meets two conditions. First, there are significant signs of financial distress in the banking system (as indicated by significant bank runs or losses in the banking system). Second, there must be significant intervention measures in response to losses in the banking system. Over the same period (1978-2010), they document 39 banking crises - last 3.3 years on average - occurring within the 3 years since the start of 127 debt restructurings as reported in the 1 st column in Panel B in Table $1 .{ }^{16}$ As the data are at an annual frequency, we set our banking crisis dummy as 1 if a banking crisis occurs or continues in that year and 0 otherwise.

\section{- Stylized fact 1: Severe declines in credit and net capital inflows occur simultaneously with sovereign debt restructurings.}

\footnotetext{
${ }^{15}$ Asonuma and Trebesch (2016) define the start of a restructuring process as the default month and/or month in which a distressed restructuring is announced, and the end of a restructuring as the month of the final agreement and/or the implementation of the debt exchange. They also provide the duration of all episodes at a monthly frequency.

${ }^{16}$ Leaven and Valencia (2013) also code the duration of banking crisis at an annual frequency.
} 
Table 1: Dataset, 3-year Horizon

Panel A: Debt Restructuring Sample

\begin{tabular}{rccc}
\hline & Post-default & Weakly preemptive & Strictly preemptive \\
\hline \# of episodes & 111 & 45 & 23 \\
\# of countries & 60 & 26 & 13 \\
Average duration (years) & 5.0 & 1.1 & 0.9 \\
Average haircuts (percent) & 48.0 & 18.2 & 18.9 \\
\hline Representative episodes & Argentina 2001-05, & Ukraine & Pakistan \\
in 1999-2010 & Russia 1998-2000 & (Global Exch.) 2000, & (Ext. bonds) 1999, \\
& & Belize 2006-07 & Uruguay 2003 \\
\hline
\end{tabular}

\begin{tabular}{|c|c|c|c|c|c|}
\hline \multicolumn{6}{|c|}{ Panel B: Banking Crisis Sample 2/ } \\
\hline & $\begin{array}{c}\text { All debt } \\
\text { restructurings }\end{array}$ & $\begin{array}{c}\text { Post- } \\
\text { default }\end{array}$ & $\begin{array}{c}\text { Weakly } \\
\text { preemptive }\end{array}$ & Strictly preemptive & $\begin{array}{c}\text { All obs. } \\
1 /\end{array}$ \\
\hline \# of available episodes & 127 & 91 & 39 & 21 & 1,126 \\
\hline \# of banking crises & 39 & 30 & 7 & 2 & 71 \\
\hline Conditional probability & $30.7 \%$ & $33.0 \%$ & $17.9 \%$ & $9.5 \%$ & $6.3 \%$ \\
\hline Representative episodes & & Argentina 2001-05 & Turkey 1981 & Algeria 1990 & \\
\hline in $1999-2010$ & & Russia 1998-2000 & Niger 1983 & Ukraine 1998 & \\
\hline \multicolumn{6}{|c|}{ Panel C: Severe Credit Declines 3/ 6/ } \\
\hline & $\begin{array}{c}\text { All debt } \\
\text { restructurings }\end{array}$ & $\begin{array}{c}\text { Post- } \\
\text { default }\end{array}$ & $\begin{array}{c}\text { Weakly } \\
\text { preemptive }\end{array}$ & Strictly preemptive & $\begin{array}{c}\text { All obs. } \\
1 /\end{array}$ \\
\hline \# of available episodes & 107 & 73 & 26 & 8 & 1,433 \\
\hline \# of severe credit declines & 48 & 36 & 10 & 2 & 308 \\
\hline Conditional probability & $44.9 \%$ & $49.3 \%$ & $38.5 \%$ & $25.0 \%$ & $21.5 \%$ \\
\hline Representative episodes & & $\begin{array}{c}\text { Turkey } 1976 \\
\text { Togo } 1991\end{array}$ & $\begin{array}{c}\text { Brazil } 1983 \\
\text { Venezuela } 1986\end{array}$ & $\begin{array}{c}\text { Algeria } 1990 \\
\text { Uruguay } 2003\end{array}$ & \\
\hline \multicolumn{6}{|c|}{ Panel D: Severe Protracted Net Capital Inflow Declines (Sum) 4/ 6/ } \\
\hline & $\begin{array}{c}\text { All debt } \\
\text { restructurings }\end{array}$ & $\begin{array}{c}\text { Post- } \\
\text { default }\end{array}$ & $\begin{array}{c}\text { Weakly } \\
\text { preemptive }\end{array}$ & Strictly preemptive & $\begin{array}{c}\text { All obs. } \\
1 /\end{array}$ \\
\hline$\#$ of available episodes & 113 & 77 & 26 & 10 & 1,178 \\
\hline \# of severe net cap. inf. dec. & 40 & 29 & 9 & 2 & 303 \\
\hline Conditional probability & $35.4 \%$ & $37.7 \%$ & $34.6 \%$ & $20.0 \%$ & $25.7 \%$ \\
\hline Representative episodes & & $\begin{array}{c}\text { Costa Rica } 1981 \\
\text { Moldova } 2001\end{array}$ & $\begin{array}{l}\text { Brazil } 1982 \\
\text { Belize } 2006\end{array}$ & Ukraine 1998 & \\
\hline \multicolumn{6}{|c|}{ Panel E: Severe Protracted Net Capital Inflow Declines (Difference) 5/ 6/ } \\
\hline & $\begin{array}{c}\text { All debt } \\
\text { restructurings }\end{array}$ & $\begin{array}{c}\text { Post- } \\
\text { default }\end{array}$ & $\begin{array}{c}\text { Weakly } \\
\text { preemptive }\end{array}$ & Strictly preemptive & $\begin{array}{c}\text { All obs. } \\
1 /\end{array}$ \\
\hline \# of available episodes & 113 & 77 & 26 & 10 & 1,178 \\
\hline \# of severe net cap. inf. dec. & 40 & 25 & 8 & 1 & 303 \\
\hline Conditional probability & $35.4 \%$ & $32.5 \%$ & $30.8 \%$ & $10.0 \%$ & $25.7 \%$ \\
\hline
\end{tabular}

Notes: $1 /$ Including episodes in countries without any experience of private external debt restructurings.

2/ Banking crises over three years since the start of debt restructurings, from year $t+1$ to $t+3$.

3 / Severe credit declines are defined as observations with the cumulative percentage point difference in the credit-to-GDP ratio over three years, $d_{i, t+3}^{C}=100 \times\left(\right.$ Credit $_{i, t+3} / G D P_{i, t+3}-$ Credit $\left._{i, t} / G D P_{i, t}\right)$, is less than the 25 th percentile of the distribution.

4/ Severe protracted net capital inflow declines (sum) are defined as observations where the sum of cumulative percentage point

differences in the net capital inflows-to-GDP ratio over three years, $d_{t+3}^{N C I, S U M}=100 \times \sum_{s=1}^{3}\left(N C I_{i, t+s} / G D P_{i, t+s}-N C I_{i, t} / G D P_{i, t}\right)$, is less than

the 25th percentile of the distribution.

5/ Severe protracted net capital inflow declines (difference) are defined as observations where the cumulative percentage point difference in the net capital inflows-to-GDP ratio over three years, $d_{t+3}^{N C I, D I F}=100 \times\left(N C I_{i, t+3} / G D P_{i, t+3}-N C I_{i, t} / G D P_{i, t}\right)$, is less than the 25 th percentile of the distribution.

6/ The sample after 2008 is dropped because macroeconomic variables in the period are largely influenced by the Global Financial Crisis. Debt restructuring episodes with more than one strategy within a window of $[-2,+3]$ years around the start year of a debt restructuring $t=0$ are coded with the worst strategy only. 
Moreover, in line with conventions in the literature (Bernanke and Cara 1999; Calvo et al. 1996; Kaminsky and Reinhart 1999), we define both severe credit declines and protracted net capital inflow declines - the conventional thresholds of 25 th percentile applied symmetrically across observations with or without any types of debt restructurings as reported in Tables A2 and A3 in Appendix A.3-as follows:

- Definition iv. A 'severe credit decline' is an event where the cumulative percentage point difference in the credit-to-GDP ratio over three or five years, $d_{i, t+s}^{C}=$ $100 \times\left(\right.$ Credit $_{i, t+s} / G D P_{i, t+s}-$ Credit $\left._{i, t} / G D P_{i, t}\right)$, for $s=3,5$, is less than the 25 th percentile of the distribution. ${ }^{17}$

- Definition v. A 'severe protracted net capital inflow decline' is an event where (a) the sum of cumulative percentage point differences in the net capital inflows-to-GDP ratio over three or five years, $d_{i, t+r}^{N C I, S U M}=100 \times \sum_{s=1}^{r}\left(N C I_{i, t+s} / G D P_{i, t+s}-N C I_{i, t} / G D P_{i, t}\right)$ for $r=3,5$, is less than the 25 th percentile of the distribution, or (b) the cumulative percentage point difference in the net capital inflows-to-GDP ratio over three or five years, $d_{i, t+r}^{N C I, D I F}=100 \times\left(N C I_{i, t+r} / G D P_{i, t+r}-N C I_{i, t} / G D P_{i, t}\right)$ for $r=3,5$, is less than the 25 th percentile of the distribution, respectively.

Over the same period (1978-2010), we document 48 severe credit declines and 40 (34) severe protracted net capital inflow declines occur simultaneously with (or follow) sequentially debt restructurings as reported in column 1 in Panels C, D, and E in Table 1. In comparison, 49 and 35 (32) episodes are identified, respectively under 5-year criterion as reported in Panels C, D, and E in Table A4 in Appendix A.4. Using the same approach, we set our severe credit decline dummy (severe net capital inflow decline dummy) as 1 if a severe credit decline (protracted net capital inflow decline) occurs or continues in that year and 0 otherwise.

To illustrate occurrence of these events across countries and time, Figure 1 shows debt restructurings and severe declines in credit and net capital inflows over our sample. One pattern of events emerges from Figure 1 is that severe declines in credit and net capital inflows occur simultaneously with or follow sequentially debt restructurings. Previous studies explore these links, but only between two out of three events separately: Reinhart and Rogoff (2009) and Reinhart et al. (2016) document the link between debt restructurings (sovereign defaults) and severe declines in net capital inflows, and Cesa-Bianchi et al. (2018) find the link between severe net capital inflow declines and severe credit declines.

\footnotetext{
${ }^{17}$ Bernanke and Lown (1991) define a bank credit crunch as a significant leftward shift in the supply curve for bank loans, holding both the safe real interest rate and the quality of potential borrowers. Clair and Tucker (1993) further define it as a curtailment of the credit supply in response to both (i) a decline in the value of bank capital and (ii) conditions imposed by regulators, bank supervisors, or banks themselves that require banks to hold more capital than they previously would have held.
} 
- Stylized fact 2: Banking crises, and severe credit and net capital inflow declines occur more frequently following post-default restructurings.

Figure 1: Debt Restructurings, Severe Credit Declines and Protracted Net Capital Inflow Declines, 3-year Horizon

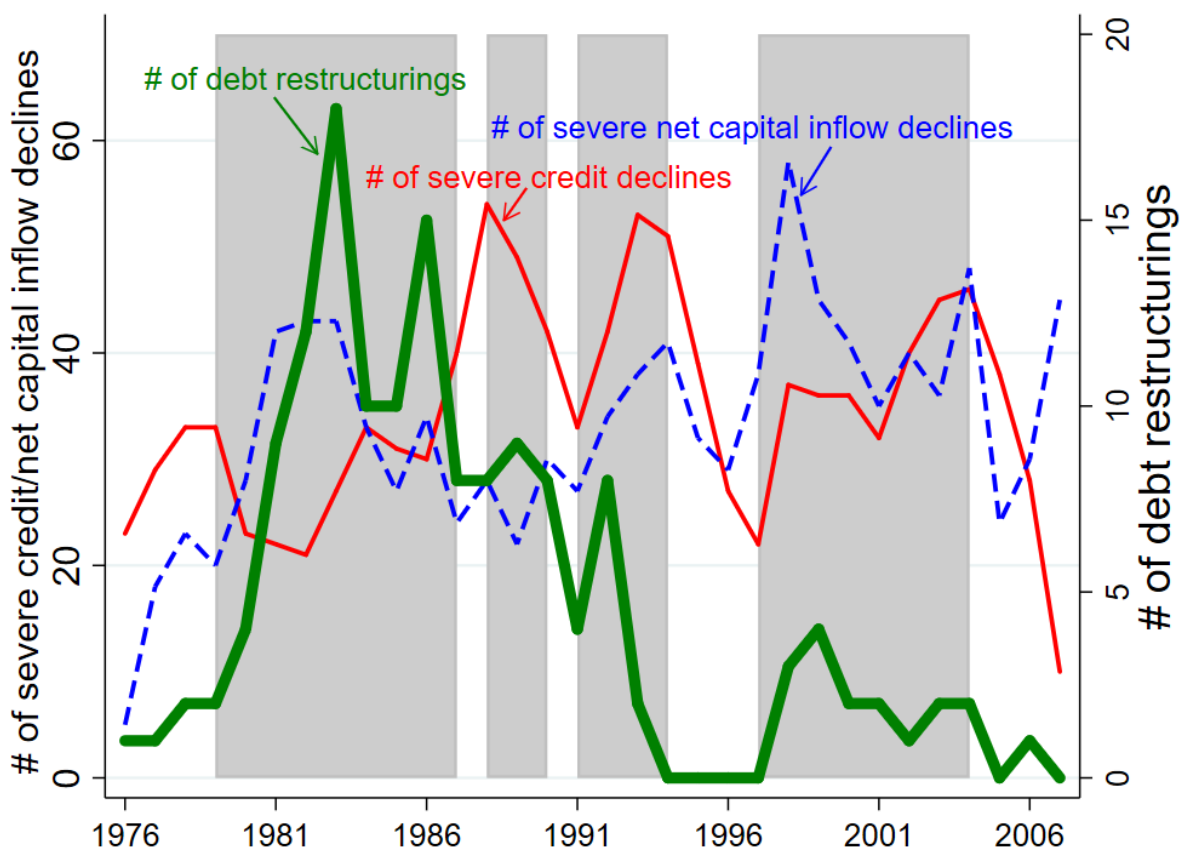

Notes: Debt restructuring episodes (start) come from Asonuma and Trebesch (2016). Severe credit declines are defined as observations where the cumulative percentage point difference in the credit-to-GDP ratio over three years, $d_{i, t+3}^{C}=100 \times\left(\mathrm{Credit}_{i, t+3} / \mathrm{GDP}_{i, t+3}-\right.$ Credit $_{i, t} / G D P_{i, t}$ ), is less than the 25th percentile of the of the distribution. Severe protracted net capital inflow declines (difference) are defined as observations where the cumulative percentage point difference in the net capital inflows-to-GDP ratio over three years, , $d_{t+3}^{N C I, D I F}=100 \times\left(N C I_{i, t+3} / G D P_{i, t+3}-N C I_{i, t} / G D P_{i, t}\right)$, is less than the 25 th percentile of the distribution. 
Figure 2: Debt Restructurings and Banking Crises

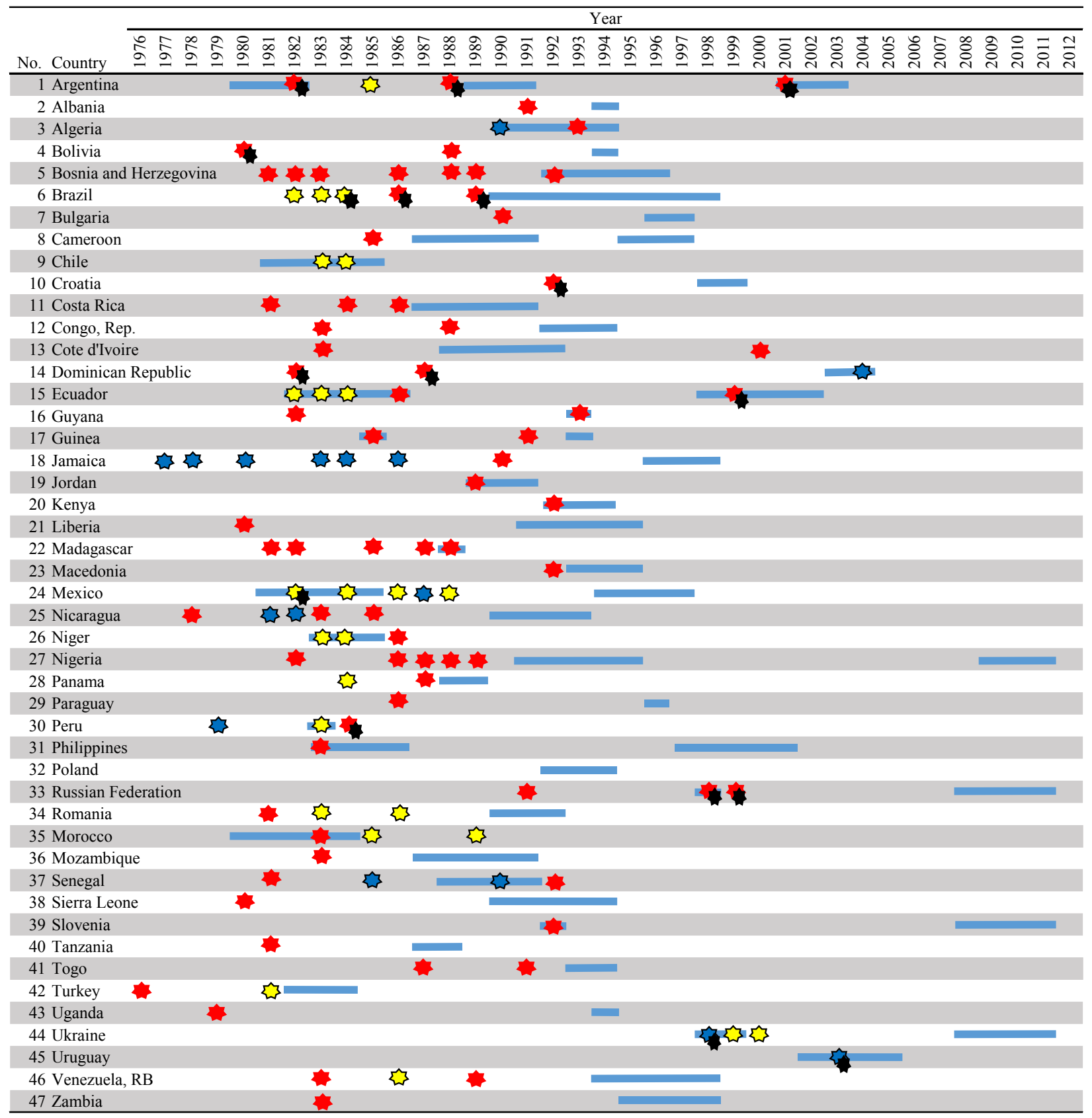

Notes: indicates the start year of post-default debt restructuring.

indicates the start year of weakly preemptive debt restructuring.

indicates the start year of strictly preemptive debt restructuring.

indicates the start year of domestic debt restructuring.

indicates banking crises.

The data on private external and domestic debt restructurings come from Asonuma and Trebesch (2016) and Asonuma and

Papaioannou (2016), respectively. The data on banking crises come from Laeven and Valencia (2013). Countries that experienced b oth debt resturucting and banking crisis are listed in the figure. 
Figure 2 reports both debt restructurings and banking crises for each country in our sample (summary statistics provided in Panel B of Table 1). One pattern of sequential events emerges from Figure 2: the start of debt restructurings precedes or coincides with that of banking crises. Prominent cases include: (i) Argentina 2001-05 debt restructuring and 2001-03 banking crisis, and (ii) Russia 1998-99 debt restructuring and 1998 banking crisis.

As shown in Panel B in Table 1, in 30 cases out of 91 post-default restructurings, banking crises occur in subsequent years (33 percent). The likelihood of banking crises after post-default restructurings is higher than the one for weakly preemptive ( 27 percent) or strictly preemptive restructurings (20 percent). In contrast, banking crises precede debt restructurings in 16 cases out of 39 weakly preemptive episodes ( 41 percent) and in 9 cases out of 21 strictly preemptive episodes (42 percent), respectively. The likelihood of weakly and strictly preemptive restructurings after banking crises is higher than the one for post-default restructurings (20 percent, 18 cases out of 91 episodes in total). The link between banking crises and restructurings is in line with Reinhart and Rogoff (2011b) and Balteanu and Erce (2018), though none of the previous studies distinguished the effects of different restructuring strategies.

Panel C in Table 1 reports that severe credit declines occur in around 49 percent of post-default restructurings i.e., 36 cases out of 73 cases in total-where credit data are available. In contrast, severe credit declines occur in 39 and 25 percent of weakly and strictly preemptive restructurings, respectively. Moreover, Panels D and E in Table 1 shows that severe protracted net capital inflow declines are more likely during post-default restructurings. On average, net capital inflow declines in 38 (33) percent of post-default restructurings, while only in 35 and 20 (31 and 10) percent of weakly preemptive and strictly preemptive restructurings, respectively.

Figure 3 contrasts the likelihood of these three events. One common trend emerges from Figure 3-also confirmed with the events under 5-year criterion as reported in Figure A1 in Appendix A.4-: all banking crises, severe credit and net capital inflow declines occur more likely following post-default restructurings than weakly or strictly preemptive restructurings. 
Figure 3: Debt Restructurings, Severe Credit and Net Capital Inflow Declines, 3-year Horizon
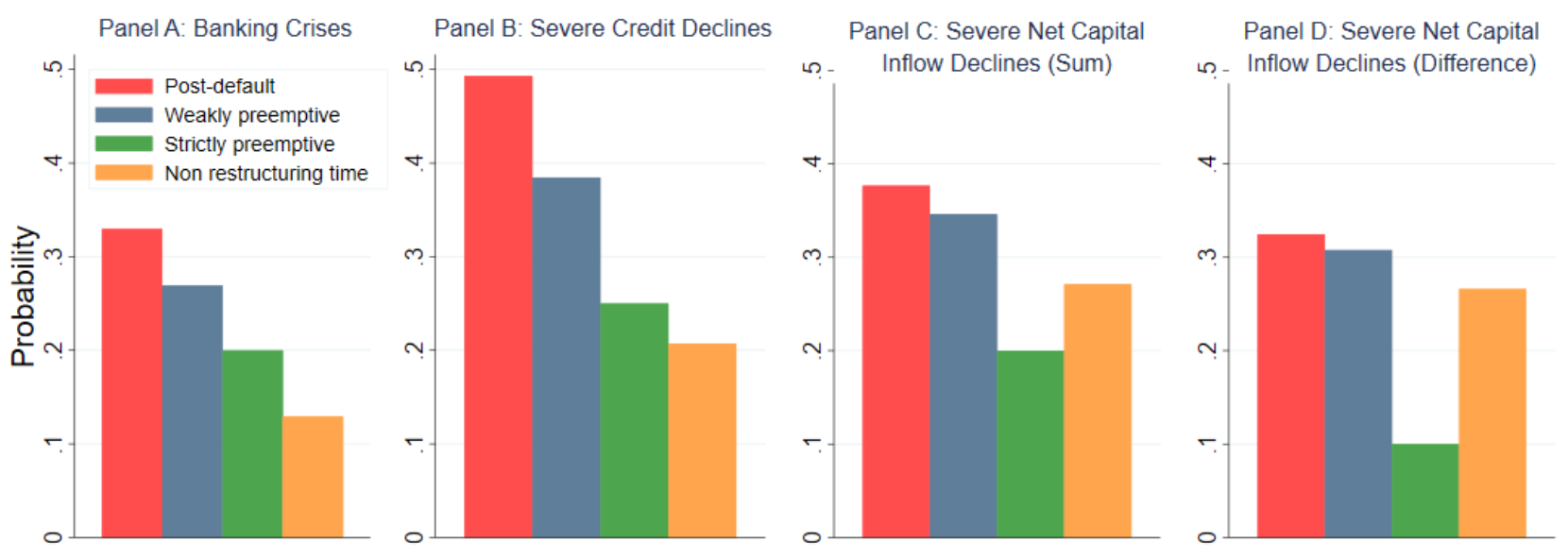

\begin{abstract}
Notes: Panel charts show the probability of banking crises (Panel A), severe credit declines (Panel B), and severe protracted net capital inflow declines (Panels $C$ and $D$ ), respectively.

Panel B: Severe credit declines are defined as observations where the cumulative percentage point difference in the credit-to-GDP ratio over three years, $d_{i, t+3}^{C}=100 \times\left(\right.$ Credit $_{i, t+3} / G D P_{i, t+3}-$ Credit $\left._{i, t} / G D P_{i, t}\right)$, is less than the 25th percentile of the distribution. Panel C: Severe protracted net capital inflow declines (sum) are defined as observations where the sum of cumulative percentage point differences in the net capital inflows-to-GDP ratio over three years, $d_{i, t+3}^{N C I, S U M}=100 \times \sum_{s=1}^{3}\left(N C I_{i, t+s} / G D P_{i, t+s}-\right.$ $\left.N C I_{i, t} / G D P_{i, t}\right)$, is less than the 25th percentile of the distribution.

Panel D: Severe protracted net capital inflow declines (difference) are defined as observations where the cumulative percentage point difference in the net capital inflows-to-GDP ratio over three years, $d_{t+3}^{N C I, D I F}=100 \times\left(N C I_{i, t+3} / G D P_{i, t+3}-N C I_{i, t} / G D P_{i, t}\right)$, is less than the 25th percentile of the distribution.

The sample after 2008 is dropped because macroeconomic variables in the period are largely influenced by the Global Financial Crisis. Debt restructuring episodes with more than one strategy within a window of $[-2,+3]$ years around the start year of a debt restructuring $t=0$ are coded with the worst strategy only.
\end{abstract}

\title{
B. Stylized Facts on GDP, Investment, Private Credit, and Capital Flows in Sovereign Debt Restructurings
}

\section{- $\quad$ Stylized fact 3: GDP and investment decline substantially in post-default restructurings, less severely in weakly preemptive restructurings, and are not affected in strictly preemptive cases.}

Figure 4 reports the dynamics of GDP and investment for our three restructuring strategies: ${ }^{18}$ GDP (real) is measured as a log-deviation from a Hodrick-Prescott $(\mathrm{H}-\mathrm{P})$ filtered trend and investment (real) is normalized at the pre-crisis $(t=0)$ level. The time horizon of each panel corresponds to the number of years since the pre-restructuring year, i.e., one year before the announcement or the default event. Both GDP and investment experience a severe decline following a post-default restructuring and they remain below the pre-crisis levels for several years (red lines in Panels A and B). A much smaller and short-lived drop in both GDP and investment occurs in the run-up to a weakly preemptive restructuring, and GDP and investment recover to their pre-crisis levels after only short periods (blue lines in Panels A and B). In

\footnotetext{
${ }^{18}$ See Benjamin and Wright (2009), Sturzenegger and Zettelmeyer (2006, 2008), Reinhart and Rogoff (2011a), Cruces and Trebesch (2013), Bai and Zhang (2012), Das et al. (2011, 2012), and Asonuma and Joo (2017) for stylized facts around sovereign debt restructurings.
} 
contrast, neither GDP nor investment contracts following a strictly preemptive restructuring (green lines in Panels A and B). ${ }^{19}$

Figure 4: GDP and Investment around Debt Restructurings, Average
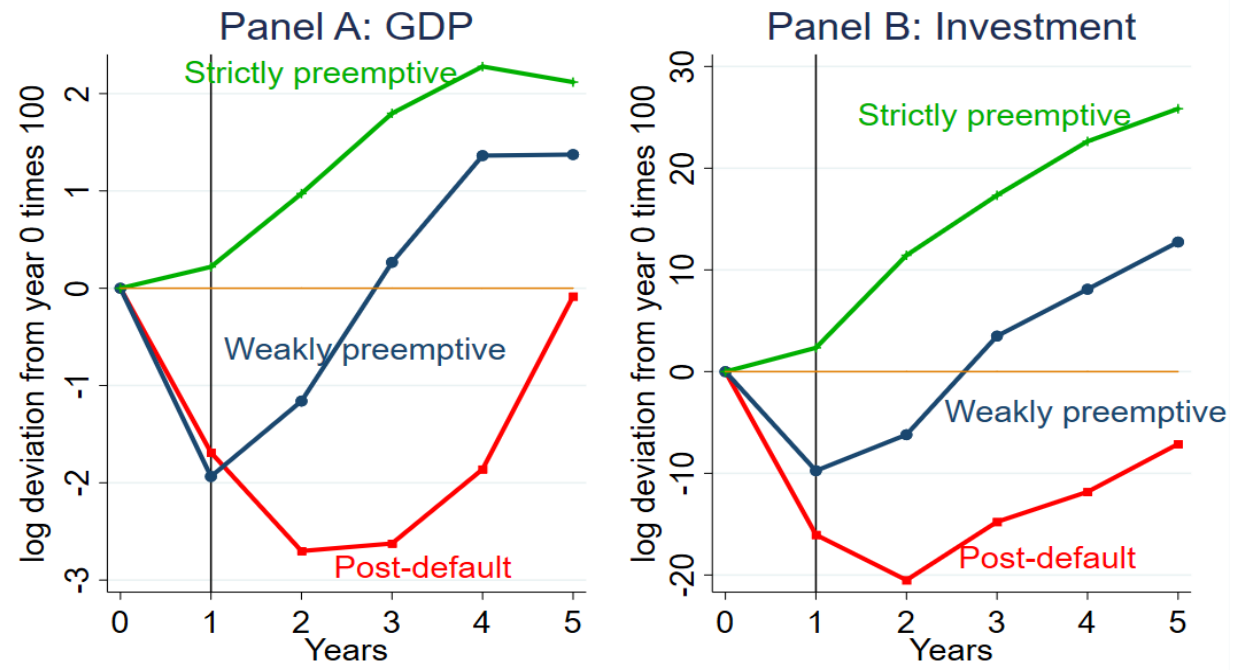

Data sources: Asonuma and Trebesch (2016) for restructurings, Penn World Table 8.0 (Feenstra et al., 2015) for GDP and investment. GDP (real) is measured as a deviation from a Hodrick-Prescott filtered trend and investment (real, flow) is normalized at the pre-crisis $(t=0)$ level. Black vertical lines correspond to the start of restructurings $(a t=1)$.

Figure 5: Private Credit, Lending Interest Rates, and Capital Flows around Debt Restructurings, Average
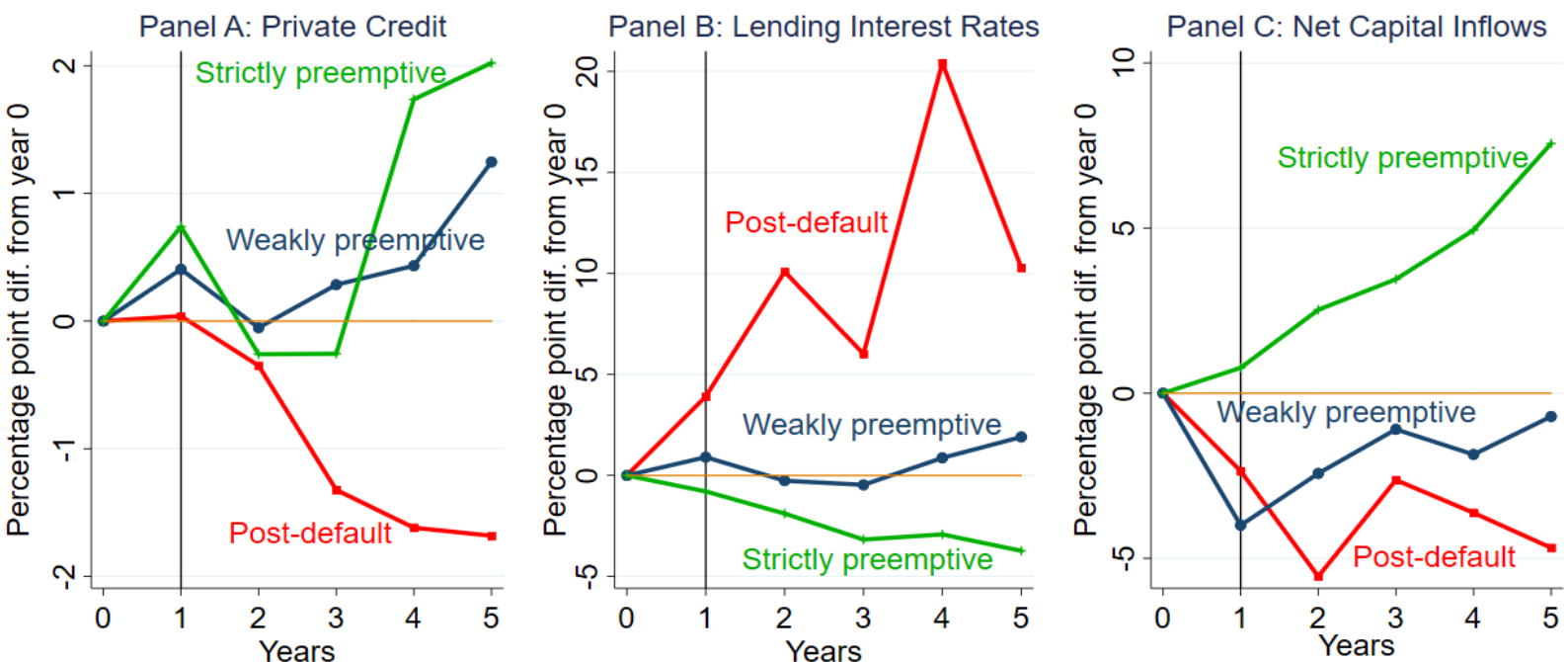

Data sources: Asonuma and Trebesch (2016) for restructurings, WB WDI for private credit and lending interest rates, and IMF WEO for net capital inflows. Private credits-to-GDP ratio, lending interest rates (nominal), and net capital inflows-to-GDP ratio are measured as a percentage point difference from the pre-crisis level $(t=0)$ respectively. Black vertical lines correspond to the start of restructurings $(t=$ 1).

${ }^{19}$ Figure E10 in Appendix E7 reports the dynamics of CPI inflation rate for the three restructuring strategies. 
While we observe qualitatively similar dynamics for GDP and investment, the magnitude of the decline in investment is larger than that of GDP in both post-default and weakly preemptive events. This is consistent with consumption smoothing during a crisis period where investment bears a disproportionate share of the adjustment relative to consumption. The decline in investment has an immediate impact on GDP - because investment is one of the components of GDP from the demand side - and also contributes to lower GDP growth in the following years. Table B1 in Appendix B shows the tight relationship between GDP growth and investment growth.

\section{- $\quad$ Stylized fact 4: Both private credit and capital inflows remain below the pre-crisis level and lending interest rates experience a sharp increase in post-default restructurings.}

Figure 5 reports the trend of private credit, lending interest rates, and net capital inflows. We follow the same presentation approach as in Figure 4 in terms of both the classification by restructuring strategies and normalization at the pre-crisis level. Private credit suffers a severe and prolonged decline following post-default restructurings and recovers at the pre-crisis level at the third year since the start of restructurings (red line in Panel A). In contrast, private credit remains more resilient before and after both weakly and strictly preemptive (blue and green lines in Panel A). The lending interest rates experience a sharp and temporary increase in post-default restructurings (red line in Panel B) accompanied by a sharp drop in private credit, followed by a return to the pre-crisis level (possibly as demand-side effects of credit dominate supply-side ones). In contrast, the lending interest rates remain stable in both weakly and strictly preemptive restructurings (blue and green lines in Panel B).

Lastly, net capital inflows experience a severe and protracted decline in post-default restructurings (red line in Panel $\mathrm{C}$ ). While net capital flows are volatile, they remain subdued and below the pre-crisis level over the following five years. Weakly preemptive restructurings are associated with a milder decline in net capital flows (blue line in Panel C). In contrast, net capital inflows are not affected following a strictly preemptive restructuring (green line in Panel C).

\section{Data on Macroeconomic Variables}

Following conventions in the literature, we use data at an annual frequency to secure the widest possible country coverage. Both real US-dollar GDP, real US-dollar GDP per capita and investment (denominated in US dollar) data are from the Penn World Table 8.0 (Feenstra et al., 2015). ${ }^{20}$ For banking sector indicators, both private credit and lending interest rates are from the World Bank World Development Indicators (WDI) database. Net capital inflows are from IMF World Economic Outlook (WEO).

Our set of control variables follows closely Jordà et al., (2016). This includes a lagged dependent variable for each regression, respectively (for instance, lagged GDP growth rate for the GDP

\footnotetext{
${ }^{20}$ Debtors' GDP, GDP per capita, and investment are measured in constant US dollar price.
} 
growth regression) and the cyclical component of log of real GDP per capita. Appendix A.2 summarizes data sources of these explanatory variables.

\section{Time Sample}

Our sample covers the period 1970-2013. We do not consider the period prior to 1970 because there were few debt restructurings between 1945 and 1970 (Reinhart and Rogoff 2011a; Sturzenegger and Zettelmeyer 2006). The most recent restructuring episodes in Asonuma and Trebesch (2016) are Ecuador 2008-09 and Seychelles 2008-10. Post-restructuring years for these two restructurings are fully covered in our sample.

We follow Jordà and Taylor (2016) and focus on the sample of countries experiencing a specific event. In our benchmark, the sample of 68 countries is set as those which have experienced at least one debt restructuring over the specified horizon. We also apply a full country coverage including non-restructuring countries for a robustness check (Appendix E.1) to contrast our estimates with those in previous studies (Borensztein and Panizza 2009; Kuvshinov and Zimmermann 2016). Following previous studies (Cruces and Trebesch 2013; Asonuma and Trebesch 2016), we consider each restructuring as an independent event - there are overlapping observations included in our sample. This classification is based on the criteria such that both debt instruments subject to exchange and dates of announcement and of settlements in one restructuring differ from those in other restructurings. Appendix E.4 shows the robustness of our results under different approaches for handling overlapping restructurings.

\section{Local Projection Approach}

\section{A. Endogeneity of Debt Restructuring Decisions}

Countries experiencing restructurings are likely to differ from others in many aspects. Moreover, the restructuring strategy (e.g., preemptive vs post-default) is an endogenous choice by the sovereign debtor (Asonuma and Trebesch, 2016). As a result, conventional ordinary least square (OLS) estimation results - reported in Appendix C.1 - could be driven by the characteristics of countries experiencing restructurings rather than the effect of debt restructuring itself.

Table 2 shows the difference in key macroeconomic and structural variables, among the different treatment groups - the start year and one year before the start year of debt restructurings — and the control group. The variables considered, drawing on Asonuma et al. (2016) and Kuvshinov and Zimmermann (2016), include: (1) credit ratings from the Institutional Investor magazine; (2) changes in credit ratings; (3) short-term interest payments-to-GDP ratio; (4) total interest payments-to-GDP ratio; (5) GDP growth rate; (6) cyclical component of log of GDP; and (7) an index of political stability. 
Table 2: Characteristics of the Treatment and Control Groups

\begin{tabular}{|c|c|c|c|c|c|c|c|}
\hline & $\begin{array}{l}\text { Credit } \\
\text { ratings }\end{array}$ & $\begin{array}{l}\text { Change in } \\
\text { credit } \\
\text { ratings }\end{array}$ & $\begin{array}{c}(3) \\
\text { Interest } \\
\text { payments } \\
\text { (short- } \\
\text { term)/GDP× } \\
100\end{array}$ & $\begin{array}{c}\text { Interest } \\
\text { payments } \\
(\text { total }) / G D P \\
\times 100\end{array}$ & $\begin{array}{l}\text { GDP growth } \\
\text { rate } \times 100\end{array}$ & $\begin{array}{c}\text { Cyclical } \\
\text { comp. of log } \\
\text { of GDP } \times 100\end{array}$ & $\begin{array}{l}\text { Political } \\
\text { stability } \\
\text { (civil } \\
\text { liberties) }\end{array}$ \\
\hline Post-default & $\begin{array}{l}-2.142 * \\
(1.246)\end{array}$ & $\begin{array}{c}-2.297 * * * \\
(0.415)\end{array}$ & $\begin{array}{c}0.224 * * * \\
(0.076)\end{array}$ & $\begin{array}{c}1.352 * * * \\
(0.301)\end{array}$ & $\begin{array}{c}-3.423 * * * \\
(0.823)\end{array}$ & $\begin{array}{c}-1.435^{*} \\
(0.849)\end{array}$ & $\begin{array}{c}0.318 * * * \\
(0.118)\end{array}$ \\
\hline $\begin{array}{l}\text { Post-default } \\
\qquad \text { (a year before start) }\end{array}$ & $\begin{array}{c}0.473 \\
(1.310)\end{array}$ & $\begin{array}{c}-1.368 * * * \\
(0.430)\end{array}$ & $\begin{array}{c}0.300 * * * \\
(0.076)\end{array}$ & $\begin{array}{c}1.715 * * * \\
(0.303)\end{array}$ & $\begin{array}{c}-1.650 * * \\
(0.822)\end{array}$ & $\begin{array}{c}0.473 \\
(0.848)\end{array}$ & $\begin{array}{c}0.344 * * * \\
(0.118)\end{array}$ \\
\hline $\begin{array}{l}\text { Weakly preemptive } \\
\text { (start year) }\end{array}$ & $\begin{array}{c}-6.028 * * * \\
(1.642)\end{array}$ & $\begin{array}{c}-3.312 * * * \\
(0.520)\end{array}$ & $\begin{array}{l}0.254 * * \\
(0.115)\end{array}$ & $\begin{array}{c}2.030 * * * \\
(0.458)\end{array}$ & $\begin{array}{l}-2.742 * * \\
(1.197)\end{array}$ & $\begin{array}{c}-3.558 * * * \\
(1.152)\end{array}$ & $\begin{array}{c}0.236 \\
(0.182)\end{array}$ \\
\hline $\begin{array}{l}\text { Weakly preemptive } \\
\qquad \text { (a year before start) }\end{array}$ & $\begin{array}{l}-1.818 \\
(1.645)\end{array}$ & $\begin{array}{c}-3.551 * * * \\
(0.537)\end{array}$ & $\begin{array}{c}0.475 * * * \\
(0.116)\end{array}$ & $\begin{array}{c}2.150 * * * \\
(0.459)\end{array}$ & $\begin{array}{c}-3.290 * * * \\
(1.198)\end{array}$ & $\begin{array}{l}-1.071 \\
(1.154)\end{array}$ & $\begin{array}{l}0.310^{*} \\
(0.182)\end{array}$ \\
\hline $\begin{array}{l}\text { Strictly preemptive } \\
\text { (start year) }\end{array}$ & $\begin{array}{c}-9.298 * * * \\
(2.311)\end{array}$ & $\begin{array}{c}-2.052 * * * \\
(0.751)\end{array}$ & $\begin{array}{c}0.124 \\
(0.173)\end{array}$ & $\begin{array}{l}1.142 * \\
(0.688)\end{array}$ & $\begin{array}{l}-0.676 \\
(1.588)\end{array}$ & $\begin{array}{l}-3.533 * * \\
(1.651)\end{array}$ & $\begin{array}{c}0.117 \\
(0.245)\end{array}$ \\
\hline $\begin{array}{l}\text { Strictly preemptive } \\
\qquad \text { (a year before start) }\end{array}$ & $\begin{array}{c}-7.078 * * * \\
(2.370)\end{array}$ & $\begin{array}{l}-0.593 \\
(0.772)\end{array}$ & $\begin{array}{l}0.0536 \\
(0.173)\end{array}$ & $\begin{array}{c}0.438 \\
(0.687)\end{array}$ & $\begin{array}{l}-1.444 \\
(1.587)\end{array}$ & $\begin{array}{l}-2.965^{*} \\
(1.650)\end{array}$ & $\begin{array}{c}0.177 \\
(0.245)\end{array}$ \\
\hline Constant & $\begin{array}{c}28.64 * * * \\
(0.255)\end{array}$ & $\begin{array}{c}0.563 * * * \\
(0.082)\end{array}$ & $\begin{array}{c}0.269 * * * \\
(0.014)\end{array}$ & $\begin{array}{c}2.024 * * * \\
(0.057)\end{array}$ & $\begin{array}{c}3.904 * * * \\
(0.152)\end{array}$ & $\begin{array}{c}0.163 \\
(0.153)\end{array}$ & $\begin{array}{c}4.091 * * * \\
(0.023)\end{array}$ \\
\hline$R$-squared & 0.029 & 0.089 & 0.024 & 0.050 & 0.016 & 0.011 & 0.010 \\
\hline Number of countries & 63 & 63 & 54 & 54 & 64 & 59 & 62 \\
\hline Number of observations & 1,566 & 1,503 & 2,053 & 2,053 & 2,373 & 2,159 & 2,405 \\
\hline
\end{tabular}

Notes: The table shows the difference between the treatment groups (the start year and a year before the start of debt restructurings) and the control group (other observations) in terms of seven variables. The difference between treatment and control groups is estimated by regressing each of the variables on two sets of dummies for the three restructuring strategies, one set which takes unity at the start and the other which takes unity on the year before the start. The average value for normal times is taken from the estimated constant term. The average values for treatment groups are calculated as the sum of the estimated constant term and each estimated coefficient on debt restructuring dummy. All regressions include country fixed effects. The sample period is $1970-2013 .{ }^{* * *},{ }^{* *}$, and ${ }^{*}$ indicate statistical significance at 1 percent, 5 percent, and 10 percent level, respectively. Robust standard errors, clustered at the country level, are in parentheses. Credit ratings take a value between 0 and 100 , and a greater value implies a smaller default risk. The political stability index takes a value between 0 and 7 , and the greater the value the greater the political instability.

Columns (1), (2), and (4) suggest that there are significant differences in credit ratings, changes in credit ratings, and total interest payments-to-GDP ratio between observations in the start of three types of restructurings and normal times. In contrast, a significant difference arises in short term interest payments-to-GDP ratio, GDP growth rate, and the index of political stability only between observations in the year before both post-default and weakly preemptive episodes and normal times. It is worth noting that for some variables, preemptive restructurings are not associated with more favorable ex ante outcomes (e.g., preemptive restructurings on average had a worse credit rating than post-default restructurings). 
Table 3: Predicting the Start of Debt Restructurings, Probit

Dep. Var. = Dummy Taking 1 at the Start of Debt Restructuring

\begin{tabular}{|c|c|c|c|c|c|c|}
\hline & \multicolumn{2}{|c|}{ Post-default } & \multicolumn{2}{|c|}{ Weakly preemptive } & \multicolumn{2}{|c|}{ Strictly preemptive } \\
\hline & $(1)$ & $(2)$ & $(3)$ & $(4)$ & $(5)$ & $(6)$ \\
\hline \multirow[t]{2}{*}{ \# of past post-default } & $0.232 * * *$ & $0.479 * * *$ & $-0.560 * * *$ & $-0.674 * * *$ & 0.020 & 0.078 \\
\hline & $(0.035)$ & $(0.079)$ & $(0.137)$ & $(0.206)$ & $(0.174)$ & $(0.268)$ \\
\hline \multirow[t]{2}{*}{ \# of past weakly preemptive } & -0.047 & $0.310^{* * *}$ & $0.508 * * *$ & $0.499 * * *$ & $0.407 * * *$ & 0.173 \\
\hline & $(0.064)$ & $(0.105)$ & $(0.063)$ & $(0.135)$ & $(0.115)$ & $(0.208)$ \\
\hline \multirow[t]{2}{*}{ \# of past strictly preemptive } & -0.056 & 0.0419 & $-0.276 * *$ & -0.197 & $0.693 * * *$ & $0.605 * * *$ \\
\hline & $(0.084)$ & $(0.088)$ & $(0.129)$ & $(0.140)$ & $(0.127)$ & $(0.194)$ \\
\hline \multirow[t]{2}{*}{ \# of past banking crises } & & $-0.199 * * *$ & & $-0.140 * *$ & & -0.110 \\
\hline & & $(0.044)$ & & $(0.066)$ & & $(0.089)$ \\
\hline \multirow[t]{2}{*}{ External debt-to-GDP ratio, lag } & & $-0.626 * * *$ & & -0.149 & & -0.636 \\
\hline & & $(0.220)$ & & $(0.369)$ & & $(0.522)$ \\
\hline \multirow[t]{2}{*}{ Total interest payments-to-GDP ratio, lag } & & $9.814 * * *$ & & $6.417 * *$ & & 5.956 \\
\hline & & $(2.067)$ & & $(2.888)$ & & $(4.454)$ \\
\hline \multirow[t]{2}{*}{ Change in credit ratings, lag } & & $-0.054 * *$ & & $-0.068 * * *$ & & 0.004 \\
\hline & & $(0.023)$ & & $(0.026)$ & & $(0.047)$ \\
\hline \multirow[t]{2}{*}{ Cyclical comp. of log of GDP per capita, lag } & & 1.773 & & -2.284 & & $-6.675^{*} *$ \\
\hline & & $(1.327)$ & & $(2.295)$ & & $(3.183)$ \\
\hline \multirow[t]{2}{*}{ GDP growth rate, lag } & & $-3.311 * *$ & & -0.026 & & -0.342 \\
\hline & & $(1.389)$ & & $(2.265)$ & & $(2.940)$ \\
\hline \multirow[t]{2}{*}{ Freedom index, civil liberty, lag } & & $0.147 * *$ & & $-0.155^{*}$ & & 0.036 \\
\hline & & $(0.060)$ & & $(0.088)$ & & $(0.110)$ \\
\hline Likelihood ratio & 43.18 & 74.59 & 79.82 & 89.08 & 37.70 & 24.11 \\
\hline Likelihood ratio ( $p$-value) & 0.000 & 0.000 & 0.000 & 0.000 & 0.000 & 0.000 \\
\hline Pseudo $R$-squared & 0.054 & 0.186 & 0.194 & 0.353 & 0.152 & 0.007 \\
\hline Number of observations & 2,816 & 1,244 & 2,816 & 1,244 & 2,816 & 1,244 \\
\hline
\end{tabular}

Notes: The sample period is $1970-2013 .{ }^{* * *},{ }^{* *}$, and ${ }^{*}$ indicate statistical significance at 1 percent, 5 percent, and 10 percent level, respectively. Standard errors are in parentheses. Total number of past debt restructurings is used to predict post-default and weakly preemptive debt restructurings. Number of past debt restructurings for the last six years is used to predict strictly preemptive cases.

As expected, these results show that countries indeed have different characteristics prior to any type of restructurings, raising concerns over the endogeneity on the restructuring decision (and to some extent on the choice of restructuring strategies). To address this issue, we use external debt-to-GDP ratio, total interest payments-to-GDP ratio, change in credit ratings, the cyclical component of log of GDP per capita, GDP growth rate, and freedom index of civil liberties as explanatory variables to predict the start of each type of restructuring. ${ }^{21}$ Countries that experienced default or debt restructuring in the past are more likely to experience another default or restructuring (Reinhart et al. 2003; Asonuma 2016). We control for this feature by including as explanatory variables the number of post-default, weakly, and strictly preemptive restructurings and banking crises that took place in the last six years. We apply a probit model to estimate separate equations for the start of each type of restructurings.

\footnotetext{
${ }^{21}$ The GDP growth rate is not included in the set of explanatory variables because cyclical component of GDP growth is included as a control variable in the second stage, estimating the effects of restructurings on macroeconomic and banking sector variables.
} 
Results of the probit model are reported in Table 3. Based on the results reported in columns (2), (4), and (6), Panel A of Figure 6 plots the area under the Receiver Operating Characteristic (ROC) curve for the three types of debt restructurings, respectively. The ROC area takes a value between 0.5 and 1 . A value of 0.5 indicates that regressors have no explanatory power to classify observations (the start of debt restructuring vs normal times) - so that the model predictions are random. On the opposite extreme, a value of 1 indicates perfect classification power. For each type of debt restructurings, three ROC areas are reported based on the three different sets of regressors; $x 1$ denotes the set of regressors: the numbers of past post-default, weakly preemptive, strictly preemptive debt restructurings, and banking crises, external debt-to-GDP ratio, total interest payments-to-GDP ratio, changes in credit ratings, the cyclical component of log of GDP per capita, the GDP growth rate, the freedom index of civil liberty, and country fixed effects; $x 2$ denotes the set of regressors: the numbers of past post-default, weakly preemptive, strictly preemptive debt restructurings, banking crises, and country fixed effects. While there is no established threshold for this statistic, a ROC curve above 0.7 is generally considered to be adequate (Schularick and Taylor 2012). We choose $\mathrm{x} 1$ as the set of instruments in the first-stage regression. Appendix E.6 shows the robustness of our baseline set of instruments under a different approach of setting instruments.

Using these explanatory variables, we predict probabilities of three types of restructurings. Panel B of Figure 6 shows kernel density estimates for the predicted likelihood of debt restructuring for each type of strategies. In each panel, we report two kernel density estimates. One is for observations where debt restructurings actually occur (treatment group), and the other is for those that debt restructurings do not occur (control group). A substantial difference in the distribution of predicted likelihoods between the treatment and control groups for all types of debt restructurings clearly indicates that instruments have a high explanatory power to differentiate between these two groups.

Figure 6: Classification Power of the First Stage Regressors
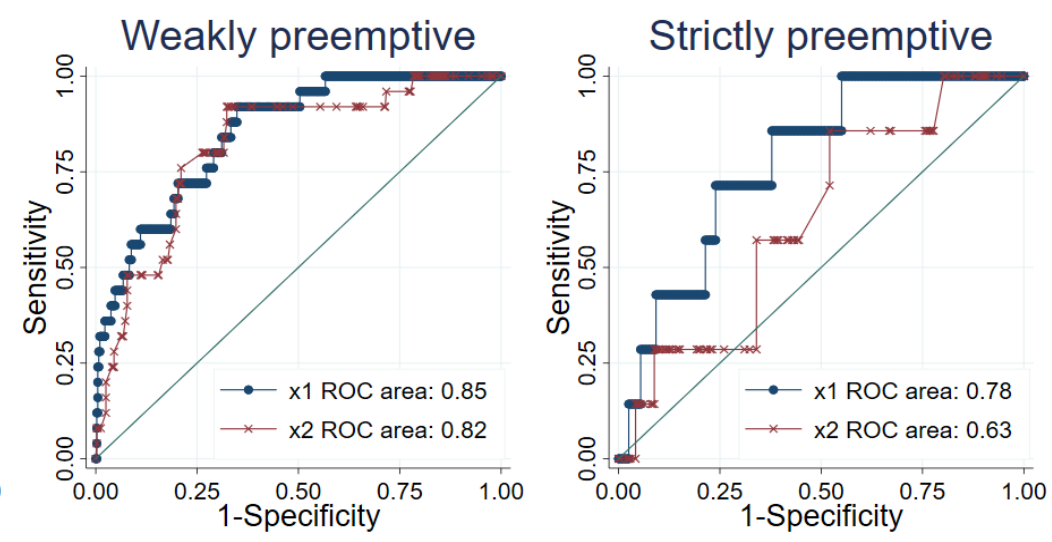
Panel B: Kernel Density Estimates for Treatment and Control Groups
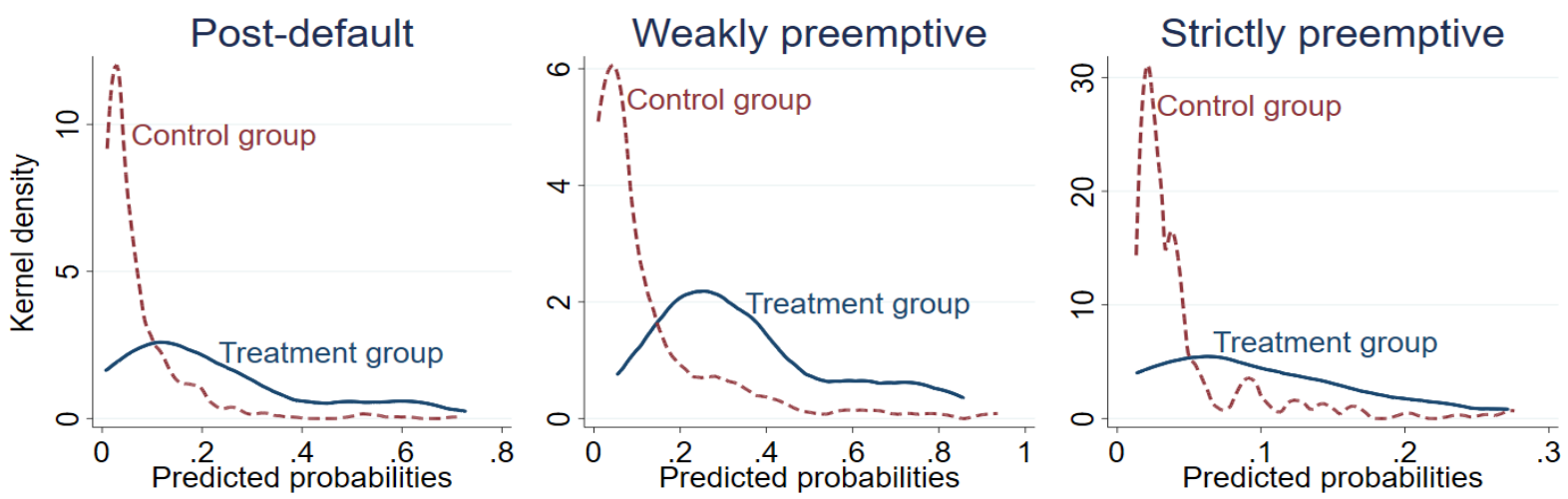

Notes: Panel A shows the area under the ROC curve. The ROC area takes a value between 0.50 and 1. Taking a value of 0.50 indicates that regressors have no classification power when differentiating observations at the start of debt restructurings from other observations. Taking a value of 1 indicates that regressors have a perfect classification power. See the main text for the definition of $x 1$ and $x 2$. Panel $\mathrm{B}$ shows kernel density estimates for observations of the start of debt restructurings - we call the treatment group - , and other observations-we call the control group.

\section{B. Augmented Inverse Probability Weighted (AIPW) Estimation}

Since the dominant determinants of the restructuring choice differ among the three strategies, we implement the Augmented Inverse Probability Weighted (AIPW) estimator by running separate regressions for each type of restructurings, rather than including these three dummy variables jointly in one regression.

In the first stage, we estimate propensity scores in the sample, which corresponds to the probability that a restructuring event occurs. We use probit models, treating each restructuring strategy separately, as follows:

$$
\operatorname{Pr}(R)_{i, t+1}=\boldsymbol{\Phi}\left(\boldsymbol{Z}_{i, t}, \boldsymbol{X}_{i, t}, \boldsymbol{\gamma}^{R}\right) \text { for } R=\{P D, \text { Weakly, Strictly }\}
$$

where $\operatorname{Pr}(R)_{i, t+1}$ denotes the probability that a type $R$ debt restructuring event occurs in country $i$ in year $t+1 ; \boldsymbol{Z}_{\boldsymbol{i}, t}$ is a vector of lagged instruments (in year $t$ ) to predict the restructuring events with three strategies defined in Section III.A. Regressors from the second stage, $\boldsymbol{X}_{i, t}$, are also included in the first-stage estimation. $\gamma^{R}$ indicates vectors of coefficients to be estimated for each type of debt restructuring strategies $R=\{P D$, Weakly, Strictly $\}$. $\boldsymbol{\Phi}$ denotes the normal cumulative distribution function.

In the second stage, we correct for potential bias in our sample by using the inverse of the estimated propensity score obtained in the first stage: $1 / \widehat{\operatorname{Pr}(R})_{i, t+1}$. Under this weighting, the observations that are less likely associated with restructurings (for instance, those with low total interest payments-to-GDP ratio and no change in the credit ratings) account for a larger weight in the AIPW estimates. Intuitively, this adjustment generates a hypothetical situation where there is no bias between restructuring and non-restructuring events in contrast with the real world where restructurings are triggered by common features (for which we control by assigning asymmetric weights). 
With the AIPW estimates obtained through this bias correction process, we interpret the estimated coefficients as the average treatment effect (ATE). This corresponds to a difference in average debt restructuring effects between observations that actually experience debt restructurings and those that do not experience debt restructurings. To acquire the average effect for each of the treatment groups and the control groups, we estimate local projections as follows:

$$
\begin{aligned}
g_{i, t+h} & =\alpha_{i}^{R, h}+\Lambda^{R, h} D_{i, t+1}^{R}+\boldsymbol{X}_{i, t} \boldsymbol{\beta}^{R . h}+\epsilon_{i, t+h}^{R}, \\
\text { for } R & =\{P D, \text { Weakly, Strictly }\} \text { and } h=1,2, \ldots, 5
\end{aligned}
$$

where $g_{i, t+h}=100 \times\left(G D P_{i, t+h}-G D P_{i, t}\right) / G D P_{i, t}$ is the cumulative GDP growth from time $t$ to $t+h$ in country $i ; D_{i, t+1}^{R}$ denotes three dummy variables taking unity if there is a post-default, weakly preemptive, and strictly preemptive debt restructuring at year $t+1$ in country $i$, respectively; $\alpha_{i}^{R, h}$ denotes the country fixed effects for each regression; $\Lambda^{R, h}$ and $\boldsymbol{\beta}^{R . h}$ indicate coefficients to be estimated; and $\epsilon_{i, t+h}^{R}$ is an error term for each regression. Following Jordà (2005) and Jordà and Taylor (2016), we include fixed effects which account for variation in the degree of financial liberalization and other macroeconomic differences across countries.

We denote the predicted dependent variables as

$$
\begin{aligned}
\hat{g}_{i, t+h}^{R} & =\hat{\alpha}_{i}^{R, h}+\hat{\Lambda}^{R, h} D_{i, t+1}^{R}+\boldsymbol{X}_{i, t} \widehat{\boldsymbol{\beta}}^{R . h}, \\
\text { for } R & =\{P D, \text { Weakly, Strictly }\} \text { and } h=1,2, \ldots, 5
\end{aligned}
$$

where a hat indicates an estimated coefficient. The average treatment effect of each restructuring strategy on GDP growth for $h$-year horizon is computed as follows:

$$
\begin{aligned}
& \left.A T E\left(\Lambda^{R, h}\right)=\frac{1}{N_{R}} \sum_{i} \sum_{t} \frac{\hat{g}_{i, t+h}^{R} D_{i, t+1}^{R}}{P r(R)_{i, t+1}}-\frac{1}{N_{N o n-R}} \sum_{i} \sum_{t} \frac{\hat{g}_{i, t+h}^{R}\left(1-D_{i, t+1}^{R}\right)}{1-\operatorname{Pr}(R)}\right)_{i, t+1} \\
& \quad \text { for } R=\{P D, \text { Weakly, Strictly }\} \text { and } h=1,2, . ., 5
\end{aligned}
$$

where $N_{R}$ indicates the number of observations from the start of type $R$ debt restructurings; $N_{N o n-R}$ indicates the number of observations which are complement to the sample of restructurings; $\left.{ }^{22} \widehat{\operatorname{Pr}(R}\right)_{i, t+1}$ denotes the estimated probability of type $R$ debt restructurings; and $\hat{g}_{i, t+h}^{R}$ for $R=\{P D$, Weakly, Strictly $\}$ is the predicted dependent variable.

Based on the estimation results in Table C.2 in Appendix C.2, Figure 7 reports the cumulative responses for macroeconomic and banking sector variables. Investment, private credit, and net capital inflows are in percentage point difference in GDP from the pre-restructuring level (at $\mathrm{t}$ ) GDP and lending interest rates are in cumulative rate of change and cumulative percentage point

\footnotetext{
${ }^{22}$ Since sovereigns make restructuring strategy choice sequentially, i.e. at different points of time (Asonuma and Trebesch 2016), the complement to one type of restructurings includes other restructuring strategies. Excluding these sample from the complement does not change our AIPW estimation results given the large size of non-restructuring observations (repayment choice).
} 
difference in level, respectively from the pre-restructuring year. Due to limited data availability, we obtain AIPW estimates for the lending interest rates under both weakly and strictly preemptive restructurings. ${ }^{23}$ The solid lines in red and the gray bands indicate the point estimates and 95 percent confidence intervals for post-default restructurings, respectively. The solid and dotted lines in blue and green indicate the point estimates and 95 percent confidence intervals for weakly and strictly preemptive restructurings, respectively. Post-default restructurings experience more severe and prolonged declines in GDP and investment than weakly preemptive restructurings, with strictly preemptive restructurings experiencing the mildest impacts (Panels A and B). Declines in GDP and investment for weakly preemptive restructurings past the third year are likely driven by continued weakness after the completion of the restructuring - the duration of weakly preemptive restructurings is 1.2 years on average.

Post-default restructurings experience a severe and prolonged decline in private credit (Panel C). In parallel, we observe a large and protracted rise in lending interest rates (Panel D). In contrast, the negative effect on private credit from weakly preemptive restructurings is milder (Panel C). Capital inflows decline severely after post-default episodes and mildly after weakly preemptive episodes (Panel E). Loss of market access by sovereigns is typically accompanied by the loss of market access by both domestic banks and corporates. Moreover, Panels A, B, C, and E in Figure C1 in Appendix C.1 show the OLS local projection estimates for GDP, investment, private credit, and net capital inflows for the three restructuring strategies which confirm the robustness of our baseline AIPW results. The difference between AIPW and OLS estimates is driven by forecast errors of both restructuring and non-restructuring observations: Larger AIPW estimates (than OLS estimates) stem from occurrence of restructuring events which were predicted with low probability at year t. Appendix E.6 also shows the robustness of our baseline AIPW estimation results under a different approach of setting instruments.

\footnotetext{
${ }^{23}$ We merge lending interest rate observations for weakly and strictly preemptive restructurings together due to limited observations of both lending interest rates and a set of controls (changes in credit ratings and the total interest payments-to-GDP ratio) for each restructuring strategy.
} 
Figure 7: Local Projections, AIPW
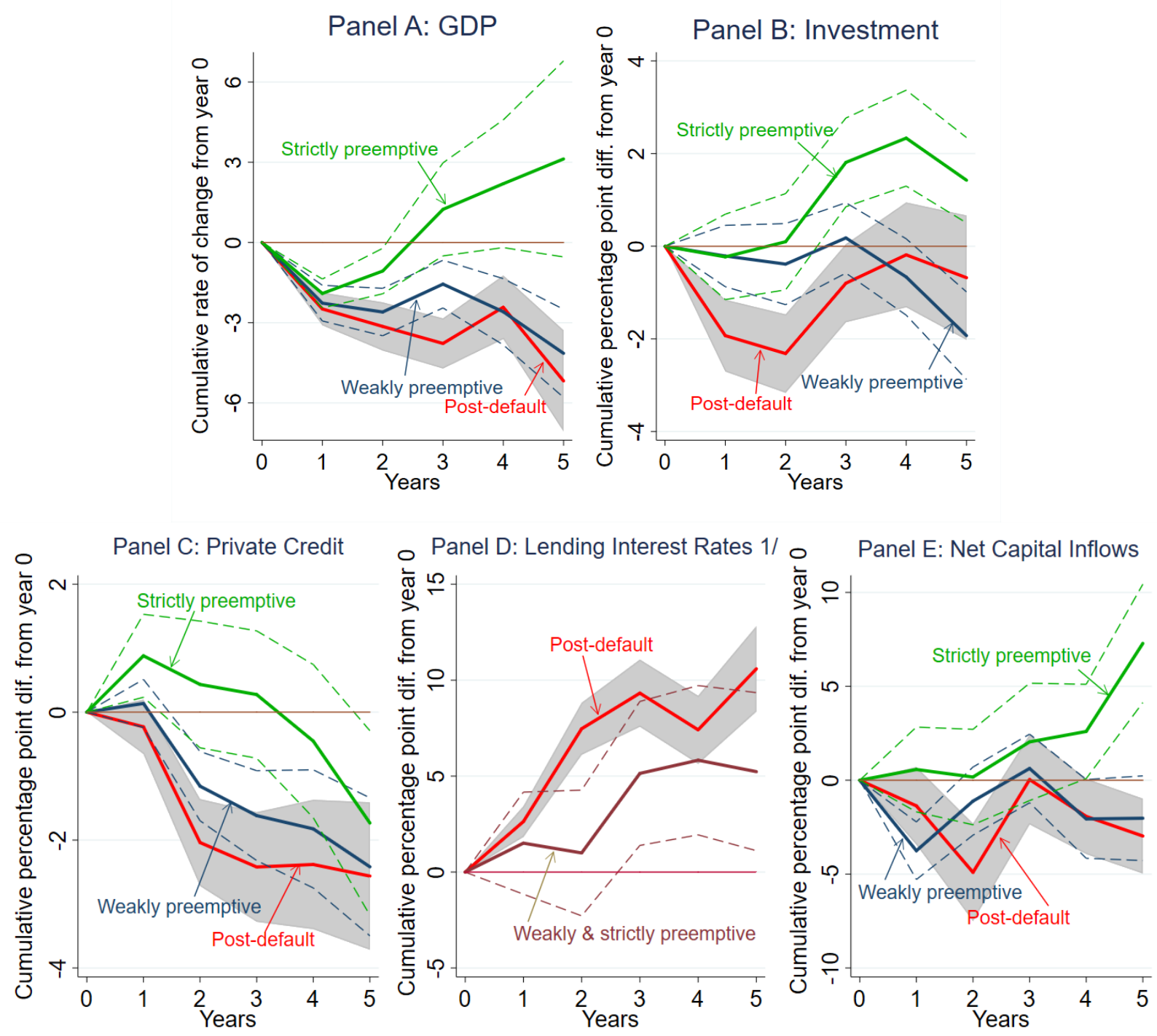

Notes: The figure shows local projections of the variables shown in each panel for $h=1,2, \ldots, 5$, where $h$ indicates horizon. Solid lines in red, blue, green, and brown are point estimates. Gray bands and dotted lines in blue, green, and brown are 95 percent confidence intervals. The sample period is 1970-2013.

1 / Estimates for the lending interest rates merge observations for weakly and strictly preemptive restructurings together due to limited observations of both lending interest rates and a set of controls (changes in credit ratings and the total interest payments-to-GDP ratio) for each restructuring strategy.

Moreover, Panels A, B, C, and E in Figure C1 in Appendix C.1 show the OLS local projection estimates for GDP, investment, private credit, and net capital inflows for the three restructuring strategies which confirm the robustness of our baseline AIPW results. The difference between AIPW and OLS estimates is driven by forecast errors of both restructuring and non-restructuring observations: Larger AIPW estimates (than OLS estimates) stem from occurrence of restructuring events which were predicted with low probability at year t. Appendix E.6 also shows the robustness of our baseline AIPW estimation results under a different approach of setting instruments. 


\section{Role of Capital Inflow-Credit Channel}

Next, we dig further into the link among capital inflows, private credit, investment, and GDP growth, and study the extent to which the linkage among these variables helps understand the different performance after different debt restructuring approaches. Following conventions in the literature (Calvo et al. 1998), we define severe sudden stops for each restructuring strategy as described below.

- Definition vi. A 'severe sudden stop' is an event where the percentage point difference in net capital inflows-to-GDP ratio from the pre-restructuring year to the start of restructuring (from year 0 to year 1), $d_{i, t+1}^{N C I}=100 \times\left(N C I_{i, t+1} / G D P_{i, t+1}-N C I_{i, t} / G D P_{i, t}\right)$ for $R=\{P D$, Weakly, Strictly $\}$, is less than the 25th or 50th percentile among the observations experiencing that type of restructuring. ${ }^{24}$

Figure 8 reports the dynamics of private credit, investment, and GDP for our restructuring strategies (post-default, weakly preemptive, and strictly preemptive) together with restructurings with/without a severe sudden stop. ${ }^{25}$ Private credit, investment, and GDP experiences a more severe decline when a severe sudden stop is accompanied with any of the three types of restructuring strategies (purple lines in Panels A, B, and C). ${ }^{26}$ In contrast, neither private credit investment nor GDP contracts when the restructuring (regardless of its type) is not associated with a severe sudden stop (brown lines in Panels A, B, and C).

\footnotetext{
${ }^{24}$ Calvo et al. (1998) define a sudden stop as a sharp slowdown in net capital inflows. Recent papers broaden this original definition by adding criteria such as (i) the requirement that the stop occurred at the same time as an output contraction in order to exclude positive terms of trade shocks (Calvo et al., 2004), or (ii) the requirement that the stop had to occur in conjunction with a sharp rise in interest rate spreads in order to capture a global component and qualify as a "systemic sudden stop" (Calvo et al., 2008). Focusing on gross flows instead of net flows, Forbes and Warnock (2012) define it a "sudden stop" as a sharp decrease in gross capital inflows.

25 The role of banks' direct exposure channel, i.e., banks' holding of external debt is limited in external debt restructurings. This is shown by both limited changes in banks' holding of sovereign debt and the composition of creditor committee members in external debt restructurungs (Asonuma and Joo 2017).

${ }^{26}$ In strictly preemptive restructurings with a severe sudden stop, investment declines in parallel with a decline in GDP leaving investment-to-GDP ratio steady as shown by the purple line in Panel B (Right) in Figure 8.
} 
Figure 8: Private Credit, Investment, and GDP around Debt Restructurings, with/without Severe Sudden Stops, Average

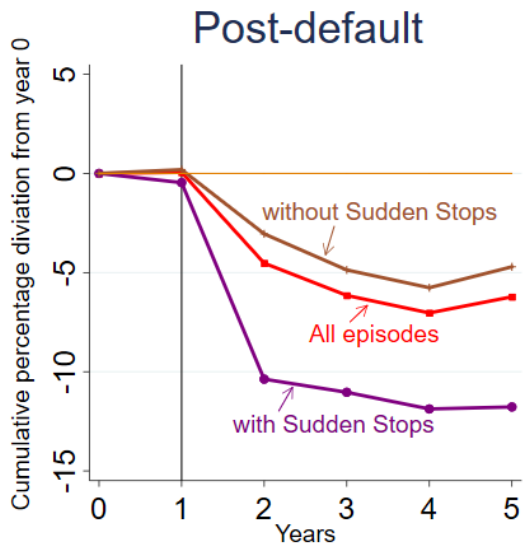

Panel A: Private Credit
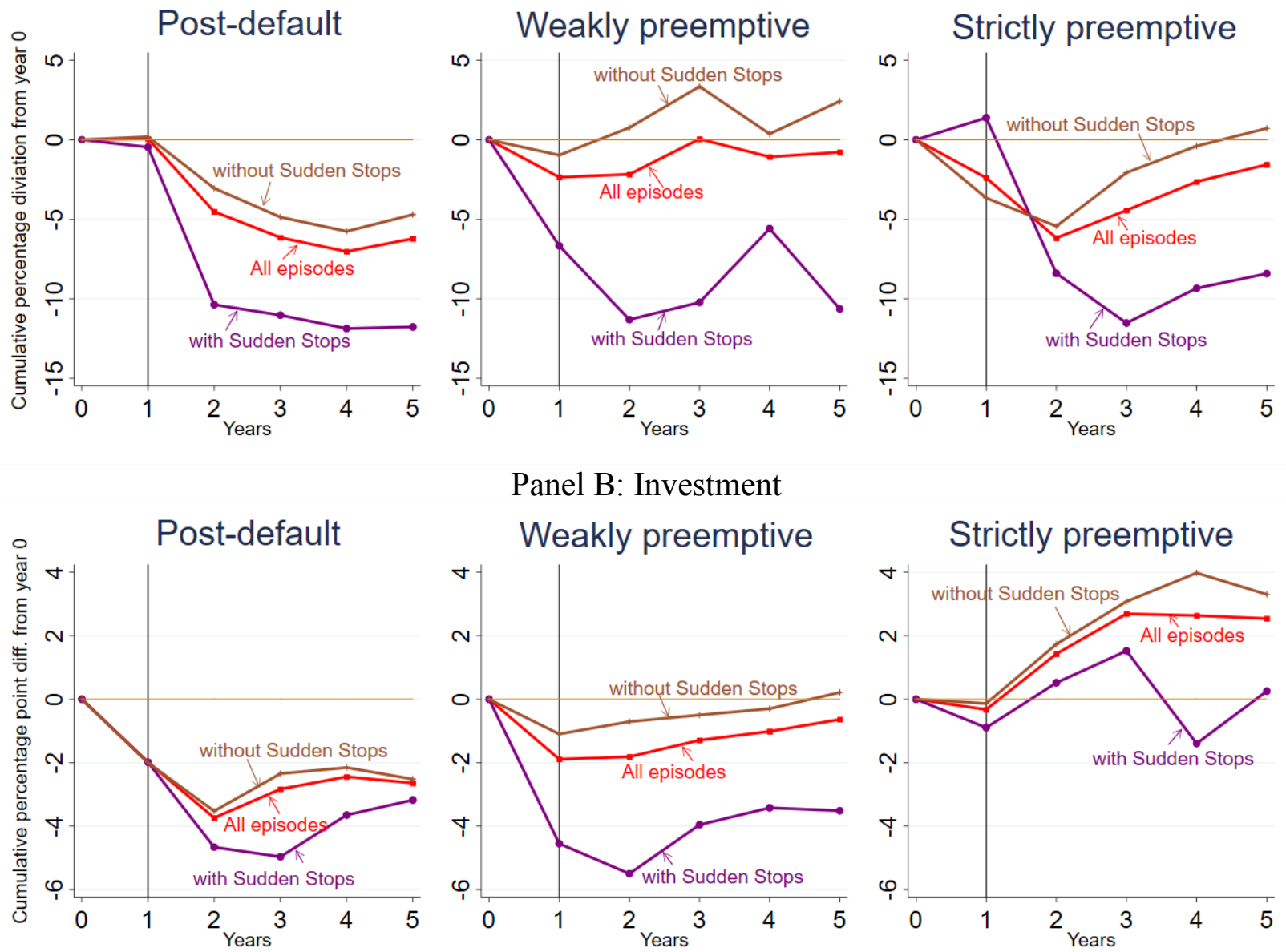

Panel B: Investment
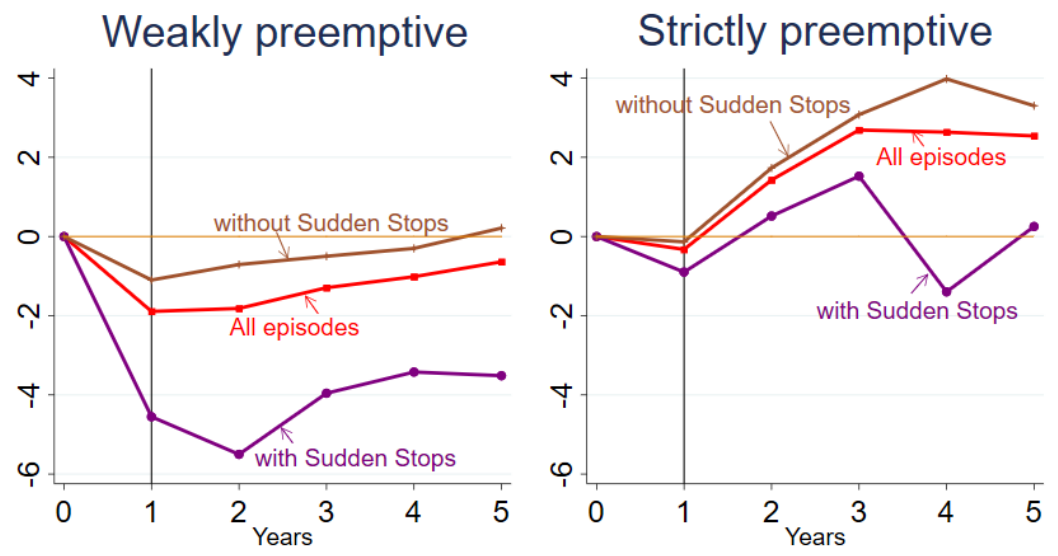

Panel C: GDP
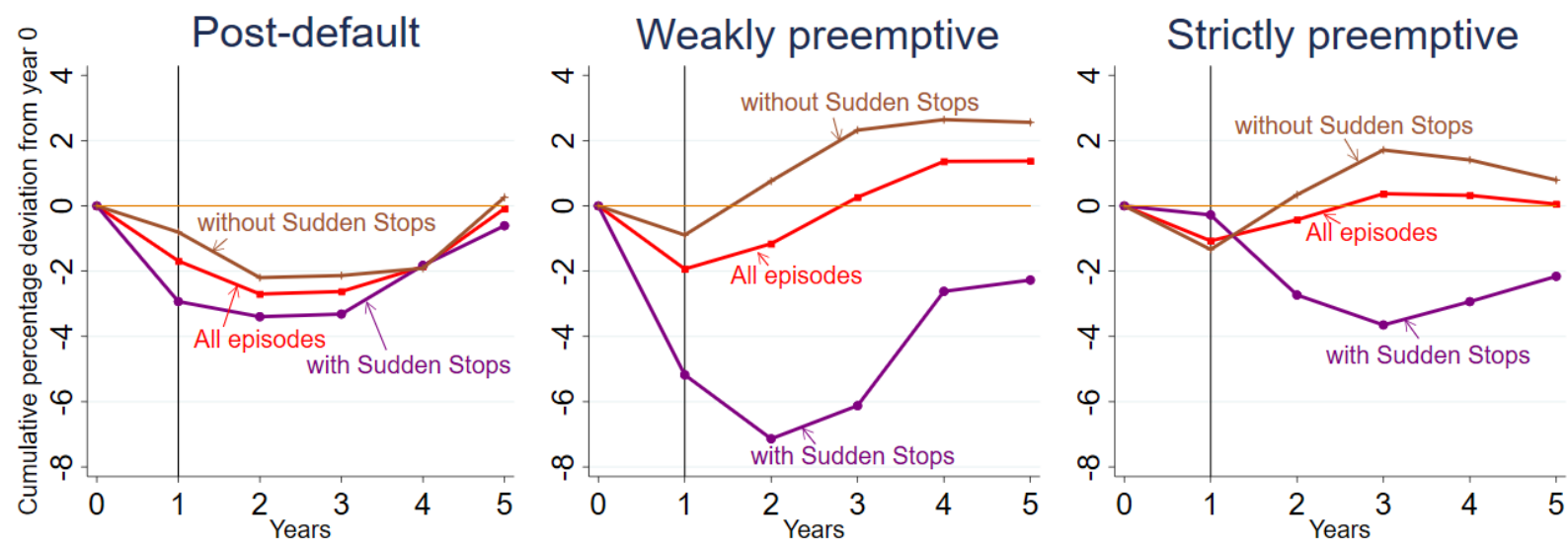

Data Sources: Severe sudden stops are defined as observations where the percentage point difference in the net capital inflows-to-GDP ratio from year 0 to year $1, d_{t+1}^{N C I}=100 *\left(N C I_{i, t+1} / G D P_{i, t+1}-N C I_{i, t} / G D P_{i, t}\right)$, is less than the 25 th percentile of the distribution. The 50th percentile cutoff is employed for the post-default cases in Panel C. Black vertical lines correspond to the start of restructurings $(a t t=1)$. GDP (real) and private credit (real) are detrended using a Hodrick-Prescott filter. Investment is measured as the investment-to-GDP ratio and its percentage point difference from year 0 is shown. 
We analyze how the dynamics of macroeconomic variables differ between restructuring events which were accompanied by a severe sudden stop and those which were not. For this purpose, we follow Jordà and Taylor (2016) and Auerbach and Gorodnichenko (2016) to estimate the impact of a severe sudden stop and specify the following local projection equation:

$$
\begin{gathered}
g_{i, t+h}=\alpha_{i}^{R, h}+\Lambda^{S S, h} D_{i, t+i}^{S S} D_{i, t+1}^{R}+\Lambda^{N o n S S, h}\left(1-D_{i, t+i}^{S S}\right) D_{i, t+1}^{R}+\widetilde{\boldsymbol{X}}_{i, t} \boldsymbol{\beta}^{R . h}+\epsilon_{i, t+h}^{R} \\
\quad \text { for } R=\{P D, \text { Weakly, Strictly }\}, \text { and } h=1,2, \ldots, 5
\end{gathered}
$$

where $D_{i, t+1}^{S S}$ is a dummy variable taking unity if there is a severe sudden stop in year $t+1$ and zero otherwise; $D_{i, t+1}^{R}$ is a dummy variable taking unity if there is a restructuring (for instance, post-default) at year $t+1$ and zero otherwise; $\Lambda^{S S, h}$ and $\Lambda^{\text {NonSS, } h}$ are coefficients to be estimated. In the second term on the right-hand side of equation (5), $D_{i, t+h}^{S}$ is interacted with $D_{i, t+1}^{R}$. Therefore, $\Lambda^{S S, h}$ captures the impact of a severe sudden stop in year $t+1$ associated with a restructuring (for instance post-default) that occurred in the same year, $t+1$. In the third term on the right-hand side of equation (5), $\left(1-D_{i, t+i}^{S S}\right)$ is interacted with $D_{i, t+1}^{R}$. Therefore, $\Lambda^{\text {NonSS }, h}$ reflects the impact when no severe sudden stop is associated with the restructuring that occurred in the same year $t+1$. $\widetilde{\boldsymbol{X}}_{i, t}$ is a set of regressors including cyclical component of log of GDP per capita, lagged changes in the investment-to-GDP ratio, the credit-to-GDP ratio, and the GDP growth rates from period $t$.

In the first stage, we estimate the likelihood of restructurings with and without severe sudden stops, separately for each restructuring strategy, i.e., a "two-type model". In the second stage, using both the predicted dependent variable from (5) and applying the propensity score matching technique, we correct the bias by assigning different weights corresponding to a difference in the estimated probability of events as explained in equation (4). That allows us to compute the average treatment effects of both severe sudden stop and non-severe sudden stop events, respectively.

Panels A, B, and C in Figure 9 (Table D2 in Appendix D.1) report the AIPW estimates for private credit, investment - both in terms of percent of GDP - , and GDP for the three restructuring types, with and without associated severe sudden stops. The solid lines in brown and purple indicate the point estimates for restructurings with and without severe sudden stops, respectively. Gray bands and dotted lines in brown indicate the 95-percent confidence intervals. The horizon for post-default, weakly and strictly preemptive episodes is set to 5, 3, and 3 years, respectively based on the average duration of each restructuring strategy $(5.0,1.1$, and 0.9 years, respectively as reported in Panel A in Table 1). A difference between the lines in brown and purple reflects how private credit, investment or GDP declines due to the associated severe sudden stops for three types of restructurings.

The results for private credit show that the severe sudden stop leads to a significant decline in any type of restructurings (Panel A in Figure 9). Moreover, the decline in private credit due to the severe sudden stop is deeper for post-default than for preemptive restructurings. 
The results for investment and GDP largely mirror those for private credit (Panels B and C in Figure 9). Both investment and GDP continue to point a decline when the restructuring is accompanied by a severe sudden stop, across all three strategies. In parallel with private credit, the decline in investment and GDP due to the severe sudden stop is deeper for post-default than for preemptive restructurings.

Figure 9: Restructurings with/without Severe Sudden Stops, AIPW

Panel A: Private Credit
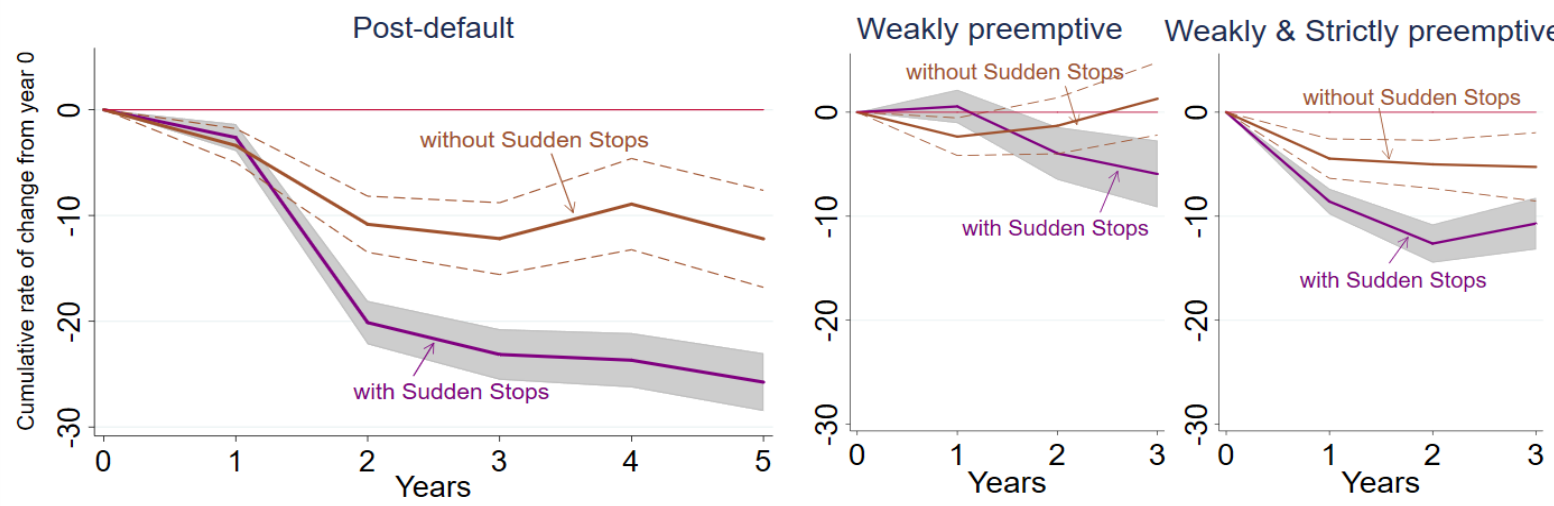

Panel B: Investment
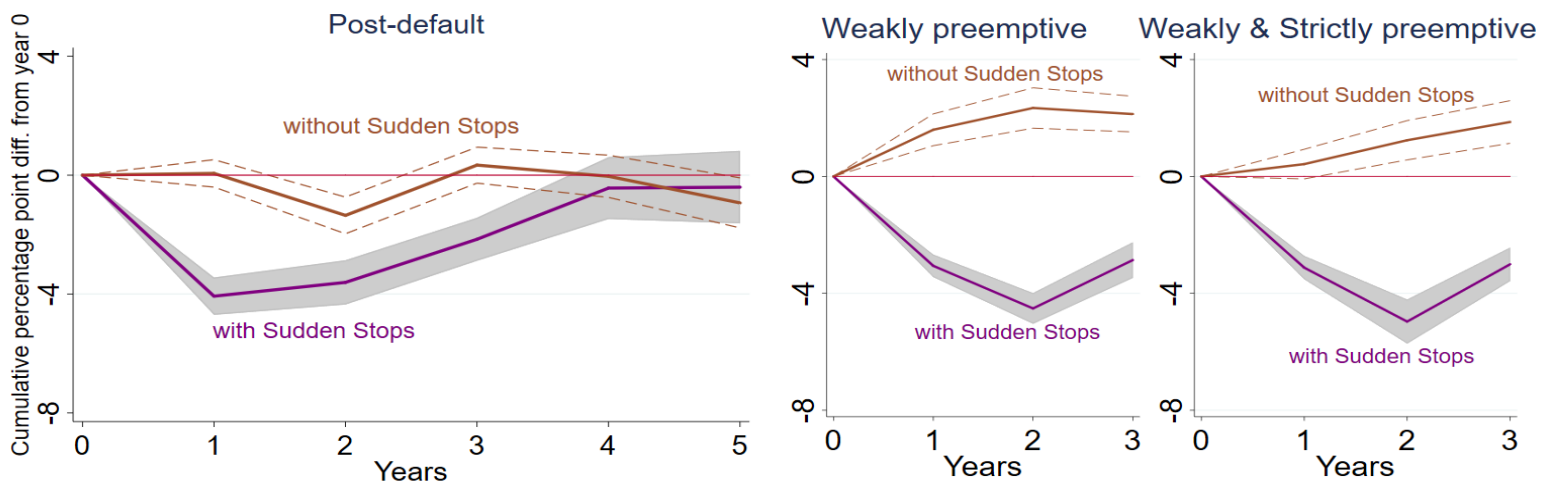

Panel C: GDP
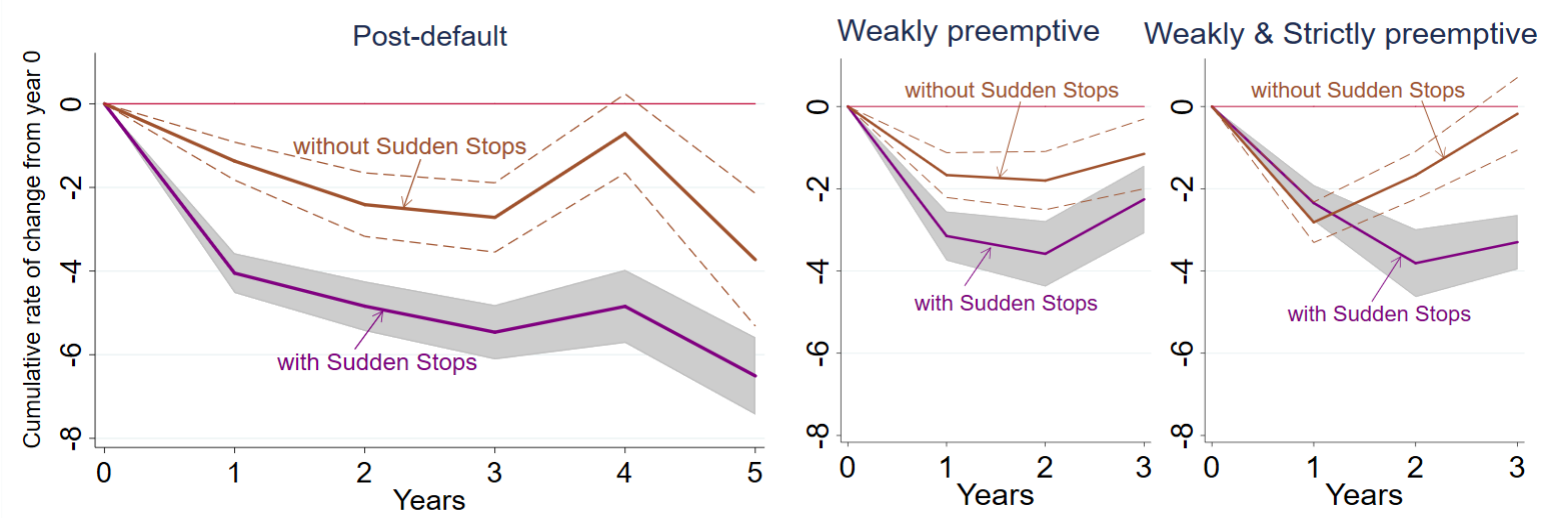

Notes: Severe sudden stops are defined as observations where the percentage point difference in the net capital inflows-to-GDP ratio from year 0 to year $1, d_{t+1}^{N C I}=100 \times\left(N C I_{i, t+1} / G D P_{i, t+1}-N C I_{i, t} / G D P_{i, t}\right)$, is less than the 25th percentile among the observations experiencing that type of restructurings for Panel $A$. The 50th percentile cutoff for Panels $B$ and $C$ in order to have enough number of observations for both groups. The figure shows AIPW estimates of the variable shown in each panel for $h=1,2, \ldots, 5$, where $h$ indicates horizon. Solid lines in brown and purple are point estimates. Gray bands and dotted lines in brown are 95 percent confidence intervals. The sample period is 1970-2013. 
Digging further, Panels A, B, and C in Figure D1 (Table D1) in Appendix D.1 are analogous to those in Figure 9, but report the OLS local projection estimates for private credit, investment, and GDP for the three restructuring types, with and without a severe sudden stop. The severe sudden stop leads to a significant decline in private credit under any type of restructuring (Panel A in Figure D1). Moreover, this also results in a significant decline in both investment and GDP under any type of restructuring (Panels B and C in Figure D1). The declines in private credit, investment, and GDP accompanied with the severe sudden stop are deeper for post-default than for preemptive restructurings. Furthermore, we show that our AIPW estimation results are robust by applying both (i) a one-type model AIPW estimation in Figure D2 (Table D3) in Appendix D.1 and (ii) conventional panel OLS and instrument variable (IV) estimations in Table D4 in the Appendix D.1.

\section{Duration, Haircuts, and Missed Payments}

In this sub-section, we consider whether an additional difference in output cost is incurred depending on the process and settlement of the debt renegotiations (duration and haircuts). In particular, we explore the extent to which a longer restructuring process or a process that delivers larger losses to creditors can explain the dynamics we observe when studying post-default events.

Figure 10: GDP around Debt Restructurings with Short Duration and/or Small Haircuts, Average
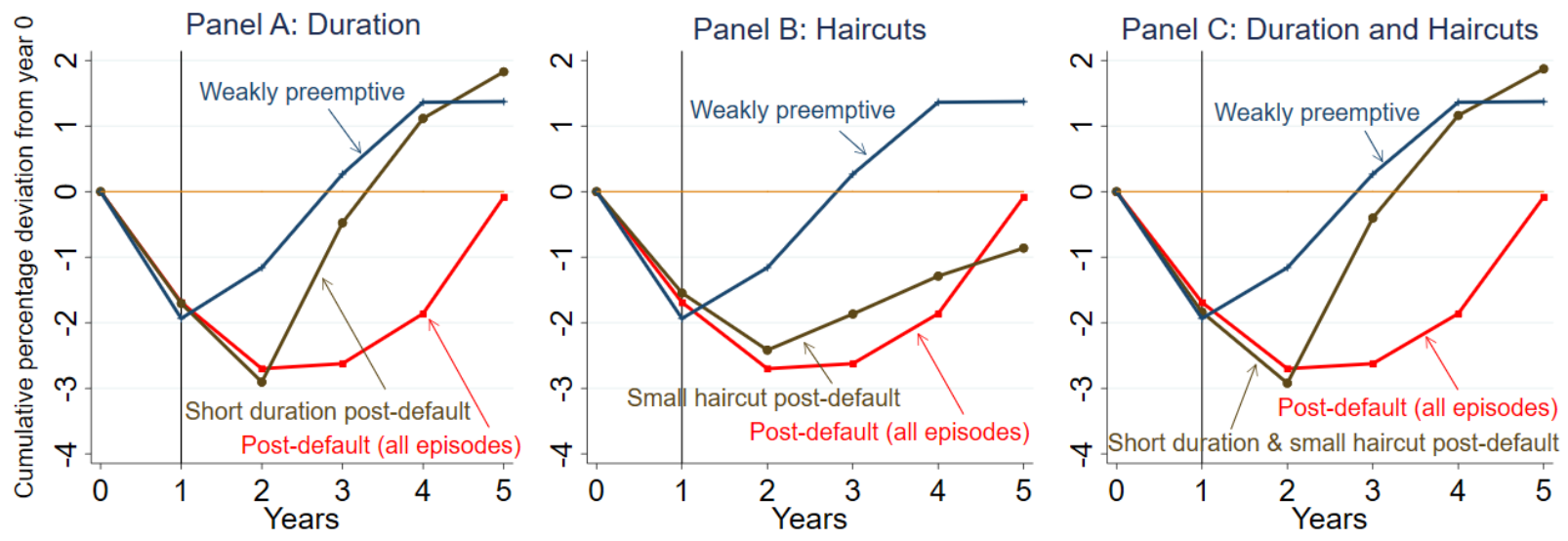
Sources: Asonuma and Trebesch (2016, restructurings, duration), Cruces and Trebesch (2013, haircuts), Penn World
Table 8.0 (Feenstra et al. 2015) (GDP). GDP (real) is measured as a deviation from a Hodrick-Prescott filtered trend.
Black vertical lines correspond to the start of restructurings (at $t=1$ ).

Figure 10 reports the dynamics of GDP for two restructuring strategies (post-default and weakly preemptive) together with "short-duration", "small-haircut" or "short-duration and small haircut" post-default episodes. These correspond to subsamples of post-default cases whose distribution of either duration, haircuts or both duration and haircuts is identical to that of weakly preemptive restructurings. Duration and/or haircuts of episodes drawn from this subsample are on average the same as those drawn from the weakly preemptive sample. We follow the same presentation as in Figure 4. GDP in a short-duration post-default restructuring suffers a similarly sharp decline over the first two years, but then experiences a quick recovery to its pre-crisis level by 
the third year (brown line in Panel A). The adverse effect on GDP of a short-duration post default restructuring seems to fall in between that of a post-default restructuring (red line in Panel A) and that of a weakly preemptive restructuring (blue line in Panel A). It is very close to post-default restructurings in the first two years, but much closer to weakly preemptive restructurings from the third year onwards.

Similarly, GDP experiences a severe decline over the first two years during small-haircut post default restructurings, and it recovers gradually from the third year since the start (brown line in Panel B). The adverse effect on GDP of a small-haircut post-default restructuring falls in between that of a post-default restructuring (red line in Panel B) and that of a weakly preemptive restructuring (blue line in Panel B). A comparison of Panels A and B suggests that shorter duration is more important for achieving better outcomes among post-default restructurings than smaller haircuts (although the two dimensions may be closely related as documented in Benjamin and Wright 2013).

Finally, Panel $\mathrm{C}$ shows the results for a subsample of post-default restructurings with both short duration and low haircuts (brown line). The results for this subsample also lie in between those of the post-default and weakly preemptive restructurings. This pattern suggests that some of the difference in outcomes between post-default and weakly preemptive restructurings stems from the latter's shorter duration (1.1 vs 5 years) and smaller haircuts (18 vs 48 percent). But there are still sizable differences even when we compare the short-duration small-haircut subsample of post-default restructurings with weakly preemptive restructurings, particularly in the 3-5 year horizon. This supports the view that, all else equal, the choice of restructuring strategy per se can have major implications for the medium-term recovery after a restructuring.

We confirm the stylized patterns in Figure 10 in local projection estimates. The actual duration and haircuts involved in a restructuring is only known after that process has unfolded. But the local projection estimates can only use the information set available prior to the start of the restructuring. Thus, we rely on GDP growth forecasts available one year before the start of debt restructurings to differentiate sub-samples based on their expected growth, duration, and haircuts. Post-default restructurings are classified into three sub-groups based only on the available information one year prior to the start of restructurings:

○ Definition vii. A 'post-default restructuring with high (small) GDP growth forecasts', where expected GDP growth is above (below) the mean in post-default restructurings.

o Definition viii. A 'post-default restructuring with long (short) expected duration', where expected duration is above (below) the mean in post-default restructurings.

○ Definition ix. A 'post-default restructuring with high (small) expected haircuts', where expected NPV haircuts are above (below) the mean in post-default restructurings. 
Our classification approach is supported by findings in the theoretical literature on sovereign debt restructurings (Benjamin and Wright 2013; Bi 2008; Yue 2010): the debtor's recovery in capacity of repayment influences both length of restructurings and terms at the settlements. First, we estimate the following regressions on duration and haircuts:

$$
\begin{aligned}
\text { Duration }_{i, t+1} & =\beta_{0}^{D}+\beta_{1}^{D} g_{i, t}^{F, \text { Short }}+\beta_{2}^{D} g_{i, t}^{F, \text { Long }}+Z_{i, t} \beta_{3}^{D}+\epsilon_{i, t+1}^{D}, \\
\text { Haircut }_{i, t+1} & =\beta_{0}^{H}+\beta_{1}^{H} g_{i, t}^{F, \text { Short }}+\beta_{2}^{H} g_{i, t}^{F, \text { Long }}+Z_{i, t} \beta_{3}^{H}+\epsilon_{i, t+1}^{H}
\end{aligned}
$$

${\text { where } \text { Duration }_{i, t+1} \text { and Haircut }}_{i, t+1}$ are duration and haircut (percent) of debt restructuring episode in country $i$ started in year $t+1$, where these take zeros in non-restructuring start years; $g_{i, t}^{F, \text { Short }}$ and $g_{i, t}^{F, \text { Long }}$ are short-term and long-term GDP growth forecasts one year before the start year of restructuring episode $-g_{i, t}^{F, \text { Short }}=g_{i, t}^{F, t+1}$ and $g_{i, t}^{F, \text { Long }}=\sum_{s=t+2}^{t+6} g_{i, t}^{F, s} / 5$ where $g_{i, t}^{F, s}$ denotes the anticipated GDP growth rate in year $s$ forecasted in year $t-; Z_{i, t}$ is a set of controls including cyclical component of log of GDP per capita - accounting for the current business cycle — and number of past post-default and of preemptive restructurings; and $\epsilon_{i, t+1}^{D}$ and $\epsilon_{i, t+1}^{H}$ are error terms. We use GDP growth forecasts from the IMF WEO. In order to avoid a selection bias, we include non-restructuring observations where Duration $_{i, t+1}$ and Haircut $_{i, t+1}$ are set to zeros. Using the predicted duration and haircuts, Duratıon $_{i, t+1}$ and $\widehat{H a r c u}_{i, t+1}$, we define dummy variables for long expected duration and high expected haircuts, $D_{i, t+1}^{\text {LongD }}$ and $D_{i, t+1}^{\text {HighH }}$, taking unity if the predicted duration or haircuts is higher than the $50^{\text {th }}$ percentile and 0 otherwise.

Table 4: Predicting Duration and Haircuts, Poisson

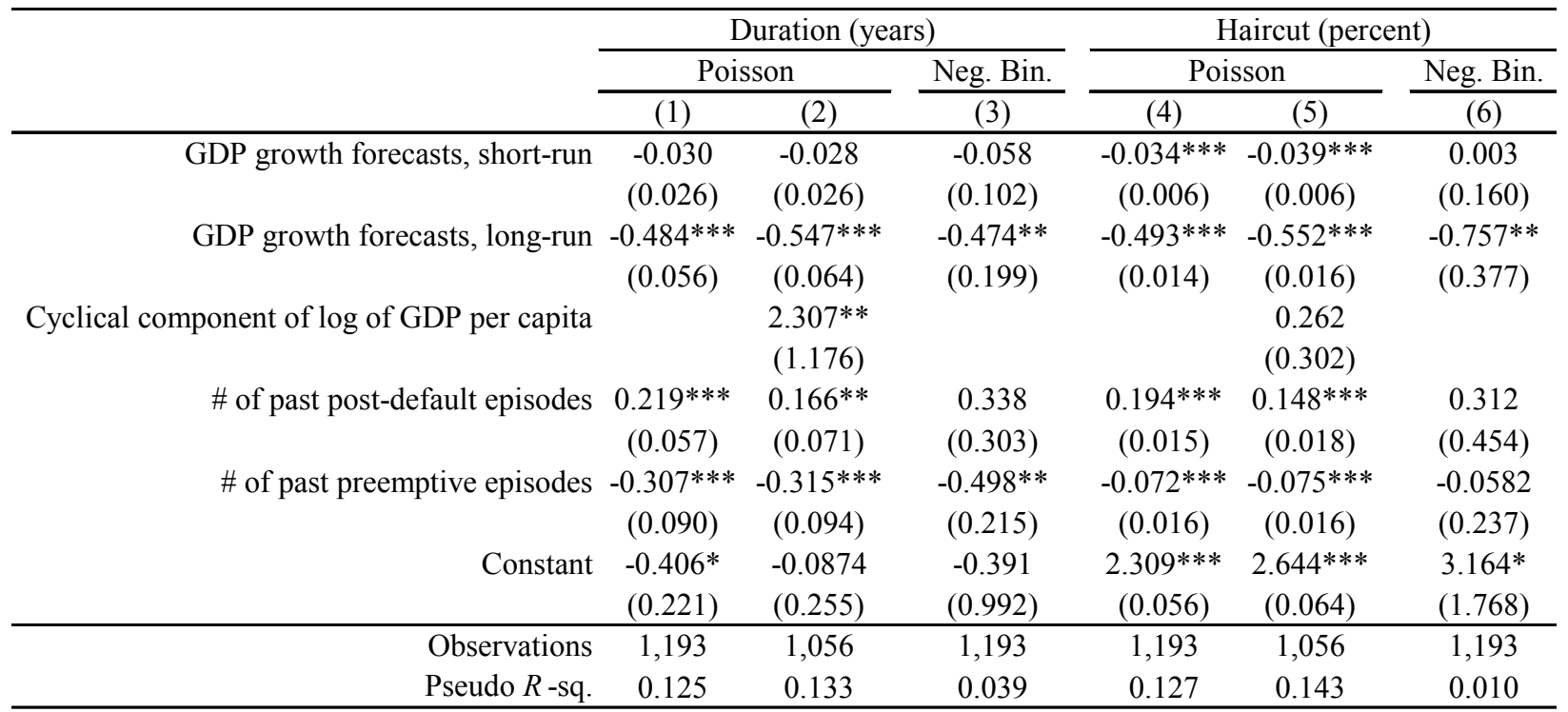

Notes: ${ }^{* *},{ }^{* *}$, and * indicate the statistical significance at 1 percent, 5 percent, and 10 percent level, respectively. Short-run GDP growth forecasts are the expected GDP growth rate in year $t+1$ forecasted in year $t, g_{i, t}^{F, t+1}$. Long-run GDP growth forecasts are the average of GDP growth forecasts over the next five years. For exceptional restructuring cases where haircuts take negative values, these negative values are replaced with zeros. 
Table 4 reports regression results for predicting duration and haircuts. Given that our sample includes non-restructuring observations, we follow the convention in the literature to apply both poisson and negative binominal regressions (Asonuma and Joo 2017). The results show that only high GDP growth forecasts over the long run result in short duration of restructurings. In contrast, both high GDP growth forecasts over the short run and the long run lead to small haircuts (high recovery rates). Past post-default episodes significantly increase both duration and haircuts, while past preemptive episodes significantly decrease both duration and haircuts.

Next, we follow the same approach as in the case of severe sudden stops (equation 5 in Section III.C) to estimate the impact of post-default restructurings with long expected duration and high expected haircuts. We specify the following local projection equation:

$$
\begin{gathered}
g_{i, t+h}=\alpha_{i}^{h}+\Lambda^{\text {Long, } h} D_{i, t+1}^{L o n g D} D_{i, t+1}^{D R}+\Lambda^{\text {Short }, h}\left(1-D_{i, t+1}^{\text {LongD }}\right) D_{i, t+1}^{D R}+\boldsymbol{\beta}^{D R . h}+\varepsilon_{i, t+h}^{D R}, \\
g_{i, t+h}=\alpha_{i}^{h}+\Lambda^{H i g h, h} D_{i, t+1}^{H i g h H} D_{i, t+1}^{D R}+\Lambda^{\text {Small,h}}\left(1-D_{i, t+1}^{H i g h H}\right) D_{i, t+1}^{D R}+\widetilde{\boldsymbol{X}}_{i, t} \boldsymbol{\beta}^{D R . h}+\varepsilon_{i, t+h}^{D R} \\
\text { for } h=1,2, \ldots, 5
\end{gathered}
$$

where $\Lambda^{\text {Long,h }}$ and $\Lambda^{\text {Short,h }}$ are coefficients capturing GDP dynamics for post-default episodes with long and short expected duration, respectively; $\Lambda^{H i g h, h}$ and $\Lambda^{\text {Small,h}}$ are coefficients for post-default episodes with high and small expected haircuts, respectively. We also apply a two type model to estimate the likelihood of post-default episodes with long/short expected duration (high/small expected haircuts), separately to account for differences in macroeconomic conditions in the pre-restructuring year $(t)$. Then, we calculate the average treatment effects of both post-default episodes with long/short expected duration (high/small expected haircuts), respectively, built on the different estimated probability of these events. Thus, the AIPW estimates correct for potential bias in the sub-samples of post-default restructurings driven by pre-restructuring macroeconomic conditions.

Figure 11 reports the AIPW estimates. We follow the same presentation as in Figure 8 . The decline in GDP is more severe and protracted in post-default restructurings with low GDP growth forecasts (Panel A), with long expected duration (Panel B), and with high expected haircuts (Panel C). This last result is in line with findings in Trebesch and Zabel (2017) and Marchesi (2016).

Figure D3 in Appendix D.2 contrasts our baseline AIPW estimation results (Panel A) with results on one-type model AIPW estimation (Panel B) and on OLS local projection estimation (Panel C). The results are qualitatively similar, indicating the robustness of the results across these three approaches.

From a policy perspective, these findings have important implications. Our results suggest that even if a sovereign debtor inevitably needs to default on its debt obligations, i.e., it misses payments, it can still mitigate the adverse effects on GDP, investment, and banking sector by both/either reaching an agreement with its creditors quickly (short duration) and/or inflicting on its creditors the smaller possible losses (small haircuts) needed to restore solvency. 
Figure 11: GDP after Post-default Restructurings, AIPW
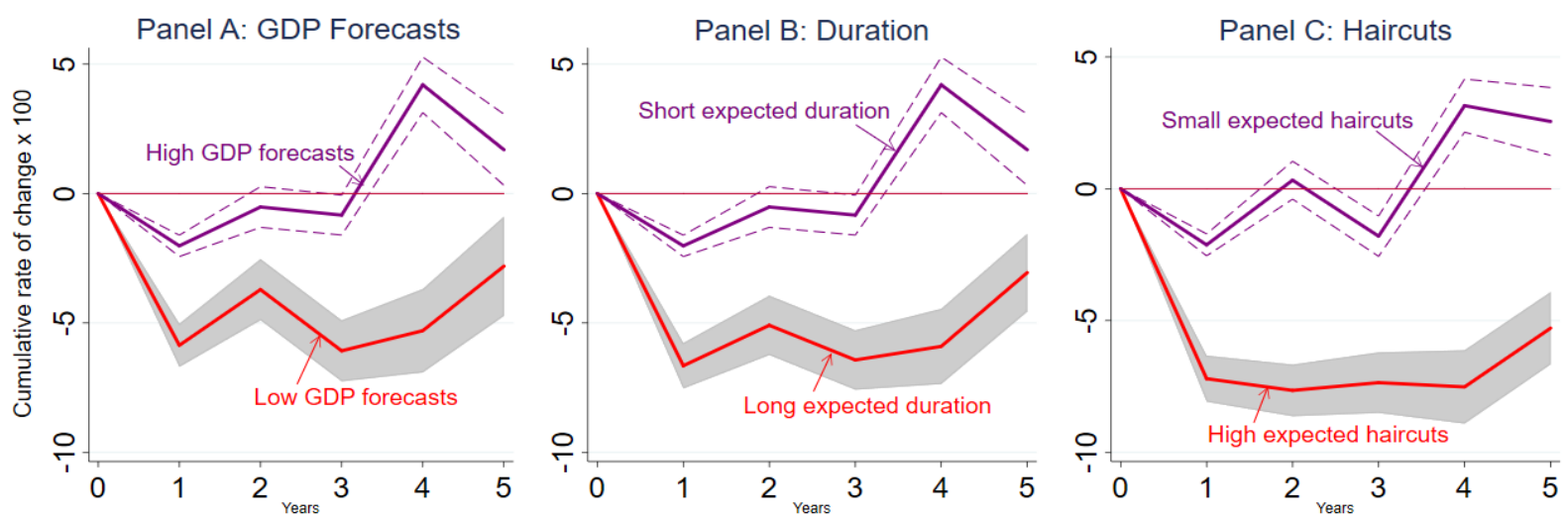

Notes: The figure shows dynamics of GDP after post-default debt restructurings, classifying the sample into those high and low GDP growth forecasts (Panel A), those with short and long expected duration (Panel B), and those with small and high expected haircuts (Panel C). Panel A classifies post-default restructurings into two groups based on the long-run GDP growth forecasts. Panel B and C classify postdefault restructurings into two groups based on the estimated duration and haircuts obtained in columns (2) and (5) in Table 4, respectively. Solid lines in red and purple are point estimates. Gray bands and dotted lines in purple are 95 percent confidence intervals.

\section{Logit APProACH}

Finally, we complement our local projection results by exploring whether banking crises, severe credit and net capital inflow declines are more likely to occur following post-default restructurings. To do so, we apply logit models using restructuring strategies in past years. Our benchmark specification follows Reinhart and Rogoff (2011b) and Balteanu and Erce (2018). While they present multinomial models, we use a bivariate logit approach to study the influence of past restructuring strategies on each of the three events separately. Following the definitions of the three events in Section II.A, we set both the start of debt restructurings at year $\mathrm{t}=1$ and timing of three events as follows: start of banking crisis at year $t=1$ and severe credit and net capital inflow declines over 5 years from $t=0$ to $t=5$. Dummy variables for the three types of restructuring strategies and the three events are set accordingly.

The logit model for banking crises is specified as follows:

$$
\operatorname{Pr}(\text { BankCrisis })_{i, t+1}=\mathbf{G}\left(\widetilde{D}_{i, t-3, t+1}^{P D}, \widetilde{D}_{i, t-3, t+1}^{\text {Weak }}, \widetilde{D}_{i, t-3, t+1}^{\text {Strict }}, \widetilde{\boldsymbol{X}}_{i, t}, \boldsymbol{\alpha}\right)
$$

where $\operatorname{Pr}(\text { BankCrisis })_{i, t+1}$ is the probability that there is a banking crisis in country $i$ in year $t=1$. We explore whether three types of debt restructuring strategies in the previous five years, i.e., from year $t=-3$ to $t=1$ influences the likelihood of banking crisis in the current year. Restructuring dummies $\widetilde{D}_{i, t-3, t+1}^{P D,}, \widetilde{D}_{i, t-3, t+1}^{W e a k}$, and $\widetilde{D}_{i, t-3, t+1}^{\text {Strict }}$ take unity if there is each type of debt restructuring starting during year $t=-3$ to current year $t=1$.

In a similar vein, the logit models for severe credit declines and severe protracted net capital inflow declines are specified as follows: 


$$
\begin{gathered}
\operatorname{Pr}(\text { CreditDecline })_{i, t, t+5}=\boldsymbol{G}\left(D_{i, t+1}^{P D}, D_{i, t+1}^{\text {Weakly }}, D_{i, t+1}^{\text {Strictly }}, \widetilde{\boldsymbol{X}}_{i, t}, \boldsymbol{\alpha}\right), \\
\operatorname{Pr}\left(\text { NCIDecline }_{i, t, t+5}=\boldsymbol{G}\left(D_{i, t+1}^{P D}, D_{i, t+1}^{\text {Weakly }}, D_{i, t+1}^{\text {Strictly }}, \widetilde{\boldsymbol{X}}_{i, t}, \boldsymbol{\alpha}\right)\right.
\end{gathered}
$$

where as defined in Section II.A, $\operatorname{Pr}(\text { CreditDecline })_{i, t, t+5}$ and $\operatorname{Pr}\left(N_{\text {CIDecline }}\right)_{i, t, t+5}$ are the probability that the cumulative percentage point differences in the credit-to-GDP ratio and net capital inflows-to-GDP ratio over five years, $d_{t+5}^{C}=100 *\left(\right.$ Credit $_{i, t+5} / G D P_{i, t+5}-$ Credit $\left._{i, t} / G D P_{i, t}\right)$ are $d_{t+5}^{N C I, D I F}=100 *\left(N C I_{i, t+5} / G D P_{i, t+5}-N C I_{i, t} / G D P_{i, t}\right)$ are less than the 25 th percentile of the distribution (-1.65 and -7.03, respectively). $D_{i, t+1}^{P D}, D_{i, t+1}^{\text {Weakly }}$, and $D_{i, t+1}^{\text {Strictly }}$ are dummy variables taking unity if there is each type of debt restructuring starting at year $t=1$. $\widetilde{\boldsymbol{X}}_{i, t}$ is a vector of control variables at year $t=0$. Note that equations (8) and (9) are identical in terms of both timing of events and time intervals between events and past restructuring strategies. As explained in Section 2.2, we treat each restructuring as an independent eventthere are overlapping observations included in our sample. Following Gourinchas and Obstfeld (2012), we choose current account-to-GDP ratio, foreign reserve-to-GDP ratio, real exchange rate, and GDP growth rate to be included in the set of control variables. Vector $\boldsymbol{\alpha}$ denotes the coefficients to be estimated and $\boldsymbol{G}$ denotes the logistic distribution.

\section{Table 5: Banking Crises and Severe Credit and Net Capital Inflow Declines after Debt

\begin{tabular}{|c|c|c|c|c|c|c|}
\hline & \multicolumn{2}{|c|}{$\begin{array}{c}\text { Banking Crises } \\
\text { at } t=1\end{array}$} & \multicolumn{2}{|c|}{$\begin{array}{l}\text { Severe Credit Declines } \\
\text { cum. from } t=0 \text { to } t=5\end{array}$} & \multicolumn{2}{|c|}{$\begin{array}{c}\text { Severe Net Cap. Inf. Declines } \\
\text { cum. from } t=0 \text { to } t=5\end{array}$} \\
\hline & $\begin{array}{l}\text { Coef. } \\
\text { (Std. err.) }\end{array}$ & $\begin{array}{c}d y / d x \\
\text { (Delta-method } \\
\text { std. err.) }\end{array}$ & $\begin{array}{l}\text { Coef. } \\
\text { (Std. err.) }\end{array}$ & $\begin{array}{c}d y / d x \\
\text { (Delta-method } \\
\text { std. err.) }\end{array}$ & $\begin{array}{c}\text { Coef. } \\
\text { (Std. err.) }\end{array}$ & $\begin{array}{c}d y / d x \\
\text { (Delta-method } \\
\text { std. err.) }\end{array}$ \\
\hline Post-default $1\{t=-3,-2,-1,0,1\}$ & $\begin{array}{c}1.051 * * * \\
(0.279)\end{array}$ & $\begin{array}{c}0.204 * * * \\
(0.075)\end{array}$ & & & & \\
\hline Weakly preemptive $\mathbf{1}\{t=-3,-2,-1,0,1\}$ & $\begin{array}{l}0.910 * * \\
(0.368)\end{array}$ & $\begin{array}{c}0.176^{* *} \\
(0.074)\end{array}$ & & & & \\
\hline Strictly preemptive $\mathbf{1}\{t=-3,-2,-1,0,1\}$ & $\begin{array}{c}0.270 \\
(0.514)\end{array}$ & $\begin{array}{c}0.052 \\
(0.100)\end{array}$ & & & & \\
\hline Post-default $\mathbf{1}\{t=1\}$ & & & $\begin{array}{l}0.812 * * * \\
(0.299)\end{array}$ & $\begin{array}{l}0.179 * * * \\
(0.072)\end{array}$ & $\begin{array}{l}0.704 * * \\
(0.300)\end{array}$ & $\begin{array}{l}0.143 * * \\
(0.065)\end{array}$ \\
\hline Weakly preemptive $\mathbf{1}\{t=1\}$ & & & $\begin{array}{c}0.298 \\
(0.409)\end{array}$ & $\begin{array}{c}0.066 \\
(0.090)\end{array}$ & $\begin{array}{l}0.671 * \\
(0.389)\end{array}$ & $\begin{array}{l}0.137 * \\
(0.080)\end{array}$ \\
\hline Strictly preemptive $\mathbf{1}\{t=1\}$ & & & $\begin{array}{l}-0.419 \\
(0.636)\end{array}$ & $\begin{array}{l}-0.092 \\
(0.142)\end{array}$ & $\begin{array}{l}-1.267 \\
(1.052)\end{array}$ & $\begin{array}{l}-0.258 \\
(0.218)\end{array}$ \\
\hline \multicolumn{7}{|l|}{$\underline{\text { Controls }}$} \\
\hline Current account-to-GDP ratio, lag & $\begin{array}{l}-3.277 \\
(2.339)\end{array}$ & $\begin{array}{l}-0.635 \\
(0.509)\end{array}$ & $\begin{array}{l}-0.178 \\
(1.244)\end{array}$ & $\begin{array}{l}-0.039 \\
(0.276)\end{array}$ & $\begin{array}{c}-6.967 * * * \\
(1.237)\end{array}$ & $\begin{array}{c}-1.418 * * * \\
(0.342)\end{array}$ \\
\hline Foreign reserves-to-GDP ratio, lag & $\begin{array}{c}1.522 \\
(1.850)\end{array}$ & $\begin{array}{c}0.295 \\
(0.363)\end{array}$ & $\begin{array}{l}-2.513 * \\
(1.423)\end{array}$ & $\begin{array}{l}-0.554 * \\
(0.329)\end{array}$ & $\begin{array}{c}4.506 * * * \\
(1.568)\end{array}$ & $\begin{array}{c}0.917 * * * \\
(0.338)\end{array}$ \\
\hline Real exchange rate, log, lag & $\begin{array}{l}-0.337 \\
(0.250)\end{array}$ & $\begin{array}{l}-0.065 \\
(0.033)\end{array}$ & $\begin{array}{l}-0.111 \\
(0.141)\end{array}$ & $\begin{array}{l}-0.025 \\
(0.027)\end{array}$ & $\begin{array}{l}-0.238 * \\
(0.134)\end{array}$ & $\begin{array}{l}-0.048^{*} \\
(0.020)\end{array}$ \\
\hline GDP growth rate, lag & $\begin{array}{l}-1.798 \\
(2.090) \\
\end{array}$ & $\begin{array}{l}-0.349 \\
(0.410) \\
\end{array}$ & $\begin{array}{c}-6.453 * * * \\
(1.226) \\
\end{array}$ & $\begin{array}{c}-1.423 * * * \\
(0.330) \\
\end{array}$ & $\begin{array}{c}2.648 * * \\
(1.201) \\
\end{array}$ & $\begin{array}{c}0.538 * * \\
(0.257) \\
\end{array}$ \\
\hline Country fixed effects & \multicolumn{2}{|c|}{ Yes } & \multicolumn{2}{|c|}{ Yes } & \multicolumn{2}{|c|}{ Yes } \\
\hline $\begin{array}{r}\text { Log-likelihood ratio } \\
(p \text {-value }) \\
\text { Pseudo } R \text {-squared }\end{array}$ & & & & & & \\
\hline $\begin{array}{r}\text { Number of observations } \\
\text { Number of countries }\end{array}$ & \multicolumn{2}{|c|}{1,129} & \multicolumn{2}{|c|}{1,284} & \multicolumn{2}{|c|}{1,474} \\
\hline
\end{tabular} Restructurings, Logit}

Notes: The debt restructuring dummies take unity at the start of restructurings. All regressions include a constant term and country fixed effects. The sample period is $1970-2013 .{ }^{* * *},{ }^{* *}$, and * indicate the statistical significance at 1 percent, 5 percent, and 10 percent level, respectively. Standard errors are in parentheses. The data on debt restructurings come from Asonuma and Trebesch (2016) and the data on banking crises come from Laeven and Valencia (2013). 
Table 5 reports the logit regression results. For countries which have experienced post-default restructurings in the previous years, a banking crisis occur more likely-quantitatively 20 percent in column ( $\left.1^{\prime}\right)$ - than for those experiencing a preemptive (weakly or strictly) restructuring. Similarly, countries which have experienced post-default restructurings are more likely to suffer a severe credit decline and severe net capital inflow decline in the following years-quantitatively 18 and 14 percent, respectively. The other control variables have the expected signs. Severe net capital inflow declines are associated with large current account deficits and real exchange rate depreciations, and banking crises and severe credit declines are followed by real exchange rate depreciations - both are consistent with the literature (e.g., Reinhart and Rogoff 2009; Kaminsky and Reinhart 1999). Lastly, the GDP growth rate has a negative sign indicating that financial crises occur during a recession.

\section{Conclusion}

In this paper, we shed new light on the growing empirical literature on the costs of sovereign debt restructurings, by exploring output and banking sector costs, and linking them to the restructuring strategies chosen by the sovereign. We show that the transmission channels and associated output and banking sector costs depend on whether the restructuring takes place preemptively (without missing payments to creditors), or after a default has occurred (and payments are unilaterally missed). Our local projection estimates show a large decline in GDP and investment, amplified by severe sudden stops and transmitted through a "capital flow-credit channel"- - supported by both an increase in lending interest rates and declines in credit and capital inflows.

Our key finding suggests that countries that succeed in a restructuring without missing payments to creditors are largely able to avoid, or at least mitigate both output and banking sector costs associated with restructuring. Though that approach can lead to better outcomes, in practice countries can face several constraints on the choice of how to restructure. For instance, they may be hit by the sudden realization of a large shock or they may find themselves in the "bad equilibrium" in a multiple-equilibria context. Depending on their situation, they might have no choice but to stop servicing their debt without some immediate debt relief. But even then, instances where the suspension of payments is decided quickly in collaboration with creditors are still associated with better outcomes than when payments are suspended unilaterally by the debtor. Smaller haircuts i.e., creditor-friendly terms also tend to be associated with better outcomes. But the haircut offered should be large enough to restore solvency (offering a small haircut which eventually requires another restructuring is likely to be counter-productive, and lead to even higher costs).

Our findings have implications for the ongoing discussion on how to best resolve sovereign debt crises. The real economy, the financial sector and the government are all interconnected. When designing a debt restructuring strategy, it is crucial to understand the spillover and feedback channels that the restructuring can have on the domestic financial system. Much of the output 
costs hinge on whether a severe sudden stop can be avoided, which is more likely in a preemptive restructuring.

Moreover, our results show that, even if sovereign's debt has fallen into arrears, a sovereign can still minimize the output costs of the default by reaching a restructuring agreement rapidly. Relatedly, our findings also have implications for the design of official financing, suggesting that where feasible, long-run costs can be attenuated if official financing and creditor cooperation allow countries to restructure without missing payments. It also highlights the costs that countries can face for trying to delay adjustment (and requests for official support) until a default becomes inevitable. These should be important considerations in the design of future debt restructuring strategies. 


\section{References}

Acharya, V. V., T. Eisert, C. Eufinger, and C. Hirsch, 2015, "Real Effects of the Sovereign Debt Crisis in Europe: Evidence from Syndicated Loans,” CEPR Discussion Paper 10108.

Angrist, J. D., Ó. Jordá, and G. M. Kuersteiner, 2016, "Semiparametric Estimates of Monetary Policy Effects: String Theory Revisited," forthcoming in Journal of Business \& Economic Statistics.

Arellano, C., Y. Bai and L. Bocola, 2017, "Sovereign Default Risk and Firm Heterogeneity," Federal Reserve Bank of Minneapolis Research Department Staff Report 547.

Arteta, C., and G. Hale, 2008, "Sovereign Debt Crises and Credit to the Private Sector," Journal of International Economics, Vol.74(1), pp. 53-69.

Asonuma, T., 2016, "Serial Sovereign Defaults and Debt Restructurings," IMF Working Paper $16 / 66$.

Asonuma, T., M. Chamon, and A. Sasahara, 2016, “Trade Costs of Sovereign Debt Restructurings: Does a Market-Friendly Approach Improve the Outcome?” IMF Working Paper 16/222.

Asonuma, T., and H. Joo, 2017, "Sovereign Debt Restructurings: Delays in Renegotiations and Risk Averse Creditors," Manuscript, IMF.

Asonuma, T., and M. G. Papaioannou, 2016, "Domestic Sovereign Debt Restructurings: Processes, Outcomes, and Challenges," Manuscript, IMF.

Asonuma, T., and C. Trebesch, 2016, "Sovereign Debt Restructurings: Preemptive or Postdefault," Journal of the European Economic Association, Vol.14(1), pp. 175-214.

Auerbach, A., and Y. Gorodnichenko, 2016, "Effects of Fiscal Shocks in a Globalized World," IMF Economic Review, Vol.64(1), pp. 177-215.

Bai, Y., and J. Zhang, 2012, “Duration of Sovereign Debt Renegotiation,” Journal of International Economics, Vol.86(2), pp. 252-268.

Balteanu, I., and A. Erce, 2018, "Linking Bank Crises and Sovereign Defaults: Evidence from Emerging Markets," IMF Economic Review, Vol.66(4), pp. 617-664.

Benjamin, D., and M. L. J. Wright, 2013, "Recovery Before Redemption? A Theory of Delays in Sovereign Debt Renegotiations." Manuscript, Federal Reserve Bank of Chicago and State University of New York at Buffalo.

Bernanke, B. S., and C. S. Lown, 1991, "The Credit Crunch," Brookings Papers on Economic Activity, Vol.22(2), pp. 205-248.

Bi, R., 2008, ““Beneficial” Delays in Debt Restructuring Negotiations,” IMF Working Paper $08 / 38$.

Bianchi, J., S. Lizarazo, and H. Sapriza, 2013, "Bailout Guarantees, Banking Crises and Sovereign Debt Crises," Manuscript, Board of Governors of the Federal Reserve System, Federal Reserve Bank of Philadelphia, and IMF. 
Bocola, L., 2015, “The Pass-Through of Sovereign Risk," Federal Reserve Bank of Minneapolis Working Paper 722.

Bolton, P., and O. Jeanne, 2011, "Sovereign Default Risk and Bank Fragility in Financially Integrated Economies," IMF Economic Review, Vol.59(2), pp. 162-194.

Borensztein, E., and U. Panizza, 2009, “The Costs of Sovereign Default,” IMF Staff Papers, Vol. 56(4), pp. 683-741.

Boz, E., P. D’Erasmo, and B. Durdu, 2016, “Sovereign Risk and Bank Balance Sheets: The Role of Macroprudential Policies," Manuscript, Board of Governors of the Federal Reserve System, Federal Reserve Bank of Philadelphia, and IMF.

Broner, F., T. Didier, A. Erce, and S. L. Schmukler, 2013, "Gross Capital Flows: Dynamics and Crises,” Journal of Monetary Economics, Vol.60(1), pp. 113-133.

Brookings Committee on International Economic Policy and Reform (CEIPR), 2013, "Revisiting Sovereign Bankruptcy," Brookings Institution, October.

Bulow, J., and K. Rogoff, 1989, “Sovereign Debt: Is to Forgive or to Forget?” American Economic Review, Vol.79(1), pp. 43-50.

Calvo, G., 1998, "Capital Flows and Capital-market Crises: the Simple Economics of Sudden Stops. Journal of Applied Economics Vol.1(1), pp. 35-54.

Calvo, G., A. Izquierdo, and L. F., Mejía, 2004, "On the Empirics of Sudden Stops: the Relevance of Balance-sheet Effects," NBER Working Paper 10520.

Calvo, G., A. Izquierdo, and L. F., Mejía, 2008. Systemic Sudden Stops: the Relevance of Balance-sheet Effects and Financial Integration. NBER Working Paper 14026

Chari, A., R. Leary, and T. Phan, 2018, "The Costs of (sub)Sovereign Default Risk: Evidence from Puerto Rico," Federal Reserve Bank of Richmond WP 18-03.

Cesa-Bianchi, A., A. Ferrero, and A. Rebucchi, 2017, "International Credit Supply Shocks," Journal of International Economics, Vol.112(C), pp. 219-237.

Cheng G., J. Diaz-Cassou, and A. Erce, 2018, “The Macroeconomic Effects of Official Debt Restructuring: Evidence from the Paris Club," Oxford Economic Papers, pp. 1-20.

Clair, R. T., and P. Tucker, 1993, "Six Causes of the Credit Crunch (Or, Why Is It So Hard to Get a Loan?)," Federal Reserve Bank of Dallas Economic Review, Third Quarter 1993, pp. 1-19.

Cole, H., and P. Kehoe, 2000, “Self-Fulfilling Debt Crises,” Review of Economic Studies, Vol.67, pp. 91-116.

Cruces, J., and C. Trebesch, 2013, "Sovereign Defaults: The Price of Haircuts," American Economic Journal: Macroeconomics, Vol.5(3), pp. 85-117.

Das, U., M. Papaioannou, C. Trebesch, 2011, "Spillovers of Sovereign Default Risk: How Much is the Private Sector Affected?" In Sovereign Debt: From Safety to Default, edited by R.W. Kolb, pp. 33-41, John Wiley \& Sons, Inc. 
Das, U., M. Papaioannou, and C. Trebesch, 2012, "Sovereign Debt Restructurings 1950-2010: Literature Survey, Data, and Stylized Facts," IMF Working Paper 12/203.

De Paoli, B., G. Hoggarth, and V. Saporta, 2009, "Output Costs of Sovereign Crises: Some Empirical Estimates," Bank of England Working Paper 362.

Diaz-Cassou, J., A. Erce, and J. Vazquez-Zamora, 2008, "Recent Episodes of Sovereign Debt Restructurings. A Case-study Approach,” Banco de España Occasional Paper 0804.

Enderlein, H., C. Trebesch, and L. von Daniels, 2012, "Sovereign Debt Disputes: A Database on Government Coerciveness during Debt Crises," Journal of International Money and Finance, Vol.31(2), pp. 250-266.

Engler, P., and C. Große Steffen, 2016, "Sovereign Risk, Interbank Freezes, and Aggregate Fluctuations," European Economic Review, Vol.87, pp. 34-61.

Erce, A. 2014, "Sovereign Debt Restructurings and the IMF: Implications for Future Official Interventions", Federal Reserve of Dallas, Globalization and Monetary Policy Institute, Working Paper 143.

Erce, A., and E. Mallucci, 2018, "Selective Sovereign Defaults," Manuscript, Board of Governors of the Federal Reserve System and European Stability Mechanism.

Fakos, A., P. Sakellaris, and T. Tavares, 2018, "Investment Slumps during Financial Crises: The Role of Credit Constraints," Manuscript, Athens University of Economics and Business and ITAM.

Feenstra, R. C., R. Inklaar, and M. P. Timmer, 2015, "The Next Generation of the Penn World Table," American Economic Review, Vol.105(10), pp. 3150-3182.

Fernandez, R., and A. Martin, 2014, "The Long and the Short of It: Sovereign Debt Crises and Debt Maturity," NBER Working Paper 20786.

Forbes, K., and F. E. Warnock, 2012, “Capital Flow Waves: Surges, Stops, Flight, and Retrenchment," Journal of International Economics, Vol.88(2), pp. 235-251.

Forni, L., G. Palomba, J. Pereira and C. Richmond, 2016, "Sovereign Debt Restructuring and Growth," IMF Working Paper 16/147.

Furceri, D., and A. Zdzienicka, 2012, "How Costly Are Debt Crises?” Journal of International Money and Finance, Vol.31(4), pp. 726-742.

Gennaioli, N., A. Martin, and S. Rossi, 2014, "Sovereign default, Domestic Banks, and Financial Institutions," The Journal of Finance, Vol.69(2), pp. 819-866.

Gennaioli, N., A. Martin, and S. Rossi, 2018, "Banks, Government Bonds, and Default: What do the Data Say?” Journal of Monetary Economics, Vol.98, pp. 98-113.

Gordon, G., and P. Guerron-Quintana, 2018, "Dynamics of Investment, Debt and Default," Review of Economic Dynamics, Vol.28, pp. 71-85.

Gornemann, N., 2014, "Sovereign Default, Private Investment, and Economic Growth," Manuscript, Board of Governors of the Federal Reserve System. 
Gourinchas, P. O., and M. Obstfeld, 2012, "Stories of the Twentieth Century for the TwentyFirst," American Economic Journal: Macroeconomics, Vol.4(1), pp. 226-265.

Hahm, J. H., H. S. Shin, and K. Shin, 2013, "Noncore Bank Liabilities and Financial Vulnerability," Journal of Money, Credit and Banking, Vol.45, No.1, pp. 3-36.

Hébert, B., and J. Schreger, 2017, “The Costs of Sovereign Default: Evidence from Argentina," American Economic Review, Vol.107(10), pp. 3119-3145.

Ilzetzki, E. O, C. M. Reinhart, and K. Rogoff, 2015, "Exchange Rate Arrangements into the 21st Century: Will the Anchor Currency Hold?” Working paper, Harvard University.

International Monetary Fund (IMF), 2014, “The Fund's Lending Framework and Sovereign Debt_-Preliminary Considerations," Policy Paper, June (Washington: International Monetary Fund).

International Monetary Fund (IMF), 2015, “The Fund's Lending Framework and Sovereign Debt-Further Considerations," Policy Paper, April (Washington: International Monetary Fund).

International Monetary Fund (IMF), 2016, International Financial Statistics, 1948-2016.

International Monetary Fund (IMF), 2017, World Economic Outlook. April.

Jordá, Ó., 2005, “Estimation and Inference of Impulse Responses by Local Projections," American Economic Review, Vol.95(1), pp.161-182.

Jordá, Ó., M. Schularick, and A. M. Taylor, 2013, "When Credit Bites Back," Journal of Money, Credit and Banking, Vol.45(2), pp. 3-28.

Jordá, Ó., M. Schularick, and A. M. Taylor,2016, "Sovereigns versus Banks: Credit, Crises, and Consequences," Journal of the European Economic Association, Vol.14(1), pp. 45-79.

Jordá, Ó. and A. M. Taylor, 2016, "The Time for Austerity: Estimating the Average Treatment Effect of Fiscal Policy,” The Economic Journal Vol.126(590), pp. 219-255.

Kaminsky, G. L. and C. M. Reinhart, 1999, “The Twin Crises: The Causes of Banking and Balance-of-Payments Problems," American Economic Review, Vol 89(3), pp. 473-500.

Kaminsky, G. L., and P. Vega-García, 2016, "Systemic and Idiosyncratic Sovereign Debt Crises," Journal of the European Economic Association, Vol.14(1), pp. 80-114.

Kuvshinov, D., and K. Zimmermann, 2016, "Sovereign Going Bust: Estimating the Cost of Default," University of Bonn Discussion Paper 01/2016.

Laeven, L., and F. Valencia, 2013, "Systemic Banking Crises Database" IMF Economic Review, Vol.61(2), pp. 225-270.

Levy-Yeyati, E., and U. Panizza, 2011, “The Elusive Costs of Sovereign Defaults," Journal of Development Economics, Vol.94(1), pp. 95-105.

Mallucci, E., 2015, "Domestic Debt and Sovereign Defaults," Board of Governors of the Federal Reserve System International Finance Discussion Paper, 1153. 
Marchesi, S., 2016, "Life after default? Private vs. Official Sovereign Debt Restructurings, Development Working Papers 398, Centro Studi Luca d'Agliano, University of Milano.

Mariscal, R., A. Powell, G. Sandleris, and P. Tavella, 2015, "Sovereign Defaults: Has the Current System Resulted in Last (Re)solutions?" Universidad Torcuato Di Tella Business School Working Papers 2015-03.

Mendoza, E. G., and V. Z. Yue, 2012, "A General Equilibrium Model of Sovereign Default and Business Cycles," Quarterly Journal of Economics, Vol.127(2), pp. 889-946.

Panizza, U., F. Sturzenegger, and J. Zettelmeyer, 2009, “The Economics and Law of Sovereign Debt and Default," Journal of Economic Literature, Vol.47(3), pp. 651-698.

Park, J., 2017, "Sovereign Default and Capital Accumulation," Journal of International Economics, Vol.106, pp. 119-133.

Pei, Y., 2016, “Optimal Sovereign Defaults in the Presence of Financial Frictions," Manuscript, State University of New York at Buffalo.

Perez, D. J., 2015, "Sovereign Debt, Domestic Banks and the Provision of Public Liquidity," Manuscript, NYU.

Reinhart, C. M., V. Reinhart, C. Trebesch, 2016, "Global Cycles: Capital Flows, Commodities, and Sovereign Default, 1815-2015," American Economic Review: Papers \& Proceedings, Vol.106(5), pp. 574-580.

Reinhart, M. C., and K. Rogoff, 2009, This Time is Different: Eight Centuries of Financial Folly, Princeton University Press.

Reinhart, M. C., and K. Rogoff, 2011a, “The Forgotten History of Domestic Debt," The Economic Journal, Vol.121(552), pp. 319-350.

Reinhart, M. C., and K. Rogoff, 2011b, "From Financial Crash to Debt Crisis" American Economic Review, Vol.101(5), pp. 1676-1706.

Reinhart, M. C., K. Rogoff, and M. A. Savastano, 2003, “Debt Intolerance,” Brookings Papers on Economic Activity, Vol.34(1), pp. 1-74.

Robins, J. M., A. Rotnitzky, and L. P. Zhao, 1994, "Estimation of Regression Coefficients When Some Regressors Are Not Always Observed," Journal of the American Statistical Association, Vol. 89(427), pp. 846-866.

Roldan-Pena, J., 2012, "Default Risk and Economic Activity: A Small Open Economy Model with Sovereign Debt and Default,” Banco Central de Mexico Working Paper 2012-16.

Sandleris, G., 2014, "Sovereign Defaults, Credit to the Private Sector, and Domestic Credit Market Institutions," Journal of Money, Credit and Banking, Vol.46(2-3), pp. 321-345.

Sandleris, G., and M. L. J. Wright, 2014, "The Costs of Financial Crises: Resource Misallocation, Productivity, and Welfare in the 2001 Argentine Crisis," The Scandinavian Journal of Economics, Vol.116(1), pp. 87-127. 
Schularick, M., and A. M. Taylor, 2012, "Credit Booms Gone Bust: Monetary Policy, Leverage Cycles and Financial Crises, 1870-2008," American Economic Review, Vol.102(2), pp. 1029-1061.

Sosa-Padilla, C., 2018, “Sovereign Defaults and Banking Crises," Journal of Monetary Economics, Vol.99, pp. 88-105.

Standard and Poor's, 2006, “Default Study: Sovereign Defaults At 26-Year Low, To Show Little Change In 2007," September 18, 2006.

Sturzenegger, F., 2004, “Tools for the Analysis of Debt Problems," Journal of Restructuring Finance, Vol.1(1), pp. 201-223.

Sturzenegger, F., and J. Zettelmeyer, 2006, Debt Defaults and Lessons from a Decade of Crises, MIT Press.

Sturzenegger, F., and J. Zettelmeyer, 2008, "Haircuts: Estimating Investors Losses in Sovereign Debt Restructurings, 1998-2005," Journal of International Money and Finance, Vol.27(5), pp. 780-805.

Tomz, M., and M. L. J. Wright, 2007, “Do Countries Default in "Bad” Times?” Journal of the European Economic Association, Vol.5(2-3), pp. 352-360.

Trebesch, C., and M. Zabel, 2017, "The Output Costs of Hard and Soft Sovereign Default," European Economic Review, Vol.92, pp.416-432.

World Bank (WB), 2016a, Global Financial Development Database.

World Bank (WB), 2016b. World Development Indicators.

Yue, V., 2010, “Sovereign Default and Debt Renegotiation,” Journal of International Economics, Vol.80(2), pp.176-187. 


\section{Appendix A. Data}

\section{A.1. Sample Countries}

The dataset includes only countries that experienced debt restructurings. Among them, 60 countries experienced 111 episodes of post-default debt restructuring between 1978 and 2010:

Albania, Algeria, Argentina, Bolivia, Bosnia and Herzegovina, Brazil, Bulgaria, Cameroon, Congo Rep., Costa Rica, Cote d'Ivoire, Croatia, Cuba, Dominican Republic, Ecuador, Ethiopia, Gabon, the Gambia, Guinea, Guyana, Honduras, Iraq, Jamaica, Jordan, Kenya, Liberia, Macedonia (FYR), Madagascar, Malawi, Mauritania, Moldova, Morocco, Mozambique, Nicaragua, Niger, Nigeria, Pakistan, Panama, Paraguay, Peru, the Philippines, Poland, Romania, Russian Federation, Sao Tome and Principe, Senegal, Serbia and Montenegro, Seychelles, Sierra Leone, Slovenia, Sudan, Tanzania, Togo, Turkey, Uganda, Venezuela, Vietnam, Yemen, Rep. of, Zaire, and Zambia

26 countries experienced 46 episodes of weakly preemptive debt restructuring:

Argentina, Belize, Brazil, Chile, Dominica, Dominican Republic, Ecuador, Grenada, Jamaica, Nigeria, Malawi, Mexico, Morocco, Niger, Panama, Peru, the Philippines, Romania, Senegal, South Africa, Trinidad and Tobago, Turkey, Ukraine, Uruguay, Venezuela, and Yugoslavia

13 countries experienced 23 episodes of strictly preemptive debt restructuring:

Algeria, Chile, Dominican Republic, Jamaica, Mexico, Moldova, Nicaragua, Pakistan, Peru, South Africa, Ukraine, Uruguay, and Yugoslavia

\section{A.2. Data Sources}

\section{Variable}

- Private external debt restructuring data

- Banking crisis data

- Terms of trade

- Population

- Openness

- Investment

- Real exchange rates

- Real GDP, US-dollar denominated

- Real GDP per capita

- Real GDP growth rates

\section{Data source}

Asonuma and Trebesch (2016)

Laeven and Valencia (2013)

PWT 8.0

WDI (World Bank, 2016a)

Authors' calculation based on PWT 8.0 data

WDI (World Bank, 2016a)

IMF International Financial Statistics

WDI (World Bank, 2016a)

WDI (World Bank, 2016a)

Authors' calculation based on WDI (World Bank, 2016a) 
- Cyclical component of real GDP per capita

- Private credit (real)

- Lending interest rates

- Net capital inflows

- Exchange rate regime classification

- $\mathrm{S} \& \mathrm{P}$ sovereign default data

- Official external (Paris Club) debt restructuring data

- Public debt-to-GDP ratio

- Countries' credit ratings

- Political stability index (civil liberties)

- Total interest payments-to-GDP ratio

- Short-term interest payments-to-GDP ratio

- Haircuts on private external debt restructurings

- Coerciveness index on private external debt restructurings

- Legislative and executive indices of electoral competitiveness (LIEC and EIEC)
Authors' calculation based on WDI (World Bank, 2016a)

WDI (World Bank, 2016a)

IMF International Financial Statistics

IMF World Economic Outlook

Ilzetzki, Reinhart and Rogoff (2015)

Standard and Poor's

Das et al. (2012) and Paris Club

World Bank's Global Financial Development Database

the Institutional Investor magazine

FreedomHouse

World Bank's Global Financial

Development Database

World Bank's Global Financial

Development Database

Cruces and Trebesch (2013)

Enderlein et al. (2012)

Inter-American Development Bank's

Database of Political Institutions 2015 (DIP2015)

Notes: PWT and WDI stand for the Penn World Table and the World Development Indicators, respectively. 


\section{A.3. Data Statistics}

Table A1 presents summary statistics of variables.

Table A1: Summary Statistics

Panel A: Baseline Variables

\begin{tabular}{rrrrrr}
\hline & \multicolumn{1}{c}{ Obs } & \multicolumn{1}{c}{ Mean } & Std. Dev. & \multicolumn{1}{c}{ Min } & \multicolumn{1}{c}{ Max } \\
\hline GDP (billion USD, contant 2010 prices) & 2,501 & 98.47 & 251.01 & 0.16 & 2400 \\
Investment-to-GDP ratio (percent) & 2,205 & 22.17 & 8.39 & -5.74 & 73.49 \\
Private credit-to-GDP ratio (percent) & 2,345 & 27.47 & 18.27 & 1.66 & 105.92 \\
Lending interest rate (percent) & 1,361 & 19.27 & 13.50 & 3.00 & 95.08 \\
Net capital inflows-to-GDP ratio (percent) & 2,069 & 0.08 & 0.15 & -1.15 & 1.24 \\
Cyclical component of log of GDP per capita & 2,159 & 0.00 & 0.07 & -0.65 & 0.52 \\
Public debt-to-GDP ratio (percent) & 1,535 & 73.49 & 47.47 & 1.03 & 316.08 \\
Current account-to-GDP ratio (percent) & 1,986 & -6.62 & 17.60 & -248.13 & 49.16 \\
Foreign reserves-to-GDP ratio (percent) & 1,949 & 0.00 & 0.10 & -0.65 & 2.61 \\
ln(Real exchange rate) & 2,525 & 3.71 & 2.56 & -1.84 & 10.53 \\
GDP growth rate (percent) & 2,437 & 3.66 & 7.08 & -63.38 & 107.41 \\
\hline Panel B: Instruments and Other Variables & & & \\
\hline \# of past post-defaults & 2,816 & 0.87 & 1.09 & 0 & 6 \\
\hline \# of past weakly preemptive & 2,816 & 0.37 & 0.81 & 0 & 4 \\
\# of past strictly preemptive & 2,816 & 0.19 & 0.68 & 0 & 5 \\
\# of past banking crises & 2,816 & 1.56 & 2.36 & 0 & 10 \\
Forecastted GDP growth rate, long-run & 1,472 & 4.71 & 1.98 & -1.82 & 30.03 \\
Forecastted GDP growth rate, short-run & 1,481 & 4.58 & 2.72 & -6.66 & 55.56 \\
\hline EIEC (Political stability index) & 2,296 & 5.28 & 2.13 & 1 & 18.47 \\
Interest payments-to-GDP ratio (percent) & 2,107 & 0.02 & 0.03 & 0 & 0.64 \\
Credit rantings, change & 1,503 & 0.24 & 3.15 & -22.28 & 10.48 \\
Freedom house index, civil liberty & 2,467 & 4.11 & 1.64 & 1 & 7 \\
\# of years from the last debt restructurings & 1,791 & 14.42 & 9.20 & 0 & 38 \\
LIEC (Political stability index) & 2,296 & 5.54 & 2.03 & 1 & 7 \\
\hline
\end{tabular}


Table A2: Debt Restructurings, Private Credit, and Net Capital Inflows, 3-Year Horizon

Panel A: Private Credit, 3-Year Cumulative Percentage Point Difference from Year 0 $d_{i, t+3}^{C}=100 \times\left(\right.$ Credit $_{i, t+3} / G D P_{i, t+3}-$ Credit $\left._{i, t} / G D P_{i, t}\right)$

\begin{tabular}{|c|c|c|c|c|c|c|c|}
\hline & Obs. & Mean & $p(5)$ & $p(25)$ & $p(50)$ & $p(75)$ & $p(95)$ \\
\hline Post-default & 73 & -1.63 & -13.67 & -4.94 & -1.21 & 0.80 & 6.56 \\
\hline Weakly preemptive & 26 & 0.47 & -8.51 & -2.62 & -1.02 & 4.52 & 8.73 \\
\hline Strictly preemptive & 8 & 0.31 & -9.54 & -2.00 & -0.28 & 2.52 & 11.51 \\
\hline All obs. from restructuring countries & 1,895 & 1.56 & -8.13 & -1.22 & 1.53 & 4.65 & 12.17 \\
\hline
\end{tabular}

Panel B: Net Capital Inflows, Sum of Cumulative Percentage Point Differences from Year 0 to Year 3

\begin{tabular}{rrrrrrrr}
\multicolumn{8}{c}{$d_{i, t+3}^{N C I, S U M}=100 \times \sum_{s=1}^{3}\left(N C I_{i, t+s} / G D P_{i, t+s}-N C I_{i, t} / G D P_{i, t}\right)$} \\
\hline Obs. & \multicolumn{1}{c}{ Mean } & $p(5)$ & \multicolumn{1}{c}{$p(25)$} & $p(50)$ & \multicolumn{1}{c}{$p(75)$} & $p(95)$ \\
\hline Post-default & 77 & -10.18 & -77.06 & -31.54 & -4.35 & 9.78 & 41.41 \\
Weakly preemptive & 26 & -4.80 & -53.12 & -16.71 & -0.94 & 11.42 & 29.59 \\
Strictly preemptive & 10 & 11.02 & -31.33 & 1.90 & 6.49 & 17.14 & 91.91 \\
All obs. from restructuring countries & 1,625 & 1.48 & -51.47 & $\mathbf{- 1 3 . 4 0}$ & 0.83 & 15.69 & 53.76 \\
\hline
\end{tabular}

Panel C: Net Capital Inflows, 3-Year Cumulative Percentage Point Differences from Year 0

\begin{tabular}{rrrrrrrr}
\multicolumn{8}{c}{$d_{i, t+3}^{N C I, D I F}=100 \times\left(N C I_{i, t+3} / G D P_{i, t+3}-N C I_{i, t} / G D P_{i, t}\right)$} \\
\hline Obs. & \multicolumn{1}{c}{ Mean } & $p(5)$ & $p(25)$ & $p(50)$ & $p(75)$ & $p(95)$ \\
\hline Post-default & 77 & -2.42 & -31.50 & -8.77 & -1.88 & 3.78 & 16.83 \\
Weakly preemptive & 26 & 0.10 & -23.76 & -8.53 & 1.35 & 6.94 & 26.25 \\
Strictly preemptive & 10 & 6.04 & -13.95 & -0.01 & 5.49 & 8.12 & 38.65 \\
All obs. from restructuring countries & 1,625 & 0.53 & -22.00 & $\mathbf{- 5 . 9 0}$ & 0.48 & 6.81 & 23.33 \\
\hline
\end{tabular}

Notes: The table shows the number of observations (Obs.), mean, 5th percentile $p(5)$, 25th percentile $p(25)$, 50th percentile $p(50)$, 75th percentile $p(75)$, and 95th percentile $p(95)$ of the 3-year cumulative percentage point differences in the credit-to-GDP ratio (Panel A) and in the net capital inflows-to-GDP ratio from year 0 (Panel $C$ ), and the sum of cumulative percentage point differences in the net capital inflows-to-GDP ratio over 3 years from year 0 (Panel B). All observations from restructuring countries reported in the bottom of the tables are from 1970-2007 where the data after the 2008-09 Global Financial Crisis are dropped. 
Table A3: Debt Restructurings, Private Credit, and Net Capital Inflows, 5-Year Horizon

Panel A: Private Credit, 5-Year Cumulative Percentage Point Difference from Year 0 $d_{i, t+5}^{C}=100 \times\left(\right.$ Credit $_{i, t+5} / G D P_{i, t+5}-$ Credit $\left._{i, t} / G D P_{i, t}\right)$

\begin{tabular}{|c|c|c|c|c|c|c|c|}
\hline & Obs. & Mean & $p(5)$ & $p(25)$ & $p(50)$ & $p(75)$ & $p(95)$ \\
\hline Post-default & 73 & -1.72 & -14.79 & -6.63 & -2.35 & 1.99 & 10.15 \\
\hline Weakly preemptive & 26 & 2.75 & -10.04 & -4.15 & 0.23 & 10.86 & 19.82 \\
\hline Strictly preemptive & 9 & 1.11 & -13.72 & -1.48 & 2.00 & 2.63 & 12.92 \\
\hline All obs. from restructuring countries & 1,888 & 2.74 & -9.78 & -1.65 & 2.54 & 7.21 & 17.19 \\
\hline
\end{tabular}

Panel B: Net Capital Inflows, Sum of Cumulative Percentage Point Differences from Year 0 to Year 5 $d_{i, t+5}^{N C I, S U M}=100 \times \sum_{s=1}^{5}\left(N C I_{i, t+s} / G D P_{i, t+s}-N C I_{i, t} / G D P_{i, t}\right)$

\begin{tabular}{rrrrrrrr}
\multicolumn{8}{c}{$d_{i, t+5}^{N C I, S U M}=100 \times \sum_{s=1}^{5}\left(N C I_{i, t+s} / G D P_{i, t+s}-N C I_{i, t} / G D P_{i, t}\right)$} \\
\hline Obs. & \multicolumn{1}{c}{ Mean } & \multicolumn{1}{c}{$p(5)$} & \multicolumn{1}{c}{$p(25)$} & $p(50)$ & $p(75)$ & \multicolumn{1}{c}{$p(95)$} \\
\hline Post-default & 73 & -16.72 & -123.09 & -42.56 & -8.22 & 14.77 & 70.11 \\
Weakly preemptive & 26 & -4.34 & -88.06 & -25.93 & -0.33 & 32.13 & 62.27 \\
Strictly preemptive & 10 & 31.56 & -45.85 & 7.65 & 24.34 & 39.67 & 185.32 \\
All obs. from restructuring countries & 1,599 & 2.34 & -83.49 & $\mathbf{- 2 2 . 4 8}$ & 1.70 & 27.13 & 94.16 \\
\hline
\end{tabular}

Panel C: Net Capital Inflows, 5-Year Cumulative Percentage Point Differences from Year 0 $d_{i, t+5}^{N C I, D I F}=100 \times\left(N C I_{i, t+5} / G D P_{i, t+5}-N C I_{i, t} / G D P_{i, t}\right)$

\begin{tabular}{rrrrrrrr}
\hline & Obs. & \multicolumn{1}{c}{ Mean } & \multicolumn{1}{c}{$p(5)$} & $p(25)$ & $p(50)$ & $p(75)$ & $p(95)$ \\
\hline Post-default & 73 & -3.97 & -31.03 & -12.26 & -3.21 & 5.83 & 19.00 \\
Weakly preemptive & 26 & 0.98 & -22.05 & -7.00 & 0.98 & 9.02 & 18.84 \\
Strictly preemptive & 10 & 11.54 & -5.32 & 2.18 & 8.59 & 18.12 & 44.88 \\
All obs. from restructuring countries & 1,599 & 0.49 & -24.13 & $-\mathbf{7 . 0 5}$ & 0.57 & 7.77 & 25.96 \\
\hline
\end{tabular}

Notes: The table shows the same variables as Table A2 for 5-year horizon. See the notes for Table A2. 


\section{A.4. Severe Credit Declines and Severe Protracted Net Capital Inflow Declines}

Table A4: Dataset, 5-year Horizon

Panel A: Debt Restructuring Sample

\begin{tabular}{rccc}
\hline & Post-default & Weakly preemptive & Strictly preemptive \\
\hline \# of episodes & 111 & 45 & 23 \\
\# of countries & 60 & 26 & 13 \\
Average duration (years) & 5.0 & 1.1 & 0.9 \\
Average haircuts (percent) & 48.0 & 18.2 & 18.9 \\
\hline Representative episodes & Argentina 2001-05, & Ukraine & Pakistan \\
in 1999-2010 & Russia 1998-2000 & (Global Exch.) 2000, & (Ext. bonds) 1999, \\
& & Belize 2006-07 & Uruguay 2003
\end{tabular}

\begin{tabular}{|c|c|c|c|c|c|}
\hline \multicolumn{6}{|c|}{ Panel B: Banking Crisis Sample 2/ } \\
\hline & $\begin{array}{c}\text { All debt } \\
\text { restructurings }\end{array}$ & $\begin{array}{l}\text { Post- } \\
\text { default }\end{array}$ & $\begin{array}{c}\text { Weakly } \\
\text { preemptive }\end{array}$ & Strictly preemptive & $\begin{array}{c}\text { All obs. } \\
1 /\end{array}$ \\
\hline \# of available episodes & 127 & 91 & 39 & 21 & 1,126 \\
\hline \# of banking crises & 39 & 30 & 7 & 2 & 71 \\
\hline Conditional probability & $30.7 \%$ & $33.0 \%$ & $17.9 \%$ & $9.5 \%$ & $6.3 \%$ \\
\hline Representative episodes & & Argentina 2001-05 & Turkey 1981 & Algeria 1990 & \\
\hline in $1999-2010$ & & Russia 1998-2000 & Niger 1983 & Ukraine 1998 & \\
\hline \multicolumn{6}{|c|}{ Panel C: Severe Credit Declines 3/ 6/ } \\
\hline & $\begin{array}{c}\text { All debt } \\
\text { restructurings }\end{array}$ & $\begin{array}{l}\text { Post- } \\
\text { default }\end{array}$ & $\begin{array}{c}\text { Weakly } \\
\text { preemptive }\end{array}$ & Strictly preemptive & $\begin{array}{c}\text { All obs. } \\
1 /\end{array}$ \\
\hline \# of available episodes & 107 & 73 & 26 & 8 & 1,427 \\
\hline \# of severe credit declines & 49 & 39 & 8 & 2 & 314 \\
\hline Conditional probability & $45.8 \%$ & $53.4 \%$ & $30.8 \%$ & $25.0 \%$ & $22.0 \%$ \\
\hline \multirow[t]{2}{*}{ Representative episodes } & & Turkey 1976 & Brazil 1983 & Algeria 1990 & \\
\hline & & Togo 1991 & Venezuela 1986 & Uruguay 2003 & \\
\hline \multicolumn{6}{|c|}{ Panel D: Severe Protracted Net Capital Inflow Declines (Sum) 4/ 6/ } \\
\hline & $\begin{array}{c}\text { All debt } \\
\text { restructurings }\end{array}$ & $\begin{array}{l}\text { Post- } \\
\text { default }\end{array}$ & $\begin{array}{c}\text { Weakly } \\
\text { preemptive }\end{array}$ & Strictly preemptive & $\begin{array}{c}\text { All obs. } \\
1 /\end{array}$ \\
\hline \# of available episodes & 109 & 73 & 26 & 10 & 1,161 \\
\hline \# of severe net cap. inf. dec. & 35 & 25 & 9 & 1 & 303 \\
\hline Conditional probability & $32.1 \%$ & $34.2 \%$ & $34.6 \%$ & $10.0 \%$ & $26.1 \%$ \\
\hline \multirow[t]{2}{*}{ Representative episodes } & & Costa Rica 1981 & Brazil 1982 & Ukraine 1998 & \\
\hline & & Moldova 2001 & Belize 2006 & & \\
\hline \multicolumn{6}{|c|}{ Panel E: Severe Protracted Net Capital Inflow Declines (Difference) 5/ 6/ } \\
\hline & $\begin{array}{c}\text { All debt } \\
\text { restructurings }\end{array}$ & $\begin{array}{l}\text { Post- } \\
\text { default }\end{array}$ & $\begin{array}{c}\text { Weakly } \\
\text { preemptive }\end{array}$ & Strictly preemptive & $\begin{array}{c}\text { All obs. } \\
1 /\end{array}$ \\
\hline \# of available episodes & 109 & 73 & 26 & 10 & 1,161 \\
\hline \# of severe net cap. inf. dec. & 32 & 26 & 6 & 0 & 303 \\
\hline Conditional probability & $29.4 \%$ & $35.6 \%$ & $23.1 \%$ & $0.0 \%$ & $26.1 \%$ \\
\hline
\end{tabular}

Notes: $1 /$ Including episodes in countries without any experience of private external debt restructurings.

2/ Banking crises over five years since the start of debt restructurings, year from $t+1$ to $t+5$.

3 / Severe credit declines are defined as observations with the cumulative percentage point difference in the credit-to-GDP ratio over five years, $d_{i, t+5}^{C}=100 \times\left(\right.$ Credit $_{i, t+5} / G D P_{i, t+5}-$ Credit $\left._{i, t} / G D P_{i, t}\right)$ is less than the 25 th percentile of the distribution.

4/ Severe protracted net capital inflow declines (sum) are defined as observations where the sum of cumulative percentage point differences in the net capital inflows-to-GDP ratio over five years, $d_{t+5}^{N C I, S U M}=100 \times \sum_{s=1}^{5}\left(N C I_{i, t+s} / G D P_{i, t+s}-N C I_{i, t} / G D P_{i, t}\right)$, is less than the 25th percentile of the distribution.

$5 /$ Severe protracted net capital inflow declines (difference) are defined as observations where the cumulative percentage point difference in the net capital inflows-to-GDP ratio over five years, $d_{t+5}^{N C I, D I F}=100 \times\left(N C I_{i, t+5} / G D P_{i, t+5}-N C I_{i, t} / G D P_{i, t}\right)$, is less than the 25 th percentile of the distribution.

6/ The sample after 2008 is dropped because macroeconomic variables in the period are largely influenced by the Global Financial Crisis. Debt restructuring episodes with more than one strategy within a window of $[-2,+3]$ years around the start year of a debt restructuring $t=0$ are coded with the worst strategy only. 
Figure A1: Debt Restructurings, Severe Credit and Net Capital Inflow Declines, 5-year Horizon
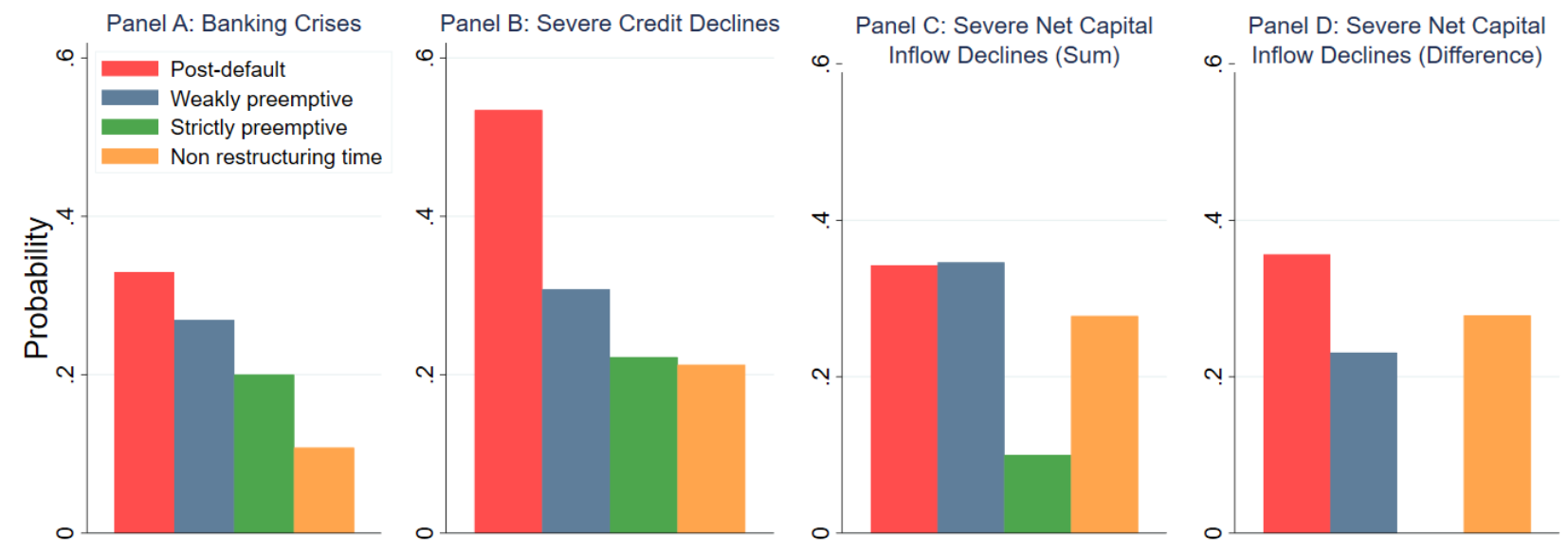

Notes: Panel charts show the probability of banking crises (Panel A), severe credit declines (Panel B), and severe protracted net capital inflow declines (Panels $C$ and $D$ ), respectively.

Panel B: Severe credit declines are defined as observations where the cumulative percentage point difference in the credit-to-GDP ratio over five years, $d_{i, t+5}^{C}=100 \times\left(\right.$ Credit $_{i, t+5} / G D P_{i, t+5}-$ Credit $\left._{i, t} / G D P_{i, t}\right)$, is less than the 25 th percentile of the distribution.

Panel C: Severe protracted net capital inflow declines (sum) are defined as observations where the sum of cumulative percentage point differences in the net capital inflows-to-GDP ratio over five years, $d_{i, t+5}^{N C I, S U M}=100 \times \sum_{s=1}^{5}\left(N C I_{i, t+s} / G D P_{i, t+s}-\right.$ $\left.N C I_{i, t} / G D P_{i, t}\right)$, is less than the 25 th percentile of the distribution.

Panel $\mathrm{D}$ : Severe protracted net capital inflow declines (difference) are defined as observations where the cumulative percentage point difference in the net capital inflows-to-GDP ratio over three years, $d_{t+5}^{N C I, D I F}=100 \times\left(N C I_{i, t+5} / G D P_{i, t+5}-N C I_{i, t} / G D P_{i, t}\right)$, is less than the 25th percentile of the distribution.

The sample after 2008 is dropped because macroeconomic variables in the period are largely influenced by the Global Financial Crisis. Debt restructuring episodes with more than one strategy within a window of $[-2,+3]$ years around the start year of a debt restructuring $t=0$ are coded with the worst strategy only. 


\section{Appendix B. Further Empirical Analysis - Support for Stylized Facts}

We explore whether GDP and investment are tightly associated during debt crisis periods i.e., debt restructuring periods than non-restructuring periods (normal times). For this purpose, we apply an ordinary least square (OLS) estimator on GDP growth rates with contemporaneous investment growth rates in different samples: non-restructuring samples (both all countries and countries that experienced at least one debt restructuring), samples of post-default, weakly preemptive, and strictly preemptive restructurings.

Table B1 shows that both estimated coefficients and explanatory power of investment growth rates (expressed by $R^{2}$ ) are higher in debt restructuring periods (post-default, weakly preemptive and strictly preemptive) than those in non-restructuring periods. Moreover, these are higher than those in the sample of all countries. This clearly shows that GDP growth is tightly linked with investment growth (severely influenced by a decline in investment growth) during debt restructuring periods.

\section{Table B1: Correlation between GDP and Investment Growth Rates}

\begin{tabular}{|c|c|c|c|c|c|c|}
\hline & \multicolumn{2}{|c|}{$\begin{array}{l}\text { Observations without debt } \\
\text { restructurings }\end{array}$} & \multicolumn{4}{|c|}{ Observations with debt restructurings } \\
\hline & $\begin{array}{l}\text { All countries } \\
\text { (1) }\end{array}$ & $\begin{array}{l}\text { Countries that } \\
\text { experienced at } \\
\text { least one debt } \\
\text { restructuring } \\
\text { (2) }\end{array}$ & $\begin{array}{l}\text { During post- } \\
\text { default (the } \\
\text { entire } \\
\text { period) } \\
\text { (3) }\end{array}$ & $\begin{array}{l}\text { During post- } \\
\text { default (the } \\
\text { first half } \\
\text { period) } \\
\text { (4) }\end{array}$ & $\begin{array}{c}\begin{array}{c}\text { During } \\
\text { weakly }\end{array} \\
\text { preemptive } \\
\text { (5) }\end{array}$ & $\begin{array}{c}\text { During } \\
\text { strictly } \\
\text { preemptive } \\
(6)\end{array}$ \\
\hline Investment growth rates $1 /$ & $\begin{array}{c}0.431 * * * \\
(0.074)\end{array}$ & $\begin{array}{c}0.377 * * * \\
(0.137)\end{array}$ & $\begin{array}{l}0.736^{* * * *} \\
(0.094)\end{array}$ & $\begin{array}{l}0.768^{* * * *} \\
(0.076)\end{array}$ & $\begin{array}{c}0.763 * * * \\
(0.176)\end{array}$ & $\begin{array}{l}0.486^{* *} \\
(0.182)\end{array}$ \\
\hline Constant & $\begin{array}{c}3.483 * * * \\
(0.097)\end{array}$ & $\begin{array}{c}3.459 * * * \\
(0.180)\end{array}$ & $\begin{array}{c}1.963 * * * \\
(0.272)\end{array}$ & $\begin{array}{c}1.340 * * * \\
(0.378)\end{array}$ & $\begin{array}{c}2.384 * * * \\
(0.348)\end{array}$ & $\begin{array}{c}2.286^{* * *} \\
(0.624)\end{array}$ \\
\hline Country fixed effects & Yes & Yes & Yes & Yes & Yes & Yes \\
\hline Observations & 4,230 & 1,407 & 297 & 187 & 65 & 18 \\
\hline$R$-squared & 0.264 & 0.189 & 0.324 & 0.353 & 0.41 & 0.321 \\
\hline
\end{tabular}

Notes: Standard errors are in parentheses. ${ }^{* *},{ }^{* *}$, and * indicate the statistical significance at 1 percent, 5 percent, and 10 percent level, respectively.

$1 /$ The explanatory variable is $100 \times\left(\right.$ Investment $_{i, t+1}-$ Investment $\left._{i, t}\right) / G D P_{i, t}$. 


\section{Appendix C. Estimation Results from Local Projections}

\section{C.1. Ordinary Least Square (OLS) Estimator}

Figure C1: Local Projections, OLS
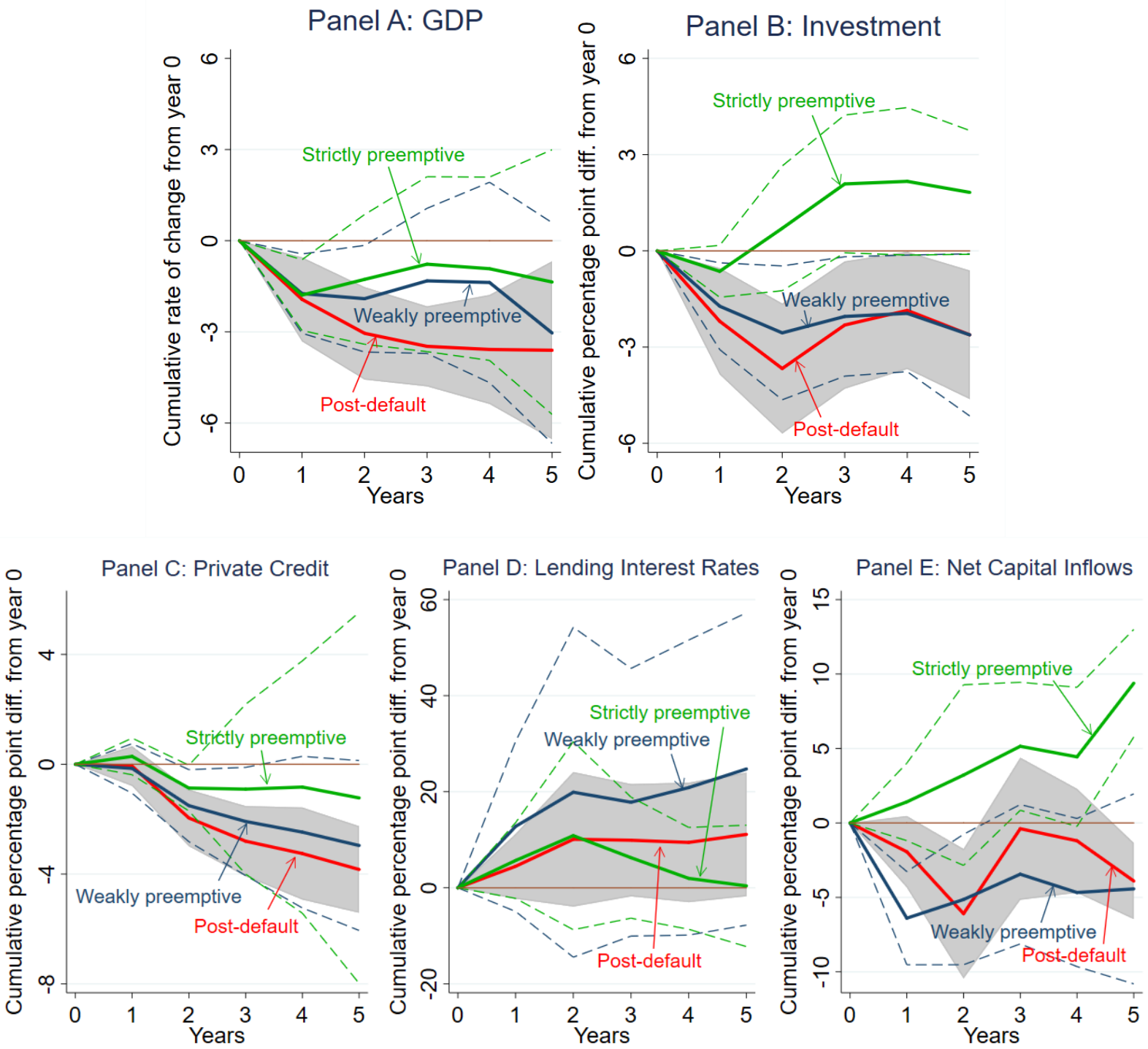

Notes: The figure shows local projections of the variables shown in each panel for $h=1,2, ., 5$, where $h$ indicates horizon. Dependent variables are as follows. Panel A: $100 \times\left(G D P_{i, t+h}-G D P_{i, t}\right) / G D P_{i, t}$, Panel B: $100 \times\left(\right.$ Investment $_{i, t+h} / G D P_{i, t+h}-$ Investment $\left._{i, t} / G D P_{i, t}\right)$, Panel C: $100 \times\left(\right.$ Credit $_{i, t+h} / G D P_{i, t+h}-$ Credit $\left._{i, t} / G D P_{i, t}\right)$, Panel D: $100 \times\left(\right.$ LendingRate $_{i, t+h}-$ LendingRate $\left._{i, t}\right)$, and Panel E: $100 \times\left(N C I_{i, t+h} / G D P_{i, t+h}-N C I_{i, t} / G D P_{i, t}\right)$. Solid lines in red, blue, and green are point estimates. Gray bands and dotted lines in blue and green are 95 percent confidence intervals. The sample period is $1970-2013$. 
Table C1: Estimation Results, OLS

\begin{tabular}{|c|c|c|c|c|c|c|}
\hline & $h=1$ & $h=2$ & $h=3$ & $h=4$ & $h=5$ & Sum \\
\hline Post-default & $-1.930 * * *$ & $-3.047 * * *$ & $-3.477 * * *$ & $-3.579 * * *$ & $-3.605 * *$ & $-15.10^{* * *}$ \\
\hline & $(0.707)$ & $(0.777)$ & $(0.672)$ & $(0.916)$ & $(1.495)$ & $(2.874)$ \\
\hline \multirow[t]{2}{*}{ Weakly preemptive } & $-1.741 * *$ & $-1.909 * *$ & -1.322 & -1.375 & -3.036 & $-9.197 *$ \\
\hline & $(0.665)$ & $(0.895)$ & $(1.218)$ & $(1.683)$ & $(1.853)$ & $(4.914)$ \\
\hline \multirow[t]{2}{*}{ Strictly preemptive } & $-1.790 * * *$ & -1.273 & -0.773 & -0.923 & -1.359 & -5.862 \\
\hline & $(0.594)$ & $(1.089)$ & $(1.469)$ & $(1.539)$ & $(2.221)$ & $(4.002)$ \\
\hline$R$-squared & 0.412 & 0.622 & 0.701 & 0.702 & 0.664 & 0.768 \\
\hline \# of obs. & 2,044 & 2,044 & 1,985 & 1,926 & 1,867 & 1,867 \\
\hline$\#$ of countries & 59 & 59 & 59 & 59 & 59 & 59 \\
\hline \# of post-default obs. & 65 & 65 & 65 & 65 & 65 & 65 \\
\hline \# of weakly preemptive obs. & 31 & 31 & 31 & 31 & 31 & 31 \\
\hline \# of strictly preemptive obs. & 11 & 11 & 11 & 11 & 11 & 11 \\
\hline \multicolumn{7}{|c|}{ Panel B: Dep. Var. $=100 \times\left(\right.$ Investment $_{i, t+h} / G D P_{i, t+h}-$ Investment $\left._{i, t} / G D P_{i, t}\right)$} \\
\hline & $h=1$ & $h=2$ & $h=3$ & $h=4$ & $h=5$ & Sum \\
\hline \multirow[t]{2}{*}{ Post-default } & $-2.196 * *$ & $-3.669 * * *$ & $-2.314 * *$ & $-1.856^{*}$ & $-2.618^{* *}$ & $-12.35 * * *$ \\
\hline & $(0.847)$ & $(1.035)$ & $(1.013)$ & $(0.933)$ & $(1.024)$ & $(4.064)$ \\
\hline \multirow[t]{2}{*}{ Weakly preemptive } & $-1.726^{* *}$ & $-2.557 * *$ & $-2.045 * *$ & $-1.950 * *$ & $-2.620 * *$ & $-11.03 * *$ \\
\hline & $(0.690)$ & $(1.064)$ & $(0.949)$ & $(0.927)$ & $(1.290)$ & $(4.201)$ \\
\hline \multirow[t]{2}{*}{ Strictly preemptive } & -0.639 & 0.702 & $2.086^{*}$ & $2.166^{*}$ & $1.822^{*}$ & 6.055 \\
\hline & $(0.412)$ & $(0.992)$ & $(1.096)$ & $(1.173)$ & $(0.984)$ & $(3.783)$ \\
\hline$R$-squared & 0.054 & 0.138 & 0.179 & 0.191 & 0.199 & 0.235 \\
\hline \# of obs. & 1,757 & 1,757 & 1,702 & 1,647 & 1,592 & 1,592 \\
\hline \# of countries & 55 & 55 & 55 & 55 & 55 & 55 \\
\hline \# of post-default obs. & 56 & 56 & 56 & 56 & 56 & 56 \\
\hline \# of weakly preemptive obs. & 28 & 28 & 28 & 28 & 28 & 28 \\
\hline \# of strictly preemptive obs. & 11 & 11 & 11 & 11 & 11 & 11 \\
\hline \multicolumn{7}{|c|}{ Panel C: Dep. Var. $=100 \times\left(\right.$ Credit $_{i, t+h} / G D P_{i, t+h}-$ Credit $\left._{i, t} / G D P_{i, t}\right)$} \\
\hline & $h=1$ & $h=2$ & $h=3$ & $h=4$ & $h=5$ & Sum \\
\hline \multirow[t]{2}{*}{ Post-default } & -0.066 & $-1.956^{* * *}$ & $-2.800 * * *$ & $-3.252 * * *$ & $-3.832 * * *$ & $-12.06^{* * *}$ \\
\hline & $(0.370)$ & $(0.527)$ & $(0.653)$ & $(0.857)$ & $(0.805)$ & \\
\hline \multirow[t]{2}{*}{ Weakly preemptive } & -0.151 & $-1.506 * *$ & $-2.083 * *$ & $-2.472 *$ & $-2.959 *$ & $-9.340 * *$ \\
\hline & $(0.460)$ & $(0.670)$ & $(1.005)$ & $(1.409)$ & $(1.579)$ & $(4.558)$ \\
\hline \multirow[t]{2}{*}{ Strictly preemptive } & 0.287 & $-0.865 * *$ & -0.906 & -0.829 & -1.225 & -3.327 \\
\hline & $(0.341)$ & $(0.425)$ & $(1.578)$ & $(2.344)$ & $(3.447)$ & $(8.296)$ \\
\hline$R$-squared & 0.073 & 0.049 & 0.038 & 0.029 & 0.026 & 0.046 \\
\hline \# of observations & 1,855 & 1,848 & 1,787 & 1,728 & 1,669 & 1,646 \\
\hline \# of countries & 59 & 59 & 59 & 59 & 58 & 58 \\
\hline \# of post-default obs. & 57 & 56 & 56 & 56 & 56 & 56 \\
\hline \# of weakly preemptive obs. & 31 & 31 & 31 & 31 & 31 & 31 \\
\hline \# of strictly preemptive obs. & 10 & 10 & 9 & 10 & 10 & 9 \\
\hline
\end{tabular}

Notes: The table shows local projections (OLS) of the variables shown in each panel for $h=1,2, \ldots, 5$, where $h$ indicates horizon. All regressions include a constant term, lagged dependent variables (lag 1 and lag 2), cyclical component of log of GDP obtained from a Hodrick-Prescott filter with a smoothing parameter of 100 , and country fixed effects. Robust standard errors, clustered at the countrylevel, are in parentheses. ${ }^{* * *},{ }^{* *}$, and ${ }^{*}$ indicate statistical significance at 1 percent, 5 percent, and 10 percent level, respectively. 
Panel D: Dep. Var. $=100 \times\left(\right.$ LendingRate $_{i, t+h}-$ LendingRate $\left._{i, t}\right)$

\begin{tabular}{rcccccc}
\hline & $h=1$ & $h=2$ & $h=3$ & $h=4$ & $h=5$ & Sum \\
\hline Post-default & 4.47 & 10.09 & 9.91 & 9.45 & $11.12^{*}$ & 44.56 \\
& $(3.45)$ & $(7.15)$ & $(5.97)$ & $(6.35)$ & $(6.57)$ & $(29.61)$ \\
Weakly preemptive & 12.78 & 19.90 & 17.81 & 20.87 & 24.74 & 117.80 \\
& $(9.04)$ & $(17.52)$ & $(14.21)$ & $(15.67)$ & $(16.58)$ & $(87.96)$ \\
Strictly preemptive & 5.68 & 10.86 & 6.27 & 1.97 & 0.40 & 29.90 \\
& $(4.02)$ & $(9.99)$ & $(6.43)$ & $(5.41)$ & $(6.45)$ & $(31.73)$ \\
\hline$R$-squared & 0.12 & 0.226 & 0.498 & 0.519 & 0.524 & 0.419 \\
\# of observations & 1,031 & 1,018 & 965 & 914 & 864 & 847 \\
\# of countries & 52 & 51 & 51 & 51 & 51 & 51 \\
\# of post-default obs. & 24 & 24 & 23 & 23 & 23 & 23 \\
\# of weakly preemptive obs. & 15 & 15 & 15 & 14 & 14 & 14 \\
\# of strictly preemptive obs. & 9 & 9 & 9 & 9 & 9 & 9 \\
\hline
\end{tabular}

Panel E: Dep. Var. $=100 \times\left(N C I_{i, t+h} / G D P_{i, t+h}-N C I_{i, t} / G D P_{i, t}\right)$

\begin{tabular}{rcccccc}
\hline & $h=1$ & $h=2$ & $h=3$ & $h=4$ & $h=5$ & Sum \\
\hline Post-default & -1.934 & $-6.094^{* * *}$ & -0.387 & -1.197 & $-3.898^{* * *}$ & $-13.78^{* * *}$ \\
& $(1.225)$ & $(2.220)$ & $(2.435)$ & $(1.781)$ & $(1.307)$ & $(5.108)$ \\
Weakly preemptive & $-6.394^{* * *}$ & $-5.142^{* *}$ & -3.443 & $-4.671^{*}$ & -4.427 & $-22.87^{* *}$ \\
& $(1.597)$ & $(2.234)$ & $(2.387)$ & $(2.537)$ & $(3.254)$ & $(9.941)$ \\
Strictly preemptive & 1.412 & 3.215 & $5.149 * *$ & $4.438^{*}$ & $9.384^{* * *}$ & $23.07 * * *$ \\
& $(1.326)$ & $(3.094)$ & $(2.194)$ & $(2.382)$ & $(1.842)$ & $(3.756)$ \\
\hline$R$-squared & 0.165 & 0.234 & 0.214 & 0.187 & 0.192 & 0.328 \\
\# of countries & 58 & 58 & 58 & 58 & 58 & 58 \\
\# of countries & 1,662 & 1,651 & 1,588 & 1,527 & 1,466 & 1,454 \\
\# of post-default obs. & 62 & 62 & 62 & 62 & 60 & 60 \\
\# of weakly preemptive obs. & 31 & 31 & 31 & 31 & 31 & 31 \\
\# of strictly preemptive obs. & 10 & 10 & 10 & 10 & 10 & 10 \\
\hline
\end{tabular}

Notes: The table shows local projections (OLS) of the variables shown in each panel for $h=1,2, \ldots, 5$, where $h$ indicates horizon. All regressions include a constant term, lagged dependent variables (lag 1 and lag 2), cyclical component of log of GDP obtained from a Hodrick-Prescott filter with a smoothing parameter of 100 , and country fixed effects. Robust standard errors, clustered at the countrylevel, are in parentheses. ${ }^{* * *},{ }^{* *}$, and ${ }^{*}$ indicate statistical significance at 1 percent, 5 percent, and 10 percent level, respectively. 


\section{C.2. Augmented Inverse Probability Weighted Estimator}

Table C2: Estimation Results, AIPW

\begin{tabular}{|c|c|c|c|c|c|c|}
\hline & $h=1$ & $h=2$ & $h=3$ & $h=4$ & $h=5$ & Sum \\
\hline \multirow[t]{2}{*}{ Post-default } & $-2.486 * * *$ & $-3.141 * * *$ & $-3.777 * * *$ & $-2.422 * * *$ & $-5.178 * * *$ & $-16.21 * * *$ \\
\hline & $(0.314)$ & $(0.461)$ & $(0.479)$ & $(0.607)$ & $(0.966)$ & $(2.237)$ \\
\hline \# of obs. & 825 & 825 & 825 & 825 & 796 & 796 \\
\hline \# of countries & 29 & 29 & 29 & 29 & 29 & 29 \\
\hline \# of debt restructuring obs. & 44 & 44 & 44 & 44 & 44 & 44 \\
\hline \multirow[t]{2}{*}{ Weakly preemptive } & $-2.270 * * *$ & $-2.602 * * *$ & $-1.557 * * *$ & $-2.591 * * *$ & $-4.147 * * *$ & $-12.81 * * *$ \\
\hline & $(0.340)$ & $(0.453)$ & $(0.455)$ & $(0.632)$ & $(0.841)$ & $(2.116)$ \\
\hline \# of obs. & 371 & 371 & 371 & 371 & 357 & 357 \\
\hline \# of countries & 14 & 14 & 14 & 14 & 14 & 14 \\
\hline \# of debt restructuring obs. & 21 & 21 & 21 & 21 & 21 & 21 \\
\hline \multirow[t]{2}{*}{ Strictly preemptive } & $-1.908 * * *$ & $-1.069 * *$ & 1.237 & $2.197^{*}$ & $3.124^{*}$ & 3.921 \\
\hline & $(0.276)$ & $(0.434)$ & $(0.887)$ & $(1.218)$ & $(1.870)$ & $(4.028)$ \\
\hline \# of obs. & 287 & 287 & 280 & 273 & 266 & 266 \\
\hline \# of countries & 7 & 7 & 7 & 7 & 7 & 7 \\
\hline \# of debt restructuring obs. & 11 & 11 & 11 & 11 & 11 & 11 \\
\hline \multicolumn{7}{|c|}{ Panel B: Dep. Var. $=100 \times\left(\right.$ Investment $_{i, t+h} / G D P_{i, t+h}-$ Investment $\left._{i, t} / G D P_{i, t}\right)$} \\
\hline & $h=1$ & $h=2$ & $h=3$ & $h=4$ & $h=5$ & Sum \\
\hline \multirow[t]{2}{*}{ Post-default } & $-1.930 * * *$ & $-2.317 * * *$ & $-0.798 *$ & -0.186 & -0.679 & $-5.714 * *$ \\
\hline & $(0.396)$ & $(0.433)$ & $(0.430)$ & $(0.578)$ & $(0.686)$ & $(2.301)$ \\
\hline \# of obs. & 737 & 737 & 737 & 737 & 711 & 711 \\
\hline \# of countries & 26 & 26 & 26 & 26 & 26 & 26 \\
\hline \# of debt restructuring obs. & 40 & 40 & 40 & 40 & 40 & 40 \\
\hline \multirow[t]{2}{*}{ Weakly preemptive } & -0.211 & -0.386 & 0.180 & -0.664 & $-1.931 * * *$ & -2.726 \\
\hline & $(0.338)$ & $(0.447)$ & $(0.387)$ & $(0.420)$ & $(0.482)$ & $(1.814)$ \\
\hline \# of obs. & 343 & 343 & 343 & 343 & 330 & 330 \\
\hline \# of countries & 13 & 13 & 13 & 13 & 13 & 13 \\
\hline \# of debt restructuring obs. & 20 & 20 & 20 & 20 & 20 & 20 \\
\hline \multirow[t]{2}{*}{ Strictly preemptive } & -0.230 & 0.097 & $1.810 * * *$ & $2.333 * * *$ & $1.425 * * *$ & $5.628 * * *$ \\
\hline & $(0.470)$ & $(0.530)$ & $(0.488)$ & $(0.528)$ & $(0.470)$ & $(1.837)$ \\
\hline \# of obs. & 287 & 287 & 280 & 273 & 266 & 266 \\
\hline \# of countries & 7 & 7 & 7 & 7 & 7 & 7 \\
\hline \# of debt restructuring obs. & 11 & 11 & 11 & 11 & 11 & 11 \\
\hline
\end{tabular}

Notes: The table shows local projections (AIPW) of the variables shown in each panel for $h=1,2, . .5$, where $h$ indicates horizon. All regressions include a constant term, lagged dependent variables (lag 1), cyclical component of log of GDP obtained from a HodrickPrescott filter with a smoothing parameter of 100, and country fixed effects. Robust standard errors, clustered at the country-level, are

in parentheses. ${ }^{* * *},{ }^{* *}$, and ${ }^{*}$ indicate statistical significance at 1 percent, 5 percent, and 10 percent level, respectively. 
Panel C: Dep. Var. $=100 \times\left(\right.$ Credit $_{i, t+h} / G D P_{i, t+h}-$ Credit $\left._{i, t} / G D P_{i, t}\right)$

\begin{tabular}{rcccccc}
\hline & $h=1$ & $h=2$ & $h=3$ & $h=4$ & $h=5$ & Sum \\
\hline Post-default & -0.230 & $-2.038^{* * *}$ & $-2.420^{* * *}$ & $-2.381^{* * *}$ & $-2.563^{* * *}$ & $-9.883^{* * *}$ \\
& $(0.217)$ & $(0.347)$ & $(0.437)$ & $(0.516)$ & $(0.588)$ & $(1.897)$ \\
\# of obs. & 752 & 750 & 748 & 747 & 720 & 716 \\
\# of countries & 27 & 27 & 27 & 27 & 27 & 27 \\
\# of debt restructuring obs. & 41 & 40 & 40 & 40 & 40 & 40 \\
\hline Weakly preemptive & 0.136 & $-1.157^{* * *}$ & $-1.617^{* * *}$ & $-1.824^{* * *}$ & $-2.418^{* * *}$ & $-7.375^{* * *}$ \\
& $(0.192)$ & $(0.276)$ & $(0.358)$ & $(0.471)$ & $(0.550)$ & $(1.590)$ \\
\# of obs. & 371 & 371 & 371 & 371 & 357 & 357 \\
\# of countries & 14 & 14 & 14 & 14 & 14 & 14 \\
\# of debt restructuring obs. & 21 & 21 & 21 & 21 & 21 & 21 \\
\hline Strictly preemptive & $0.881^{* * *}$ & 0.433 & 0.275 & -0.452 & $-1.733^{* *}$ & 0.715 \\
& $(0.331)$ & $(0.505)$ & $(0.508)$ & $(0.611)$ & $(0.736)$ & $(2.131)$ \\
\# of obs. & 284 & 284 & 277 & 270 & 263 & 259 \\
\# of countries & 7 & 7 & 7 & 7 & 7 & 7 \\
\# of debt restructuring obs. & 10 & 10 & 9 & 10 & 10 & 9 \\
\hline
\end{tabular}

\begin{tabular}{|c|c|c|c|c|c|c|}
\hline \multicolumn{7}{|c|}{ Panel D: Dep. Var. $=100$} \\
\hline Post-default & $\begin{array}{c}2.633 * * * \\
(0.410)\end{array}$ & $\begin{array}{c}7.469 * * * \\
(0.692)\end{array}$ & $\begin{array}{c}9.323^{* * *} \\
(0.893)\end{array}$ & $\begin{array}{c}7.412^{* * *} \\
(0.906)\end{array}$ & $\begin{array}{c}10.59 * * * \\
(1.137)\end{array}$ & $\begin{array}{c}38.20 * * * \\
(3.475)\end{array}$ \\
\hline \# of obs. & 356 & 350 & 345 & 340 & 325 & 320 \\
\hline \# of countries & 15 & 15 & 14 & 14 & 14 & 14 \\
\hline \# of debt restructuring obs. & 22 & 22 & 21 & 21 & 21 & 21 \\
\hline Weakly \& strictly pre. & $\begin{array}{c}1.507 \\
(1.357)\end{array}$ & $\begin{array}{c}0.997 \\
(1.671)\end{array}$ & $\begin{array}{c}5.140^{* * *} \\
(1.914)\end{array}$ & $\begin{array}{c}5.829 * * * \\
(1.985)\end{array}$ & $\begin{array}{l}5.233^{* *} \\
(2.100)\end{array}$ & $\begin{array}{l}19.20^{* *} \\
(9.185)\end{array}$ \\
\hline \# of obs. & 135 & 133 & 132 & 130 & 122 & 121 \\
\hline \# of countries & 7 & 7 & 7 & 7 & 7 & 7 \\
\hline \# of debt restructuring obs. & 2 & 2 & 2 & 2 & 2 & 2 \\
\hline \multicolumn{7}{|c|}{ Panel E: Dep. Var. $=100 \times\left(N C I_{i, t+h} / G D P_{i, t+h}-N C I_{i, t} / G D P_{i, t}\right)$} \\
\hline & $h=1$ & $h=2$ & $h=3$ & $h=4$ & $h=5$ & Sum \\
\hline Post-default & $\begin{array}{l}-1.365 \\
(1.056)\end{array}$ & $\begin{array}{c}-4.904 * * * \\
(1.326)\end{array}$ & $\begin{array}{c}0.034 \\
(1.218)\end{array}$ & $\begin{array}{l}-1.926^{*} \\
(1.024)\end{array}$ & $\begin{array}{c}-2.972 * * * \\
(1.017)\end{array}$ & $\begin{array}{c}-10.93 * * * \\
(4.078)\end{array}$ \\
\hline \# of obs. & 792 & 787 & 783 & 778 & 747 & 744 \\
\hline \# of countries & 29 & 29 & 29 & 29 & 29 & 29 \\
\hline \# of debt restructuring obs. & 44 & 44 & 44 & 44 & 43 & 43 \\
\hline Weakly preemptive & $\begin{array}{c}-3.753 * * * \\
(0.782)\end{array}$ & $\begin{array}{l}-1.112 \\
(0.925)\end{array}$ & $\begin{array}{c}0.627 \\
(0.933)\end{array}$ & $\begin{array}{l}-2.060^{*} \\
(1.069)\end{array}$ & $\begin{array}{l}-2.024^{*} \\
(1.151)\end{array}$ & $\begin{array}{c}-7.759 * * \\
(3.950)\end{array}$ \\
\hline \# of obs. & 360 & 358 & 357 & 357 & 343 & 338 \\
\hline \# of countries & 14 & 14 & 14 & 14 & 14 & 14 \\
\hline \# of debt restructuring obs. & 21 & 21 & 21 & 21 & 21 & 21 \\
\hline Strictly preemptive & $\begin{array}{l}0.5717 \\
(1.152)\end{array}$ & $\begin{array}{c}0.169 \\
(1.297)\end{array}$ & $\begin{array}{c}2.041 \\
(1.594)\end{array}$ & $\begin{array}{c}2.597 * * \\
(1.281)\end{array}$ & $\begin{array}{c}7.287 * * * \\
(1.607)\end{array}$ & $\begin{array}{l}12.71 * * \\
(5.784)\end{array}$ \\
\hline \# of obs. & 251 & 251 & 244 & 237 & 230 & 230 \\
\hline \# of countries & 7 & 7 & 7 & 7 & 7 & 7 \\
\hline \# of debt restructuring obs. & 10 & 10 & 10 & 10 & 10 & 10 \\
\hline
\end{tabular}

Notes: The table shows local projections (AIPW) of the variables shown in each panel for $h=1,2, \ldots, 5$, where $h$ indicates horizon. All regressions include a constant term, lagged dependent variables (lag 1), cyclical component of log of GDP obtained from a HodrickPrescott filter with a smoothing parameter of 100, and country fixed effects. Robust standard errors, clustered at the country-level, are in parentheses. ${ }^{* *},{ }^{* *}$, and ${ }^{*}$ indicate statistical significance at 1 percent, 5 percent, and 10 percent level, respectively. 


\section{Appendix D. Further Regression Results - Support for Main Results \\ D.1. Capital Inflow-Credit Channel}

Figure D1: Restructurings with/without Severe Sudden Stops, OLS

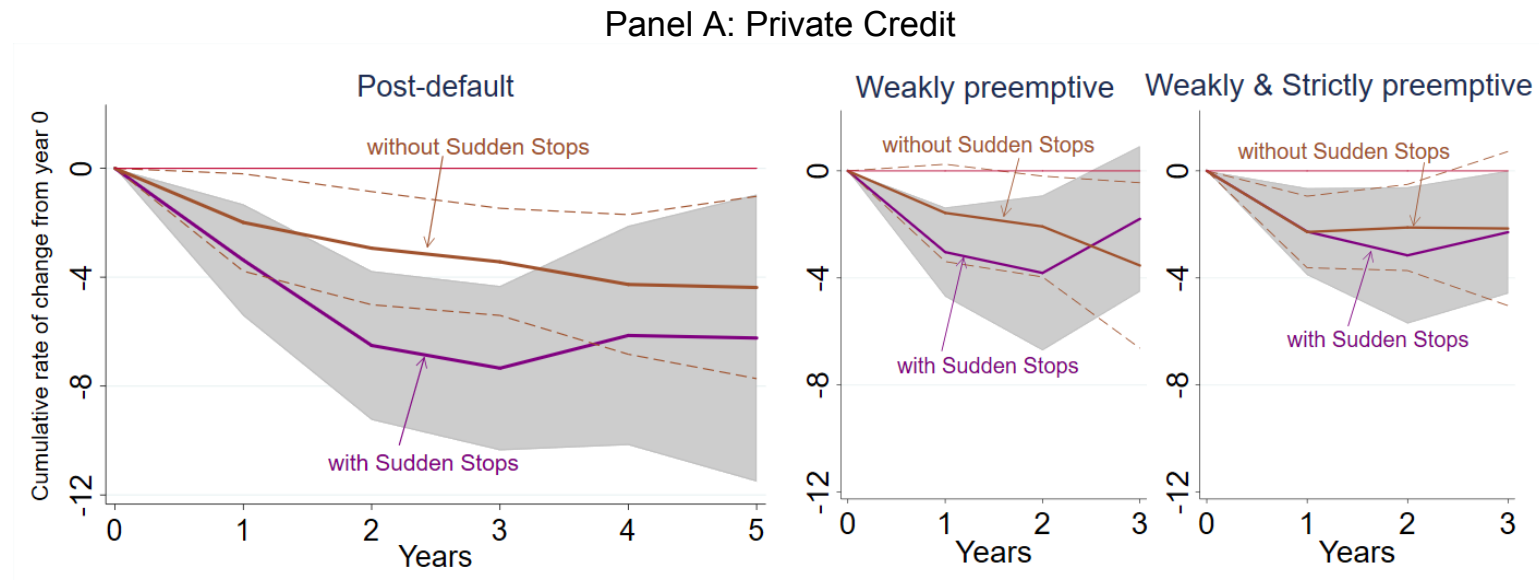

Panel B: Investment
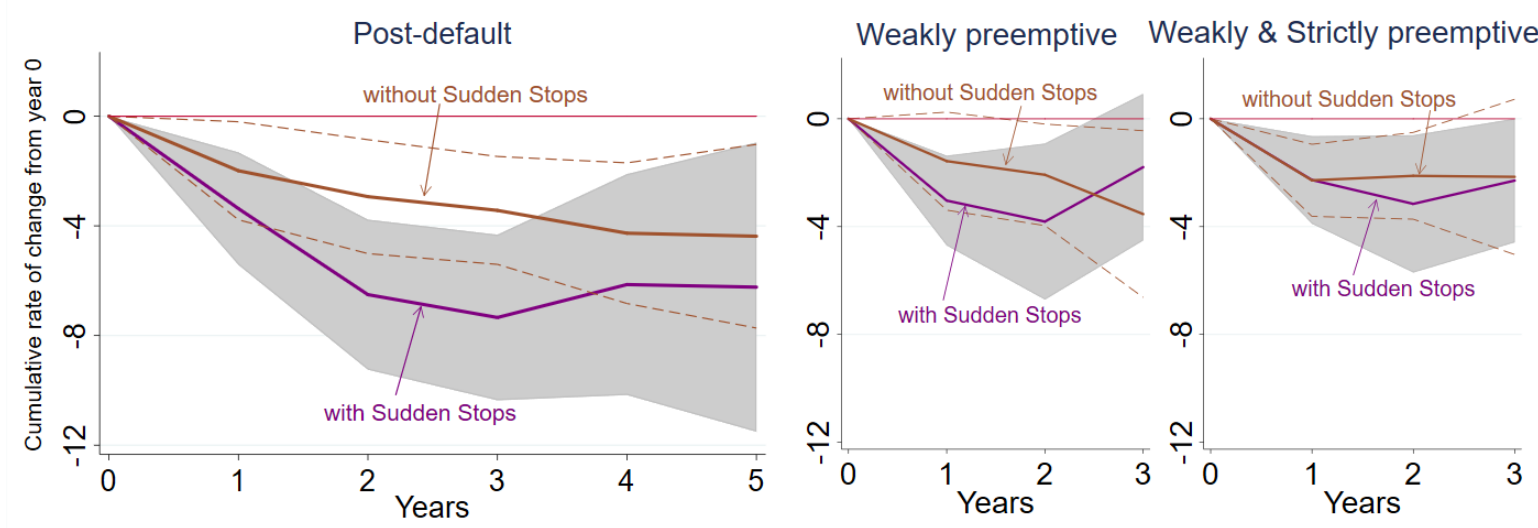

Panel C: GDP
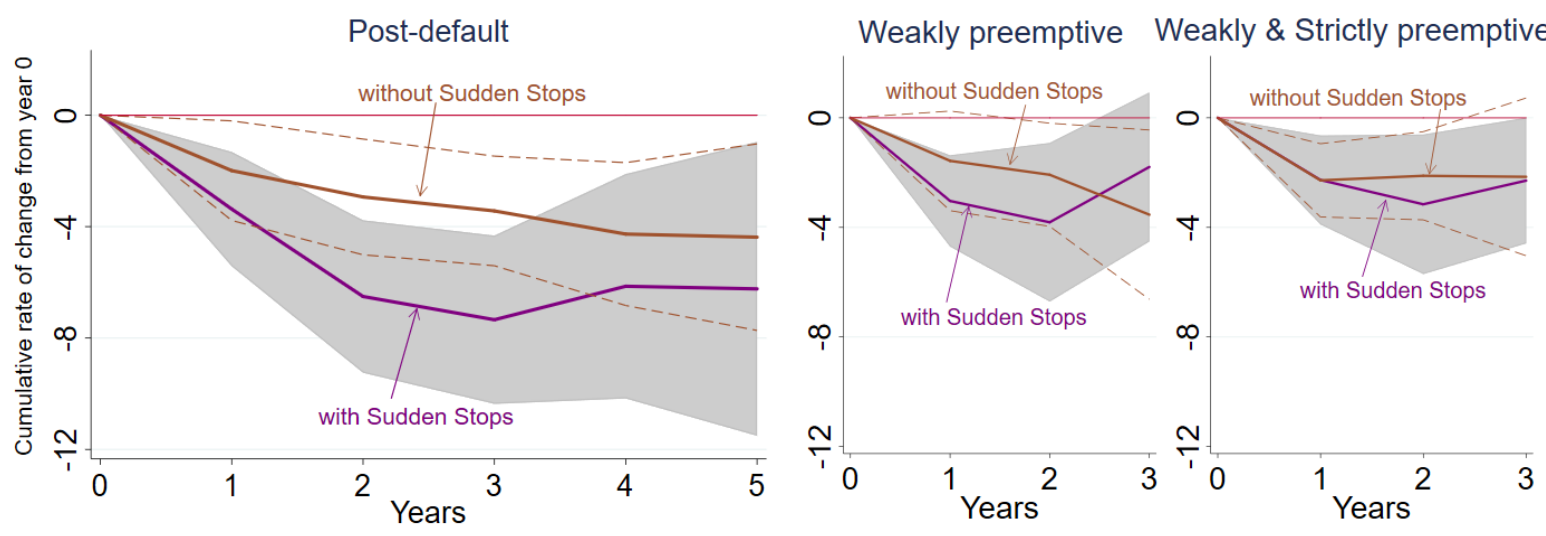

Notes: Severe sudden stops are defined as observations where the percentage point difference in the net capital inflows-to-GDP ratio from year 0 to year $1, \mathrm{~d}_{i, t+1}^{N C I}=100 \times\left(N C I_{i, t+1} / G D P_{i, t+1}-N C I_{i, t} / G D P_{i, t}\right)$, is less than the 25th percentile among the observations experiencing that type of restructurings for Panel $A$. The 50th percentile cutoff for Panels $B$ and $C$ in order to have enough number of observations for both groups. The figure shows AIPW estimates of the variable shown in each panel for $h=1,2, \ldots, 5$, where $h$ indicates horizon. Solid lines in brown and purple are point estimates. Gray bands and dotted lines in brown are 95 percent confidence intervals. The sample period is 1970-2013. 
Table D1: Estimation Results, Restructurings with Severe Sudden Stops, OLS

Panel A: Private Credit

Dep. Var. $=100 \times\left(\right.$ Credit $_{i, t+h}-$ Credit $\left._{i, t}\right) /$ Credit $_{i, t}$

\begin{tabular}{|c|c|c|c|c|c|c|}
\hline & $h=1$ & $h=2$ & $h=3$ & $h=4$ & $h=5$ & Sum \\
\hline Post-default, with sudden stops & -4.027 & $-18.19 * * *$ & $-27.21 * * *$ & $-31.52 * * *$ & $-37.39 * *$ & $-122.7 * * *$ \\
\hline & $(2.477)$ & $(5.333)$ & $(6.966)$ & $(10.05)$ & $(14.87)$ & $(34.32)$ \\
\hline Post-default, without sudden stops & -2.879 & $-14.39 * * *$ & $-20.10 * * *$ & $-21.39 * * *$ & $-26.45 * * *$ & $-85.97 * * *$ \\
\hline & $(3.286)$ & $(4.270)$ & $(5.469)$ & $(7.879)$ & $(8.881)$ & $(28.120)$ \\
\hline Weakly preemptive, with sudden stops & $-8.771 * *$ & $-16.11 * *$ & $-18.13 * *$ & -13.78 & $-23.03 *$ & $-77.32 *$ \\
\hline & $(4.152)$ & $(6.244)$ & $(8.629)$ & $(11.83)$ & $(12.01)$ & $(38.82)$ \\
\hline \multirow[t]{2}{*}{ Weakly preemptive, without sudden stops } & -3.769 & -6.556 & -8.08 & -10.81 & -14.29 & -49.37 \\
\hline & $(2.511)$ & $(5.070)$ & $(7.187)$ & $(10.44)$ & $(15.20)$ & $(35.83)$ \\
\hline$R$-squared & 0.079 & 0.039 & 0.028 & 0.029 & 0.039 & 0.049 \\
\hline \# of observations & 1,904 & 1,898 & 1,836 & 1,775 & 1,716 & 1,692 \\
\hline \# of countries & 59 & 59 & 59 & 59 & 59 & 59 \\
\hline \# of post-default rest. with sudden stops & 14 & 14 & 14 & 14 & 14 & 14 \\
\hline \# of post-default rest. without sudden stops & 43 & 42 & 42 & 42 & 42 & 42 \\
\hline \# of weakly pre. rest. with sudden stops & 8 & 8 & 8 & 8 & 8 & 8 \\
\hline \# of weakly pre. rest. without sudden stops & 23 & 23 & 23 & 23 & 23 & 23 \\
\hline \multirow[t]{2}{*}{ Weakly \& strictly preemptive, with sudden stops } & $-8.285 * *$ & $-16.50 * * *$ & $-19.77 * *$ & $-20.68 *$ & $-34.59 * *$ & $-100.3 * *$ \\
\hline & $(3.302)$ & $(5.293)$ & $(7.835)$ & $(12.35)$ & $(13.54)$ & $(39.78)$ \\
\hline \multirow[t]{2}{*}{ Weakly \& strictly preemptive, without sudden stops } & $-3.563 *$ & $-6.581 *$ & -7.624 & -8.991 & -11.05 & -42.37 \\
\hline & $(1.984)$ & $(3.840)$ & $(5.719)$ & $(8.046)$ & $(11.59)$ & $(28.55)$ \\
\hline$R$-squared & 0.079 & 0.039 & 0.028 & 0.03 & 0.04 & 0.05 \\
\hline \# of observations & 1,904 & 1,898 & 1,836 & 1,775 & 1,716 & 1,692 \\
\hline \# of countries & 59 & 59 & 59 & 59 & 59 & 59 \\
\hline \# of preemptive rest. with sudden stops & 10 & 10 & 10 & 10 & 10 & 10 \\
\hline \# of preemptive rest. without sudden stops & 31 & 31 & 30 & 31 & 31 & 30 \\
\hline
\end{tabular}

Panel B: Investment

Dep. Var. $=100 \times\left(\right.$ Investment $_{i, t+h} / G D P_{i, t+h}-$ Investment $\left._{i, t} / G D P_{i, t}\right)$

\begin{tabular}{|c|c|c|c|c|c|c|}
\hline & $h=1$ & $h=2$ & $h=3$ & $h=4$ & $h=5$ & Sum \\
\hline Post-default, with sudden stops & $\begin{array}{c}-4.376^{* * *} \\
(1.455)\end{array}$ & $\begin{array}{c}-5.180 * * * \\
(1.406)\end{array}$ & $\begin{array}{c}-4.458 * * * \\
(1.066)\end{array}$ & $\begin{array}{c}-1.913 \\
(1.261)\end{array}$ & $\begin{array}{l}-2.327 \\
(1.455)\end{array}$ & $\begin{array}{c}-18.43 * * * \\
(5.403)\end{array}$ \\
\hline Post-default, without sudden stops & $\begin{array}{c}-0.190 \\
(0.899)\end{array}$ & $\begin{array}{l}-1.989 \\
(1.240)\end{array}$ & $\begin{array}{c}-0.489 \\
(1.440)\end{array}$ & $\begin{array}{l}-1.515 \\
(1.130)\end{array}$ & $\begin{array}{l}-2.469 * \\
(1.235)\end{array}$ & $\begin{array}{c}-5.937 \\
(5.170)\end{array}$ \\
\hline Weakly preemptive, with sudden stops & $\begin{array}{c}-3.284 * * * \\
(0.752)\end{array}$ & $\begin{array}{c}-4.714 * * * \\
(1.417)\end{array}$ & $\begin{array}{c}-4.001 * * * \\
(1.038)\end{array}$ & $\begin{array}{c}-3.276 * * * \\
(1.034)\end{array}$ & $\begin{array}{c}-3.721 * * * \\
(1.249)\end{array}$ & $\begin{array}{c}-19.18 * * * \\
(4.253)\end{array}$ \\
\hline Weakly preemptive, without sudden stops & $\begin{array}{c}0.193 \\
(0.822) \\
\end{array}$ & $\begin{array}{l}0.0661 \\
(0.892) \\
\end{array}$ & $\begin{array}{c}0.162 \\
(0.953) \\
\end{array}$ & $\begin{array}{c}-0.346 \\
(1.165) \\
\end{array}$ & $\begin{array}{c}-0.982 \\
(1.910) \\
\end{array}$ & $\begin{array}{c}-0.907 \\
(4.556) \\
\end{array}$ \\
\hline$R$-squared & 0.051 & 0.119 & 0.168 & 0.178 & 0.177 & 0.211 \\
\hline \# of observations & 1,812 & 1,812 & 1,756 & 1,701 & 1,646 & 1,646 \\
\hline \# of countries & 56 & 56 & 55 & 55 & 55 & 55 \\
\hline \# of post-default rest. with sudden stops & 25 & 25 & 25 & 25 & 25 & 25 \\
\hline \# of post-default rest. without sudden stops & 33 & 33 & 33 & 33 & 33 & 33 \\
\hline \# of weakly pre. rest. with sudden stops & 14 & 14 & 14 & 14 & 14 & 14 \\
\hline \# of weakly pre. rest. without sudden stops & 14 & 14 & 14 & 14 & 14 & 14 \\
\hline Weakly \& strictly preemptive, with sudden stops & $\begin{array}{c}-2.897 * * * \\
(0.530)\end{array}$ & $\begin{array}{c}-3.649 * * * \\
(1.355)\end{array}$ & $\begin{array}{c}-2.781 * * \\
(1.135)\end{array}$ & $\begin{array}{c}-2.568 * * * \\
(0.905)\end{array}$ & $\begin{array}{l}-2.435^{*} \\
(1.334)\end{array}$ & $\begin{array}{c}-14.53 * * * \\
(4.389)\end{array}$ \\
\hline Weakly \& strictly preemptive, without sudden stops & $\begin{array}{c}0.0968 \\
(0.578) \\
\end{array}$ & $\begin{array}{c}0.356 \\
(0.740) \\
\end{array}$ & $\begin{array}{c}0.933 \\
(0.846) \\
\end{array}$ & $\begin{array}{c}0.941 \\
(0.995)\end{array}$ & $\begin{array}{l}-0.0167 \\
(1.308) \\
\end{array}$ & $\begin{array}{c}2.335 \\
(3.540) \\
\end{array}$ \\
\hline$R$-squared & 0.051 & 0.118 & 0.167 & 0.178 & 0.176 & 0.210 \\
\hline \# of observations & 1,812 & 1,812 & 1,756 & 1,701 & 1,646 & 1,646 \\
\hline \# of countries & 56 & 56 & 55 & 55 & 55 & 55 \\
\hline \# of preemptive rest. with sudden stops & 18 & 18 & 18 & 18 & 18 & 18 \\
\hline \# of preemptive rest. without sudden stops & 21 & 21 & 21 & 21 & 21 & 21 \\
\hline
\end{tabular}

Notes: The table shows local projections (OLS) of the variables shown in each panel for $h=1,2, \ldots, 5$, where $h$ indicates horizon. All regressions include a constant term, lagged dependent variables (lag 1), cyclical component of log of GDP obtained from a HodrickPrescott filter with a smoothing parameter of 100 , and country fixed effects. Robust standard errors, clustered at the country-level, are in parentheses. ${ }^{* * *},{ }^{* *}$, and ${ }^{*}$ indicate statistical significance at 1 percent, 5 percent, and 10 percent level, respectively. 
Panel C: GDP

\begin{tabular}{|c|c|c|c|c|c|c|}
\hline & $h=1$ & $h=2$ & $h=3$ & $h=4$ & $h=5$ & Sum \\
\hline Post-default, with sudden stops & $\begin{array}{c}-3.496^{* * *} \\
(1.016)\end{array}$ & $\begin{array}{c}-4.940^{* * * *} \\
(1.128)\end{array}$ & $\begin{array}{c}-5.669^{* * *} \\
(1.110)\end{array}$ & $\begin{array}{c}-5.061 * * * \\
(1.594)\end{array}$ & $\begin{array}{c}-5.156^{* *} \\
(2.192)\end{array}$ & $\begin{array}{c}-23.63 * * * \\
(4.670)\end{array}$ \\
\hline Post-default, without sudden stops & $\begin{array}{c}-1.382 \\
(1.066)\end{array}$ & $\begin{array}{c}-2.804 * * \\
(1.344)\end{array}$ & $\begin{array}{c}-3.261^{* *} \\
(1.307)\end{array}$ & $\begin{array}{c}-4.393 * * * \\
(1.575)\end{array}$ & $\begin{array}{c}-4.509^{* *} \\
(2.110)\end{array}$ & $\begin{array}{c}-15.76^{* * *} \\
(5.754)\end{array}$ \\
\hline Weakly preemptive, with sudden stops & $\begin{array}{c}-3.024 * * * \\
(0.850)\end{array}$ & $\begin{array}{c}-3.809 * * \\
(1.479)\end{array}$ & $\begin{array}{l}-1.787 \\
(1.389)\end{array}$ & $\begin{array}{l}-0.337 \\
(1.957)\end{array}$ & $\begin{array}{l}-1.676 \\
(2.180)\end{array}$ & $\begin{array}{l}-10.66 \\
(6.471)\end{array}$ \\
\hline Weakly preemptive, without sudden stops & $\begin{array}{l}-1.572^{*} \\
(0.925) \\
\end{array}$ & $\begin{array}{c}-2.064 * * \\
(0.959) \\
\end{array}$ & $\begin{array}{c}-3.519 * * \\
(1.577) \\
\end{array}$ & $\begin{array}{c}-5.762 * * * \\
(1.843) \\
\end{array}$ & $\begin{array}{c}-7.853 * * * \\
(2.269) \\
\end{array}$ & $\begin{array}{c}-20.54 * * * \\
(5.807) \\
\end{array}$ \\
\hline$R$-squared & 0.324 & 0.497 & 0.597 & 0.620 & 0.601 & 0.662 \\
\hline \# of observations & 2,102 & 2,102 & 2,043 & 1,984 & 1,925 & 1,925 \\
\hline \# of countries & 59 & 59 & 59 & 59 & 59 & 59 \\
\hline \# of post-default rest. with sudden stops & 29 & 29 & 29 & 29 & 29 & 29 \\
\hline \# of post-default rest. without sudden stops & 38 & 38 & 38 & 38 & 38 & 38 \\
\hline \# of weakly pre. rest. with sudden stops & 16 & 16 & 16 & 16 & 16 & 16 \\
\hline \# of weakly pre. rest. without sudden stops & 15 & 15 & 15 & 15 & 15 & 15 \\
\hline Weakly \& strictly preemptive, with sudden stops & $\begin{array}{c}-2.259 * * * \\
(0.829)\end{array}$ & $\begin{array}{c}-3.152^{* *} \\
(1.302)\end{array}$ & $\begin{array}{l}-2.286^{*} \\
(1.172)\end{array}$ & $\begin{array}{l}-0.996 \\
(1.658)\end{array}$ & $\begin{array}{l}-1.523 \\
(1.823)\end{array}$ & $\begin{array}{c}-10.31 * \\
(5.245)\end{array}$ \\
\hline Weakly \& strictly preemptive, without sudden stops & $\begin{array}{c}-2.286^{* * *} \\
(0.681) \\
\end{array}$ & $\begin{array}{c}-2.109^{* *} \\
(0.818) \\
\end{array}$ & $\begin{array}{c}-2.148 \\
(1.466) \\
\end{array}$ & $\begin{array}{c}-4.052^{* *} \\
(1.778) \\
\end{array}$ & $\begin{array}{c}-6.187 * * * \\
(2.295) \\
\end{array}$ & $\begin{array}{c}-16.44 * * * \\
(5.565) \\
\end{array}$ \\
\hline$R$-squared & 0.324 & 0.497 & 0.597 & 0.62 & 0.601 & 0.662 \\
\hline \# of observations & 2,102 & 2,102 & 2,043 & 1,984 & 1,925 & 1,925 \\
\hline \# of countries & 59 & 59 & 59 & 59 & 59 & 59 \\
\hline \# of preemptive rest. with sudden stops & 21 & 21 & 21 & 21 & 21 & 21 \\
\hline \# of preemptive rest. without sudden stops & 21 & 21 & 21 & 21 & 21 & 21 \\
\hline
\end{tabular}

Notes: The table shows local projections (OLS) of the variables shown in each panel for $h=1,2, \ldots, 5$, where $h$ indicates horizon. All regressions include a constant term, lagged dependent variables (lag 1), cyclical component of log of GDP obtained from a HodrickPrescott filter with a smoothing parameter of 100 , and country fixed effects. Robust standard errors, clustered at the country-level, are in parentheses. ${ }^{* *},{ }^{* *}$, and ${ }^{*}$ indicate statistical significance at 1 percent, 5 percent, and 10 percent level, respectively. 
Table D2: Estimation Results, Restructurings with Severe Sudden Stops, AIPW, Two-type Model

Panel A: Private Credit

\begin{tabular}{|c|c|c|c|c|c|c|}
\hline & $h=1$ & $h=2$ & $h=3$ & $h=4$ & $h=5$ & Sum \\
\hline Post-default, with sudden stops & $\begin{array}{c}-4.012^{* * *} \\
(0.721)\end{array}$ & $\begin{array}{c}-22.70^{* * *} \\
(1.172)\end{array}$ & $\begin{array}{c}-29.11^{* * *} \\
(1.506)\end{array}$ & $\begin{array}{c}-32.33^{* * *} \\
(1.812)\end{array}$ & $\begin{array}{c}-37.57^{* * * *} \\
(2.257)\end{array}$ & $\begin{array}{c}-127.8^{* * *} \\
(6.919)\end{array}$ \\
\hline \# of obs. & 752 & 750 & 748 & 747 & 720 & 716 \\
\hline \# of countries & 27 & 27 & 27 & 27 & 27 & 27 \\
\hline \# of debt restructuring obs. & 10 & 10 & 10 & 10 & 10 & 10 \\
\hline Post-default, without sudden stops & $\begin{array}{c}-3.403 * * * \\
(0.863)\end{array}$ & $\begin{array}{c}-11.27^{* * *} \\
(1.460)\end{array}$ & $\begin{array}{c}-12.70^{* * *} \\
(2.041)\end{array}$ & $\begin{array}{c}-6.577 * * \\
(3.192)\end{array}$ & $\begin{array}{c}-8.876^{* *} \\
(4.292)\end{array}$ & $\begin{array}{c}-42.83^{* * *} \\
(10.847)\end{array}$ \\
\hline \# of obs. & 752 & 750 & 748 & 747 & 720 & 716 \\
\hline \# of countries & 27 & 27 & 27 & 27 & 27 & 27 \\
\hline \# of debt restructuring obs. & 31 & 30 & 30 & 30 & 30 & 30 \\
\hline Weakly preemptive, with sudden stops & $\begin{array}{c}0.081 \\
(0.840)\end{array}$ & $\begin{array}{c}-4.583 * * * \\
(1.514)\end{array}$ & $\begin{array}{c}-7.017 * * * \\
(2.025)\end{array}$ & $\begin{array}{c}0.361 \\
(2.504)\end{array}$ & $\begin{array}{c}-7.893 * * * \\
(2.938)\end{array}$ & $\begin{array}{c}-23.48 * * * \\
(8.938)\end{array}$ \\
\hline \# of obs. & 371 & 371 & 371 & 371 & 357 & 357 \\
\hline \# of countries & 14 & 14 & 14 & 14 & 14 & 14 \\
\hline \# of debt restructuring obs. & 5 & 5 & 5 & 5 & 5 & 5 \\
\hline Weakly preemptive, without sudden stops & $\begin{array}{c}-3.918^{* * *} \\
(0.946)\end{array}$ & $\begin{array}{c}-4.471^{* * *} \\
(1.608)\end{array}$ & $\begin{array}{l}-1.784 \\
(2.230)\end{array}$ & $\begin{array}{c}0.263 \\
(2.940)\end{array}$ & $\begin{array}{l}-1.038 \\
(3.855)\end{array}$ & $\begin{array}{c}-13.62 \\
(10.516)\end{array}$ \\
\hline \# of obs. & 371 & 371 & 371 & 371 & 357 & 357 \\
\hline \# of countries & 14 & 14 & 14 & 14 & 14 & 14 \\
\hline \# of debt restructuring obs. & 16 & 16 & 16 & 16 & 16 & 16 \\
\hline Weakly \& strictly pre., with sudden stops & $\begin{array}{c}-8.986^{* * *} \\
(0.640)\end{array}$ & $\begin{array}{c}-14.06^{* * *} \\
(1.044)\end{array}$ & $\begin{array}{c}-12.96^{* * *} \\
(1.516)\end{array}$ & $\begin{array}{c}-8.786^{* * *} \\
(2.145)\end{array}$ & $\begin{array}{c}-17.66^{* * *} \\
(2.522)\end{array}$ & $\begin{array}{c}-63.46^{* * *} \\
(7.332)\end{array}$ \\
\hline \# of obs. & 894 & 893 & 870 & 847 & 825 & 818 \\
\hline \# of countries & 23 & 23 & 23 & 23 & 23 & 23 \\
\hline \# of debt restructuring obs. & 10 & 10 & 10 & 10 & 10 & 10 \\
\hline Weakly \& strictly pre., without sudden stops & $\begin{array}{c}-5.330^{* * *} \\
(0.960)\end{array}$ & $\begin{array}{c}-7.823^{* * *} \\
(1.353)\end{array}$ & $\begin{array}{c}-9.510^{* * *} \\
(1.980)\end{array}$ & $\begin{array}{c}-13.811^{* * *} \\
(2.638)\end{array}$ & $\begin{array}{c}-22.09 * * * \\
(3.385)\end{array}$ & $\begin{array}{c}-60.38^{* * *} \\
(9.577)\end{array}$ \\
\hline \# of obs. & 894 & 893 & 870 & 847 & 825 & 818 \\
\hline & 23 & 23 & 23 & 23 & 23 & 23 \\
\hline \# of debt restructuring obs. & 31 & 31 & 30 & 31 & 31 & 30 \\
\hline
\end{tabular}

Notes: All regressions include a constant term, the lagged dependent variable, cyclical component of log of GDP obtained from a Hodrick-Prescott filter with a smoothing parameter of 100 , and country fixed effects. 
Panel B: Investment

\begin{tabular}{|c|c|c|c|c|c|c|}
\hline & $h=1$ & $h=2$ & $h=3$ & $h=4$ & $h=5$ & Sum \\
\hline \multirow[t]{2}{*}{ Post-default, with sudden stops } & $-4.072 * * *$ & $-3.607 * * *$ & $-2.156^{* * *}$ & -0.434 & -0.401 & $-10.70 * * *$ \\
\hline & $(0.321)$ & $(0.380)$ & $(0.369)$ & $(0.531)$ & $(0.622)$ & $(2.076)$ \\
\hline \# of obs. & 737 & 737 & 737 & 737 & 711 & 711 \\
\hline \# of countries & 26 & 26 & 26 & 26 & 26 & 26 \\
\hline \# of debt restructuring obs. & 16 & 16 & 16 & 16 & 16 & 16 \\
\hline \multirow[t]{2}{*}{ Post-default, without sudden stops } & 0.060 & $-1.354 * * *$ & 0.338 & -0.037 & $-0.932 * *$ & -1.565 \\
\hline & $(0.235)$ & $(0.315)$ & $(0.309)$ & $(0.363)$ & $(0.429)$ & $(1.453)$ \\
\hline \# of obs. & 737 & 737 & 737 & 737 & 711 & 711 \\
\hline \# of countries & 26 & 26 & 26 & 26 & 26 & 26 \\
\hline \# of debt restructuring obs. & 24 & 24 & 24 & 24 & 24 & 24 \\
\hline \multirow[t]{2}{*}{ Weakly preemptive, with sudden stops } & $-3.059 * * *$ & $-4.517 * * *$ & $-2.861 * * *$ & $-3.504 * * *$ & $-4.084 * * *$ & $-18.04 * * *$ \\
\hline & $(0.197)$ & $(0.267)$ & $(0.311)$ & $(0.312)$ & $(0.341)$ & $(1.170)$ \\
\hline \# of obs. & 343 & 343 & 343 & 343 & 330 & 330 \\
\hline \# of countries & 13 & 13 & 13 & 13 & 13 & 13 \\
\hline \# of debt restructuring obs. & 8 & 8 & 8 & 8 & 8 & 8 \\
\hline \multirow[t]{2}{*}{ Weakly preemptive, without sudden stops } & $1.596^{* * *}$ & $2.342 * * *$ & $2.134 * * *$ & $1.216^{* * *}$ & -0.427 & $7.278 * * *$ \\
\hline & $(0.277)$ & $(0.353)$ & $(0.311)$ & $(0.368)$ & $(0.446)$ & $(1.475)$ \\
\hline \# of obs. & 343 & 343 & 343 & 343 & 330 & 330 \\
\hline \# of countries & 13 & 13 & 13 & 13 & 13 & 13 \\
\hline \# of debt restructuring obs. & 12 & 12 & 12 & 12 & 12 & 12 \\
\hline \multirow[t]{2}{*}{ Weakly \& strictly pre., with sudden stops } & $-3.121 * * *$ & $-4.967 * * *$ & $-3.006^{* * *}$ & $-3.281 * * *$ & $-4.015^{* * *}$ & $-18.44 * * *$ \\
\hline & $(0.205)$ & $(0.385)$ & $(0.292)$ & $(0.298)$ & $(0.317)$ & $(1.281)$ \\
\hline \# of obs. & 791 & 791 & 771 & 751 & 731 & 731 \\
\hline \# of countries & 20 & 20 & 20 & 20 & 20 & 20 \\
\hline \# of debt restructuring obs. & 18 & 18 & 18 & 18 & 18 & 18 \\
\hline \multirow[t]{2}{*}{ Weakly \& strictly pre., without sudden stops } & 0.422 & $1.238 * * *$ & $1.863 * * *$ & $1.501 * * *$ & 0.292 & $5.391 * * *$ \\
\hline & $(0.259)$ & $(0.343)$ & $(0.372)$ & $(0.415)$ & $(0.412)$ & $(1.472)$ \\
\hline \# of obs. & 791 & 791 & 771 & 751 & 731 & 731 \\
\hline \# of countries & 20 & 20 & 20 & 20 & 20 & 20 \\
\hline \# of debt restructuring obs. & 21 & 21 & 21 & 21 & 21 & 21 \\
\hline
\end{tabular}

Notes: All regressions include a constant term, the lagged dependent variable, cyclical component of log of GDP obtained from a Hodrick-Prescott filter with a smoothing parameter of 100 , and country fixed effects. 
Panel C: GDP

\begin{tabular}{|c|c|c|c|c|c|c|}
\hline & $h=1$ & $h=2$ & $h=3$ & $h=4$ & $h=5$ & Sum \\
\hline \multirow[t]{2}{*}{ Post-default, with sudden stops } & $-4.049 * * *$ & $-4.839 * * *$ & $-5.462 * * *$ & $-4.845 * * *$ & $-6.507 * * *$ & $-24.89 * * *$ \\
\hline & $(0.243)$ & $(0.303)$ & $(0.332)$ & $(0.446)$ & $(0.472)$ & $(1.421)$ \\
\hline \# of obs. & 825 & 825 & 825 & 825 & 796 & 796 \\
\hline \# of countries & 29 & 29 & 29 & 29 & 29 & 29 \\
\hline \# of debt restructuring obs. & 17 & 17 & 17 & 17 & 17 & 17 \\
\hline \multirow[t]{2}{*}{ Post-default, without sudden stops } & $-1.371 * * *$ & $-2.412 * * *$ & $-2.718 * * *$ & -0.710 & $-3.727 * * *$ & $-10.17 * * *$ \\
\hline & $(0.231)$ & $(0.388)$ & $(0.422)$ & $(0.482)$ & $(0.810)$ & $(1.884)$ \\
\hline \# of obs. & 825 & 825 & 825 & 825 & 796 & 796 \\
\hline \# of countries & 29 & 29 & 29 & 29 & 29 & 29 \\
\hline \# of debt restructuring obs. & 27 & 27 & 27 & 27 & 27 & 27 \\
\hline \multirow[t]{2}{*}{ Weakly preemptive, with sudden stops } & $-3.149 * * *$ & $-3.583 * * *$ & $-2.259 * * *$ & -0.188 & $1.174 *$ & $-7.849 * * *$ \\
\hline & $(0.304)$ & $(0.406)$ & $(0.419)$ & $(0.580)$ & $(0.665)$ & $(1.893)$ \\
\hline \# of obs. & 371 & 371 & 371 & 371 & 357 & 357 \\
\hline \# of countries & 14 & 14 & 14 & 14 & 14 & 14 \\
\hline \# of debt restructuring obs. & 9 & 9 & 9 & 9 & 9 & 9 \\
\hline \multirow[t]{2}{*}{ Weakly preemptive, without sudden stops } & $-1.667 * * *$ & $-1.802 * * *$ & $-1.152 * * *$ & $-4.718 * * *$ & $-7.958 * * *$ & $-16.67 * * *$ \\
\hline & $(0.278)$ & $(0.361)$ & $(0.433)$ & $(0.518)$ & $(0.647)$ & $(1.720)$ \\
\hline \# of obs. & 371 & 371 & 371 & 371 & 357 & 357 \\
\hline \# of countries & 14 & 14 & 14 & 14 & 14 & 14 \\
\hline \# of debt restructuring obs. & 12 & 12 & 12 & 12 & 12 & 12 \\
\hline \multirow[t]{2}{*}{ Weakly \& strictly pre., with sudden stops } & $-2.347 * * *$ & $-3.810 * * *$ & $-3.299 * * *$ & $-1.730 * * *$ & $-2.974 * * *$ & $-14.25 * * *$ \\
\hline & $(0.222)$ & $(0.420)$ & $(0.337)$ & $(0.393)$ & $(0.475)$ & $(1.409)$ \\
\hline \# of obs. & 910 & 910 & 887 & 864 & 841 & 841 \\
\hline \# of countries & 23 & 23 & 23 & 23 & 23 & 23 \\
\hline \# of debt restructuring obs. & 21 & 21 & 21 & 21 & 21 & 21 \\
\hline \multirow[t]{2}{*}{ Weakly \& strictly pre., without sudden stops } & $-2.816^{* * *}$ & $-1.672 * * *$ & -0.177 & $-2.269 * * *$ & $-5.212 * * *$ & $-11.78 * * *$ \\
\hline & $(0.251)$ & $(0.296)$ & $(0.450)$ & $(0.653)$ & $(0.893)$ & $(2.116)$ \\
\hline \# of obs. & 910 & 910 & 887 & 864 & 841 & 841 \\
\hline \# of countries & 23 & 23 & 23 & 23 & 23 & 23 \\
\hline \# of debt restructuring obs. & 21 & 21 & 21 & 21 & 21 & 21 \\
\hline
\end{tabular}

Notes: All regressions include a constant term, the lagged dependent variable, cyclical component of log of GDP obtained from a Hodrick-Prescott filter with a smoothing parameter of 100 , and country fixed effects.

Figure D2: Post-Default Debt Restructurings with/without Severe Sudden Stops, AIPW, One-type Model
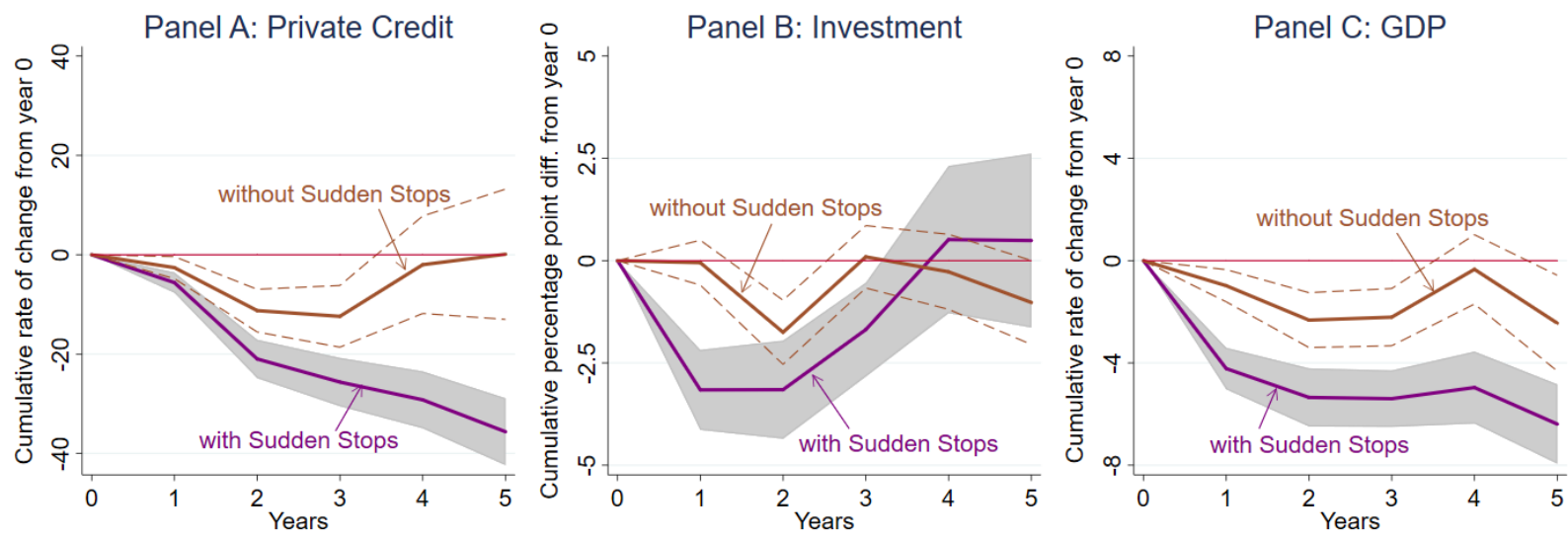

Notes: Severe sudden stops are defined as observations where the percentage point difference in the net capital inflows-to-GDP ratio from year 0 to year $1, \mathrm{~d}_{i, t+1}^{N C I}=100 \times\left(N C I_{i, t+1} / G D P_{i, t+1}-N C I_{i, t} / G D P_{i, t}\right)$, is less than the 25th percentile among the observations experiencing that type of restructurings. The figure shows AIPW estimates of the variable shown in each panel for $h=1,2, \ldots, 5$, where $h$ indicates horizon. Solid lines in brown and purple are point estimates. Gray bands and dotted lines in brown are 95 percent confidence intervals. The sample period is 1970-2013. 
Table D3: Estimation Results, Restructurings with Severe Sudden Stops, AIPW, One-type Model

Panel A: Private Credit

Dep. Var. $=100 \times\left(\right.$ Credit $_{i, t+h}-$ Credit $\left._{i, t}\right) /$ Credit $_{i, t}$

\begin{tabular}{|c|c|c|c|c|c|c|}
\hline & $h=1$ & $h=2$ & $h=3$ & $h=4$ & $h=5$ & Sum \\
\hline \multirow[t]{2}{*}{ Post-default, with sudden stops } & $-5.608 * * *$ & $-20.98 * * *$ & $-25.64 * * *$ & $-29.22 * * *$ & $-35.63 * * *$ & $-118.02 * * *$ \\
\hline & $(1.048)$ & $(1.976)$ & $(2.489)$ & $(2.930)$ & $(3.443)$ & $(10.805)$ \\
\hline \# of obs. & 385 & 385 & 385 & 385 & 372 & 372 \\
\hline \# of countries & 14 & 14 & 14 & 14 & 14 & 14 \\
\hline \# of debt restructuring obs. & 16 & 16 & 16 & 16 & 16 & 16 \\
\hline \multirow[t]{2}{*}{ Post-default, without sudden stops } & $-2.593 * * *$ & $-11.25^{* * *}$ & $-12.41 * * *$ & -2.012 & 0.107 & $-28.24^{*}$ \\
\hline & $(1.133)$ & $(2.193)$ & $(3.169)$ & $(5.003)$ & $(6.687)$ & $(17.116)$ \\
\hline \# of obs. & 505 & 503 & 501 & 500 & 482 & 478 \\
\hline \# of countries & 18 & 18 & 18 & 18 & 18 & 18 \\
\hline \# of debt restructuring obs. & 25 & 24 & 24 & 24 & 24 & 24 \\
\hline
\end{tabular}

Panel B: Investment

Dep. Var. $=100 \times\left(\right.$ Investment $_{i, t+h} / G D P_{i, t+h}-$ Investment $\left._{i, t} / G D P_{i, t}\right)$

\begin{tabular}{rcccccc}
\hline & $h=1$ & $h=2$ & $h=3$ & $h=4$ & $h=5$ & Sum \\
\hline Post-default, with sudden stops & $-3.159^{* * *}$ & $-3.153^{* * *}$ & $-1.685^{* * *}$ & 0.516 & 0.492 & $-6.927^{* *}$ \\
& $(0.499)$ & $(0.613)$ & $(0.585)$ & $(0.918)$ & $(1.085)$ & $(3.477)$ \\
\# of obs. & 386 & 386 & 386 & 386 & 373 & 373 \\
\# of countries & 14 & 14 & 14 & 14 & 14 & 14 \\
\# of debt restructuring obs. & 16 & 16 & 16 & 16 & 16 & 16 \\
\hline Post-default, without sudden stops & -0.049 & $-1.751^{* * *}$ & 0.094 & -0.273 & $-1.022^{*}$ & -2.633 \\
& $(0.280)$ & $(0.400)$ & $(0.389)$ & $(0.468)$ & $(0.523)$ & $(1.751)$ \\
\# of obs. & 488 & 488 & 488 & 488 & 471 & 471 \\
\# of countries & 17 & 17 & 17 & 17 & 17 & 17 \\
\# of debt restructuring obs. & 24 & 24 & 24 & 24 & 24 & 24 \\
\hline
\end{tabular}

Panel C: GDP

\begin{tabular}{|c|c|c|c|c|c|c|}
\hline & $h=1$ & $h=2$ & $h=3$ & $h=4$ & $h=5$ & Sum \\
\hline \multirow[t]{2}{*}{ Post-default, with sudden stops } & $-4.219 * * *$ & $-5.348 * * *$ & $-5.398 * * *$ & $-4.962 * * *$ & $-6.389 * * *$ & $-25.43 * * *$ \\
\hline & $(0.416)$ & $(0.580)$ & $(0.563)$ & $(0.719)$ & $(0.793)$ & $(2.264)$ \\
\hline \multirow{2}{*}{$\begin{array}{r}\text { \# of obs. } \\
\text { \# of countries }\end{array}$} & 416 & 416 & 416 & 416 & 402 & 402 \\
\hline & 15 & 15 & 15 & 15 & 15 & 15 \\
\hline \multirow{3}{*}{$\frac{\text { \# of debt restructuring obs. }}{\text { Post-default, without sudden stops }}$} & 17 & 17 & 17 & 17 & 17 & 17 \\
\hline & $-0.980 * * *$ & $-2.325 * * *$ & $-2.209 * * *$ & -0.340 & $-2.443 * * *$ & $-7.514 * * *$ \\
\hline & $(0.321)$ & $(0.548)$ & $(0.571)$ & $(0.691)$ & $(0.954)$ & $(2.545)$ \\
\hline \multirow{2}{*}{$\begin{array}{r}\text { \# of obs } \\
\text { \# of countries }\end{array}$} & 547 & 547 & 547 & 547 & 528 & 528 \\
\hline & 19 & 19 & 19 & 19 & 19 & 19 \\
\hline$\#$ of debt restructuring obs. & 27 & 27 & 27 & 27 & 27 & 27 \\
\hline
\end{tabular}

Notes: The table shows local projections (AIPW) of the variables shown in each panel for $h=1,2, \ldots, 5$, where $h$ indicates horizon. All regressions include a constant term, lagged dependent variables (lag 1), cyclical component of log of GDP obtained from a HodrickPrescott filter with a smoothing parameter of 100 , and country fixed effects. Robust standard errors, clustered at the country-level, are in parentheses. ${ }^{* * *},{ }^{* *}$, and ${ }^{*}$ indicate statistical significance at 1 percent, 5 percent, and 10 percent level, respectively. 
Table D4: Debt Restructurings and Severe Sudden Stops, Panel OLS \& IV

Panel A: Dep. Var. = Annualized GDP Growth Rate from a Year Before and a Year After the Start of Restructurings, $100 \times\left[\ln \left(G D P_{i, t+2}\right)-\ln \left(G D P_{i, t}\right)\right] / 2$

\begin{tabular}{|c|c|c|c|c|c|c|}
\hline & \multicolumn{3}{|c|}{ OLS } & \multicolumn{3}{|c|}{ IV } \\
\hline & (1) & $(2)$ & (3) & (4) & $(5)$ & $(6)$ \\
\hline Post-default, d. $N C I<25$ th & $\begin{array}{c}-3.302 * * * \\
(1.070)\end{array}$ & $\begin{array}{c}-3.258^{* * *} \\
(1.001)\end{array}$ & $\begin{array}{c}-2.553 * * * \\
(0.989)\end{array}$ & $\begin{array}{c}-2.917 * * * \\
(1.131)\end{array}$ & $\begin{array}{c}-3.366^{* * *} \\
(0.993)\end{array}$ & $\begin{array}{c}-2.513 * * \\
(0.985)\end{array}$ \\
\hline Post-default, d. $N C I \geq 25$ th & $\begin{array}{c}-1.183 * * \\
(0.530)\end{array}$ & $\begin{array}{c}-1.098^{* *} \\
(0.545)\end{array}$ & $\begin{array}{l}-0.558 \\
(0.546)\end{array}$ & $\begin{array}{c}-1.217^{* *} \\
(0.553)\end{array}$ & $\begin{array}{l}-0.664 \\
(0.541)\end{array}$ & $\begin{array}{l}-0.256 \\
(0.535)\end{array}$ \\
\hline Weakly preemptive, d. $N C I<25$ th & $\begin{array}{l}-2.500^{*} \\
(1.379)\end{array}$ & $\begin{array}{l}-2.674 * \\
(1.364)\end{array}$ & $\begin{array}{l}-1.736 \\
(1.367)\end{array}$ & $\begin{array}{c}-3.591 * * \\
(1.530)\end{array}$ & $\begin{array}{c}-3.098^{* *} \\
(1.390)\end{array}$ & $\begin{array}{c}-1.94 \\
(1.404)\end{array}$ \\
\hline Weakly preemptive, d. $N C I \geq 25$ th & $\begin{array}{l}1.370^{*} \\
(0.786)\end{array}$ & $\begin{array}{l}1.322^{*} \\
(0.761)\end{array}$ & $\begin{array}{c}1.626^{* *} \\
(0.760)\end{array}$ & $\begin{array}{c}1.199 \\
(0.821)\end{array}$ & $\begin{array}{l}1.480^{*} \\
(0.762)\end{array}$ & $\begin{array}{c}1.884 * * \\
(0.767)\end{array}$ \\
\hline Strictly preemptive, d. $N C I<25$ th & $\begin{array}{c}-0.43 \\
(1.841)\end{array}$ & $\begin{array}{c}0.391 \\
(2.068)\end{array}$ & $\begin{array}{c}1.222 \\
(2.040)\end{array}$ & $\begin{array}{c}-0.352 \\
(1.870)\end{array}$ & $\begin{array}{c}1.826 \\
(2.014)\end{array}$ & $\begin{array}{c}2.861 \\
(1.990)\end{array}$ \\
\hline Strictly preemptive, d. $N C I \geq 25$ th & $\begin{array}{c}0.623 \\
(1.044)\end{array}$ & $\begin{array}{c}0.669 \\
(0.939)\end{array}$ & $\begin{array}{c}0.627 \\
(0.922)\end{array}$ & $\begin{array}{c}1.009 \\
(1.093)\end{array}$ & $\begin{array}{c}0.881 \\
(0.939)\end{array}$ & $\begin{array}{c}0.739 \\
(0.920)\end{array}$ \\
\hline \multicolumn{7}{|l|}{ Control variables } \\
\hline GDP growth rate, lag & $\begin{array}{c}0.616^{* * *} \\
(0.016)\end{array}$ & $\begin{array}{c}0.569 * * * \\
(0.022)\end{array}$ & $\begin{array}{c}0.547 * * * \\
(0.022)\end{array}$ & $\begin{array}{c}0.625 * * * \\
(0.016)\end{array}$ & $\begin{array}{c}0.575 * * * \\
(0.021)\end{array}$ & $\begin{array}{c}0.559 * * * \\
(0.021)\end{array}$ \\
\hline Investment-to-GDP ratio & & $\begin{array}{c}-0.038^{* *} \\
(0.015)\end{array}$ & $\begin{array}{c}-0.034 * * \\
(0.016)\end{array}$ & & $\begin{array}{c}-0.085^{* * *} \\
(0.017)\end{array}$ & $\begin{array}{c}-0.075^{* * *} \\
(0.018)\end{array}$ \\
\hline Population growth rate & & $\begin{array}{c}0.162 \\
(0.168)\end{array}$ & $\begin{array}{l}0.320^{*} \\
(0.167)\end{array}$ & & $\begin{array}{c}0.250 \\
(0.196)\end{array}$ & $\begin{array}{l}0.360^{*} \\
(0.196)\end{array}$ \\
\hline $\ln$ (Population) & & $\begin{array}{c}0.409 \\
(0.654)\end{array}$ & $\begin{array}{l}-1.502 \\
(1.032)\end{array}$ & & $\begin{array}{c}1.340 \\
(0.871)\end{array}$ & $\begin{array}{l}-2.327 \\
(1.425)\end{array}$ \\
\hline Government expenditure-to-GDP ratio & & $\begin{array}{c}0.018 \\
(0.026)\end{array}$ & $\begin{array}{c}0.014 \\
(0.026)\end{array}$ & & $\begin{array}{c}0.074 * * \\
(0.033)\end{array}$ & $\begin{array}{l}0.056^{*} \\
(0.034)\end{array}$ \\
\hline Humcan capital index & & $\begin{array}{l}-0.129 \\
(0.801)\end{array}$ & $\begin{array}{c}-2.224 * * \\
(0.995)\end{array}$ & & $\begin{array}{l}-0.843 \\
(1.032)\end{array}$ & $\begin{array}{c}-3.065^{* *} \\
(1.278)\end{array}$ \\
\hline Freedom house index, civil liberty & & $\begin{array}{l}-0.118 \\
(0.098)\end{array}$ & $\begin{array}{c}0.045 \\
(0.103)\end{array}$ & & $\begin{array}{c}-0.091 \\
(0.136)\end{array}$ & $\begin{array}{c}0.198 \\
(0.144)\end{array}$ \\
\hline Openness & & $\begin{array}{c}1.217^{*} \\
(0.690)\end{array}$ & $\begin{array}{c}0.814 \\
(0.754)\end{array}$ & & $\begin{array}{c}2.253 * * * \\
(0.820)\end{array}$ & $\begin{array}{c}1.839 * \\
(0.960)\end{array}$ \\
\hline Banking crisis dummy & & $\begin{array}{c}-0.734 * * \\
(0.310)\end{array}$ & $\begin{array}{c}-0.458 \\
(0.310) \\
\end{array}$ & & $\begin{array}{c}-1.191 * * * \\
(0.344) \\
\end{array}$ & $\begin{array}{c}-0.920 * * * \\
(0.346) \\
\end{array}$ \\
\hline$R$-squared & 0.401 & 0.36 & 0.41 & & & \\
\hline \# of obs. & 2,309 & 1,671 & 1,671 & 2,245 & 1,614 & 1,614 \\
\hline \# of countries & 64 & 53 & 53 & 64 & 52 & 52 \\
\hline \multicolumn{7}{|c|}{ Difference between point estimates for each strategy } \\
\hline Post-default, difference & $\begin{array}{c}-2.120^{*} \\
(1.185)\end{array}$ & $\begin{array}{l}-2.160^{*} \\
(1.126)\end{array}$ & $\begin{array}{c}-1.996^{*} \\
(1.110)\end{array}$ & $\begin{array}{l}-1.701 \\
(1.252)\end{array}$ & $\begin{array}{c}-2.701^{* *} \\
(1.125)\end{array}$ & $\begin{array}{c}-2.257^{* *} \\
(1.112)\end{array}$ \\
\hline \# of obs. from d. $N C I<25$ th & 15 & 13 & 13 & 15 & 13 & 13 \\
\hline$\#$ of obs. from d. $N C I \geq 25$ th & 62 & 45 & 45 & 62 & 45 & 45 \\
\hline Weakly preemptive, difference & $\begin{array}{c}-3.871 * * \\
(1.574)\end{array}$ & $\begin{array}{c}-3.996^{* * *} \\
(1.537)\end{array}$ & $\begin{array}{c}-3.362 * * \\
(1.523)\end{array}$ & $\begin{array}{c}-4.791 * * * \\
(1.679)\end{array}$ & $\begin{array}{c}-4.578 * * * \\
(1.539)\end{array}$ & $\begin{array}{c}-3.825^{* *} \\
(1.539)\end{array}$ \\
\hline$\#$ of obs. from d. $N C I<25$ th & 9 & 7 & 7 & 9 & 7 & 7 \\
\hline$\#$ of obs. from d. $N C I \geq 25 \mathrm{th}$ & 28 & 23 & 23 & 28 & 23 & 23 \\
\hline Strictly preemptive, difference & $\begin{array}{c}-1.053595 \\
(2.098)\end{array}$ & $\begin{array}{c}-0.278563 \\
(2.245)\end{array}$ & $\begin{array}{c}0.594545 \\
(2.212)\end{array}$ & $\begin{array}{c}-1.360431 \\
(2.102)\end{array}$ & $\begin{array}{c}0.945031 \\
(2.173)\end{array}$ & $\begin{array}{l}2.12126 \\
(2.142)\end{array}$ \\
\hline$\#$ of obs. from d. $N C I<25$ th & 5 & 3 & 3 & 5 & 3 & 3 \\
\hline \# of obs. from d. $N C I \geq 25$ th & 16 & 15 & 15 & 16 & 15 & 15 \\
\hline
\end{tabular}

Notes: The sample period is 1970-2013. All regressions include country fixed effects. Robust standard errors are in parentheses. ${ }^{* * *},{ }^{* *}$, and ${ }^{*}$ indicate the statistical significance at 1 percent, 5 percent, and 10 percent level, respectively. Debt restructuring samples are divided into two groups depending upon percentage point changes in the net capital inflows-to-GDP ratio from the pre-crisis level to 1 year after the crisis and the cutoff is the 25th percentile of distribution. IV columns report the results from the Arellano-Bond estimator, controlling for country fixed effects by taking first differences and first differences of independent variables are employed as IVs. 
Panel B: Dep. Var. = Annualized GDP Growth Rate from a Year Before and a Year After the Start of Restructurings, $100 \times\left[\right.$ Investment $_{i, t+2} / G D P_{i, t+2}-$ Investment $\left._{i, t} / G D P_{i, t}\right] / 2$

\begin{tabular}{|c|c|c|c|c|c|c|}
\hline & \multicolumn{3}{|c|}{ OLS } & \multicolumn{3}{|c|}{ IV } \\
\hline & $(1)$ & $(2)$ & (3) & $(4)$ & $(5)$ & $(6)$ \\
\hline Post-default, d.NCI $<25$ th & $\begin{array}{c}-3.894 * * * \\
(0.785)\end{array}$ & $\begin{array}{c}-3.917 * * * \\
(0.788)\end{array}$ & $\begin{array}{c}-3.554 * * * \\
(0.778)\end{array}$ & $\begin{array}{c}-3.751 * * * \\
(0.793)\end{array}$ & $\begin{array}{c}-4.410 * * * \\
(0.807)\end{array}$ & $\begin{array}{c}-4.139 * * * \\
(0.796)\end{array}$ \\
\hline Post-default, d. $N C I \geq 25$ th & $\begin{array}{c}-1.244 * * * \\
(0.398)\end{array}$ & $\begin{array}{c}-0.948 * * \\
(0.441)\end{array}$ & $\begin{array}{c}-0.603 \\
(0.442)\end{array}$ & $\begin{array}{c}-1.185^{* * *} \\
(0.406)\end{array}$ & $\begin{array}{l}-0.800^{*} \\
(0.452)\end{array}$ & $\begin{array}{l}-0.542 \\
(0.455)\end{array}$ \\
\hline Weakly preemptive, d. $N C I<25$ th & $\begin{array}{c}-2.794 * * * \\
(0.978)\end{array}$ & $\begin{array}{c}-2.757 * * \\
(1.075)\end{array}$ & $\begin{array}{c}-1.708 \\
(1.074)\end{array}$ & $\begin{array}{c}-3.349 * * * \\
(1.031)\end{array}$ & $\begin{array}{c}-3.285^{* * *} \\
(1.123)\end{array}$ & $\begin{array}{l}-2.117 * \\
(1.121)\end{array}$ \\
\hline Weakly preemptive, d. $N C I \geq 25$ th & $\begin{array}{c}0.614 \\
(0.589)\end{array}$ & $\begin{array}{c}0.386 \\
(0.599)\end{array}$ & $\begin{array}{c}0.639 \\
(0.598)\end{array}$ & $\begin{array}{c}0.79 \\
(0.595)\end{array}$ & $\begin{array}{c}0.469 \\
(0.618)\end{array}$ & $\begin{array}{c}0.8 \\
(0.624)\end{array}$ \\
\hline Strictly preemptive, d. $N C I<25$ th & $\begin{array}{c}-1.093 \\
(1.305)\end{array}$ & $\begin{array}{c}-0.84 \\
(1.630)\end{array}$ & $\begin{array}{c}-0.791 \\
(1.604)\end{array}$ & $\begin{array}{c}-0.454 \\
(1.277)\end{array}$ & $\begin{array}{c}-0.848 \\
(1.639)\end{array}$ & $\begin{array}{c}-0.628 \\
(1.606)\end{array}$ \\
\hline Strictly preemptive, d. $N C I \geq 25$ th & $\begin{array}{c}1.116 \\
(0.739)\end{array}$ & $\begin{array}{c}0.975 \\
(0.739)\end{array}$ & $\begin{array}{c}1.005 \\
(0.725)\end{array}$ & $\begin{array}{c}1.284^{*} \\
(0.748)\end{array}$ & $\begin{array}{c}1.266 \\
(0.771)\end{array}$ & $\begin{array}{c}1.232 \\
(0.757)\end{array}$ \\
\hline \multicolumn{7}{|l|}{ Control variables } \\
\hline GDP growth rate, lag & $\begin{array}{c}0.361 * * * \\
(0.021)\end{array}$ & $\begin{array}{c}0.480 * * * \\
(0.026)\end{array}$ & $\begin{array}{c}0.489 * * * \\
(0.027)\end{array}$ & $\begin{array}{c}0.359 * * * \\
(0.019)\end{array}$ & $\begin{array}{c}0.520 * * * \\
(0.026)\end{array}$ & $\begin{array}{c}0.543 * * * \\
(0.027)\end{array}$ \\
\hline Investment-to-GDP ratio & & $\begin{array}{c}-0.110 * * * \\
(0.013)\end{array}$ & $\begin{array}{c}-0.121 * * * \\
(0.014)\end{array}$ & & $\begin{array}{c}-0.195^{* * *} \\
(0.016)\end{array}$ & $\begin{array}{c}-0.213 * * * \\
(0.017)\end{array}$ \\
\hline Population growth rate & & $\begin{array}{c}0.029 \\
(0.132)\end{array}$ & $\begin{array}{c}0.090 \\
(0.131)\end{array}$ & & $\begin{array}{l}-0.121 \\
(0.162)\end{array}$ & $\begin{array}{c}0.047 \\
(0.160)\end{array}$ \\
\hline $\ln$ (Population) & & $\begin{array}{c}0.642 \\
(0.518)\end{array}$ & $\begin{array}{c}-0.259 \\
(0.813)\end{array}$ & & $\begin{array}{l}1.479 * \\
(0.771)\end{array}$ & $\begin{array}{c}0.473 \\
(1.181)\end{array}$ \\
\hline Government expenditure-to-GDP ratio & & $\begin{array}{l}-0.014 \\
(0.020)\end{array}$ & $\begin{array}{l}-0.022 \\
(0.020)\end{array}$ & & $\begin{array}{c}0.008 \\
(0.024)\end{array}$ & $\begin{array}{c}-0.011 \\
(0.024)\end{array}$ \\
\hline Humcan capital index & & $\begin{array}{c}-0.755 \\
(0.637)\end{array}$ & $\begin{array}{c}-2.169 * * * \\
(0.792)\end{array}$ & & $\begin{array}{c}-2.322 * * * \\
(0.883)\end{array}$ & $\begin{array}{c}-4.755^{* * *} \\
(1.181)\end{array}$ \\
\hline Freedom house index, civil liberty & & $\begin{array}{l}-0.075 \\
(0.077)\end{array}$ & $\begin{array}{c}0.015 \\
(0.081)\end{array}$ & & $\begin{array}{l}-0.123 \\
(0.118)\end{array}$ & $\begin{array}{c}-0.035 \\
(0.120)\end{array}$ \\
\hline Openness & & $\begin{array}{c}0.144 \\
(0.550)\end{array}$ & $\begin{array}{l}-0.988^{*} \\
(0.600)\end{array}$ & & $\begin{array}{l}1.309^{*} \\
(0.722)\end{array}$ & $\begin{array}{c}-0.458 \\
(0.790)\end{array}$ \\
\hline Banking crisis dummy & & $\begin{array}{c}-0.156 \\
(0.242) \\
\end{array}$ & $\begin{array}{c}0.124 \\
(0.243) \\
\end{array}$ & & $\begin{array}{c}-0.315 \\
(0.278) \\
\end{array}$ & $\begin{array}{c}0.166 \\
(0.280) \\
\end{array}$ \\
\hline$R$-squared & 0.156 & 0.202 & 0.268 & & & \\
\hline \# of obs. & 2,017 & 1,657 & 1,657 & 1,955 & 1,601 & 1,601 \\
\hline \# of countries & 61 & 52 & 52 & 60 & 52 & 52 \\
\hline \multicolumn{7}{|c|}{ Difference between point estimates for each strategy } \\
\hline Post-default, difference & $\begin{array}{c}-2.650 * * * \\
(0.874)\end{array}$ & $\begin{array}{c}-2.969 * * * \\
(0.895)\end{array}$ & $\begin{array}{c}-2.951 * * * \\
(0.879)\end{array}$ & $\begin{array}{c}-2.565^{* * *} \\
(0.890)\end{array}$ & $\begin{array}{c}-3.610 * * * \\
(0.922)\end{array}$ & $\begin{array}{c}-3.598 * * * \\
(0.906)\end{array}$ \\
\hline$\#$ of obs. from d. $N C I<25$ th & 14 & 13 & 13 & 14 & 13 & 13 \\
\hline \# of obs. from d. $N C I \geq 25$ th & 55 & 42 & 42 & 55 & 42 & 42 \\
\hline Weakly preemptive, difference & $\begin{array}{c}-3.409 * * * \\
(1.131)\end{array}$ & $\begin{array}{c}-3.143 * * * \\
(1.211)\end{array}$ & $\begin{array}{c}-2.347 * * * \\
(1.197)\end{array}$ & $\begin{array}{c}-4.138^{* * *} \\
(1.162)\end{array}$ & $\begin{array}{c}-3.755^{* * *} \\
(1.251)\end{array}$ & $\begin{array}{c}-2.917 * * * \\
(1.239)\end{array}$ \\
\hline$\#$ of obs. from d. $N C I<25$ th & 9 & 7 & 7 & 9 & 7 & 7 \\
\hline$\#$ of obs. from d. $N C I \geq 25$ th & 25 & 23 & 23 & 25 & 23 & 23 \\
\hline Strictly preemptive, difference & $\begin{array}{c}-2.209665 \\
(1.486)\end{array}$ & $\begin{array}{c}-1.814481 \\
(1.770)\end{array}$ & $\begin{array}{c}-1.796344 \\
(1.740)\end{array}$ & $\begin{array}{c}-1.737948 \\
(1.444)\end{array}$ & $\begin{array}{c}-2.114155 \\
(1.766)\end{array}$ & $\begin{array}{c}-1.859524 \\
(1.730)\end{array}$ \\
\hline$\#$ of obs. from d. $N C I<25$ th & 5 & 3 & 3 & 5 & 3 & 3 \\
\hline$\#$ of obs. from d. $N C I \geq 25$ th & 16 & 15 & 15 & 16 & 15 & 15 \\
\hline
\end{tabular}

Notes: The sample period is 1970-2013. All regressions include country fixed effects. Robust standard errors are in parentheses. ${ }^{* *},{ }^{* *}$, and ${ }^{*}$ indicate the statistical significance at 1 percent, 5 percent, and 10 percent level, respectively. Debt restructuring samples are divided into two groups depending upon percentage point changes in the net capital inflows-to-GDP ratio from the pre-crisis level to 1 year after the crisis and the cutoff is the 25th percentile of distribution. IV columns report the results from the Arellano-Bond estimator, controlling for country fixed effects by taking first differences and first differences of independent variables are employed as IVs. 
Panel C: Dep. Var. = Annualized Rate of Change in Private Credit from a Year Before and a Year After the Start of Restructurings, $100 \times\left[\ln \left(\right.\right.$ Credit $\left._{i, t+2}\right)-\ln \left(\right.$ Credit $\left.\left._{i, t}\right)\right] / 2$

\begin{tabular}{|c|c|c|c|c|c|c|}
\hline & \multicolumn{3}{|c|}{ OLS } & \multicolumn{3}{|c|}{ IV } \\
\hline & $(1)$ & $(2)$ & (3) & $(4)$ & $(5)$ & $(6)$ \\
\hline Post-default, d. $N C I<25$ th & $\begin{array}{c}-6.114 * * \\
(2.656)\end{array}$ & $\begin{array}{c}-6.574 * * \\
(2.622)\end{array}$ & $\begin{array}{c}-6.783 * * * \\
(2.621)\end{array}$ & $\begin{array}{c}-7.200 * * * \\
(2.629)\end{array}$ & $\begin{array}{c}-7.422 * * * \\
(2.515)\end{array}$ & $\begin{array}{c}-7.603 * * * \\
(2.515)\end{array}$ \\
\hline Post-default, d. $N C I \geq 25$ th & $\begin{array}{c}-5.546^{* * *} \\
(1.226)\end{array}$ & $\begin{array}{c}-5.651 * * * \\
(1.304)\end{array}$ & $\begin{array}{c}-4.967 * * * \\
(1.327)\end{array}$ & $\begin{array}{c}-5.781 * * * \\
(1.176)\end{array}$ & $\begin{array}{c}-5.658 * * * \\
(1.231)\end{array}$ & $\begin{array}{c}-5.124 * * * \\
(1.250)\end{array}$ \\
\hline Weakly preemptive, d. $N C I<25$ th & $\begin{array}{l}-4.757 \\
(2.924)\end{array}$ & $\begin{array}{l}-3.330 \\
(3.128)\end{array}$ & $\begin{array}{l}-1.986 \\
(3.180)\end{array}$ & $\begin{array}{l}-4.789 \\
(2.989)\end{array}$ & $\begin{array}{c}-4.874 \\
(3.081)\end{array}$ & $\begin{array}{c}-3.48 \\
(3.161)\end{array}$ \\
\hline Weakly preemptive, d. $N C I \geq 25$ th & $\begin{array}{c}0.444 \\
(1.667)\end{array}$ & $\begin{array}{c}1.355 \\
(1.747)\end{array}$ & $\begin{array}{c}1.690 \\
(1.773)\end{array}$ & $\begin{array}{c}0.296 \\
(1.593)\end{array}$ & $\begin{array}{c}1.096 \\
(1.637)\end{array}$ & $\begin{array}{l}1.173 \\
(1.661)\end{array}$ \\
\hline Strictly preemptive, d. $N C I<25$ th & $\begin{array}{l}-1.475 \\
(3.914)\end{array}$ & $\begin{array}{c}2.593 \\
(4.754)\end{array}$ & $\begin{array}{c}2.307 \\
(4.743)\end{array}$ & $\begin{array}{l}-0.590 \\
(3.673)\end{array}$ & $\begin{array}{c}3.769 \\
(4.353)\end{array}$ & $\begin{array}{c}2.801 \\
(4.359)\end{array}$ \\
\hline Strictly preemptive, d. $N C I \geq 25$ th & $\begin{array}{l}-3.045 \\
(2.286)\end{array}$ & $\begin{array}{l}-3.290 \\
(2.227)\end{array}$ & $\begin{array}{c}-2.304 \\
(2.215)\end{array}$ & $\begin{array}{c}-4.758 * * \\
(2.245)\end{array}$ & $\begin{array}{c}-4.723^{* *} \\
(2.137)\end{array}$ & $\begin{array}{l}-3.176 \\
(2.127)\end{array}$ \\
\hline \multicolumn{7}{|l|}{ Control variables } \\
\hline GDP growth rate, lag & $\begin{array}{c}0.614 * * * \\
(0.017)\end{array}$ & $\begin{array}{c}0.602 * * * \\
(0.020)\end{array}$ & $\begin{array}{c}0.600 * * * \\
(0.020)\end{array}$ & $\begin{array}{c}0.612 * * * \\
(0.015)\end{array}$ & $\begin{array}{c}0.597 * * * \\
(0.018)\end{array}$ & $\begin{array}{c}0.599 * * * \\
(0.018)\end{array}$ \\
\hline Investment-to-GDP ratio & & $\begin{array}{l}-0.039 \\
(0.038)\end{array}$ & $\begin{array}{l}-0.056 \\
(0.039)\end{array}$ & & $\begin{array}{c}-0.126 * * * \\
(0.044)\end{array}$ & $\begin{array}{c}-0.111 * * \\
(0.045)\end{array}$ \\
\hline Population growth rate & & $\begin{array}{c}0.222 \\
(0.422)\end{array}$ & $\begin{array}{c}0.401 \\
(0.424)\end{array}$ & & $\begin{array}{c}-0.274 \\
(0.484)\end{array}$ & $\begin{array}{c}-0.014 \\
(0.487)\end{array}$ \\
\hline $\ln$ (Population) & & $\begin{array}{c}1.706 \\
(1.629)\end{array}$ & $\begin{array}{l}-1.210 \\
(2.657)\end{array}$ & & $\begin{array}{c}1.775 \\
(2.068)\end{array}$ & $\begin{array}{l}-2.566 \\
(3.506)\end{array}$ \\
\hline Government expenditure-to-GDP ratio & & $\begin{array}{c}-0.207 * * * \\
(0.066)\end{array}$ & $\begin{array}{c}-0.208 * * * \\
(0.067)\end{array}$ & & $\begin{array}{c}-0.247 * * * \\
(0.078)\end{array}$ & $\begin{array}{c}-0.263 * * * \\
(0.080)\end{array}$ \\
\hline Humcan capital index & & $\begin{array}{l}-1.775 \\
(1.952)\end{array}$ & $\begin{array}{c}-3.9 \\
(2.459)\end{array}$ & & $\begin{array}{l}-3.171 \\
(2.465)\end{array}$ & $\begin{array}{c}-7.288 * * \\
(3.421)\end{array}$ \\
\hline Freedom house index, civil liberty & & $\begin{array}{c}0.502 * * \\
(0.248)\end{array}$ & $\begin{array}{c}0.739 * * * \\
(0.256)\end{array}$ & & $\begin{array}{c}1.033 * * * \\
(0.324)\end{array}$ & $\begin{array}{c}1.346^{* * *} \\
(0.337)\end{array}$ \\
\hline Openness & & $\begin{array}{l}3.065^{*} \\
(1.712)\end{array}$ & $\begin{array}{c}-0.064 \\
(1.923)\end{array}$ & & $\begin{array}{c}5.482 * * * \\
(2.015)\end{array}$ & $\begin{array}{l}-0.180 \\
(2.428)\end{array}$ \\
\hline Banking crisis dummy & & $\begin{array}{c}-3.981 * * * \\
(0.730) \\
\end{array}$ & $\begin{array}{c}-3.770 * * * \\
(0.738) \\
\end{array}$ & & $\begin{array}{c}-5.095 * * * \\
(0.751) \\
\end{array}$ & $\begin{array}{c}-4.913 * * * \\
(0.764) \\
\end{array}$ \\
\hline$R$-squared & 0.416 & 0.444 & 0.478 & & & \\
\hline \# of obs. & 2,047 & 1,561 & 1,561 & 1,974 & 1,500 & 1,500 \\
\hline \# of countries & 63 & 52 & 52 & 63 & 52 & 52 \\
\hline \multicolumn{7}{|c|}{ Difference between point estimates for each strategy } \\
\hline Post-default, difference & $\begin{array}{l}-0.567 \\
(2.910)\end{array}$ & $\begin{array}{l}-0.923 \\
(2.907)\end{array}$ & $\begin{array}{l}-1.816 \\
(2.901)\end{array}$ & $\begin{array}{l}-1.419 \\
(2.876)\end{array}$ & $\begin{array}{l}-1.763 \\
(2.791)\end{array}$ & $\begin{array}{l}-2.479 \\
(2.776)\end{array}$ \\
\hline \# of obs. from d. $N C I<25$ th & 11 & 10 & 10 & 11 & 10 & 10 \\
\hline$\#$ of obs. from d. $N C I \geq 25$ th & 52 & 41 & 41 & 52 & 41 & 41 \\
\hline Weakly preemptive, difference & $\begin{array}{c}-5.202 \\
(3.340)\end{array}$ & $\begin{array}{l}-4.685 \\
(3.525)\end{array}$ & $\begin{array}{l}-3.675 \\
(3.538)\end{array}$ & $\begin{array}{l}-5.085 \\
(3.302)\end{array}$ & $\begin{array}{l}-5.970 * \\
(3.393)\end{array}$ & $\begin{array}{l}-4.654 \\
(3.443)\end{array}$ \\
\hline$\#$ of obs. from d. $N C I<25$ th & 9 & 7 & 7 & 9 & 7 & 7 \\
\hline$\#$ of obs. from d. $N C I \geq 25$ th & 28 & 23 & 23 & 28 & 23 & 23 \\
\hline Strictly preemptive, difference & $\begin{array}{c}1.570 \\
(4.491)\end{array}$ & $\begin{array}{c}5.884 \\
(5.185)\end{array}$ & $\begin{array}{c}4.611 \\
(5.166)\end{array}$ & $\begin{array}{c}4.167 \\
(4.173)\end{array}$ & $\begin{array}{l}8.493^{*} \\
(4.742)\end{array}$ & $\begin{array}{c}5.977 \\
(4.743)\end{array}$ \\
\hline$\#$ of obs. from d. $N C I<25$ th & 5 & 3 & 3 & 5 & 3 & 3 \\
\hline \# of obs. from d. $N C I \geq 25$ th & 15 & 14 & 14 & 15 & 14 & 14 \\
\hline
\end{tabular}

Notes: The sample period is 1970-2013. All regressions include country fixed effects. Robust standard errors are in parentheses. ${ }^{* * *},{ }^{* *}$, and ${ }^{*}$ indicate the statistical significance at 1 percent, 5 percent, and 10 percent level, respectively. Debt restructuring samples are divided into two groups depending upon percentage point changes in the net capital inflows-to-GDP ratio from the pre-crisis level to 1 year after the crisis and the cutoff is the 25th percentile of distribution. IV columns report the results from the Arellano-Bond estimator, controlling for country fixed effects by taking first differences and first differences of independent variables are employed as IVs. 


\section{D.2. Duration, Haircuts and Missed Payments}

Table D5: First-Stage Regression Results, Predicting Post-default Debt Restructurings with High/Small GDP Forecasts, Long/Short Expected Durations, and High/Small Expected Haircuts

\begin{tabular}{|c|c|c|c|c|c|c|}
\hline & \multicolumn{2}{|c|}{ GDP Forecasts } & \multicolumn{2}{|c|}{ Expected Durations } & \multicolumn{2}{|c|}{ Expected Haircuts } \\
\hline & $(1)$ & $(2)$ & $(3)$ & $(4)$ & $(5)$ & $(6)$ \\
\hline GDP growth rate, lag & 0.0246 & $-0.049 * * *$ & $-0.026^{*}$ & $-0.145^{*}$ & $-0.030 * *$ & $-0.129 * *$ \\
\hline & $(0.033)$ & $(0.015)$ & $(0.015)$ & $(0.074)$ & $(0.015)$ & $(0.065)$ \\
\hline \multirow[t]{2}{*}{ Cyclical component of $\ln ($ GDP per capita), lag } & $-7.765^{*}$ & $2.706^{*}$ & -0.322 & $36.12 * * *$ & -0.166 & $27.17 * * *$ \\
\hline & $(4.065)$ & $(1.461)$ & $(1.634)$ & $(12.220)$ & $(1.640)$ & $(9.351)$ \\
\hline \multirow[t]{2}{*}{ \# of past post-default cases } & $1.769 * * *$ & $0.597 * * *$ & $0.592 * * *$ & $6.604 * * *$ & $0.615 * * *$ & $5.964 * * *$ \\
\hline & $(0.560)$ & $(0.132)$ & $(0.127)$ & $(1.948)$ & $(0.129)$ & $(1.880)$ \\
\hline \multirow[t]{2}{*}{ \# of past preemptive cases } & 4.847 & $0.351 *$ & $0.578 * * *$ & 51.53 & $0.498 * *$ & 45.73 \\
\hline & $(466)$ & $(0.182)$ & $(0.218)$ & $(5524)$ & $(0.202)$ & $(1829)$ \\
\hline \multirow[t]{2}{*}{ \# of past banking crises } & $-1.271 * * *$ & $-0.348 * * *$ & $-0.593 * * *$ & $-1.204 * *$ & $-0.504 * * *$ & $-1.339 * *$ \\
\hline & $(0.488)$ & $(0.068)$ & $(0.108)$ & $(0.472)$ & $(0.089)$ & $(0.543)$ \\
\hline \multirow[t]{2}{*}{ Interest payments-to-GDP ratio, lag } & $58.14 * * *$ & $11.06 * * *$ & $12.47 * * *$ & 31.17 & $12.96 * * *$ & 9.967 \\
\hline & $(19.11)$ & $(2.548)$ & $(2.724)$ & $(24.45)$ & $(2.795)$ & $(23.96)$ \\
\hline \multirow[t]{2}{*}{ External debt-to-GDP ratio, lag } & -1.299 & $-0.819 * * *$ & $-0.767 * *$ & 0.825 & $-0.948 * * *$ & 1.06 \\
\hline & $(0.820)$ & $(0.299)$ & $(0.311)$ & $(1.332)$ & $(0.337)$ & $(1.004)$ \\
\hline \multirow[t]{2}{*}{ Constant } & -12.73 & $-1.837 * * *$ & $-1.810 * * *$ & -62.63 & $-1.817 * * *$ & -56.31 \\
\hline & $(1129)$ & $(0.478)$ & $(0.510)$ & $(5579)$ & $(0.500)$ & $(1923)$ \\
\hline Pseudo $R$-sq. & 0.417 & 0.180 & 0.241 & 0.606 & 0.235 & 0.543 \\
\hline \multirow{2}{*}{$\begin{array}{r}\text { Log-likelihood ratio } \\
p \text {-value of log-likelihood ratio }\end{array}$} & 46.25 & 75.79 & 100.24 & 72.37 & 96.82 & 64.87 \\
\hline & 0.000 & 0.000 & 0.000 & 0.000 & 0.000 & 0.000 \\
\hline Observations & 456 & 1,260 & 1,276 & 481 & 1,235 & 481 \\
\hline Area under ROC curve & 0.95 & 0.84 & 0.87 & 0.98 & 0.87 & 0.97 \\
\hline
\end{tabular}

Notes: The table shows first-stage regression results for AIPW estimation. All regressions include a constant term and country fixed effects. Robust standard errors, clustered at the country-level, are in parentheses. ${ }^{* \star \star}$, ${ }^{\star *}$, and ${ }^{*}$ indicate statistical significance at 1 percent, 5 percent, and 10 percent level, respectively. The estimates are based on the same sample of restructuring observations. 
Figure D3: First-Stage Estimation Results, ROC

Panel I: GDP Forecasts
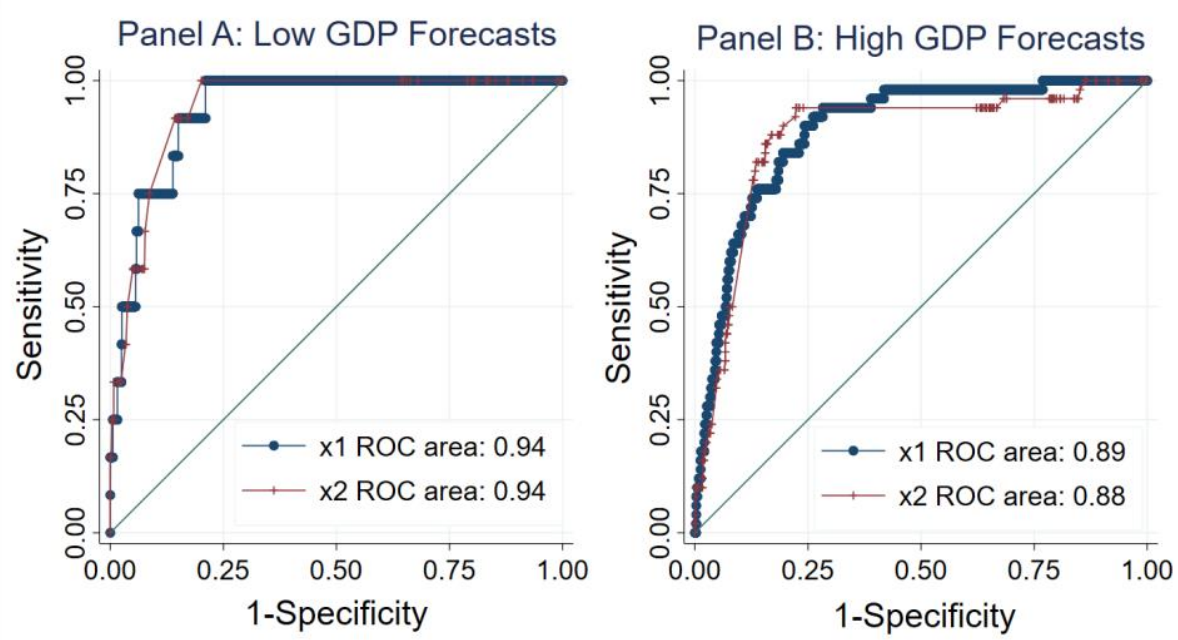

Panel II: Length of Duration
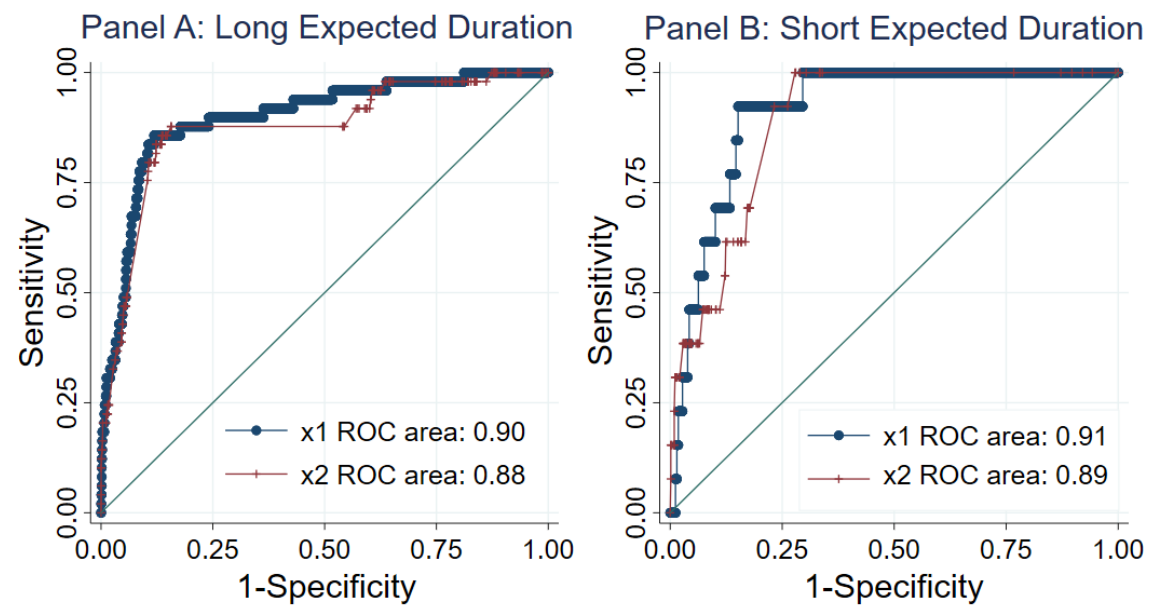

Panel III: Size of Haircuts
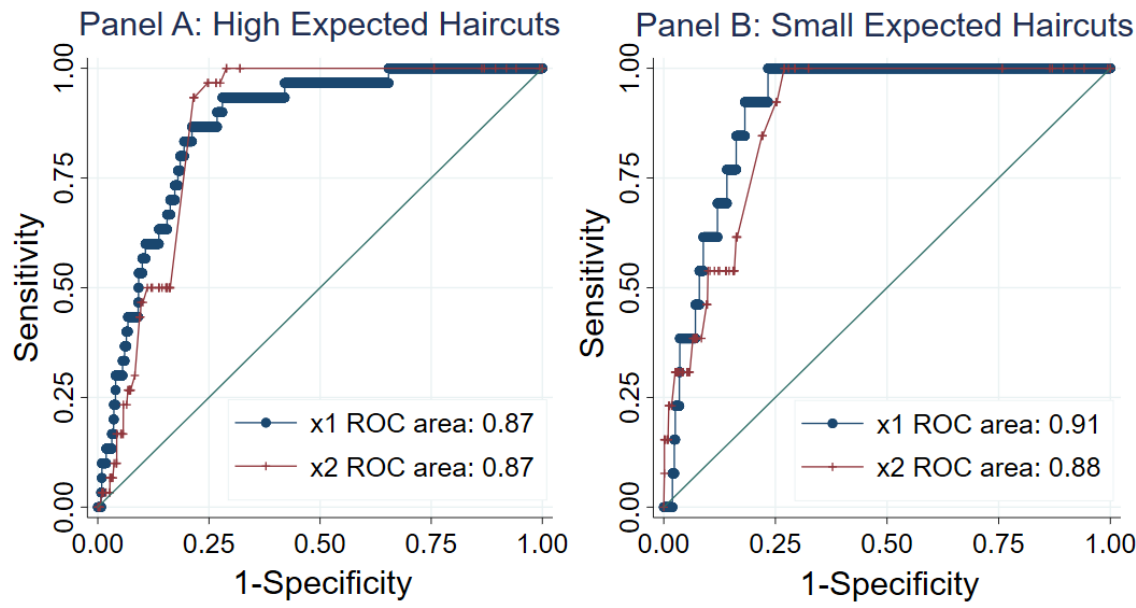

Notes: Panel I, II, and III show the area under the ROC curve. The ROC area takes a value between 0.50 and 1 . Taking a value of 0.50 indicates that regressors have no classification power when differentiating observations at the start of debt restructurings from other observations. Taking a value of 1 indicates that regressors have a perfect classification power. See the main text for the definition of $x 1$ and $x 2$. 
Figure D4: GDP after Post-default Restructurings

Panel I: AIPW, Allowing the First-Stage Parameters to differ across the Two Groups of Observations (Two-type Model)
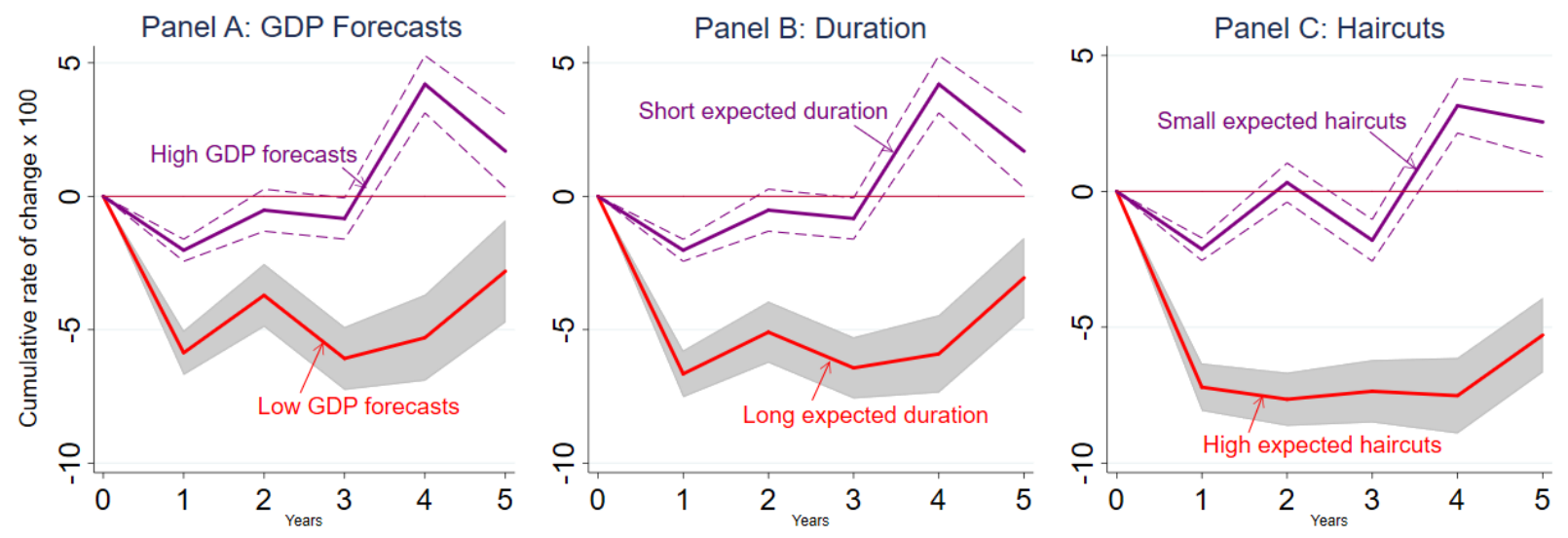

Panel II: AIPW, Assuming the Same First-Stage Parameters between the Two Groups of Observations (One-type Model)
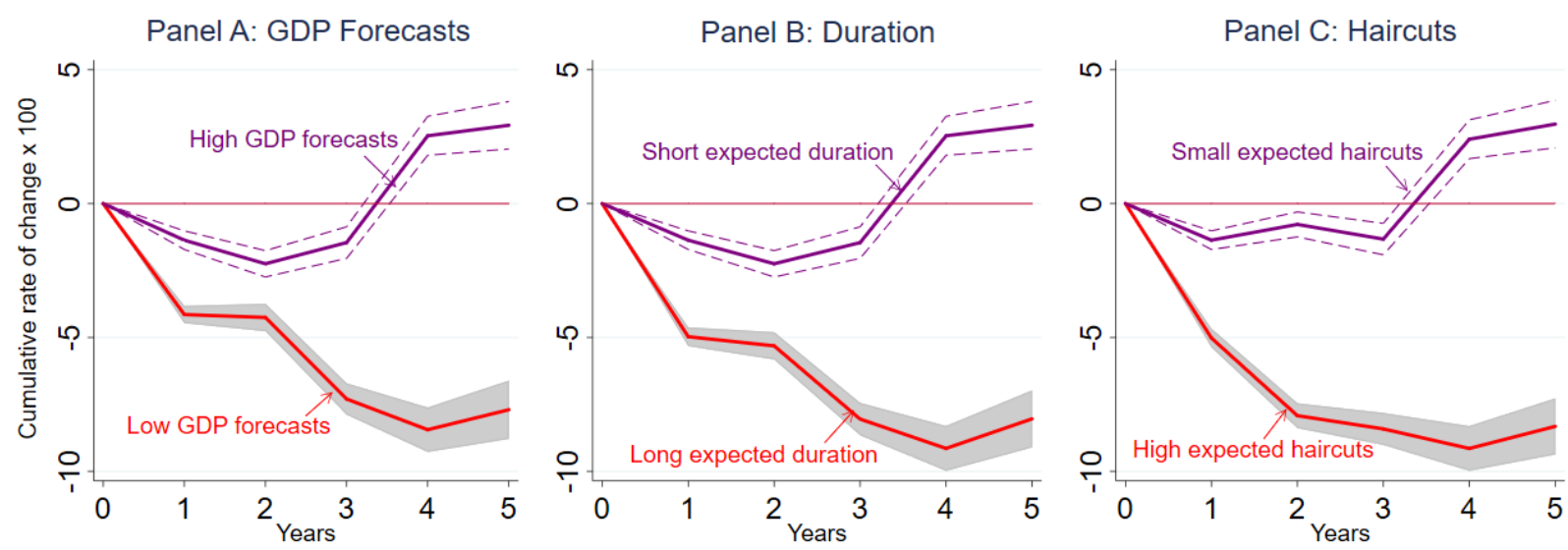

Panel III: OLS Local Projections
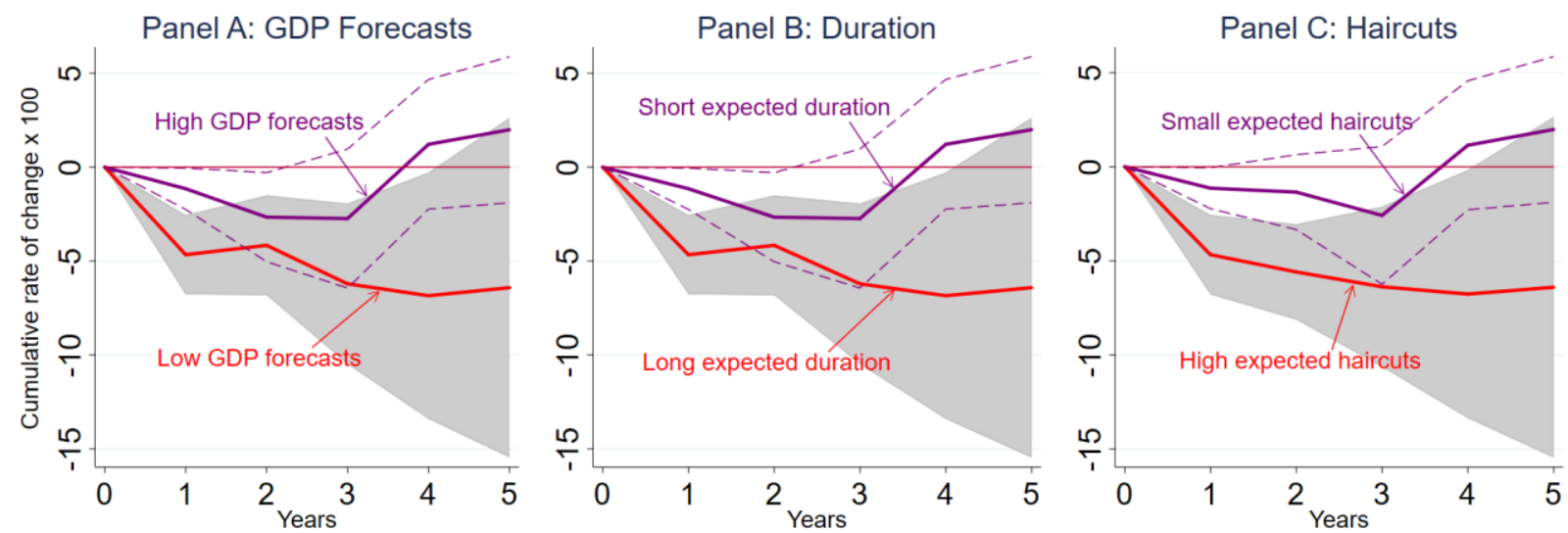

Notes: The figure shows dynamics of GDP after post-default debt restructurings, classifying the sample into those high and low GDP growth forecasts (Panel A), those with short and long expected duration (Panel B), and those with small and high expected haircuts (Panel C). Panel A classifies post-default restructurings into two groups based on the long-run GDP growth forecasts. Panel B and C classify post-default restructurings into two groups based on the estimated duration and haircuts obtained in columns (2) and (5) in Table 4, respectively. Solid lines in red and purple are point estimates. Gray bands and dotted lines in purple are 95 percent confidence intervals. 
Table D6: GDP after Post-default Debt Restructurings, AIPW, Allowing the First-Stage Parameters to Differ across the Two Groups of Observations (Two-type Model)

\begin{tabular}{|c|c|c|c|c|c|c|}
\hline \multicolumn{7}{|c|}{ Panel A: GDP Forecasts } \\
\hline & $h=1$ & $h=2$ & $h=3$ & $h=4$ & $h=5$ & Sum \\
\hline \multirow[t]{2}{*}{ Post-default, with lower GDP forecasts } & $-5.866^{* * *}$ & $-3.713^{* * *}$ & $-6.078 * * *$ & $-5.301 * * *$ & $-2.809^{* * *}$ & $-22.85 * * *$ \\
\hline & $(0.425)$ & $(0.603)$ & $(0.602)$ & $(0.823)$ & $(0.979)$ & $(2.942)$ \\
\hline \multirow{2}{*}{$\begin{array}{r}\text { \# of obs. } \\
\text { \# of countries }\end{array}$} & 446 & 446 & 434 & 422 & 410 & 410 \\
\hline & 12 & 12 & 12 & 12 & 12 & 12 \\
\hline \# of debt restructuring obs. & 12 & 12 & 12 & 12 & 12 & 12 \\
\hline \multirow[t]{2}{*}{ Post-default, with higher GDP forecasts } & $-2.023 * * *$ & -0.520 & $-0.833^{* *}$ & $4.202 * * *$ & $1.693 * *$ & 2.826 \\
\hline & $(0.211)$ & $(0.402)$ & $(0.393)$ & $(0.548)$ & $(0.702)$ & $(1.873)$ \\
\hline \# of obs. & 394 & 394 & 381 & 368 & 355 & 355 \\
\hline \# of countries & 13 & 13 & 13 & 13 & 13 & 13 \\
\hline$\#$ of debt restructuring obs. & 13 & 13 & 13 & 13 & 13 & 13 \\
\hline
\end{tabular}

Panel B: Duration

\begin{tabular}{|c|c|c|c|c|c|c|}
\hline & $h=1$ & $h=2$ & $h=3$ & $h=4$ & $h=5$ & Sum \\
\hline Post-default, with longer expected duration & $\begin{array}{c}-6.656^{* * *} \\
(0.449)\end{array}$ & $\begin{array}{c}-5.093 * * * \\
(0.586)\end{array}$ & $\begin{array}{c}-6.432 * * * \\
(0.586)\end{array}$ & $\begin{array}{c}-5.908 * * * \\
(0.742)\end{array}$ & $\begin{array}{c}-3.058 * * * \\
(0.768)\end{array}$ & $\begin{array}{c}-26.09^{* * *} \\
(2.677)\end{array}$ \\
\hline \# of obs. & 437 & 437 & 425 & 413 & 401 & 401 \\
\hline \# of countries & 12 & 12 & 12 & 12 & 12 & 12 \\
\hline \# of debt restructuring obs. & 12 & 12 & 12 & 12 & 12 & 12 \\
\hline \multirow[t]{2}{*}{ Post-default, with shorter expected duration } & $-2.023 * * *$ & -0.520 & $-0.833 * *$ & $4.203 * * *$ & $1.693 * *$ & 2.826 \\
\hline & $(0.211)$ & $(0.402)$ & $(0.393)$ & $(0.548)$ & $(0.702)$ & $(1.873)$ \\
\hline \# of obs. & 394 & 394 & 381 & 368 & 355 & 355 \\
\hline \# of countries & 13 & 13 & 13 & 13 & 13 & 13 \\
\hline \# of debt restructuring obs. & 13 & 13 & 13 & 13 & 13 & 13 \\
\hline \multicolumn{7}{|c|}{ Panel C: Haircuts } \\
\hline & $h=1$ & $h=2$ & $h=3$ & $h=4$ & $h=5$ & Sum \\
\hline \multirow[t]{2}{*}{ Post-default, with higher expected haircuts } & $-7.207 * * *$ & $-7.652 * * *$ & $-7.357 * * *$ & $-7.519 * * *$ & $-5.292 * * *$ & $-34.08 * * *$ \\
\hline & $(0.447)$ & $(0.500)$ & $(0.586)$ & $(0.711)$ & $(0.700)$ & $(2.426)$ \\
\hline \# of obs. & 437 & 437 & 425 & 413 & 401 & 401 \\
\hline \# of countries & 12 & 12 & 12 & 12 & 12 & 12 \\
\hline \# of debt restructuring obs. & 12 & 12 & 12 & 12 & 12 & 12 \\
\hline Post-default, with lower expected haircuts & $\begin{array}{c}-2.129 * * * \\
(0.212)\end{array}$ & $\begin{array}{c}0.326 \\
(0.366)\end{array}$ & $\begin{array}{c}-1.799 * * * \\
(0.391)\end{array}$ & $\begin{array}{c}3.155 * * * \\
(0.514)\end{array}$ & $\begin{array}{c}2.554 * * * \\
(0.657)\end{array}$ & $\begin{array}{c}2.620 \\
(1.703)\end{array}$ \\
\hline \# of obs. & 413 & 413 & 400 & 387 & 374 & 374 \\
\hline \# of countries & 13 & 13 & 13 & 13 & 13 & 13 \\
\hline \# of debt restructuring obs. & 13 & 13 & 13 & 13 & 13 & 13 \\
\hline
\end{tabular}

Notes: The table shows local projections (AIPW) of the variables shown in each panel for $h=1,2, \ldots, 5$, where $h$ indicates horizon. All regressions include a constant term, lagged dependent variables (lag 1), cyclical component of log of GDP obtained from a HodrickPrescott filter with a smoothing parameter of 100 , and country fixed effects. Robust standard errors, clustered at the country-level, are in parentheses. ${ }^{* * *},{ }^{* *}$, and * indicate statistical significance at 1 percent, 5 percent, and 10 percent level, respectively. The estimates are based on the same sample of restructuring observations. 
Table D7: GDP after Post-default Debt Restructurings, AIPW, Assuming the Identical First-Stage Parameters between the Two of Observations (One-type Model)

\begin{tabular}{|c|c|c|c|c|c|c|}
\hline \multicolumn{7}{|c|}{ Panel A: GDP Forecasts } \\
\hline & $h=1$ & $h=2$ & $h=3$ & $h=4$ & $h=5$ & Sum \\
\hline \multirow[t]{2}{*}{ Post-default, with lower GDP forecasts } & $-4.144 * * *$ & $-4.254 * * *$ & $-7.297 * * *$ & $-8.446 * * *$ & $-7.700 * * *$ & $-30.70 * * *$ \\
\hline & $(0.165)$ & $(0.262)$ & $(0.300)$ & $(0.424)$ & $(0.556)$ & $(1.458)$ \\
\hline \# of obs. & 1467 & 1467 & 1429 & 1391 & 1353 & 1353 \\
\hline \# of countries & 38 & 38 & 38 & 38 & 38 & 38 \\
\hline \# of debt restructuring obs. & 12 & 12 & 12 & 12 & 12 & 12 \\
\hline \multirow[t]{2}{*}{ Post-default, with higher GDP forecasts } & $-1.366^{* * *}$ & $-2.249 * * *$ & $-1.458 * * *$ & $2.532 * * *$ & $2.925 * * *$ & 1.148 \\
\hline & $(0.178)$ & $(0.251)$ & $(0.301)$ & $(0.371)$ & $(0.452)$ & $(1.303)$ \\
\hline \# of obs. & 1438 & 1438 & 1400 & 1362 & 1324 & 1324 \\
\hline \# of countries & 38 & 38 & 38 & 38 & 38 & 38 \\
\hline \# of debt restructuring obs. & 13 & 13 & 13 & 13 & 13 & 13 \\
\hline
\end{tabular}

Panel B: Duration

\begin{tabular}{|c|c|c|c|c|c|c|}
\hline & $h=1$ & $h=2$ & $h=3$ & $h=4$ & $h=5$ & Sum \\
\hline \multirow[t]{2}{*}{ Post-default, with longer expected duration } & $-4.972 * * *$ & $-5.313 * * *$ & $-8.048 * * *$ & $-9.144 * * *$ & $-8.039 * * *$ & $-34.50 * * *$ \\
\hline & $(0.180)$ & $(0.261)$ & $(0.309)$ & $(0.428)$ & $(0.544)$ & $(1.486)$ \\
\hline \# of obs. & 1438 & 1438 & 1400 & 1362 & 1324 & 1324 \\
\hline \# of countries & 38 & 38 & 38 & 38 & 38 & 38 \\
\hline \# of debt restructuring obs. & 12 & 12 & 12 & 12 & 12 & 12 \\
\hline \multirow[t]{2}{*}{ Post-default, with shorter expected duration } & $-1.366 * * *$ & $-2.249 * * *$ & $-1.458 * * *$ & $2.532 * * *$ & $2.925 * * *$ & 1.148 \\
\hline & $(0.178)$ & $(0.251)$ & $(0.301)$ & $(0.371)$ & $(0.452)$ & $(1.303)$ \\
\hline \# of obs. & 1438 & 1438 & 1400 & 1362 & 1324 & 1324 \\
\hline \# of countries & 38 & 38 & 38 & 38 & 38 & 38 \\
\hline \# of debt restructuring obs. & 13 & 13 & 13 & 13 & 13 & 13 \\
\hline \multicolumn{7}{|c|}{ Panel C: Haircuts } \\
\hline & $h=1$ & $h=2$ & $h=3$ & $h=4$ & $h=5$ & Sum \\
\hline \multirow[t]{2}{*}{ Post-default, with higher expected haircuts } & $-5.019 * * *$ & $-7.922 * * *$ & $-8.416^{* * *}$ & $-9.145^{* * *}$ & $-8.322 * * *$ & $-37.89^{* * *}$ \\
\hline & $(0.179)$ & $(0.238)$ & $(0.306)$ & $(0.426)$ & $(0.535)$ & $(1.416)$ \\
\hline \# of obs. & 1438 & 1438 & 1400 & 1362 & 1324 & 1324 \\
\hline \# of countries & 38 & 38 & 38 & 38 & 38 & 38 \\
\hline \# of debt restructuring obs. & 12 & 12 & 12 & 12 & 12 & 12 \\
\hline \multirow[t]{2}{*}{ Post-default, with lower expected haircuts } & $-1.366^{* * *}$ & $-0.777 * * *$ & $-1.327 * * *$ & $2.404 * * *$ & $2.970 * * *$ & $2.729^{* *}$ \\
\hline & $(0.178)$ & $(0.237)$ & $(0.299)$ & $(0.371)$ & $(0.452)$ & $(1.300)$ \\
\hline \# of obs. & 1438 & 1438 & 1400 & 1362 & 1324 & 1324 \\
\hline \# of countries & 38 & 38 & 38 & 38 & 38 & 38 \\
\hline \# of debt restructuring obs. & 13 & 13 & 13 & 13 & 13 & 13 \\
\hline
\end{tabular}

Notes: The table shows local projections (AIPW) of the variables shown in each panel for $h=1,2, \ldots, 5$, where $h$ indicates horizon. All regressions include a constant term, lagged dependent variables (lag 1), cyclical component of log of GDP obtained from a HodrickPrescott filter with a smoothing parameter of 100 , and country fixed effects. Robust standard errors, clustered at the country-level, are in parentheses. ${ }^{* *},{ }^{* *}$, and ${ }^{*}$ indicate statistical significance at 1 percent, 5 percent, and 10 percent level, respectively. The estimates are based on the same sample of restructuring observations. 
Table D8: GDP after Post-default Debt Restructurings, OLS Local Projections

\begin{tabular}{|c|c|c|c|c|c|c|}
\hline \multicolumn{7}{|c|}{ Panel A: GDP Forecasts } \\
\hline & $h=1$ & $h=2$ & $h=3$ & $h=4$ & $h=5$ & Sum \\
\hline \multirow[t]{2}{*}{ Post-default, with lower GDP forecats } & $-4.661 * * *$ & $-4.161 * * *$ & $-6.214 * * *$ & $-6.845 * *$ & -6.417 & $-27.77 * *$ \\
\hline & $(1.079)$ & $(1.356)$ & $(2.184)$ & $(3.348)$ & $(4.616)$ & $(10.690)$ \\
\hline \multirow[t]{2}{*}{ Post-default, with higher GDP forecats } & $-1.148 * *$ & $-2.661 * *$ & -2.735 & 1.216 & 1.993 & -2.496 \\
\hline & $(0.561)$ & $(1.209)$ & (1.889) & $(1.760)$ & $(1.985)$ & $(5.684)$ \\
\hline \multirow{3}{*}{$\begin{array}{r}R \text {-squared } \\
\text { \# of obs. } \\
\text { \# of countries }\end{array}$} & 0.323 & 0.495 & 0.597 & 0.620 & 0.600 & 0.661 \\
\hline & 2,102 & 2,102 & 2,043 & 1,984 & 1,925 & 1,925 \\
\hline & 59 & 59 & 59 & 59 & 59 & 59 \\
\hline \multicolumn{7}{|c|}{ Panel B: Duration } \\
\hline & $h=1$ & $h=2$ & $h=3$ & $h=4$ & $h=5$ & Sum \\
\hline \multirow[t]{2}{*}{ Post-default, with longer expected duration } & $-4.661 * * *$ & $-4.161 * * *$ & $-6.214 * * *$ & $-6.845 * *$ & -6.417 & $-27.77 * *$ \\
\hline & $(1.079)$ & $(1.356)$ & $(2.184)$ & $(3.348)$ & $(4.616)$ & $(10.690)$ \\
\hline \multirow[t]{2}{*}{ Post-default, with shorter expected duration } & $-1.148 * *$ & $-2.661 * *$ & -2.735 & 1.216 & 1.993 & -2.496 \\
\hline & $(0.561)$ & $(1.209)$ & $(1.889)$ & $(1.760)$ & $(1.985)$ & $(5.684)$ \\
\hline \multirow{3}{*}{$\begin{array}{r}R \text {-squared } \\
\# \text { of obs. } \\
\text { \# of countries }\end{array}$} & 0.322 & 0.495 & 0.596 & 0.620 & 0.601 & 0.661 \\
\hline & 2,102 & 2,102 & 2,043 & 1,984 & 1,925 & 1,925 \\
\hline & 59 & 59 & 59 & 59 & 59 & 59 \\
\hline \multicolumn{7}{|c|}{ Panel C: Haircuts } \\
\hline & $h=1$ & $h=2$ & $h=3$ & $h=4$ & $h=5$ & Sum \\
\hline \multirow[t]{2}{*}{ Post-default, with higher expected haircuts } & $-4.671 * * *$ & $-5.589 * * *$ & $-6.378^{* * *}$ & $-6.763 * *$ & -6.404 & $-29.31 * * *$ \\
\hline & $(1.078)$ & $(1.294)$ & $(2.172)$ & $(3.364)$ & $(4.615)$ & $(10.320)$ \\
\hline \multirow[t]{2}{*}{ Post-default, with lower expected haircuts } & $-1.139 * *$ & -1.348 & -2.585 & 1.139 & 1.98 & -1.08 \\
\hline & $(0.556)$ & $(1.014)$ & $(1.866)$ & $(1.747)$ & $(1.973)$ & $(5.653)$ \\
\hline$R$-squared & 0.322 & 0.496 & 0.597 & 0.620 & 0.601 & 0.661 \\
\hline \# of obs. & 2,102 & 2,102 & 2,043 & 1,984 & 1,925 & 1,925 \\
\hline \# of countries & 59 & 59 & 59 & 59 & 59 & 59 \\
\hline
\end{tabular}

Notes: The table shows local projections (AIPW) of the variables shown in each panel for $h=1,2, \ldots, 5$, where $h$ indicates horizon. All regressions include a constant term, lagged dependent variables (lag 1), cyclical component of log of GDP obtained from a HodrickPrescott filter with a smoothing parameter of 100 , and country fixed effects. Robust standard errors, clustered at the country-level, are in parentheses. ${ }^{* * *},{ }^{* *}$, and ${ }^{*}$ indicate statistical significance at 1 percent, 5 percent, and 10 percent level, respectively. The estimates are based on the same sample of restructuring observations 


\section{Appendix E. Robustness Checks}

\section{E.1. Large Sample Including Countries without Restructurings}

Previous studies on sovereign defaults use a wider coverage of countries including those that have never defaulted: on defaults on private external debt, Furceri and Zdzienicka (2012) and Kuvshinov and Zimmermann (2016) use a sample of 154 countries and 114 countries, respectively. We set our sample to follow as close as possible the conventional approach in these studies. We exclude high income countries where the Purchasing Power Parity (PPP) adjusted GDP per capita is higher than the 80th percentile of the entire sample in 2000 since we do not have any restructuring episodes for advanced economies (Greece's 2011-12 restructuring takes place outside of the time sample used in this paper). That leaves 122 countries in the sample, a similar number to that in Furceri and Zdzienicka (2012) and Kuvshinov and Zimmermann (2016).

Figure E1 and Table E1 report the OLS estimates for GDP, investment, private credit, lending interest rates and net capital inflows - since we include country sample which restructuring dummies indicate 0 , we cannot apply AIPW but OLS. The results are quantitatively similar to Figure 7 and Table $\mathrm{C} 1$ confirming the robustness of our baseline (AIPW) results.

Table E1: Estimation Results with Expanded Sample, OLS

\begin{tabular}{|c|c|c|c|c|c|c|}
\hline & $h=1$ & $h=2$ & $h=3$ & $h=4$ & $h=5$ & Sum \\
\hline Post-default & $\begin{array}{c}-1.978 * * * \\
(0.706)\end{array}$ & $\begin{array}{c}-3.181 * * * \\
(0.771)\end{array}$ & $\begin{array}{c}-3.337 * * * \\
(0.735)\end{array}$ & $\begin{array}{c}-2.859 * * \\
(1.150)\end{array}$ & $\begin{array}{l}-2.285 \\
(1.997)\end{array}$ & $\begin{array}{c}-13.22 * * * \\
(3.704)\end{array}$ \\
\hline Weakly preemptive & $\begin{array}{c}-1.736^{* * *} \\
(0.660)\end{array}$ & $\begin{array}{c}-1.948^{* *} \\
(0.911)\end{array}$ & $\begin{array}{c}-1.208 \\
(1.356)\end{array}$ & $\begin{array}{c}-0.797 \\
(2.013)\end{array}$ & $\begin{array}{l}-2.003 \\
(2.199)\end{array}$ & $\begin{array}{l}-7.700 \\
(6.011)\end{array}$ \\
\hline Strictly preemptive & $\begin{array}{c}-1.757^{* * *} \\
(0.558) \\
\end{array}$ & $\begin{array}{c}-1.313 \\
(1.086) \\
\end{array}$ & $\begin{array}{l}-0.777 \\
(1.402) \\
\end{array}$ & $\begin{array}{r}-0.619 \\
(1.283) \\
\end{array}$ & $\begin{array}{r}-0.698 \\
(1.916) \\
\end{array}$ & $\begin{array}{r}-5.095 \\
(3.351) \\
\end{array}$ \\
\hline$R$-squared & 0.418 & 0.566 & 0.611 & 0.595 & 0.527 & 0.662 \\
\hline \# of countries & 115 & 115 & 115 & 115 & 115 & 115 \\
\hline \# of observations & 3,834 & 3,834 & 3,719 & 3,604 & 3,489 & 3,489 \\
\hline \multicolumn{7}{|c|}{ Panel B: Dep. Var. $=100 \times\left(\right.$ Investment $_{i, t+h} / G D P_{i, t+h}-$ Investment $\left._{i, t} / G D P_{i, t}\right)$} \\
\hline & $h=1$ & $h=2$ & $h=3$ & $h=4$ & $h=5$ & Sum \\
\hline Post-default & $\begin{array}{c}-1.806^{* *} \\
(0.810)\end{array}$ & $\begin{array}{c}-3.179 * * * \\
(0.945)\end{array}$ & $\begin{array}{c}-1.920 * * \\
(0.960)\end{array}$ & $\begin{array}{l}-1.455 \\
(0.899)\end{array}$ & $\begin{array}{c}-2.160 * * \\
(0.971)\end{array}$ & $\begin{array}{c}-10.30^{* * * *} \\
(3.713)\end{array}$ \\
\hline Weakly preemptive & $\begin{array}{c}-1.876^{* * * *} \\
(0.713)\end{array}$ & $\begin{array}{c}-2.463 * * \\
(1.064)\end{array}$ & $\begin{array}{c}-2.117 * * \\
(0.973)\end{array}$ & $\begin{array}{c}-2.080^{* *} \\
(0.971)\end{array}$ & $\begin{array}{c}-2.643 * * \\
(1.310)\end{array}$ & $\begin{array}{c}-11.34 * * \\
(4.355)\end{array}$ \\
\hline Strictly preemptive & $\begin{array}{r}-0.788 \\
(0.533) \\
\end{array}$ & $\begin{array}{r}0.700 \\
(0.951) \\
\end{array}$ & $\begin{array}{l}2.040^{*} \\
(1.105) \\
\end{array}$ & $\begin{array}{l}2.026^{*} \\
(1.195) \\
\end{array}$ & $\begin{array}{l}1.726^{*} \\
(0.957) \\
\end{array}$ & $\begin{array}{c}5.594 \\
(3.745) \\
\end{array}$ \\
\hline$R$-squared & 0.069 & 0.103 & 0.143 & 0.161 & 0.149 & 0.178 \\
\hline \# of countries & 109 & 109 & 109 & 109 & 109 & 109 \\
\hline$\#$ of observations & 3,431 & 3,425 & 3,313 & 3,201 & 3,091 & 3,085 \\
\hline
\end{tabular}

Notes: The table shows local projections (OLS) of the variables shown in each panel for $h=1,2, \ldots, 5$, where $h$ indicates horizon. All regressions include a constant term, lagged dependent variables (lag 1 and lag 2), cyclical component of log of GDP obtained from a Hodrick-Prescott filter with a smoothing parameter of 100 , and country fixed effects. Robust standard errors, clustered at the countrylevel, are in parentheses. ${ }^{* *},{ }^{* *}$, and ${ }^{*}$ indicate statistical significance at 1 percent, 5 percent, and 10 percent level, respectively. 
Panel C: Dep. Var. $=100 \times\left(\right.$ Credit $_{i, t+h} / G D P_{i, t+h}-$ Credit $\left._{i, t} / G D P_{i, t}\right)$

\begin{tabular}{rcccccc}
\hline & $h=1$ & $h=2$ & $h=3$ & $h=4$ & $h=5$ & Sum \\
\hline Post-default & -0.031 & $-1.943^{* * *}$ & $-2.778^{* * *}$ & $-3.218^{* * *}$ & $-3.788^{* * *}$ & $-11.97^{* * *}$ \\
& $(0.368)$ & $(0.523)$ & $(0.648)$ & $(0.848)$ & $(0.806)$ & $(2.910)$ \\
Weakly preemptive & -0.157 & $-1.475^{* *}$ & $-2.026^{* *}$ & $-2.400^{*}$ & $-2.868^{*}$ & $-9.128^{* *}$ \\
& $(0.451)$ & $(0.672)$ & $(1.010)$ & $(1.417)$ & $(1.588)$ & $(4.584)$ \\
Strictly preemptive & 0.227 & $-0.867^{* *}$ & -0.865 & -0.800 & -1.155 & -3.388 \\
& $(0.330)$ & $(0.411)$ & $(1.564)$ & $(2.325)$ & $(3.423)$ & $(8.256)$ \\
\hline$R$-squared & 0.100 & 0.062 & 0.051 & 0.043 & 0.036 & 0.070 \\
\# of countries & 113 & 113 & 113 & 113 & 112 & 112 \\
\# of observations & 3,421 & 3,410 & 3,294 & 3,178 & 3,064 & 3,018 \\
\hline
\end{tabular}

Panel D: Dep. Var. $=100 \times\left(\right.$ LendingRate $_{i, t+h}-$ LendingRate $\left._{i, t}\right)$

\begin{tabular}{rcccccc}
\hline & $h=1$ & $h=2$ & $h=3$ & $h=4$ & $h=5$ & Sum \\
\hline Post-default & $4.54^{* *}$ & $10.55^{* *}$ & $10.34^{* * *}$ & $9.88^{* *}$ & $12.09^{* *}$ & $48.77^{* * *}$ \\
& $(2.08)$ & $(4.22)$ & $(3.50)$ & $(4.18)$ & $(4.94)$ & $(18.39)$ \\
Weakly preemptive & 8.71 & 11.26 & 10.87 & 13.26 & 18.36 & 76.76 \\
& $(5.73)$ & $(9.29)$ & $(8.32)$ & $(9.39)$ & $(11.13)$ & $(50.89)$ \\
Strictly preemptive & 3.98 & 7.25 & 3.43 & -0.60 & -1.79 & 15.75 \\
& $(2.63)$ & $(5.96)$ & $(3.44)$ & $(3.88)$ & $(5.22)$ & $(16.04)$ \\
\hline$R$-squared & 0.117 & 0.218 & 0.481 & 0.503 & 0.511 & 0.412 \\
\# of countries & 98 & 97 & 97 & 97 & 97 & 97 \\
\# of observations & 1,880 & 1,856 & 1,754 & 1,656 & 1,560 & 1,524 \\
\hline
\end{tabular}

Panel E: Dep. Var. $=100 \times\left(N C I_{i, t+h} / G D P_{i, t+h}-N C I_{i, t} / G D P_{i, t}\right)$

\begin{tabular}{rcccccc}
\hline & $h=1$ & $h=2$ & $h=3$ & $h=4$ & $h=5$ & Sum \\
\hline Post-default & $-2.458^{* *}$ & $-4.784^{* * *}$ & -0.258 & -2.029 & $-3.754^{* * *}$ & $-14.16^{* * *}$ \\
& $(1.190)$ & $(1.820)$ & $(2.508)$ & $(1.634)$ & $(1.327)$ & $(5.242)$ \\
Weakly preemptive & $-6.123^{* * *}$ & $-4.919 * *$ & -3.543 & $-5.065^{*}$ & -4.512 & $-22.62^{* *}$ \\
& $(1.569)$ & $(2.194)$ & $(2.362)$ & $(2.586)$ & $(3.250)$ & $(9.833)$ \\
Strictly preemptive & 1.58 & 3.534 & $5.130^{* *}$ & $4.185^{*}$ & $9.227 * * *$ & $23.61 * * *$ \\
& $(1.304)$ & $(2.787)$ & $(2.153)$ & $(2.324)$ & $(1.852)$ & $(3.680)$ \\
\hline$R$-squared & 0.116 & 0.174 & 0.206 & 0.198 & 0.184 & 0.268 \\
\# of countries & 110 & 110 & 110 & 109 & 109 & 109 \\
\# of observations & 2,936 & 2,912 & 2,790 & 2,674 & 2,559 & 2,542 \\
\hline
\end{tabular}

Notes: The table shows local projections (OLS) of the variables shown in each panel for $h=1,2, \ldots, 5$, where $h$ indicates horizon. All regressions include a constant term, lagged dependent variables (lag 1 and lag 2), cyclical component of log of GDP obtained from a Hodrick-Prescott filter with a smoothing parameter of 100 , and country fixed effects. Robust standard errors, clustered at the countrylevel, are in parentheses. ${ }^{* \star *},{ }^{* *}$, and ${ }^{*}$ indicate statistical significance at 1 percent, 5 percent, and 10 percent level, respectively. 
Figure E1: Local Projections with Expanded Sample, OLS
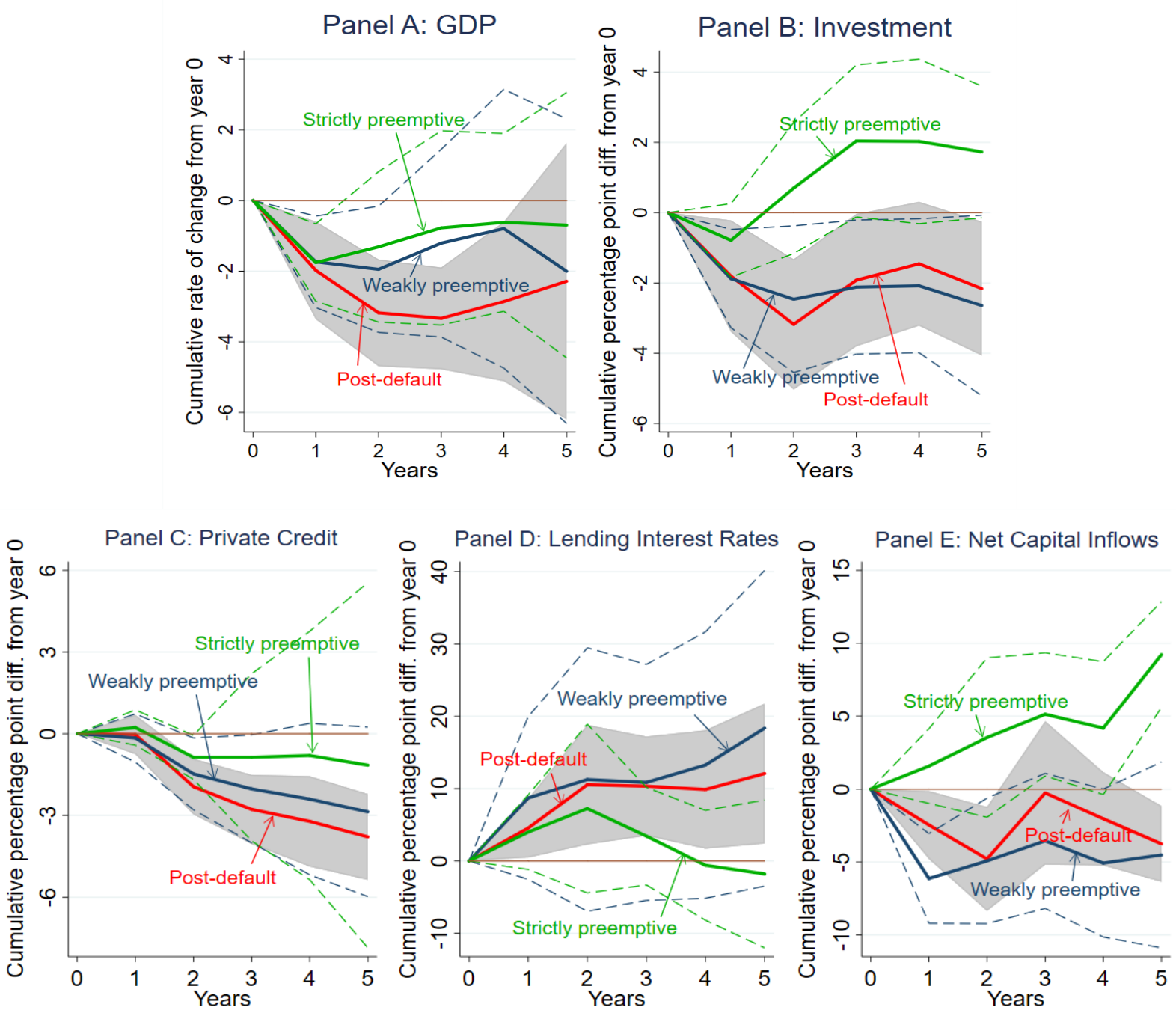

Notes: The figure shows local projections of the variables shown in each panel for $h=1,2, \ldots, 5$, where $h$ indicates horizon. Dependent variables are as follows. Panel A: $100 \times\left(G D P_{i, t+h}-G D P_{i, t}\right) / G D P_{i, t}$, Panel B: $100 \times\left(\right.$ Investment $_{i, t+h} / G D P_{i, t+h}-$ Investment $\left._{i, t} / G D P_{i, t}\right)$, Panel C: $100 \times\left(\right.$ Credit $_{i, t+h} / G D P_{i, t+h}-$ Credit $\left._{i, t} / G D P_{i, t}\right)$, Panel D: $100 \times\left(\right.$ LendingRate $_{i, t+h}-$ LendingRate $\left._{i, t}\right)$, and Panel E: $100 \times\left(N C I_{i, t+h} / G D P_{i, t+h}-N C I_{i, t} / G D P_{i, t}\right)$. Solid

lines in red, blue, and green are point estimates. Gray bands and dotted lines in blue and green are 95 percent confidence intervals. The sample period is 1970-2013.

\section{E.2. Standard Poor's Default Episodes}

Some studies on sovereign debt use S\&P default data, for instance Borensztein and Panizza (2009), Levy-Yeyati and Panizza (2011), or Kuvshinov and Zimmermann (2016). S\&P data do not differentiate restructuring strategies and cover only 88 "default" episodes in countries where ratings are assigned: (i) post-default restructurings and (ii) only exchange events - not duration from the start to the exchange - for preemptive restructurings. In this regard, the S\&P default sample is quite similar to those of post-default restructurings in our sample. Figure E3 reports the AIPW estimates-Figure E2 and Table E2 report the 1st-stage probit regression results - for GDP, investment, private credit, and net capital inflows in S\&P defaults. The results for GDP, investment, private credit, and net capital inflows in S\&P defaults (Panels A, B, C, and D in Figure E3) largely mirror those in post-default restructurings (Panels A, B, C, and E in Figure 7). 
Table E2: Predicting the Start of S\&P Defaults, Probit

\begin{tabular}{|c|c|c|c|}
\hline & $x 3$ & $x 2$ & $x 1$ \\
\hline \multirow[t]{2}{*}{ \# of past post-default } & $0.153^{*}$ & 0.282 & $1.765 * * *$ \\
\hline & $(0.085)$ & $(0.178)$ & $(0.549)$ \\
\hline \multirow[t]{2}{*}{ \# of past weakly preemptive } & 0.059 & $-0.659 * * *$ & -0.502 \\
\hline & $(0.121)$ & $(0.245)$ & $(0.433)$ \\
\hline \multirow[t]{2}{*}{ \# of past strictly preemptive } & -0.0978 & 0.419 & -8.958 \\
\hline & $(0.120)$ & $(0.516)$ & $(456.2)$ \\
\hline \multirow[t]{2}{*}{ \# of past banking crises } & $-0.148 * * *$ & $-0.130 *$ & -0.0914 \\
\hline & $(0.045)$ & $(0.071)$ & $(0.183)$ \\
\hline \multirow[t]{2}{*}{ External debt-to-GDP ratio, lag } & & $-1.052 * *$ & $-3.355 * *$ \\
\hline & & $(0.429)$ & $(1.589)$ \\
\hline \multirow[t]{2}{*}{ Interest payments-to-GDP ratio, lag } & & $20.02 * * *$ & 2.861 \\
\hline & & $(6.867)$ & $(18.56)$ \\
\hline \multirow[t]{2}{*}{ Change in credit ratings, lag } & & 0.015 & 0.054 \\
\hline & & $(0.031)$ & $(0.057)$ \\
\hline \multirow[t]{2}{*}{ Cyclical comp. of log of GDP per capita, lag } & & 3.320 & -2.817 \\
\hline & & $(2.114)$ & $(4.728)$ \\
\hline \multirow[t]{2}{*}{ GDP growth rate, lag } & & $-4.439 * *$ & $-10.99 * *$ \\
\hline & & $(2.051)$ & $(4.917)$ \\
\hline \multirow[t]{2}{*}{ Freedom index, civil liberty, lag } & & $0.190 *$ & 0.054 \\
\hline & & $(0.105)$ & $(0.289)$ \\
\hline \multirow[t]{2}{*}{ \# of years from the previous debt rest. } & & & $-0.256 * * *$ \\
\hline & & & $(0.079)$ \\
\hline \multirow[t]{2}{*}{ Legislative index of electoral comp., lag } & & & 0.239 \\
\hline & & & $(0.199)$ \\
\hline \multirow[t]{2}{*}{ Executive index of electoral comp., lag } & & & -0.099 \\
\hline & & & $(0.217)$ \\
\hline \multirow[t]{2}{*}{ Coerciveness index, lag } & & & $-0.317 * *$ \\
\hline & & & $(0.133)$ \\
\hline Country fixed effects & Yes & Yes & Yes \\
\hline \# of observations & 2,068 & 815 & 415 \\
\hline \# of countries & 74 & 39 & 39 \\
\hline \# of S\&P default episodes & 46 & 29 & 25 \\
\hline Likelihood ratio & 34.53 & 59.59 & 91.03 \\
\hline ( $p$-value $)$ & 0.953 & 0.014 & 0.000 \\
\hline Pseudo $R$-squared & 0.054 & 0.190 & 0.529 \\
\hline ROC & 0.70 & 0.87 & 0.96 \\
\hline
\end{tabular}

Notes: All regressions include country fixed effects. The sample period is $1970-2013 .{ }^{* * *}$, **, and * indicate statistical significance at 1 percent, 5 percent, and 10 percent level, respectively. Standard errors are in parentheses. 
Figure E2: First-Stage Estimation for AIPW, S\&P Defaults
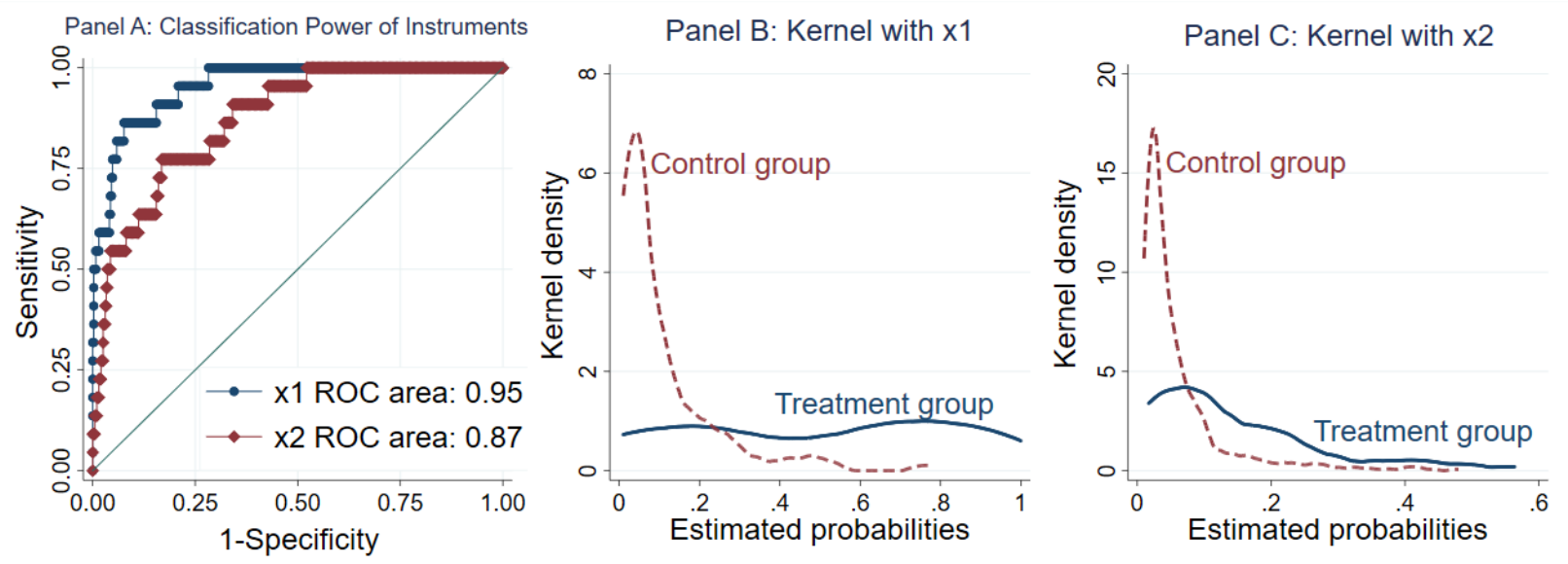

Notes: The figure shows effectiveness of instruments used to estimate the first-stage probit model.

Figure E3: S\&P Defaults, AIPW
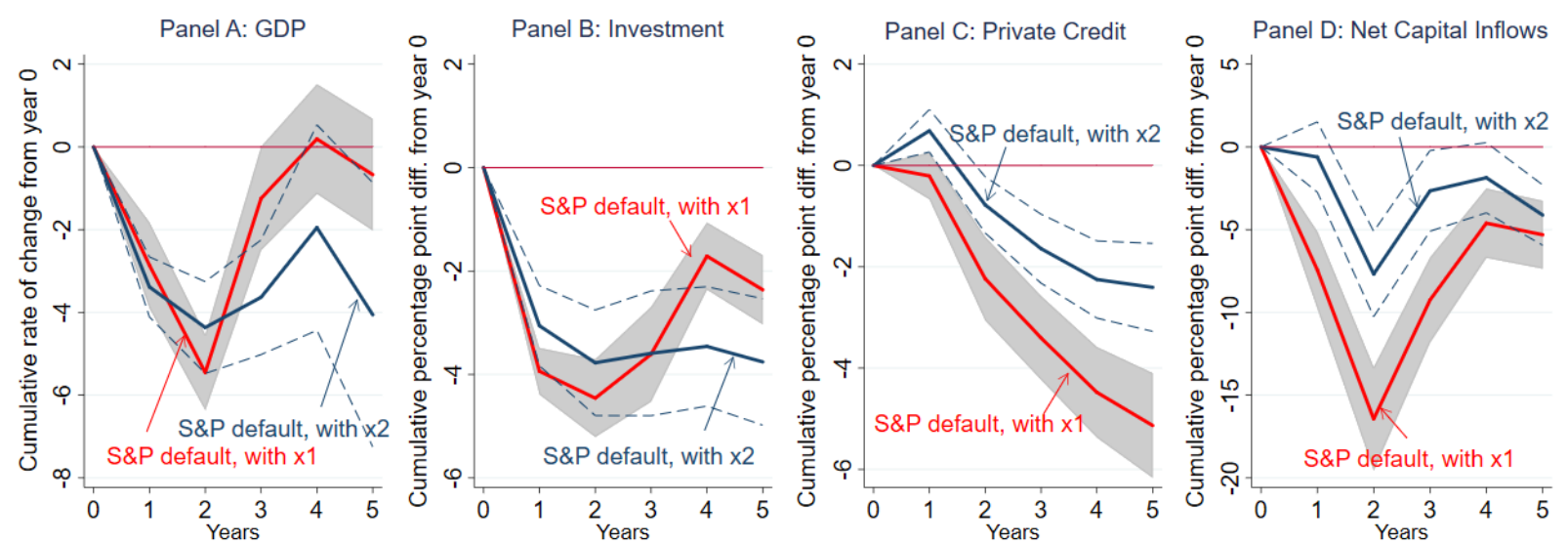

Notes: The figure shows local projections of the variables shown in each panel for $h=1,2, \ldots, 5$, where $h$ indicates horizon. Red and blue solid lines are point estimates for S\&P default episodes. Gray bands and blue dotted lines indicate 95 percent confidence intervals. The sample period is 1970-2013. 
Table E3: Estimation Results, S\&P Defaults, AIPW

\begin{tabular}{|c|c|c|c|c|c|c|}
\hline & $h=1$ & $h=2$ & $h=3$ & $h=4$ & $h=5$ & Sum \\
\hline \multirow[t]{2}{*}{ S\&P default, with $x 1$} & $-2.859 * * *$ & $-5.453 * * *$ & $-1.244 *$ & 0.192 & -0.670 & $-9.216^{* * *}$ \\
\hline & $(0.530)$ & $(0.467)$ & $(0.639)$ & $(0.677)$ & $(0.689)$ & $(2.359)$ \\
\hline \# of obs. & 372 & 372 & 372 & 372 & 359 & 359 \\
\hline \# of countries & 16 & 16 & 16 & 16 & 16 & 16 \\
\hline \# of S\&P defaults & 21 & 21 & 21 & 21 & 21 & 21 \\
\hline \multirow[t]{2}{*}{ S\&P default, with $x 2$} & $-3.383 * * *$ & $-4.366 * * *$ & $-3.634 * * *$ & -1.950 & $-4.057 * *$ & $-16.68 * * *$ \\
\hline & $(0.370)$ & $(0.566)$ & $(0.707)$ & $(1.267)$ & $(1.629)$ & $(4.029)$ \\
\hline \# of obs. & 786 & 786 & 786 & 786 & 758 & 758 \\
\hline \# of countries & 28 & 28 & 28 & 28 & 28 & 28 \\
\hline \# of S\&P defaults & 38 & 38 & 38 & 38 & 38 & 38 \\
\hline \multicolumn{7}{|c|}{ Panel B: Dep. Var. $=100 \times\left(\right.$ Investment $_{i, t+h} / G D P_{i, t+h}-$ Investment $\left._{i, t} / G D P_{i, t}\right)$} \\
\hline & $h=1$ & $h=2$ & $h=3$ & $h=4$ & $h=5$ & Sum \\
\hline \multirow[t]{2}{*}{ S\&P default, with $x 1$} & $-3.937 * * *$ & $-4.459 * * *$ & $-3.610 * * *$ & $-1.711 * * *$ & $-2.362 * * *$ & $-15.65 * * *$ \\
\hline & $(0.230)$ & $(0.384)$ & $(0.468)$ & $(0.332)$ & $(0.342)$ & $(1.423)$ \\
\hline \# of obs. & 372 & 372 & 372 & 372 & 359 & 359 \\
\hline \# of countries & 16 & 16 & 16 & 16 & 16 & 16 \\
\hline \# of S\&P defaults & 21 & 21 & 21 & 21 & 21 & 21 \\
\hline \multirow[t]{2}{*}{ S\&P default, with $x 2$} & $-3.057 * * *$ & $-3.774 * * *$ & $-3.591 * * *$ & $-3.458 * * *$ & $-3.757 * * *$ & $-17.31 * * *$ \\
\hline & $(0.395)$ & $(0.521)$ & $(0.615)$ & $(0.589)$ & $(0.624)$ & $(2.555)$ \\
\hline \# of obs. & 740 & 740 & 740 & 740 & 713 & 713 \\
\hline \# of countries & 27 & 27 & 27 & 27 & 27 & 27 \\
\hline \# of S\&P defaults & 35 & 35 & 35 & 35 & 35 & 35 \\
\hline \multicolumn{7}{|c|}{ Panel C: Dep. Var. $=100 \times\left(\right.$ Credit $_{i, t+h} / G D P_{i, t+h}-$ Credit $\left._{i, t} / G D P_{i, t}\right)$} \\
\hline & $h=1$ & $h=2$ & $h=3$ & $h=4$ & $h=5$ & Sum \\
\hline \multirow[t]{2}{*}{ S\&P default, with $x 1$} & $-0.206^{* * *}$ & $-2.236 * * *$ & $-3.404 * * *$ & $-4.478 * * *$ & $-5.133 * * *$ & $-15.37 * * *$ \\
\hline & $(0.236)$ & $(0.421)$ & $(0.422)$ & $(0.457)$ & $(0.528)$ & $(1.875)$ \\
\hline \# of obs. & 369 & 369 & 369 & 369 & 356 & 356 \\
\hline \# of countries & 16 & 16 & 16 & 16 & 16 & 16 \\
\hline \# of S\&P defaults & 20 & 20 & 20 & 20 & 20 & 20 \\
\hline \multirow[t]{2}{*}{ S\&P default, with $x 2$} & $0.686^{* * *}$ & $-0.778 * * *$ & $-1.642 * * *$ & $-2.251 * * *$ & $-2.407^{* * *}$ & $-6.474 * * *$ \\
\hline & $(0.214)$ & $(0.283)$ & $(0.348)$ & $(0.388)$ & $(0.443)$ & (1.489) \\
\hline \# of obs. & 759 & 758 & 757 & 757 & 730 & 722 \\
\hline \# of countries & 28 & 28 & 28 & 28 & 28 & 28 \\
\hline \# of S\&P defaults & 36 & 35 & 35 & 35 & 35 & 35 \\
\hline \multicolumn{7}{|c|}{ Panel D: Dep. Var. $=100 \times\left(N C I_{i, t+h} / G D P_{i, t+h}-N C I_{i, t} / G D P_{i, t}\right)$} \\
\hline & $h=1$ & $h=2$ & $h=3$ & $h=4$ & $h=5$ & Sum \\
\hline \multirow[t]{2}{*}{ S\&P default, with $x 1$} & $-7.432 * * *$ & $-16.44^{* * *}$ & $-9.251 * * *$ & $-4.606^{* * *}$ & $-5.307 * * *$ & $-15.37 * * *$ \\
\hline & $(1.190)$ & $(1.598)$ & $(1.314)$ & $(1.071)$ & $(1.047)$ & $(1.875)$ \\
\hline \# of obs. & 367 & 366 & 366 & 366 & 353 & 356 \\
\hline \# of countries & 16 & 16 & 16 & 16 & 16 & 16 \\
\hline \# of S\&P defaults & 21 & 21 & 21 & 21 & 21 & 20 \\
\hline \multirow[t]{2}{*}{ S\&P default, with $x 2$} & -0.610 & $-7.680^{* * *}$ & $-2.656^{* *}$ & $-1.861^{*}$ & $-4.117 * * *$ & $-6.474 * * *$ \\
\hline & (1.084) & $(1.313)$ & $(1.243)$ & $(1.082)$ & $(0.931)$ & (1.489) \\
\hline \# of obs. & 756 & 751 & 747 & 743 & 713 & 722 \\
\hline \# of countries & 28 & 28 & 28 & 28 & 28 & 28 \\
\hline \# of S\&P defaults & 38 & 38 & 38 & 38 & 38 & 35 \\
\hline
\end{tabular}

Notes: All regressions include a constant term, the lagged dependent variable, cyclical component of log of GDP obtained from a HodrickPrescott filter with a smoothing parameter of 100 , and country fixed effects. 


\section{E.3. Restructurings with IMF-supported Programs and Paris Club Restructurings}

Next, we check how the GDP and investment respond under the three different restructuring strategies once we take into account whether the country has an IMF-supported program or an official debt (Paris Club) restructuring. Under an IMF-supported program or an official debt restructuring, the availability of official (multilateral or bilateral) financing with official debt being restructured through Paris Club deals can mitigate some of the adverse effects on GDP and investment (through a capital inflow-credit-investment channel).

We apply panel OLS regression to capture the influence of an IMF-supported program or an official debt restructuring occurred over the forecast horizon. Figure E4 reports the panel OLS estimates for GDP and investment for the three restructuring strategies with and without IMFsupported programs or Paris Club restructurings. Declines in GDP and investment following a post-default restructuring or a weakly preemptive restructuring are significantly moderated by official financing or official debt treatment (Left and Center in Panels A and B).

Figure E4: Private External Debt Restructurings with/without IMF-Supported Programs or Paris Club Restructurings, Panel OLS

Panel A: GDP
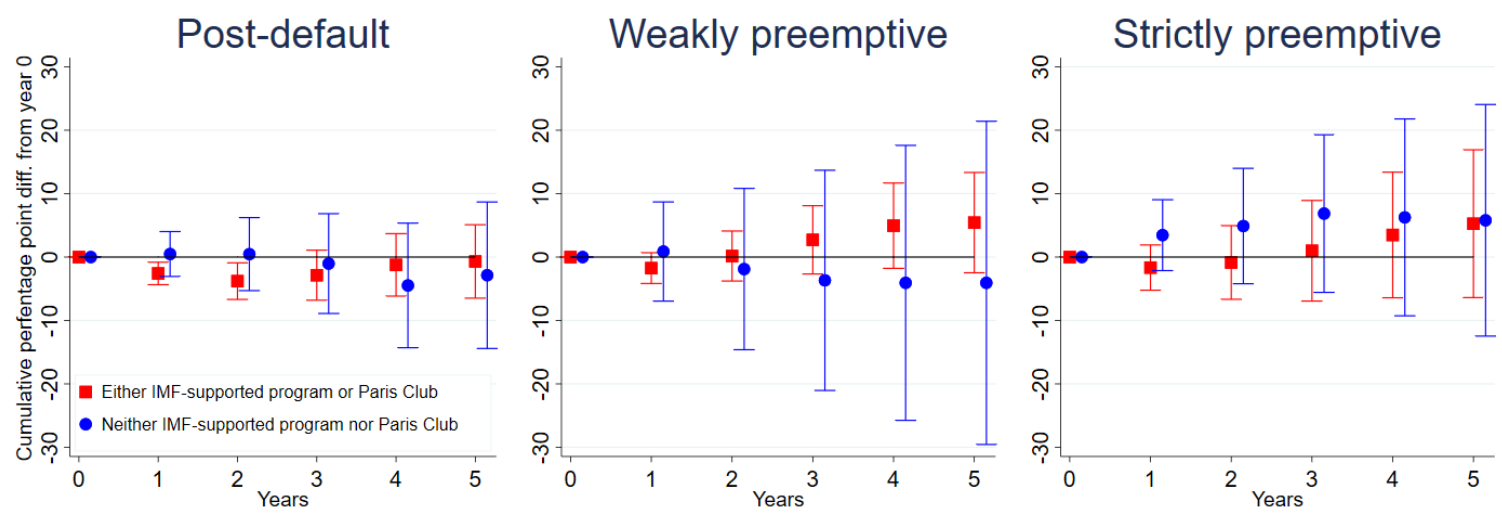

Panel B: Investment
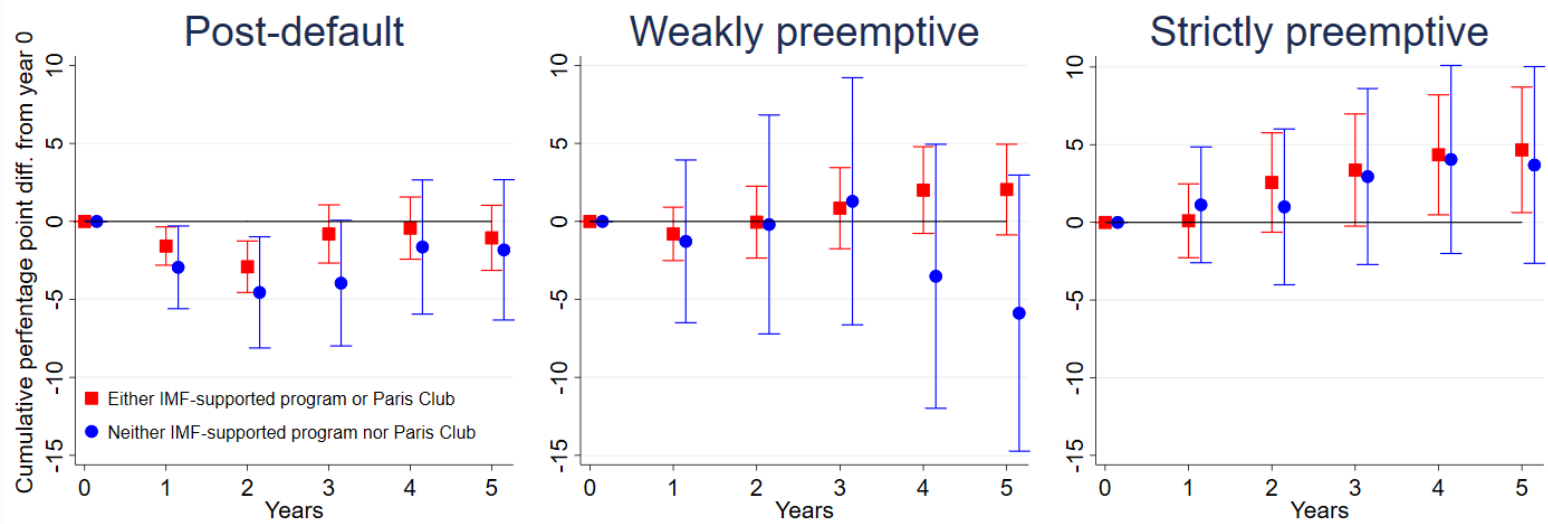

Notes: The figure shows panel OLS regressions of the variables shown in each panel for $h=1,2, \ldots, 5$, where $h$ indicates horizon. Square dots in red and circle dots in blue are point estimates for private debt restructurings with and without IMF-supported programs or official (Paris Club) debt restructurings. Upper and lower limits of lines in red and blue indicate 95 percent confidence intervals. The sample period is 1970-2013. 


\section{E.4. "Single" External Debt Restructurings}

In this sub-section, we consider whether large costs in restructurings (in particular post-default cases) are driven solely by external debt restructurings or also by associated domestic debt restructurings. Asonuma and Papaioannou (2016) provide domestic debt restructuring dataset based on both jurisdiction and creditor residence criterion - an alternative is based on currency denomination criteria for instance Reinhart and Rogoff (2011a), S\&P (2006) — which are consistent with jurisdiction and creditor residence criterion used to define external debt restructurings in Cruces and Trebesch (2013) and Asonuma and Trebesch (2016). We combine the data on domestic debt restructurings on our external debt restructuring dataset and define a "single" external debt restructuring if no domestic debt restructuring occurs during duration of an external debt restructuring and a "dual" domestic-external debt restructuring if otherwise.

Table E4: External Debt Restructurings with/without Domestic Debt Restructurings

\begin{tabular}{|c|c|c|c|c|}
\hline & All & Post-default & $\begin{array}{c}\text { Weakly } \\
\text { preemptive }\end{array}$ & $\begin{array}{c}\text { Strictly } \\
\text { preemptive }\end{array}$ \\
\hline Debt Restructuring Episodes & 179 & 111 & 45 & 23 \\
\hline $\begin{array}{l}\text { "Single" External Debt Restructurings } \\
\text { (No domestic debt restructuring occurs within } \\
\text { duration of external debt restructurings) }\end{array}$ & 156 & 95 & 41 & 20 \\
\hline Share of Single External Debt Restructurings & $87 \%$ & $86 \%$ & $91 \%$ & $87 \%$ \\
\hline
\end{tabular}

Figure E5 and Table E5 reports AIPW estimates for the effect on GDP, investment, private credit, and net capital inflows during post-default and weakly preemptive restructurings. We follow the same presentation as in Figure 7. The solid lines in red and the gray bands indicate the point estimates and 95 percent confidence intervals for all external debt restructurings, respectively. The solid and dotted lines in blue indicate the point estimates and 95 percent confidence intervals for single external debt restructurings, respectively.

All Panels A, B, C, and D in Parts I and II show that estimated impacts on GDP, investment, private credit, and net capital inflows in the sample of all external debt restructurings (both postdefault and weakly preemptive cases) are quite similar to (to large extent overlapping with) those of restructuring only external debt. This is consistent with the large sample of single external debt restructurings in total external debt restructuring episodes ( 87 percent). Clearly, large costs in restructurings are dominantly associated with restructuring only on external debt. 
Figure E5: "Single" External Debt Restructurings, AIPW

Part I: Post-default Restructurings
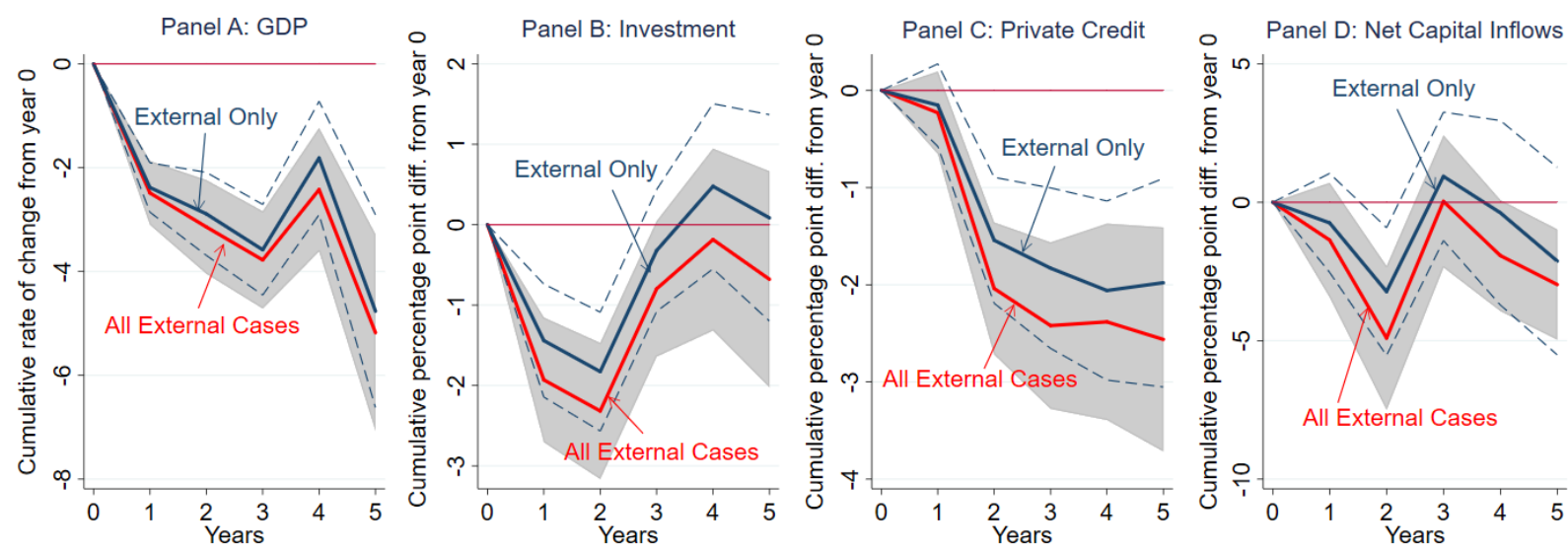

Part II: Weakly Preemptive Restructurings
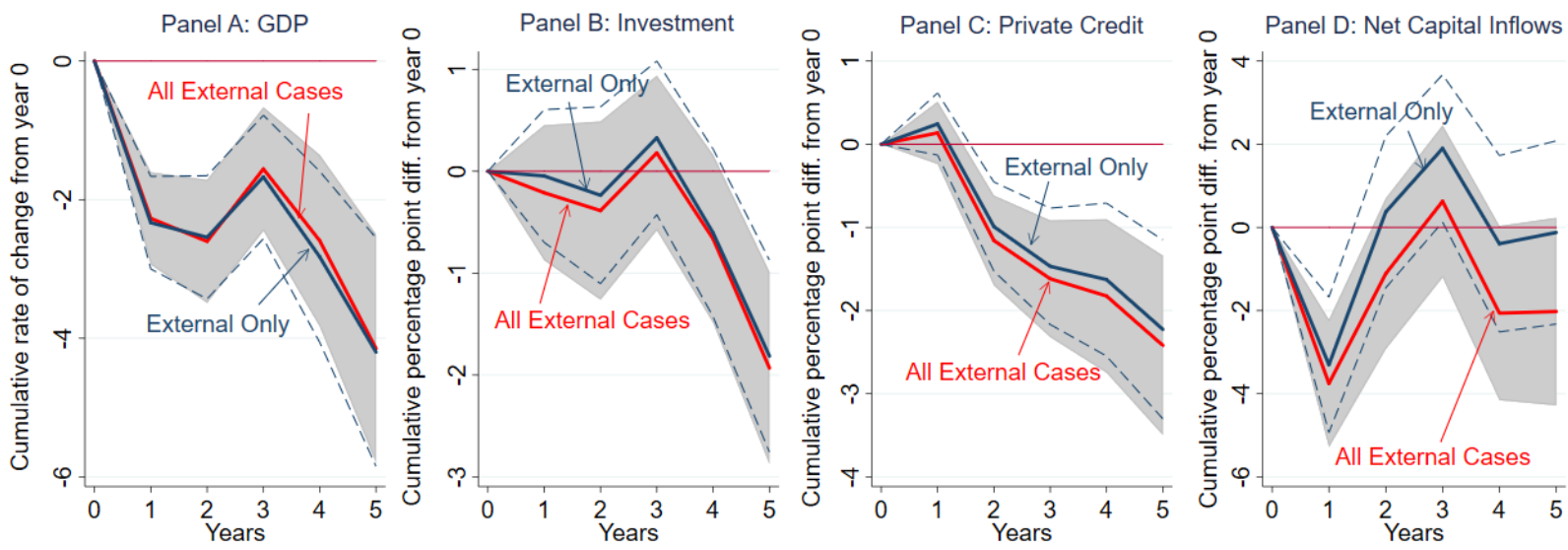

Notes: Solid lines in red and blue are point estimates. Gray bands and dotted lines in blue are 95 percent confidence intervals The sample period is 1970-2013. 
Table E5: Estimation Results, Single External Debt Restructurings, AIPW

\begin{tabular}{rcccccc}
\multicolumn{6}{c}{ Panel A: Dep. Var. $=100 \times\left(G D P_{i, t+h}-G D P_{i, t}\right) / G D P_{i, t}$} \\
\hline & $h=1$ & $h=2$ & $h=3$ & $h=4$ & $h=5$ & Sum \\
\hline Post-default & $-2.381^{* * *}$ & $-2.889^{* * *}$ & $-3.581^{* * *}$ & $-1.813^{* * *}$ & $-4.763^{* * *}$ & $-14.70^{* * *}$ \\
& $(0.242)$ & $(0.408)$ & $(0.446)$ & $(0.557)$ & $(0.947)$ & $(2.079)$ \\
\# of obs. & 825 & 825 & 825 & 825 & 796 & 796 \\
\# of countries & 29 & 29 & 29 & 29 & 29 & 29 \\
\# of debt restructuring obs. & 33 & 33 & 33 & 33 & 33 & 33 \\
\hline Weakly preemptive & $-2.332^{* * *}$ & $-2.543^{* * *}$ & $-1.673^{* * *}$ & $-2.824 * * *$ & $-4.199^{* * *}$ & $-13.21^{* * *}$ \\
& $(0.340)$ & $(0.453)$ & $(0.454)$ & $(0.629)$ & $(0.841)$ & $(2.114)$ \\
\# of obs. & 371 & 371 & 371 & 371 & 357 & 357 \\
\# of countries & 14 & 14 & 14 & 14 & 14 & 14 \\
\# of debt restructuring obs. & 20 & 20 & 20 & 20 & 20 & 20 \\
\hline
\end{tabular}

Panel B: Dep. Var. $=100 \times\left(\right.$ Investment $_{i, t+h} / G D P_{i, t+h}-$ Investment $\left._{i, t} / G D P_{i, t}\right)$

\begin{tabular}{rcccccc}
\hline & $h=1$ & $h=2$ & $h=3$ & $h=4$ & $h=5$ & Sum \\
\hline Post-default & $-1.441^{* * *}$ & $-1.828^{* * *}$ & -0.322 & 0.477 & 0.085 & -2.884 \\
& $(0.358)$ & $(0.377)$ & $(0.387)$ & $(0.524)$ & $(0.655)$ & $(2.089)$ \\
\# of obs. & 737 & 737 & 737 & 737 & 711 & 711 \\
\# of countries & 26 & 26 & 26 & 26 & 26 & 26 \\
\# of debt restructuring obs. & 29 & 29 & 29 & 29 & 29 & 29 \\
\hline Weakly preemptive & -0.046 & -0.235 & 0.328 & -0.605 & $-1.813 * * *$ & -2.062 \\
& $(0.333)$ & $(0.442)$ & $(0.385)$ & $(0.420)$ & $(0.481)$ & $(1.797)$ \\
\# of obs. & 343 & 343 & 343 & 343 & 330 & 330 \\
\# of countries & 13 & 13 & 13 & 13 & 13 & 13 \\
\# of debt restructuring obs. & 19 & 19 & 19 & 19 & 19 & 19 \\
\hline
\end{tabular}

\begin{tabular}{rcccccc}
\multicolumn{6}{c}{ Panel C: Dep. Var. $=100 \times$ Credit $_{i, t+h} / G D P_{i, t+h}-$ Credit $\left._{i, t} / G D P_{i, t}\right)$} \\
\hline & $h=1$ & $h=2$ & $h=3$ & $h=4$ & $h=5$ & Sum \\
\hline Post-default & -0.151 & $-1.542^{* * *}$ & $-1.829^{* * *}$ & $-2.060^{* * *}$ & $-1.979^{* * *}$ & $-7.804^{* * *}$ \\
& $(0.217)$ & $(0.330)$ & $(0.421)$ & $(0.470)$ & $(0.548)$ & $(1.812)$ \\
\# of obs. & 752 & 750 & 748 & 747 & 720 & 716 \\
\# of countries & 27 & 27 & 27 & 27 & 27 & 27 \\
\# of debt restructuring obs. & 30 & 29 & 29 & 29 & 29 & 29 \\
\hline Weakly preemptive & 0.244 & $-0.990^{* * *}$ & $-1.468^{* * *}$ & $-1.627^{* * *}$ & $-2.225^{* * *}$ & $-6.590^{* * *}$ \\
& $(0.190)$ & $(0.273)$ & $(0.357)$ & $(0.469)$ & $(0.548)$ & $(1.580)$ \\
\# of obs. & 371 & 371 & 371 & 371 & 357 & 357 \\
\# of countries & 14 & 14 & 14 & 14 & 14 & 14 \\
\# of debt restructuring obs. & 20 & 20 & 20 & 20 & 20 & 20 \\
\hline
\end{tabular}

\begin{tabular}{rcccccc}
\hline \multicolumn{7}{c}{ Panel D: Dep. Var. $=100 \times\left(N C I_{i, t+h} / G D P_{i, t+h}-N C I_{i, t} / G D P_{i, t}\right)$} \\
\hline & $h=1$ & $h=2$ & $h=3$ & $h=4$ & $h=5$ & Sum \\
\hline Post-default & -0.745 & $-3.225^{* * *}$ & 0.937 & -0.379 & -2.123 & $-7.088^{* * *}$ \\
& $(0.912)$ & $(1.177)$ & $(1.183)$ & $(1.699)$ & $(1.728)$ & $(2.015)$ \\
\# of obs. & 764 & 757 & 751 & 746 & 716 & 730 \\
\# of countries & 29 & 29 & 29 & 29 & 29 & 29 \\
\# of debt restructuring obs. & 33 & 33 & 33 & 33 & 32 & 29 \\
\hline Weakly preemptive & $-3.303^{* * *}$ & 0.372 & $1.899^{* *}$ & -0.393 & -0.121 & $-5.635^{* * *}$ \\
& $(0.830)$ & $(0.930)$ & $(0.904)$ & $(1.082)$ & $(1.124)$ & $(1.561)$ \\
\# of obs. & 360 & 358 & 357 & 357 & 343 & 348 \\
\# of countries & 14 & 14 & 14 & 14 & 14 & 14 \\
\# of debt restructuring obs. & 20 & 20 & 20 & 20 & 20 & 20 \\
\hline
\end{tabular}

Notes: All regressions include a constant term, the lagged dependent variable, cyclical component of log of GDP obtained from a Hodrick-Prescott filter with a smoothing parameter of 100 , and country fixed effects. 


\section{E.5. Non-overlapping and Sequential Restructurings}

To address concerns on influence by restructurings where duration overlaps, we consider the following three alternative classifications of restructurings: (1) individual restructurings without overlapping years - if there are a multiple of restructurings where duration overlaps, we treat duration of the previous restructurings as one ending at year before the next restructuring starts and duration of the next restructurings as it is defined; (2) sequential restructurings with the initial strategy - if there are a multiple of restructurings with different strategies where duration overlaps, we consider as one "sequential restructuring" with the strategy of the initial individual restructurings - ; and (3) sequential restructurings with the worst strategy - similarly, we consider as one "sequential restructuring" with the worst strategy among individual strategies of overlapping restructurings. For example, if there is a weakly preemptive restructuring followed by a post-default restructuring, the sequential event would be coded as a weakly preemptive restructuring under the second classification (2) and as a post-default restructuring under the third classification (3).

Figure E6 reports the AIPW estimates for GDP in individual restructurings without overlapping years and in sequential restructuring with the initial and worst strategy, respectively. Under the alternative classifications of restructurings, GDP experiences a similar dynamic after each type of restructurings. The results show that our baseline AIPW estimates are robust (as reported in Figure 7). 
Figure E6: Alternative Classifications of Restructurings, AIPW

Part I: GDP under Individual Restructurings without Overlapping Years Post-default

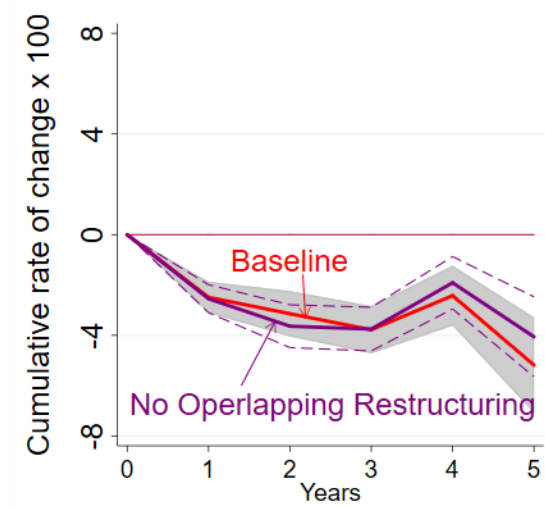

Weakly preemptive
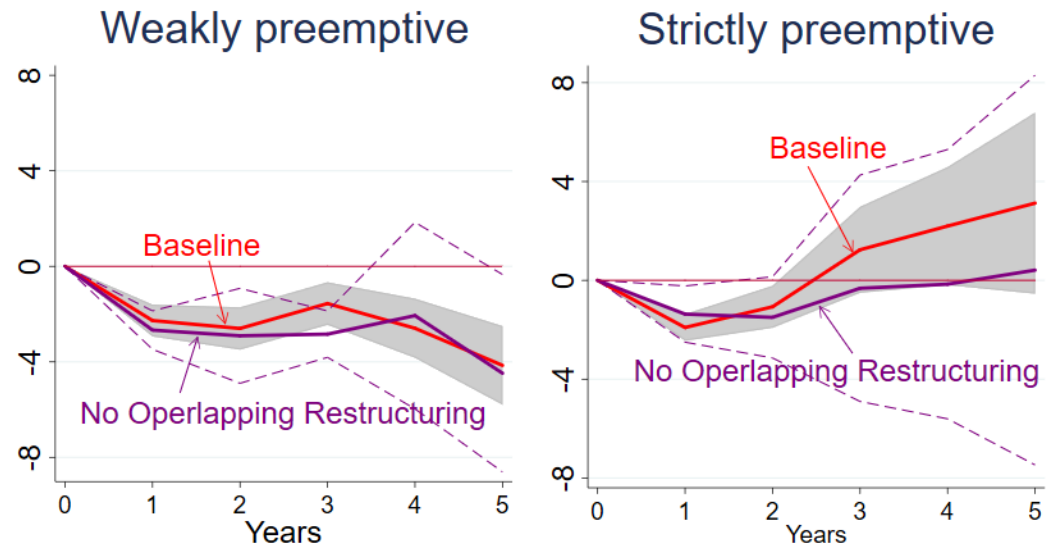

Part II: GDP under Individual Restructurings with the Initial Strategy
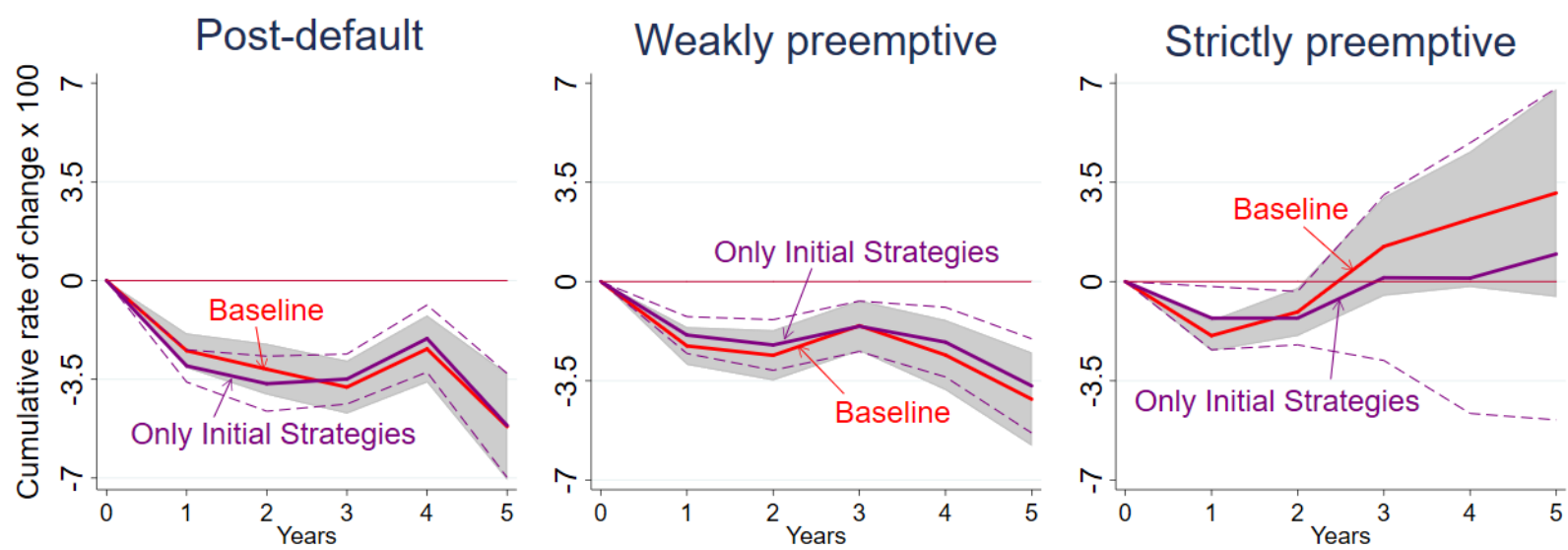

Part III: GDP under Individual Restructurings with the Worst Strategy
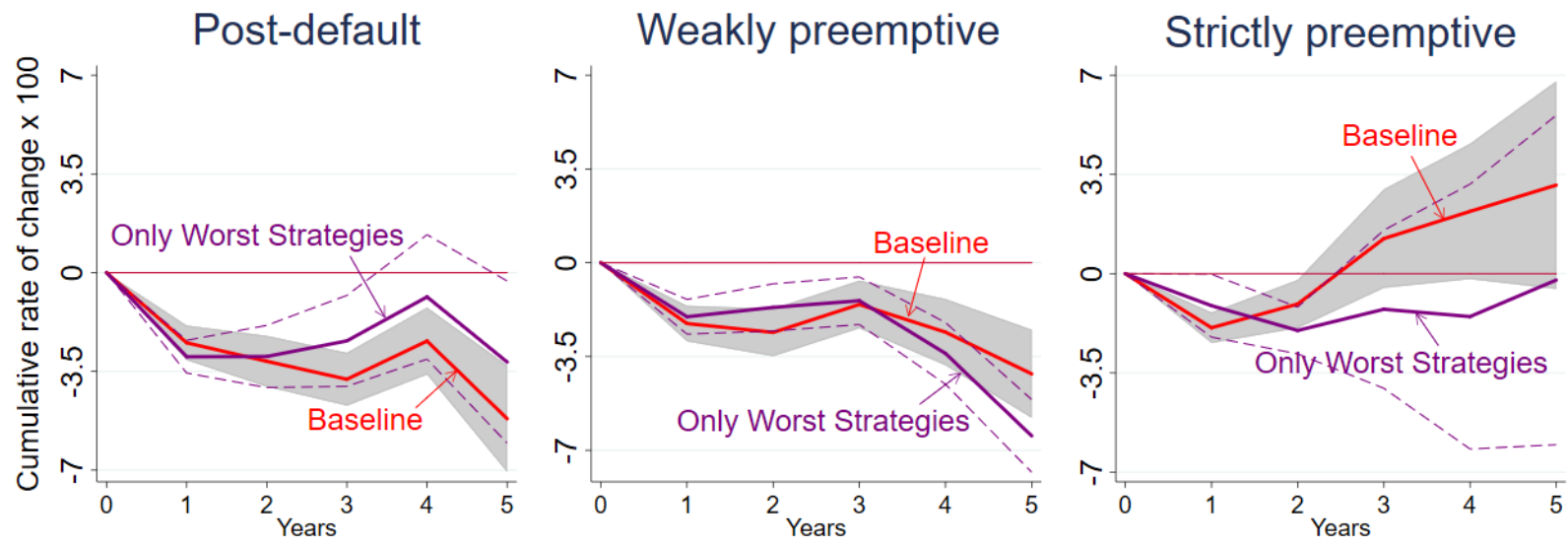

Notes: The figure shows local projections of the variables shown in each panel for $h=1,2, \ldots, 5$, where $h$ indicates horizon. Solid lines in red and purple are point estimates. Bands and dotted lines in purple are 95 percent confidence intervals. The sample period is $1970-$ 2013. 


\section{E.6. Enlarged Set of Instruments for AIPW Estimation}

One might have further concerns on influence by domestic political system, banking sector, past banking crises, government behavior, and even more how GDP growth is predicted before the debt crisis. To address these concerns, we conduct two robustness checks.

First, we apply the AIPW estimation with the augmented set of instruments including our baseline (selected) instruments: (i) years since the last restructurings (for any types of debt restructurings), (ii) legislative and executive indices of electoral competitiveness (LIEC and EIEC come from the Database of Political Institutions), and (iii) government coerciveness indicator during past restructurings (Enderlein et al., 2012).

LIEC is constructed as follows: 1 if there is no legislature; 2 if unelected legislature; 3 if elected from one candidate; 4 if 1 party, multiple candidates; 5 if multiple parties are legal but only one party won seats; 6 if multiple parties win seats but the largest party received more than 75 percent of the seats; 7 if the largest party got less than 75 percent. EIEC is constructed as follows: 1 if rival chief executives in one country, particularly in the setting of armed conflicts, are counted as no executives; 2 if executives elected by small appointed juntas or by appointed electoral colleges; 3 if the chief executives of communist nations (the chairman of the Communist Party); 6 or 7 if competitively elected prime ministers.

Figure E7: Classification Power of the First Stage Regressors with Enlarged Set of Instruments
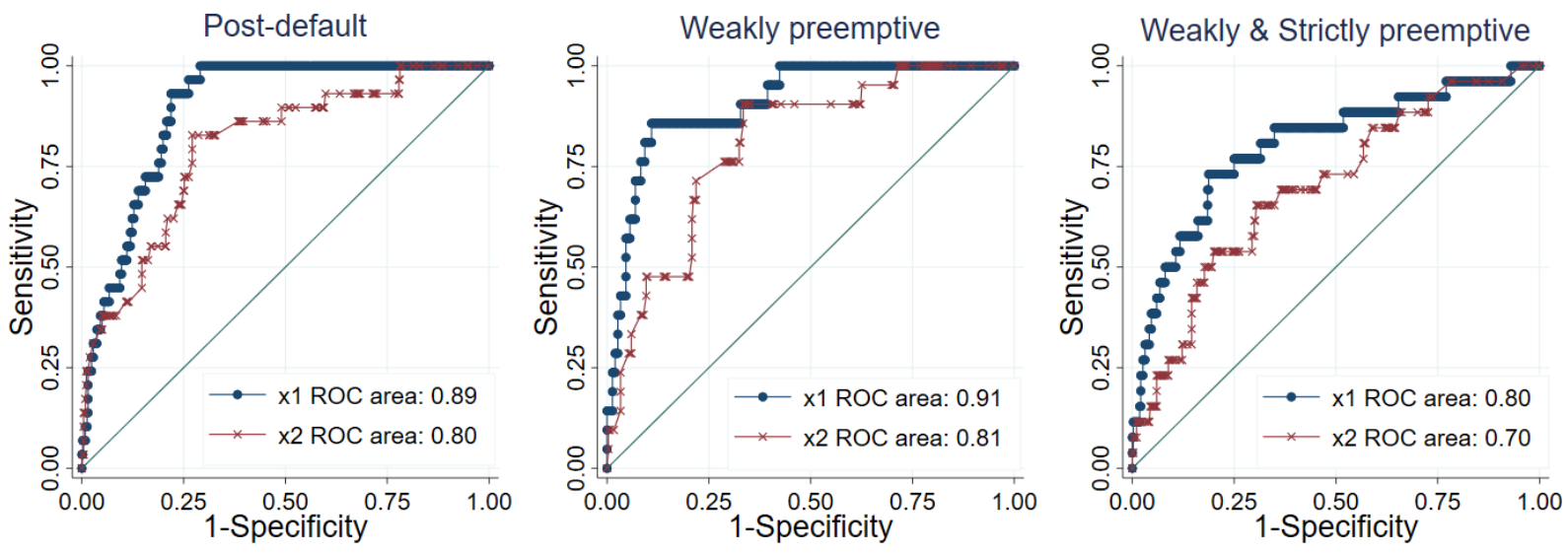

\footnotetext{
The figure shows the area under the ROC curve. The ROC area takes a value between 0.50 and 1 . Taking a value of 0.50 indicates that regressors have no classification power when they classify observations into those from the start of debt restructurings and non-restructuring observations. Taking a value of 1 indicating that regressors have the perfect classification power. $x 1$ denotes the set of instruments used in the baseline estimation and $x 2$ includes additional instruments in addition to the baseline instruments.
}

We are unable to run logit estimation for strictly preemptive case because the log likelihood function becomes non-concave largely due to limited observations. Therefore, we take the dummy variable taking one if there is either a weakly or strictly preemptive debt restructuring as the dependent variable in columns (5) and (6). ROC suggests that a greater number of instruments improves instruments' classification power when instruments classify observations into the treatment and control groups. ROC increases from 0.870 to 0.963 for the post-default 
case, from 0.953 to 0.993 for the weakly preemptive case, from 0.911 to 0.949 for the "weakly and strictly" preemptive case, respectively. These improvements are shown in Figure E7. In each panel, two sensitivity curves are reported. The one is for a set of instruments $x 1$, which is the set of instruments used in our baseline estimation. The other curve is for another set of instruments $x 2$, which is the set of baseline instruments plus additional instruments. All of the three panels show that the additional instruments improve the clarification power at the first stage. In contrast, however, a disadvantage of the enlarged set of instruments is a reduced number of restructuring observations as reported in Table E6. Samples of restructurings covered in this robustness analysis are substantially smaller than those in our baseline: 51 and 29 episodes for post-default and weakly preemptive cases in our baseline vs 25 and 21 episodes in the robustness analysis.

\section{Table E6: Predicting the Start of Debt Restructurings with Additional Instruments, Probit}

Dep. Var. = Dummy Variable Taking 1 at the Start of Debt Restructurings

\begin{tabular}{|c|c|c|c|c|c|c|}
\hline & \multicolumn{2}{|c|}{ Post-default } & \multicolumn{2}{|c|}{ Weakly preemptive } & \multicolumn{2}{|c|}{ Strictly preemptive } \\
\hline & $(1)$ & $(2)$ & $(3)$ & $(4)$ & $(5)$ & $(6)$ \\
\hline$\#$ of past post-default & $\begin{array}{l}0.755 * * * \\
(0.182)\end{array}$ & $\begin{array}{l}1.818 * * * \\
(0.439)\end{array}$ & $\begin{array}{l}-1.557 * * \\
(0.608)\end{array}$ & $\begin{array}{l}-7.329 \\
(6659)\end{array}$ & $\begin{array}{l}-0.619 * \\
(0.358)\end{array}$ & $\begin{array}{l}-1.246^{*} \\
(0.732)\end{array}$ \\
\hline \# of past weakly preemptive & $\begin{array}{c}0.101 \\
(0.268)\end{array}$ & $\begin{array}{c}0.582 \\
(0.432)\end{array}$ & $\begin{array}{l}0.502 * \\
(0.263)\end{array}$ & $\begin{array}{l}5.418 * * * \\
(1.724)\end{array}$ & $\begin{array}{c}0.067 \\
(0.221)\end{array}$ & $\begin{array}{l}-0.356 \\
(0.311)\end{array}$ \\
\hline \# of past strictly preemptive & $\begin{array}{l}-0.593 \\
(0.605)\end{array}$ & $\begin{array}{l}-10.21 \\
(802.3)\end{array}$ & $\begin{array}{l}-1.474 * \\
(0.800)\end{array}$ & $\begin{array}{l}-2.679 \\
(2.528)\end{array}$ & $\begin{array}{c}0.585 \\
(0.448)\end{array}$ & $\begin{array}{l}1.465^{*} \\
(0.860)\end{array}$ \\
\hline \# of past banking crises & $\begin{array}{c}-0.376^{* * *} \\
(0.084)\end{array}$ & $\begin{array}{l}-0.255 \\
(0.172)\end{array}$ & $\begin{array}{l}-0.319 \\
(0.195)\end{array}$ & $\begin{array}{c}0.036 \\
(0.699)\end{array}$ & $\begin{array}{l}-0.241^{*} \\
(0.142)\end{array}$ & $\begin{array}{l}-0.281 \\
(0.281)\end{array}$ \\
\hline External debt-to-GDP ratio, lag & $\begin{array}{c}-0.926 * * \\
(0.416)\end{array}$ & $\begin{array}{l}-5.312 * * * \\
(1.734)\end{array}$ & $\begin{array}{c}0.715 \\
(1.386)\end{array}$ & $\begin{array}{l}9.239^{*} \\
(4.824)\end{array}$ & $\begin{array}{l}-1.069 \\
(1.097)\end{array}$ & $\begin{array}{c}0.368 \\
(1.763)\end{array}$ \\
\hline Total interest payments-to-GDP ratiom lag & $\begin{array}{l}17.53 * * * \\
(6.216)\end{array}$ & $\begin{array}{c}40.17 * * * \\
(13.02)\end{array}$ & $\begin{array}{c}51.33^{* * *} \\
(17.68)\end{array}$ & $\begin{array}{l}-112.1 \\
(80.37)\end{array}$ & $\begin{array}{c}40.18 * * * \\
(14.27)\end{array}$ & $\begin{array}{c}26.27 \\
(21.86)\end{array}$ \\
\hline Change in credit ratings, lag & $\begin{array}{l}-0.018 \\
(0.031)\end{array}$ & $\begin{array}{c}0.016 \\
(0.052)\end{array}$ & $\begin{array}{c}0.004 \\
(0.039)\end{array}$ & $\begin{array}{l}0.200^{*} \\
(0.109)\end{array}$ & $\begin{array}{l}-0.011 \\
(0.033)\end{array}$ & $\begin{array}{c}0.011 \\
(0.040)\end{array}$ \\
\hline Cyclical comp. of log of GDP per capita, lag & $\begin{array}{c}1.591 \\
(2.059)\end{array}$ & $\begin{array}{l}-4.777 \\
(4.095)\end{array}$ & $\begin{array}{l}-5.401 \\
(3.319)\end{array}$ & $\begin{array}{c}23.54^{*} \\
(12.460)\end{array}$ & $\begin{array}{l}-4.382 \\
(2.676)\end{array}$ & $\begin{array}{l}-4.212 \\
(3.889)\end{array}$ \\
\hline GDP growth rate, lag & $\begin{array}{c}-0.0370^{* *} \\
(0.018)\end{array}$ & $\begin{array}{c}-0.0719^{* *} \\
(0.034)\end{array}$ & $\begin{array}{c}0.028 \\
(0.034)\end{array}$ & $\begin{array}{l}-0.192 * \\
(0.105)\end{array}$ & $\begin{array}{l}-0.005 \\
(0.027)\end{array}$ & $\begin{array}{l}-0.036 \\
(0.042)\end{array}$ \\
\hline Freedom index, civil liberty, lag & $\begin{array}{c}0.275^{* *} \\
(0.110)\end{array}$ & $\begin{array}{c}0.314 \\
(0.253)\end{array}$ & $\begin{array}{l}-0.345 \\
(0.281)\end{array}$ & $\begin{array}{l}-1.420 \\
(1.044)\end{array}$ & $\begin{array}{l}-0.166 \\
(0.203)\end{array}$ & $\begin{array}{l}-0.315 \\
(0.291)\end{array}$ \\
\hline \multicolumn{7}{|l|}{ Additional instruments } \\
\hline \# of years from the previous debt restuct. & & $\begin{array}{c}-0.211^{* * *} \\
(0.064)\end{array}$ & & $\begin{array}{c}-2.595 * * * \\
(0.748)\end{array}$ & & $\begin{array}{l}-0.083 \\
(0.072)\end{array}$ \\
\hline Legislative index of elecroral comp., lag & & $\begin{array}{c}0.280 \\
(0.253)\end{array}$ & & $\begin{array}{c}0.881 \\
(1.283)\end{array}$ & & $\begin{array}{l}-0.172 \\
(0.310)\end{array}$ \\
\hline Executive index of elecroral comp., lag & & $\begin{array}{c}-0.264 \\
(0.280)\end{array}$ & & $\begin{array}{c}0.018 \\
(0.669)\end{array}$ & & $\begin{array}{l}0.508^{*} \\
(0.272)\end{array}$ \\
\hline Coerciveness index, lag & & $\begin{array}{l}-0.170^{*} \\
(0.087)\end{array}$ & & $\begin{array}{c}0.075 \\
(0.296)\end{array}$ & & $\begin{array}{l}-0.049 \\
(0.116)\end{array}$ \\
\hline Country fixed effects & Yes & Yes & Yes & Yes & Yes & Yes \\
\hline \# of observations & 825 & 408 & 400 & 298 & 467 & 340 \\
\hline \# of countries & 49 & 20 & 49 & 20 & 49 & 20 \\
\hline Log likelihood ratio & 87.21 & 109.62 & 88.92 & 118.83 & 84.37 & 89.00 \\
\hline$(p$-value $)$ & 0.000 & 0.000 & 0.000 & 0.000 & 0.000 & 0.000 \\
\hline Pseudo $R$-squared & 0.25 & 0.54 & 0.46 & 0.78 & 0.35 & 0.50 \\
\hline ROC & 0.86 & 0.96 & 0.95 & 0.99 & 0.92 & 0.95 \\
\hline
\end{tabular}

Notes: All regressions include country fixed effects. The sample period is 1970-2013. *** ${ }^{* *}$, and * indicate statistical significance at 1 percent, 5 percent, and 10 percent level, respectively. Standard errors are in parentheses. Total number of past debt restructurings is used to predict post-default and weakly preemptive debt restructurings. Number of past debt

restructurings for the past six years is used predict "weakly and strictly" preemptive cases. 
Figure E8 and Table E7 report the AIPW estimates for GDP, investment, private credit, and net capital inflows with the enlarged set of instruments. The results show that our baseline AIPW estimates are robust (Table C2 in Appendix C.2); post-default restructurings experience a more severe and prolonged decline in GDP, investment, private credit, and net capital inflows than weakly preemptive restructurings.

Table E7: Estimation Results with Enlarged Set of Instruments, AIPW

\begin{tabular}{|c|c|c|c|c|c|c|}
\hline & $h=1$ & $h=2$ & $h=3$ & $h=4$ & $h=5$ & Sum \\
\hline Post-default & $-4.371 * * *$ & $-8.054 * * *$ & $-5.653 * * *$ & $-4.242 * * *$ & $-4.502 * * *$ & $-26.28 * * *$ \\
\hline & $(0.561)$ & $(0.810)$ & $(0.560)$ & $(0.627)$ & $(0.725)$ & $(2.858)$ \\
\hline \# of obs. & 400 & 400 & 400 & 400 & 386 & 386 \\
\hline \# of countries & 16 & 16 & 16 & 16 & 16 & 16 \\
\hline \# of debt restructuring obs. & 28 & 28 & 28 & 28 & 28 & 28 \\
\hline \multirow[t]{2}{*}{ Weakly preemptive } & $-1.503 * *$ & $-1.600^{*}$ & -0.523 & $-3.118 * * *$ & $-2.801 * *$ & $-9.544 * * *$ \\
\hline & $(0.762)$ & $(0.925)$ & $(1.026)$ & $(1.023)$ & $(1.206)$ & $(3.428)$ \\
\hline \# of obs. & 96 & 96 & 96 & 96 & 96 & 96 \\
\hline \# of countries & 11 & 11 & 11 & 11 & 11 & 11 \\
\hline \# of debt restructuring obs. & 21 & 21 & 21 & 21 & 21 & 21 \\
\hline \multirow[t]{2}{*}{ Weakly \& strictly preemptive } & $-2.646 * * *$ & $-1.291 * * *$ & 1.127 & -0.253 & $-2.997 * * *$ & $-5.861 *$ \\
\hline & $(0.304)$ & $(0.456)$ & $(0.744)$ & $(1.045)$ & $(1.053)$ & $(3.111)$ \\
\hline \# of obs. & 340 & 340 & 340 & 340 & 327 & 327 \\
\hline \# of countries & 13 & 13 & 13 & 13 & 13 & 13 \\
\hline \# of debt restructuring obs. & 25 & 25 & 25 & 25 & 25 & 25 \\
\hline \multicolumn{7}{|c|}{ Panel B: Dep. Var. $=100 \times\left(\right.$ Investment $_{i, t+h} / G D P_{i, t+h}-$ Investment $\left._{i, t} / G D P_{i, t}\right)$} \\
\hline & $h=1$ & $h=2$ & $h=3$ & $h=4$ & $h=5$ & Sum \\
\hline \multirow[t]{2}{*}{ Post-default } & $-0.891 * *$ & $-1.144 * * *$ & -0.334 & $1.088 * *$ & 0.775 & -0.240 \\
\hline & $(0.417)$ & $(0.443)$ & $(0.414)$ & $(0.465)$ & $(0.622)$ & $(2.256)$ \\
\hline \# of obs. & 397 & 397 & 397 & 397 & 383 & 383 \\
\hline \# of countries & 16 & 16 & 16 & 16 & 16 & 16 \\
\hline \# of debt restructuring obs. & 27 & 27 & 27 & 27 & 27 & 27 \\
\hline \multirow[t]{2}{*}{ Weakly preemptive } & 1.103 & 1.081 & 1.330 & $-1.258 * *$ & $-2.167 * * *$ & 0.089 \\
\hline & $(0.983)$ & $(0.983)$ & $(1.078)$ & $(0.596)$ & $(0.699)$ & $(3.247)$ \\
\hline \# of obs. & 92 & 92 & 92 & 92 & 92 & 92 \\
\hline \# of countries & 11 & 11 & 11 & 11 & 11 & 11 \\
\hline \# of debt restructuring obs. & 21 & 21 & 21 & 21 & 21 & 21 \\
\hline \multirow[t]{2}{*}{ Weakly \& strictly preemptive } & 0.613 & 1.157 & $1.226^{* * *}$ & $1.271 * *$ & $1.008^{*}$ & $5.456 * *$ \\
\hline & $(0.392)$ & $(0.464)$ & $(0.423)$ & $(0.516)$ & $(0.609)$ & $(2.159)$ \\
\hline \# of obs. & 340 & 340 & 340 & 340 & 327 & 327 \\
\hline \# of countries & 13 & 13 & 13 & 13 & 13 & 13 \\
\hline \# of debt restructuring obs. & 25 & 25 & 25 & 25 & 25 & 25 \\
\hline
\end{tabular}

Notes: The table shows local projections (AIPW) of the variables shown in each panel for $h=1,2, . ., 5$, where $h$ indicates horizon. All regressions include a constant term, lagged dependent variables (lag 1), cyclical component of log of GDP obtained from a HodrickPrescott filter with a smoothing parameter of 100 , and country fixed effects. Robust standard errors, clustered at the country-level, are in parentheses. ${ }^{* * *},{ }^{* *}$, and ${ }^{*}$ indicate statistical significance at 1 percent, 5 percent, and 10 percent level, respectively. 
Panel C: Dep. Var. $=100 \times\left(\right.$ Credit $_{i, t+h} / G D P_{i, t+h}-$ Credit $\left._{i, t} / G D P_{i, t}\right)$

\begin{tabular}{rcccccc}
\hline & $h=1$ & $h=2$ & $h=3$ & $h=4$ & $h=5$ & Sum \\
\hline Post-default & $-0.556^{* * *}$ & $-4.184^{* * *}$ & $-3.757^{* * *}$ & $-3.552^{* * *}$ & $-4.679^{* * *}$ & $-16.85^{* * *}$ \\
& $(0.222)$ & $(0.389)$ & $(0.404)$ & $(0.547)$ & $(0.558)$ & $(1.839)$ \\
\# of obs. & 378 & 378 & 378 & 378 & 365 & 365 \\
\# of countries & 15 & 15 & 15 & 15 & 15 & 15 \\
\# of debt restructuring obs. & 27 & 27 & 27 & 27 & 27 & 27 \\
\hline Weakly \& strictly preemptive & -0.182 & $-1.614^{* * *}$ & $-1.505^{* * *}$ & $-1.545^{* * *}$ & $-1.510^{* *}$ & $-6.512^{* * *}$ \\
& $(0.188)$ & $(0.287)$ & $(0.379)$ & $(0.534)$ & $(0.627)$ & $(1.816)$ \\
\# of obs. & 340 & 340 & 340 & 340 & 327 & 327 \\
\# of countries & 13 & 13 & 13 & 13 & 13 & 13 \\
\# of debt restructuring obs. & 25 & 25 & 25 & 25 & 25 & 25 \\
\hline Panel D: Dep. Var. $=100 \times\left(N C I_{i, t+h} / G D P_{i, t+h}-N C I_{i, t} / G D P_{i, t}\right)$ & \\
\hline Post-default & $h=1$ & $h=2$ & $h=3$ & $h=4$ & $h=5$ & Sum \\
\hline & $(1.067 * * *$ & $-7.391 * * *$ & 0.1705 & $2.310^{* *}$ & -1.533 & $-10.50^{* *}$ \\
\# of obs. & 393 & $(1.493)$ & $(1.111)$ & $(1.091)$ & $(1.020)$ & $(4.790)$ \\
\# of countries & 16 & 16 & 392 & 392 & 378 & 375 \\
\# of debt restructuring obs. & 28 & 28 & 28 & 16 & 16 & 16 \\
\hline Weakly preemptive & 0.174 & -0.138 & $-2.467^{*}$ & $-5.727^{* * *}$ & 0.425 & -6.188 \\
& $(1.164)$ & $(1.323)$ & $(1.369)$ & $(1.486)$ & $(1.587)$ & $(4.907)$ \\
\# of obs. & 96 & 95 & 94 & 94 & 94 & 92 \\
\# of countries & 11 & 11 & 11 & 11 & 11 & 11 \\
\# of debt restructuring obs. & 25 & 25 & 25 & 25 & 25 & 25 \\
\hline \# of obs. & 336 & 335 & 335 & 335 & 322 & 319 \\
\hline Weakly \& strictly preemptive & 0.238 & $3.822^{* * *}$ & $3.180^{* * *}$ & $2.527 * *$ & $5.481^{* * *}$ & $16.39 * * *$ \\
& $(0.782)$ & $(0.927)$ & $(0.867)$ & $(1.010)$ & $(1.167)$ & $(4.054)$ \\
\hline
\end{tabular}

Notes: The table shows local projections (AIPW) of the variables shown in each panel for $h=1,2, \ldots, 5$, where $h$ indicates horizon. All regressions include a constant term, lagged dependent variables (lag 1), cyclical component of log of GDP obtained from a HodrickPrescott filter with a smoothing parameter of 100 , and country fixed effects. Robust standard errors, clustered at the country-level, are in parentheses. ${ }^{* \star *},{ }^{* *}$, and ${ }^{*}$ indicate statistical significance at 1 percent, 5 percent, and 10 percent level, respectively.

Figure E8: Local Projections with the Enlarged Set of Instruments, AIPW
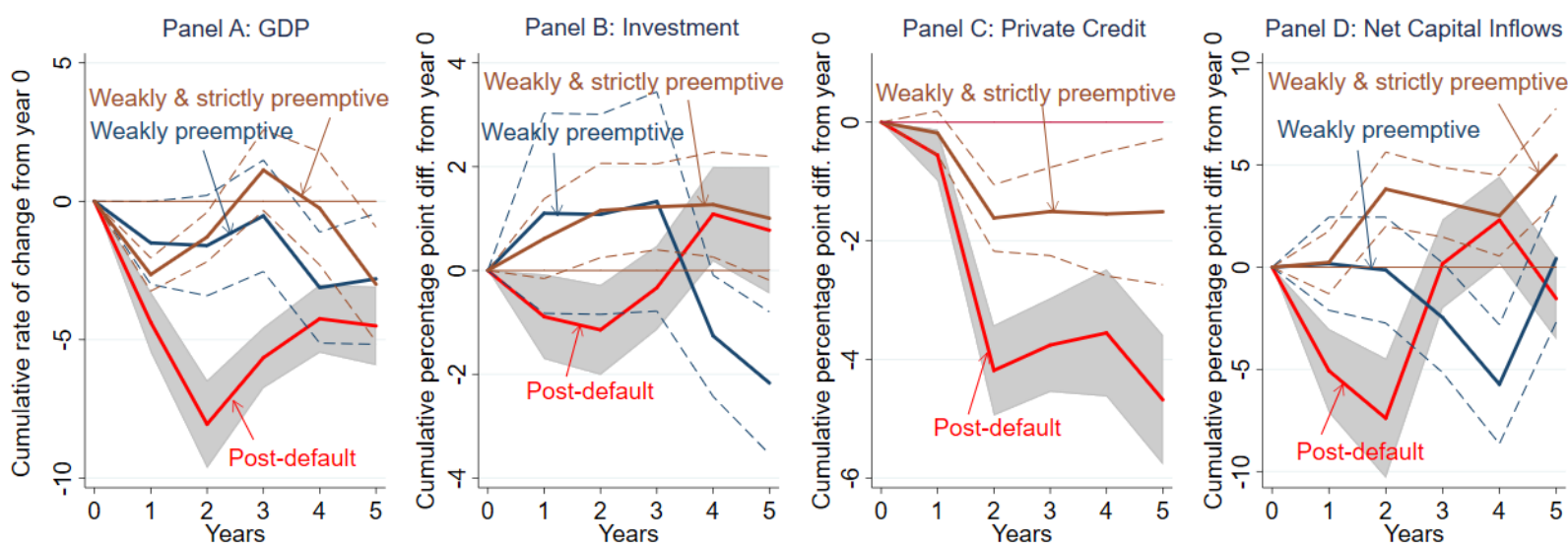

The figure shows local projections (with enlarged set of instruments) of the variables shown in each panel for $h=1,2, \ldots, 5$, where $h$ indicates horizon. Solid lines in red, blue and brown are point estimates. Gray Bands and dotted lines in blue and brown are 95 percent confidence intervals. The sample period is 1970-2013. 
Second, we apply the AIPW estimation with GDP projections included as an additional control. The data on GDP forecasts are available from the IMF WEO over the period 1990-2013 at an annual frequency. We include the variable as additional instrument in both the first-stage and second-stage regressions. The estimation is specified as follows:

$$
\begin{gathered}
g_{i, t+h}=\alpha_{i}^{h}+\Lambda^{P D, h} D_{i, t+1}^{P D}+\beta^{\text {Forecast }} g_{i, t}^{\text {Forecast }}+\boldsymbol{X}_{i, t} \boldsymbol{\beta}^{R . h}+\epsilon_{i, t+h}^{R}, \\
h=1,2, \ldots, 5
\end{gathered}
$$

where $g_{i, t}^{\text {Forecast }}$ denotes the GDP growth rate forecasts defined as $g_{i, t}^{\text {Forecast }}=\sum_{s=1}^{5} g_{i, t}^{\text {Forecast }, t+s} /$ 5 , which is the average of GDP growth rate forecasts over the next five years in pre-restructuring year $t$. With limited sample of the GDP forecasts, our sample of restructurings is significantly reduced in this estimation. To be comparable with this estimation, we also estimate our baseline specification (equation 2 without GDP growth forecasts) with the same sample as in equation (E.1). Results are reported in Figure E9 and Table E8. These show that our baseline results for post-default restructurings are robust when we control for the GDP forecasts.

Figure E9: GDP after Post-default Restructurings Controlling for GDP Forecasts, AIPW

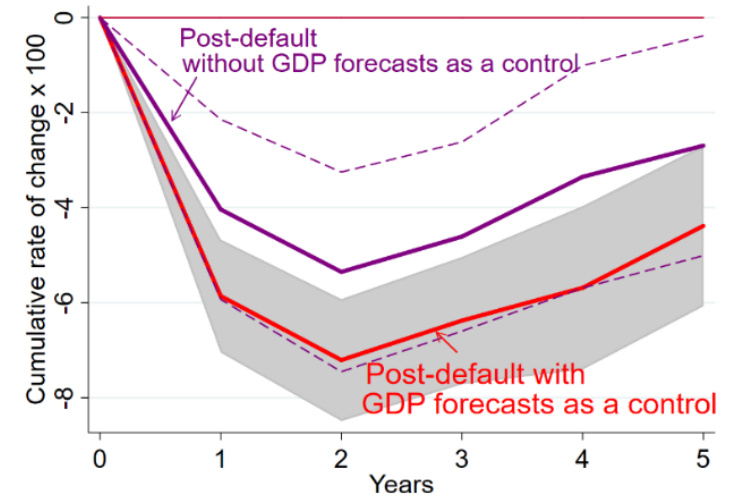

The figure shows local projections (with enlarged set of instruments including GDP forecasts) of GDP shown in each panel for $h=1,2, \ldots, 5$, where $h$ indicates horizon. Solid lines in red and purple are point estimates. Gray Bands and dotted lines in purple are 95 percent confidence intervals. The sample period is 1990-2013.

Table E8: Estimation Results Controlling for GDP Forecasts, AIPW

\begin{tabular}{rcccccc}
\multicolumn{7}{c}{ Dep. Var. $=100 \times\left(G D P_{i, t+h}-G D P_{i, t}\right) / G D P_{i, t}$} \\
\hline & $h=1$ & $h=2$ & $h=3$ & $h=4$ & $h=5$ & Sum \\
\hline \# of obs. & 145 & 145 & 145 & 145 & 138 & 138 \\
\# of countries & 8 & 8 & 8 & 8 & 8 & 8 \\
\# of debt restructuring obs. & 9 & 9 & 9 & 9 & 9 & 9 \\
\hline Post-default, with GDP forecasts & $-5.858^{* * *}$ & $-7.205^{* * *}$ & $-6.374^{* * *}$ & $-5.685^{* * *}$ & $-4.382^{* * * *}$ & $-28.26^{* * *}$ \\
\# of obs. & 145 & $(0.654)$ & $(0.683)$ & $(0.877)$ & $(0.863)$ & $(3.304)$ \\
\# of countries & 8 & 8 & 8 & 8 & 8 & 8 \\
\# of debt restructuring obs. & 9 & 9 & 9 & 9 & 9 & 9 \\
\hline
\end{tabular}

Notes: The table show local projections (AIPW) of GDP for $h=1,2, \ldots, 5$, where $h$ indicates horizon. All regressions include a constant term, lagged dependent variables (lag 1), cyclical component of log of GDP obtained from a HodrickPrescott filter with a smoothing parameter of 100 , and country fixed effects. Robust standard errors, clustered at the country-level, are in parentheses. ${ }^{* *},{ }^{* *}$, and ${ }^{*}$ indicate statistical significance at 1 percent, 5 percent, and 10 percent level, respectively. The estimates are based on the same sample of restructuring observations. 


\section{E.7. Consumer Price Index (CPI) Inflation Rates}

Panel A and B in Figure E10 report the dynamics of year-to-year consumer price index (CPI) inflation rates. We follow the same presentation as in Figure 4 in terms of both the classification by restructuring strategies and normalization at the pre-crisis $(t=0)$ level. For each restructuring strategy, we differentiate non-hyperinflationary from hyperinflationary periods. Following Reinhart and Rogoff (2011b), hyperinflationary periods are defined as episodes where the yearto-year inflation rate exceeds 500 percent, as reported in Table E9. Without hyperinflations, CPI inflation rate experiences a sharp rise following a post-default restructuring (red line in Panel B). A moderate rise in CPI inflation rate occurs in the run-up to a weakly preemptive restructuring (blue line in Panel B). In contrast, CPI inflation experiences a much smaller and short-lived rise followed by recovery to its pre-crisis level (green line in Panel B). In any of three strategies, adjustments through CPI inflation rate seem to be smaller than those in domestic default episodes as discussed in Reinhart and Rogoff (2009).

Panel C in Figure E10 reports the cumulative responses for CPI inflation rate. We follow the same presentation as in Figure 7 in terms of both the classification by restructuring strategies and normalization at the pre-crisis $(\mathrm{t}=0)$ level. Focusing on non-hyperinflation episodes, postdefault restructurings experience a shaper rise in CPI inflation rate than weakly or strictly preemptive restructurings (red line in Panel C).

Figure E10: CPI Inflation Rates, year-to-year
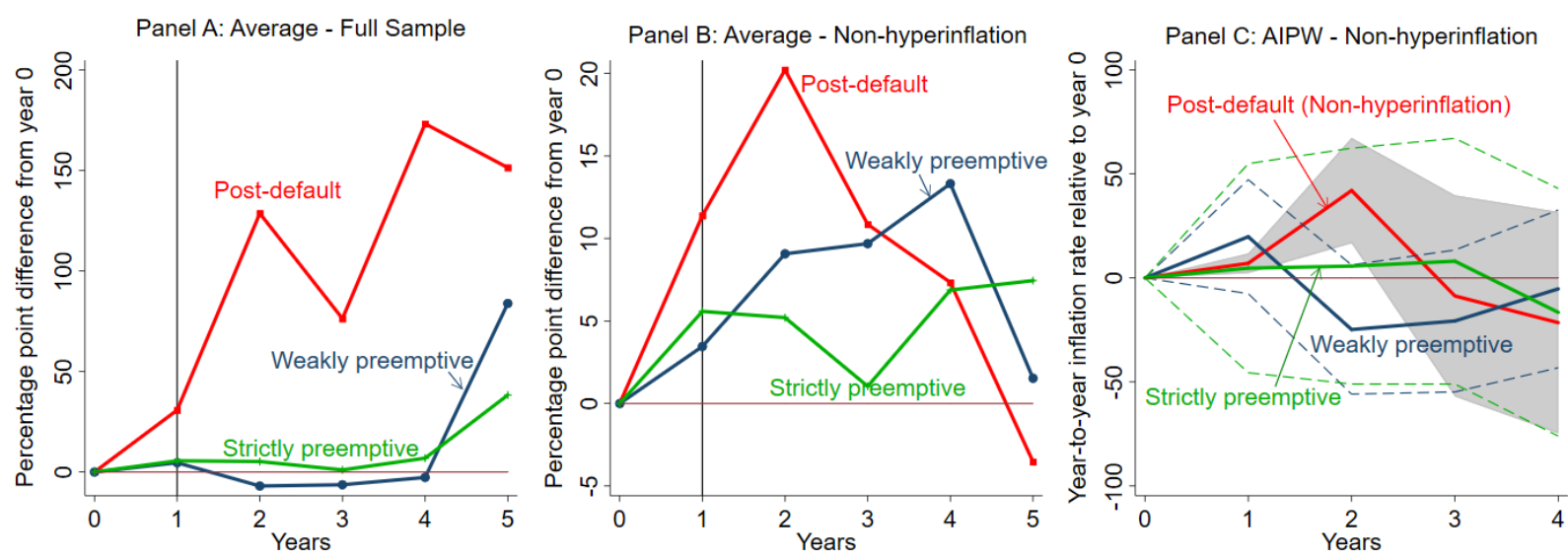

CPI inflation data come from WDI. Following Reinhart and Rogoff (2011b), hyperinflations are defined as episodes where the annual inflation rate exceeds 500 percent. Panel C shows local projections of CPI inflation rates for $h=1,2, \ldots, 5$, where $h$ indicates horizon. Solid lines in red, blue and brown are point estimates. Gray Bands and dotted lines in blue and brown are 95 percent confidence intervals. The sample period is $1970-2013$. 
Table E9: Average CPI Inflation Rates, year-to-year

Panel A: Post-default Restructurings

\begin{tabular}{|c|c|c|c|c|c|c|}
\hline & $h=0$ & $h=1$ & $h=2$ & $h=3$ & $h=4$ & $h=5$ \\
\hline & \multicolumn{6}{|c|}{ Full Sample } \\
\hline Average inflation rate & 34.01 & 64.81 & 162.66 & 110.31 & 207.24 & 185.37 \\
\hline Standard deviation & 80.75 & 188.31 & 523.91 & 313.47 & 1159.91 & 677.25 \\
\hline \multirow[t]{2}{*}{ Sample size } & 71 & 71 & 73 & 77 & 79 & 79 \\
\hline & \multicolumn{6}{|c|}{ Hyperinflation Sample } \\
\hline Average inflation rate & 629.11 & 1027.86 & 1752.87 & 985.29 & 2788.20 & 1865.94 \\
\hline Standard deviation & & 569.73 & 1207.72 & 666.82 & 4157.56 & 1528.38 \\
\hline \multirow[t]{2}{*}{ Sample size } & 1 & 2 & 5 & 6 & 5 & 7 \\
\hline & \multicolumn{6}{|c|}{ Non-Hyperinflation Sample } \\
\hline Average inflation rate & 25.51 & 36.90 & 45.73 & 36.37 & 32.85 & 21.99 \\
\hline Standard deviation & 37.54 & 60.51 & 72.73 & 61.28 & 57.55 & 30.91 \\
\hline Sample size & 70 & 69 & 68 & 71 & 74 & 72 \\
\hline \multicolumn{7}{|c|}{ Panel B: Weakly Preemptive Restructurings } \\
\hline & $h=0$ & $h=1$ & $h=2$ & $h=3$ & $h=4$ & $h=5$ \\
\hline & \multicolumn{6}{|c|}{ Full Sample } \\
\hline Average inflation rate & 49.56 & 54.16 & 42.60 & 43.22 & 46.85 & 133.40 \\
\hline Standard deviation & 105.25 & 113.73 & 55.10 & 59.22 & 76.79 & 509.56 \\
\hline \multirow[t]{2}{*}{ Sample size } & 37 & 37 & 37 & 37 & 37 & 37 \\
\hline & \multicolumn{6}{|c|}{ Hyperinflation Sample } \\
\hline Average inflation rate & 626.72 & 672.18 & NA & NA & NA & 1854.46 \\
\hline Standard deviation & NA & NA & NA & NA & NA & 1732.90 \\
\hline \multirow[t]{2}{*}{ Sample size } & 1 & 1 & 0 & 0 & 0 & 2 \\
\hline & \multicolumn{6}{|c|}{ Non-Hyperinflation Sample } \\
\hline Average inflation rate & 33.53 & 36.99 & 42.60 & 43.22 & 46.85 & 35.06 \\
\hline Standard deviation & 40.16 & 45.70 & 55.10 & 59.22 & 76.79 & 49.03 \\
\hline Sample size & 36 & 36 & 37 & 37 & 37 & 35 \\
\hline \multicolumn{7}{|c|}{ Panel C: Strictly Preemptive Restructurings } \\
\hline & $h=0$ & $h=1$ & $h=2$ & $h=3$ & $h=4$ & $h=5$ \\
\hline & \multicolumn{6}{|c|}{ Full Sample } \\
\hline Average inflation rate & 27.07 & 32.65 & 32.27 & 28.11 & 33.94 & 65.32 \\
\hline Standard deviation & 23.68 & 30.87 & 30.85 & 26.39 & 50.13 & 150.39 \\
\hline \multirow[t]{2}{*}{ Sample size } & 21 & 21 & 21 & 21 & 21 & 21 \\
\hline & \multicolumn{6}{|c|}{ Hyperinflation Sample } \\
\hline Average inflation rate & NA & NA & NA & NA & NA & 681.42 \\
\hline Standard deviation & NA & NA & NA & NA & NA & NA \\
\hline \multirow[t]{2}{*}{ Sample size } & 0 & 0 & 0 & 0 & 0 & 1 \\
\hline & \multicolumn{6}{|c|}{ Non-Hyperinflation Sample } \\
\hline Average inflation rate & 27.07 & 32.65 & 32.27 & 28.11 & 33.94 & 34.51 \\
\hline Standard deviation & 23.68 & 30.87 & 30.85 & 26.39 & 50.13 & 53.20 \\
\hline Sample size & 21 & 21 & 21 & 21 & 21 & 20 \\
\hline
\end{tabular}

Notes: The data come from WDI. Hyperinflations are defined as year-to-year inflation rates greater than 500 percent. $h$ indicates horizon. A smaller number of observations at $h=0$ than that at $h=4,5$ in Panel A is due to an unbalanced panel of CPI inflation rates-the first year when CPI inflation rate data are available differs across sample countries. 